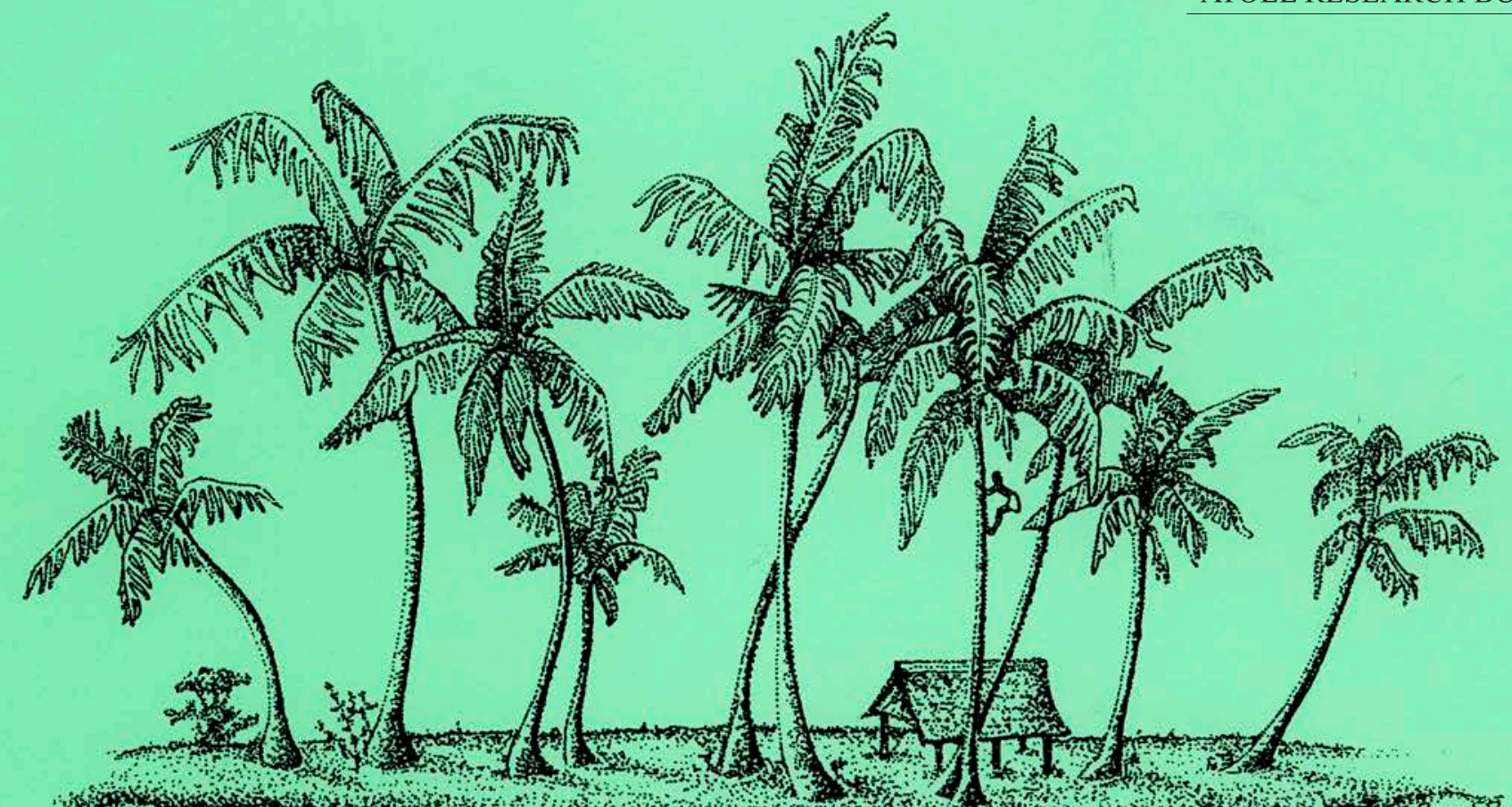

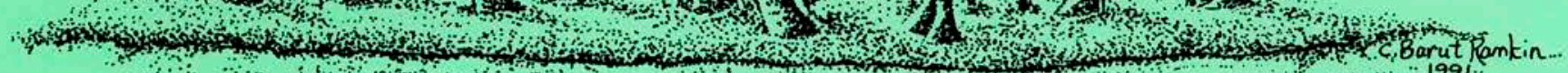
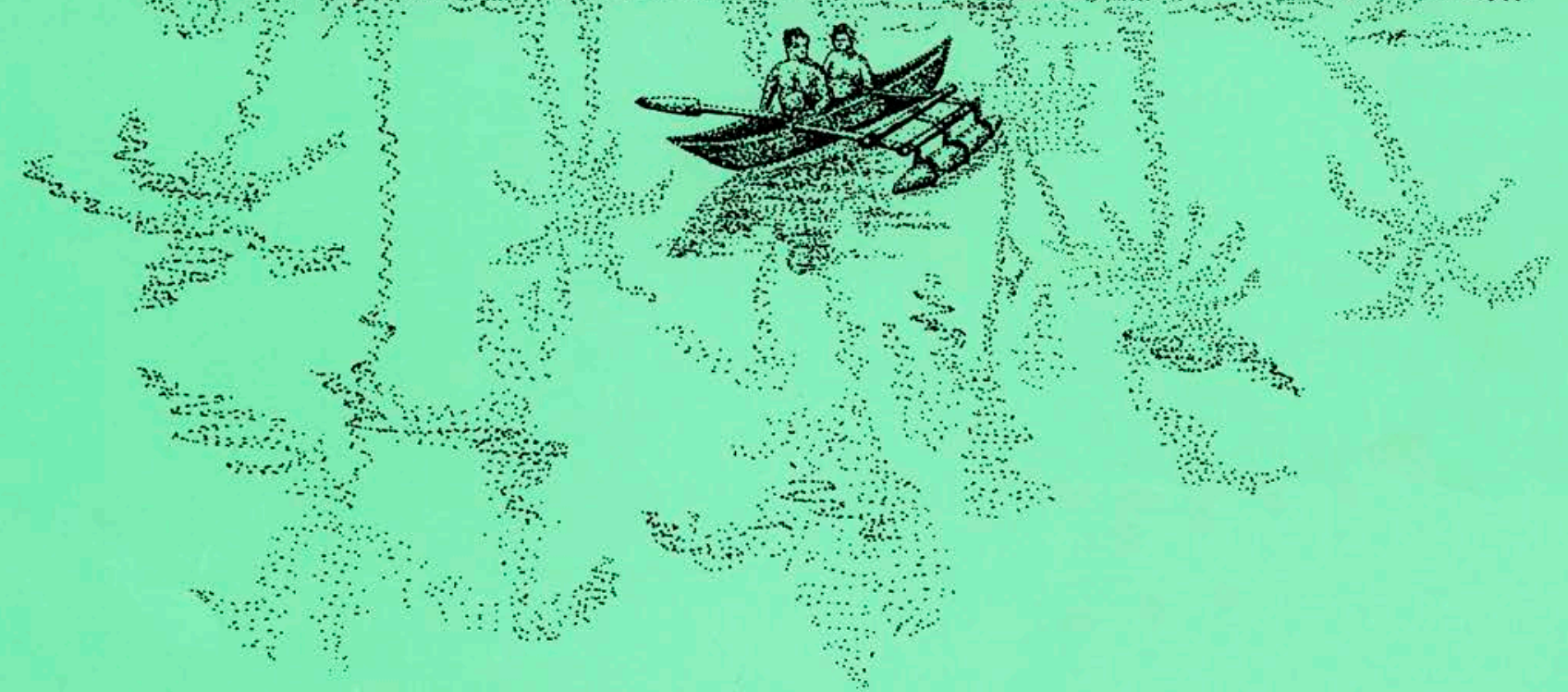

THE FLORA OF TUVALU:

LAKAU MO MOUKU O TUVALU

R. R. Thaman

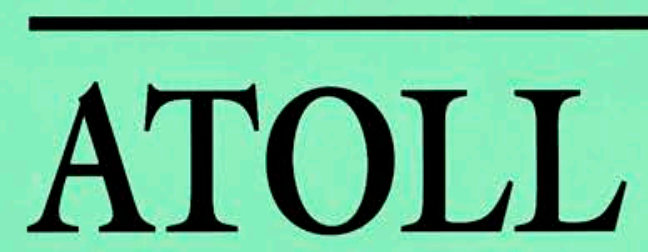

RESEARCH 


\section{THE FLORA OF TUVALU: LAKAU MO MOUKU O TUVALU}

R. R. Thaman

Atoll Research Bulletin No. 611 17 October 2016

Smithsonian Institution Scholarly Press

Washington, D.C. 
All statements made in papers published in the Atoll Research Bulletin are the sole responsibility of the authors and do not necessarily represent the views of the Smithsonian Institution or of the editors of the bulletin. Articles submitted for publication in the Atoll Research Bulletin should be original papers and must be made available by authors for open access publication. Manuscripts should be consistent with the "Author Formatting Guidelines for Publication in the Atoll Research Bulletin." All submissions to the bulletin are peer reviewed and, after revision, are evaluated prior to acceptance and publication through the publisher's open access portal, Open SI

(http://opensi.si.edu).

Published by SMITHSONIAN INSTITUTION SCHOLARLY PRESS

P.O. Box 37012, MRC 957

Washington, D.C. 20013-7012

www.scholarlypress.si.edu

The rights to all text and images in this publication are owned either by the contributing authors or third parties. Fair use of materials is permitted for personal, educational, or noncommercial purposes. Users must cite author and source of content, must not alter or modify the content, and must comply with all other terms or restrictions that may be applicable. Users are responsible for securing permission from a rights holder for any other use.

ISSN: 0077-5630 (online) 


\section{CONTENTS}

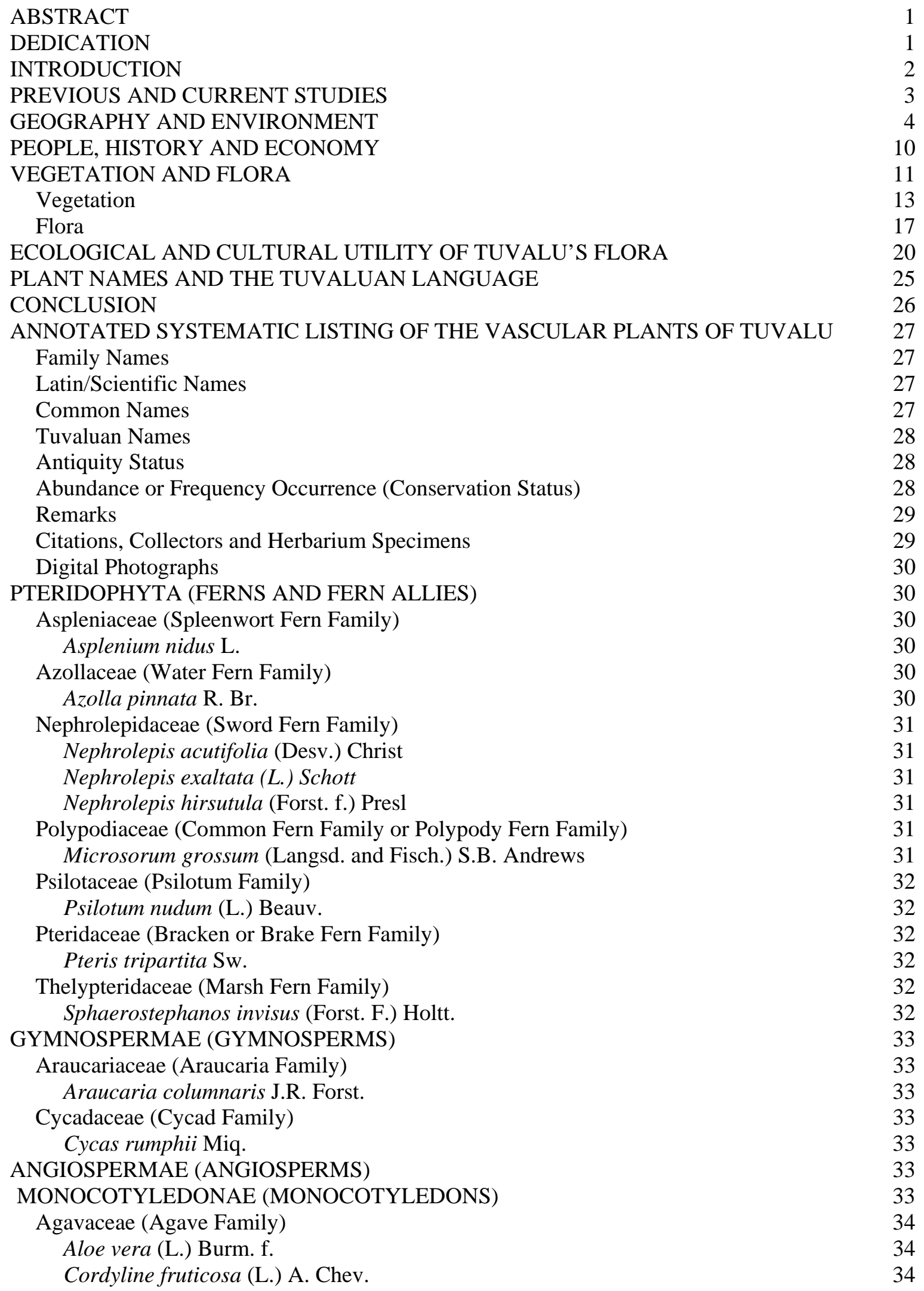


Dracaena angustifolia Roxburg 34

Dracaena fragrans (L.) Ker-Gawl.

Dracaena sanderiana Sander ex Mast.

Sansevieria trifasciata Prain 35

Alliaceae (Onion Family) 35

Allium fistulosum L.

Allium sativum L.

Allium schoenoprasum L.

Allium tuberosum Rottler ex. Sprengle $\quad 36$

Amaryllidaceae (Amaryllis Lily Family) 36

Crinum asiaticum L. 36

Crinum augustum Roxb. 36

Crinum xanthophyllum Hannibal 36

Crinum zeylanicum L. 37

Hippeastrum puniceum (Lam.) Urban 37

Hymenocallis pedalis (Jacq.) Herbert 37

Proiphys amboinensis (L.) Herbert 37

Zephyranthes rosea (Lindl.) Green $\quad 37$

Araceae (Arum or Taro Family) 38

Aglaonema commutatum Schott 38

Alocasia macrorrhizos (L.) G. Don 38

Alocasia sanderiana Bull. x “Amazonica” 38

Caladium bicolor (Ait.) Vent. 38

Colocasia esculenta L. 39

Cyrtosperma chamissonis (Schott) Merr. $\quad 39$

Dieffenbachia maculata (Lodd.) Bunt. $\quad 40$

Epipremnum pinnatum (L.) Engler 40

Philodendron sp. $\quad 40$

Philodendron scandens C. Koch \& Sellow ssp. oxicardium (Schott) Bunt. 40

Spathiphyllum cv. Clevelandii $\quad 40$

Syngonium podophyllum Schott $\quad 40$

Xanthosoma brasiliense (Desf.) Engler $\quad 41$

Xanthosoma sagittifolium (L.) Schott 41

Xanthosoma violaceum Schott 41

Arecaceae or Palmae (Palm Family) 41

Chrysalidocarpus lutescens H. Wendl.

Cocos nucifera L. $\quad 41$

Pritchardia pacifica Seem. \& Wendl. 42

Ptychosperma macarthuri (Wendl.) Nicholson 42

Bromeliaceae (Pineapple Family) 43

Ananas comosus (L.) Merrill 43

Cannaceae (Canna Family) 43

Canna indica L. 43

Canna x generalis L.H. Bailey 43

Commelinaceae (Dayflower or Spiderwort Family) 43

Callisia fragrans (Lindl.) Woodson 43

Commelina diffusa Burm. f.

Tradescantia pallida (Rose) D. Hunt 44

Tradescantia spathacea Swartz 44

Tradescantia zebrina Bosse $\quad 44$

Cyperaceae (Sedge Family) 44 
Cyperus compressus L. $\quad 44$

Cyperus involucratus Rottb. $\quad 44$

Cyperus odoratus L. $\quad 45$

Cyperus rotundus L. $\quad 45$

Eleocharis geniculata (L.) Roem. \& Schultes 45

Fimbristylis cymosa R. Br. $\quad 45$

Fimbristylis dichotoma (L.) Vahl. 46

Kyllinga brevifolia Rottb. 46

Kyllinga nemoralis (Forst.) Dandy ex Hutchinson and Dalziel 46

Mariscus javanicus (Houtt.) Merr. 46

Pycreus polystachyos (Rottb.) P. Baeuv. 46

Dioscoreaceae (Yam Family) 47

Dioscorea alata L. $\quad 47$

Dioscorea nummularia Lam. 47

Heliconiaceae (Heliconia Family) 47

Heliconia collinsiana R.F. Griggs $\quad 47$

Iridaceae (Iris Family) $\quad 47$

Trimezia martinicensis (Jacq.) Herbert $\quad 47$

Liliaceae (Lily Family) $\quad 48$

Asparagus officinalis L. $\quad 48$

Chlorophytum comosum (Thunb.) Jacq. $\quad 48$

Gloriosa superba L. $\quad 48$

Musaceae (Banana Family) 48

Musa (AAA Group) Simmonds - “Robusta banana, poyo, Mons Marie, Veimama” 48

Musa (AAA Group) Simmonds - "dwarf Cavendish banana” 49

Musa (AB Group) Simmonds - "lady's finger banana, pisang rajah” 49

Musa (ABB Group) Simmonds - “cooking banana, plantain, bluggoe” 49

Musa (ABB Group) Simmonds - “cooking banana, ash plantain, blue Java” 49

Musa cultivars $\quad 50$

Orchidaceae (Orchid Family) $\quad 50$

Papilionanthe “Agnes Joaquim” 50

Vanilla planifolia Jacks. Ex Andrews $\quad 50$

Pandanaceae (Pandanus Family) $\quad 50$

Pandanus tectorius Warb. $\quad 50$

Poaceae or Graminae (Grass Family)

Axonopus compressus (Sw.) Beauv.

Bothriochloa bladhii (Retz.) S.T. Blake 51

Brachiaria subquadripara (Trin.) Hitchc. 52

Cenchrus echinatus L. 52

Chloris barbata (L.) Sw.

Cymbopogon citratus (DC. ex Nees) Staph 52

Cynodon dactylon (L.) Pers.

Dactyloctenium aegyptium (L.) Beauv. 53

Digitaria ciliaris (Retz.) Koel.

Digitaria radicosa (J.S. Presl) Miq.

Digitaria setigera Rot 53

Echinochloa colona (L.) Link.

Eleusine indica (L.) Gaertn. $\quad 54$

Eragrostis tenella (L.) Beauv. ex Roem. \& Schult.

Ischaemum murinum G. Forst.

Lepturopetium kuniense Morat. 54 
Lepturus repens (Forst. f.) R. Br.

Paspalum setaceum Michx.

Paspalum vaginatum Sw.

Saccharum officinarum L.

Schizostachym glaucifolium (Rupr.) Munro 55

Sporobolus fertilis (Steud.) Clayton 56

Stenotaphrum micranthum (Desv.) Hubb. 56

Thuarea involuta (Forst. f.) R. Br. ex R. \& S. 56

Zea mays L. $\quad 56$

Taccaceae (Polynesian Arrowroot Family) 57

Tacca leontopetaloides (L.) O. Kuntze $\quad 57$

Zingiberaceae (Ginger Family)

Alpinia purpurata (Vieill.) K. Schum.

Alpinia vittata Bull $\quad 57$

Costus malortianus H. Wend.

Costus speciosus (Koen.) Sm.

Costus woodsonii Maas 58

Zingiber officinale Roscoe 58

DICOTYLEDONAE (DICOTYLEDONS) 58

Acanthaceae (Acanthus Family) 58

Asystasia salicifolia Craib $\quad 58$

Hemigraphis alternata (Burm. f.) T. Anders. 58

Odontonema tubiforme (Bertol.) O. Ktze. 58

Pseuderanthemum carruthersii (Seem.) Guill. var. atropurpureum (Bull) Fosb. $\quad 59$

Pseuderanthemum carruthersii (Seem.) Guill. var. carruthersii 59

Pseuderanthemum carruthersii (Seem.) Guill. var. reticulatum (Bull) Fosb. 59

Ruellia prostrata Poiret $\quad 59$

Thunbergia erecta (Bentham) T. Anders. $\quad 60$

$\begin{array}{ll}\text { Amaranthaceae (Amaranth Family) } & 60\end{array}$

$\begin{array}{ll}\text { Achyranthes aspera L. } & 60\end{array}$

Achyranthes canescens R. Br. $\quad 60$

Alternanthera brasiliana (L.) Kuntze $\quad 60$

Alternanthera sessilis (L.) R. Br. ex R. \& S. $\quad 61$

Alternanthera sissoo Hort. $\quad 61$

Alternanthera tenella Colla $\quad 61$

Amaranthus hypochondriacus L. $\quad 61$

Amaranthus tricolor L. $\quad 61$

Amaranthus viridis L. $\quad 62$

Celosia argentea L. var. cristata (L.) Ktze. $\quad 62$

Gomphrena globosa L. $\quad 62$

Anacardiaceae (Cashew or Rhus Family) $\quad 62$

Mangifera indica L. $\quad 62$

Annonaceae (Custard Apple Family) 63

Annona muricata L. $\quad 63$

Annona squamosa L. 63

Apiaceae (Celery/Carrot Family) 63

Apium graveolens L. $\quad 63$

Centella asiatica (L.) Urban 63

Coriandrum sativum L. 63

Daucus carota L. $\quad 64$

Apocynaceae (Dog-Bane Family) 64 
Catharanthus roseus (L.) G. Don 64

Nerium oleander L. $\quad 64$

Ochrosia oppositifolia (Lam.) K. Schum.

Plumeria obtusa L. $\quad 65$

Plumeria rubra L. $\quad 65$

Tabernaemontana divaricata (L.) R. Br.

Araliaceae (Panax Family) $\quad 65$

Polyscias filicifolia (C. Moore ex. Fourn.) L. H. Bailey 65

Polyscias fruticosa (L.) Harms 66

Polyscias guilfoylei (Cogn. \& March.) Bailey 66

Polyscias scutellaria (Burm. f.) Fosb. $\quad 66$

Asclepiadaceae (Milkweed Family) 66

Asclepias curassavica L. $\quad 66$

Asteraceae (Aster, Sunflower or Daisy Family) 67

Adenostemma lanceolatum Miq. $\quad 67$

Bidens alba (L.) DC. $\quad 67$

Cyanthillium cinereum (L.) H. Rob 67

$\begin{array}{ll}\text { Eclipta prostrata (L.) L. } & 67\end{array}$

Emilia fosbergii Nicholson $\quad 68$

Gynura bicolor (Roxb. ex Willd.) DC 68

Lactuca sativa L. vars. $\quad 68$

Mikania micrantha Kunth 68

Pluchea carolinensis (Jacq.) G. Don 68

Pluchea indica (L.) Less. $\quad 68$

Senecio chenopodioides HBK $\quad 69$

Sphagneticola trilobata (L. C. Rich) Pruski. $\quad 69$

Synedrella nodiflora (L.) Gaertn. $\quad 69$

Tagetes erecta L. $\quad 69$

$\begin{array}{ll}\text { Tridax procumbens L. } & 70\end{array}$

Wollastonia biflora (L.) DC. $\quad 70$

$\begin{array}{ll}\text { Zinnia elegans Jacq. } & 70\end{array}$

Balsaminaceae (Balsam Family) $\quad 70$

Impatiens balsamina L. $\quad 70$

Barringtoniaceae or Lecythidaceae (Brazilnut Family) $\quad 71$

Barringtonia asiatica (L.) Kurz. $\quad 71$

$\begin{array}{ll}\text { Basellaceae (Basella Family) } & 71\end{array}$

Basella rubra L. $\quad 71$

Begoniaceae (Begonia Family) $\quad 71$

Begonia sp. $\quad 71$

Bignoniaceae (Bignonia Family) $\quad 71$

Tecoma stans (L.) Juss. ex HBK.

Boraginaceae (Heliotrope Family)

Cordia sebestena L.

Cordia subcordata Lam. $\quad 72$

Tournefortia argentea L. f.

Brassicaceae or Cruciferae (Cabbage or Mustard Family)

Brassica chinensis L. var. chinensis 73

Brassica chinensis L. var. parachinensis (Bailey) Tsen and Lee 73

Brassica juncea (L.) Czern.

Brassica oleracea L. Acephala Group $\quad 74$

Brassica oleracea L. var. botrytis L. 
Brassica oleracea L. var. capitata L. $\quad 74$

Brassica x hybridus "Saladeer"

Eruca sativa Mill.

Rorippa sarmentosa (G. Forst. Ex DC.) Macbride $\quad 74$

Cactaceae (Cactus Family)

Hylocereus undatus (Haw.) Britt. and Rose 75

Opuntia sp.

Capparidaceae or Capparaceae (Caper Family) 75

Cleome rutidosperma DC.

Cleome viscosa L.

Crateva religiosa Forst. f. $\quad 76$

Caricaceae (Papaya Family) $\quad 76$

Carica papaya L. $\quad 76$

Casuarinaceae (Casuarina Family)

Casuarina equisetifolia L. 76

Clusiaceae (Mangosteen Family) $\quad 76$

Calophyllum inophyllum L. $\quad 76$

Combretaceae (Terminalia Family)

Lumnitzera littorea (Jack) Voigt

Terminalia catappa L. $\quad 77$

Terminalia samoensis Rech.

$\begin{array}{ll}\text { Convolvulaceae (Morning-Glory Family) } & 78\end{array}$

Ipomoea aquatica Forsk. $\quad 78$

$\begin{array}{ll}\text { Ipomoea batatas (L.) Lam. } & 78\end{array}$

Ipomoea macrantha R. \& S. $\quad 79$

Ipomoea pes-caprae (L.) Sweet $\quad 79$

Ipomoea triloba L.

Cucurbitaceae (Melon or Gourd Family) $\quad 80$

Benicasa hispida (Thunb.) Cogn. 80

Citrullus lanatus (Thunb.) Matsum. and Nakai $\quad 80$

Cucumis melo L. variety $\quad 80$

$\begin{array}{lr}\text { Cucumis melo L. var. cantalupensis Naud } & 80\end{array}$

Cucumis melo L. var. conomon Makino $\quad 80$

Cucumis sativus L. $\quad 81$

$\begin{array}{ll}\text { Cucurbita cultivar } & 81\end{array}$

Cucurbita maxima Duch. variety $\quad 81$

Cucurbita moschata Duchesne ex Poir. $\quad 81$

Lagenaria siceraria L. $\quad 81$

Luffa acutangula (L.) Roxb. $\quad 82$

Luffa cylindrica (L.) Roem.

Momordica charantia L. $\quad 82$

Euphorbiaceae (Spurge Family) 82

Acalypha grandis Benth.

Acalypha hispida Burm. f. 83

Acalypha wilkesiana Muell.-Arg. var. wilkesiana 83

Acalypha wilkesiana Roxb. f. circinata Muell.-Arg. 83

Chamaesyce atoto (Forst. f) Croizat 83

Chamaesyce hirta (L.) Millsp. 83

Chamaesyce hypericifolia (L.) Millsp.

Chamaesyce prostrata (Ait.) Small $\quad 84$

Chamaesyce thymifolia (L.) Millsp. 
Cnidoscolus chayamansa McVaugh $\quad 84$

Codiaeum variegatum (L.) Bl.

Euphorbia cyathophora Murr. $\quad 85$

Euphorbia heterophylla L. 85

Euphorbia milii Desmoulins

Euphorbia sp. $\quad 85$

Jatropha integerrima Jacq.

Manihot esculenta Crantz 86

Pedilanthus tithymaloides (L.) Poit. 86

Phyllanthus acidus (L.) Skeels 86

Phyllanthus amarus Sch. \& Th. 86

Phyllanthus debilis Klein ex Willd.

Phyllanthus urinaria L. $\quad 87$

Ricinus communis L. $\quad 87$

Sauropus androgynus Merr. $\quad 87$

Fabaceae or Leguminosae (Bean, Pea, or Legume Family) 87

Acacia farnesiana (L.) Willd. $\quad 87$

Adenanthera pavonina L. $\quad 88$

Alysicarpus vaginalis (L.) DC.

Bauhinia sp. $\quad 88$

Caesalpinia bonduc (L.) Roxb. 88

Caesalpinia pulcherrima (L.) Swartz 88

Cajanus scarabaeoides (L.) Thouars.

Canavalia cathartica Thou. $\quad 89$

Clitorea ternatea L. $\quad 89$

Crotalaria pallida L. $\quad 89$

Delonix regia (Bojer) Raf. $\quad 90$

Desmodium heterophyllum (Willd.) DC. 90

Desmodium incanum DC. $\quad 90$

Leucaena leucocephala (Lam.) de Wit 90

Macroptilium atropurpureum (DC.) Urb. 90

Macroptilium lathyroides (L.) Urb. $\quad 91$

Mimosa pudica L. $\quad 91$

Mucuna gigantea (Willd.) DC.

Phaseolus vulgaris L. $\quad 91$

Samanea saman (Jacq.) Merr. $\quad 91$

Senna occidentalis (L.) Link 92

Senna tora (L.) Roxb. $\quad 92$

Sesbania cannabina (Retz.) Pers. $\quad 92$

Sesbania grandiflora (L.) Pers.

Sophora tomentosa L. $\quad 92$

Tamarindus indicus L. $\quad 93$

Vigna marina (Burm.) Merr. 93

Vigna sesquipedalis (L.) Fruw.

Vigna unguiculata (L.) Walp.

Gesneriaceae (Gloxinia Family) 94

Chrysothemis pulchella (Donn ex Simms) Decaisne 94

Goodeniaceae (Naupaka Family) 94

Scaevola taccada (Gaertn.) Roxb. $\quad 94$

Hernandiaceae (Hernandia Family) 94

Hernandia nymphaeifolia (Presl.) Kubitzki 94 
Lamiaceae (Mint Family) $\quad 95$

Mentha piperita L. $\quad 95$

Ocimum basilicum L. $\quad 95$

Ocimum tenuiflorum L. 95

Plectranthus amboinicus (Lour.) Spreng.

Plectranthus scutellarioides (L.) R. Br. 96

Lauraceae (Laurel Family) 96

Cassytha filiformis L. $\quad 96$

Persea americana Mill. $\quad 96$

Lythraceae (Loosestrife Family) 96

Pemphis acidula J.R. Forst. \& G. Forst. 96

Malpighiaceae (Malphigia Family) 97

Malpighia glabra L. $\quad 97$

Malvaceae (Mallow Family) 97

Abelmoschus esculentus (L.) Moench. $\quad 97$

Abelmoschus manihot (L.) Medik. $\quad 97$

Abutilon indicum (L.) Sweet 98

Hibiscus rosa-sinensis L. $\quad 98$

Hibiscus tiliaceus L. $\quad 98$

Malvastrum coromandelianum (L.) Garcke $\quad 99$

Sida fallax Walp. $\quad 99$

Sida rhombifolia L. $\quad 99$

Thespesia populnea (L.) Sol. ex Correa $\quad 99$

Meliaceae (Mahogany Family) 100

Melia azedarach L. 100

Moraceae (Mulberry Family) 100

Artocarpus altilis (Park.) Fosb. 100

Artocarpus mariannensis Trec. 100

Ficus carica L. 101

Ficus tinctoria Forst. f. 101

Moringaceae (Moringa Family) 101

$\begin{array}{ll}\text { Moringa oleifera Lam. } & 101\end{array}$

Myrtaceae (Myrtle Family) 102

Eucalyptus sp. $\quad 102$

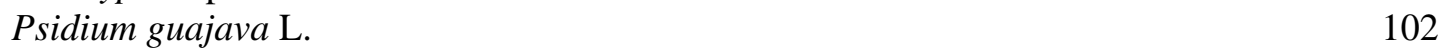

$\begin{array}{lr}\text { Syzygium malaccense (L.) Merr. and Perry } & 102\end{array}$

Nyctaginaceae (Four-O'Clock Family) 102

Boerhavia repens L. 102

Boerhavia tetrandra G. Forst. 103

Bougainvillea glabra Choisy 103

Bougainvillea x buttiana Holttum \& Standley 103

Mirabilis jalapa L. 103

Pisonia grandis R. Brown 104

Olacaceae (Olax Family) 104

Ximenia americana L. 104

Oleaceae (Olive Family) 104

Jasminum sambac (L.) Ait. 104

Onagraceae (Evening Primrose Family) 104

Ludwigia octovalvis (Jacq.) Raven 104

Oxalidaceae (Wood Sorrel Family) 105

Averrhoa carambola L. 105 
Oxalis corniculata L. $\quad 105$

Passifloraceae (Passion Flower Family) 105

Passiflora edulis Sims 105

Phytolacaceae (Pokeweed Family) 105

Rivina humilis L. 105

Piperaceae (Pepper Family) 106

Peperomia pellucida (L.) HBK. 106

Piper aduncum L. 106

Polemoniaceae (Phlox Family) 106

Phlox x drummondi Hook. 106

Polygonaceae (Buckwheat Family) 106

Coccoloba uvifera (L.) Jacq. 106

Portulacaceae (Purslane Family) 107

Portulaca australis Endl. 107

Portulaca grandiflora Hook. $\quad 107$

Portulaca lutea Solander ex Forst. f. 107

Portulaca oleracea L. $\quad 107$

Portulaca umbraticola Kunth subsp. umbraticola 108

Rhamnaceae (Buckthorn Family) 108

Colubrina asiatica (L.) Brongn. $\quad 108$

Zizyphus mauritiana Lam. 108

Rhizophoraceae (Mangrove Family) 108

Rhizophora stylosa Griff. 108

Rubiaceae (Coffee Family) 109

Dentella repens J. \& G. Forst. 109

Gardenia augusta (L.) Merr. $\quad 109$

Gardenia taitensis DC. $\quad 110$

Guettarda speciosa L. 110

Hedyotis romanzoffiensis (C \& S) Fosb. 110

Ixora casei Hance $\quad 111$

Ixora chinensis Lam. $\quad 111$

Morinda citrifolia L. $\quad 111$

Oldenlandia corymbosa L. $\quad 111$

Spermacoce assurgens Ruiz and Pav.

Timonius polygamus (Forst. f.) Robinson 112

Rutaceae (Rue Family) 112

Citrus aurantifolia (Christm.) Swingle 112

Citrus limon (L.) Burm. f.

Citrus mitis Blanco 112

Murray koenigii (L.) Spreng. $\quad 113$

Santalaceae (Sandalwood Family) 113

Santalum yasi Seem x S. album L. 113

Scrophulariaceae (Snapdragon Family) 113

Russelia equisetiformis Schlect. and Cham. 113

Simaroubaceae (Quassia Family) 114

Soulamea amara Lam. 114

Solanaceae (Nightshade Family) 114

Capsicum annuum L. vars. 114

Capsicum annuum L. var. grossum (L.) Sendtn. 114

Capsicum frutescens L. 114

Cestrum nocturnum L. 115 
Petunia hybrida Vilm. $\quad 115$

Physalis angulata L. 115

Solanum lycopersicum L.

Solanum melongena L. 115

Sterculiaceae (Cocoa Family) 116

Waltheria indica L. 116

Surianaceae (Suriana Family) 116

Suriana maritima L. 116

Tiliaceae (Linden Family) 116

Triumfetta procumbens Forst. f. $\quad 116$

Turneraceae (Turnera Family) 117

Turnera ulmifolia L. 117

Urticaceae (Nettle Family) 117

Laportea interrupta (L.) Chew 117

Laportea ruderalis (Forst. f.) Chew 117

Pilea microphylla (L.) Liebm. 117

Pipturus argenteus (Forst. f.) Wedd. var. argenteus 118

Procris pedunculata (Forst.) Wedd. 118

Verbenaceae (Verbena Family) 118

Clerodendrum inerme L. 118

Duranta erecta L. 119

Lantana camara L. 119

Premna serratifolia L. $\quad 119$

Stachytarpheta cayennensis (Ruioz \& Pavon) Vahl 120

$\begin{array}{lr}\text { Stachytarpheta jamaicensis (L.) Vahl } & 120\end{array}$

Vitex trifolia L. var. bicolor (Lam) Mold. $\quad 120$

Vitaceae (Grape Family) 120

Vitis sp. $\quad 120$

ACKNOWLEDGMENTS $\quad 121$

APPENDIX: CHECKLISTS OF INDIGENOUS AND ABORIGINAL PLANTS OF

TUVALU $\quad 122$

REFERENCES 127 


\title{
THE FLORA OF TUVALU: LAKAU MO MOUKU O TUVALU
}

\author{
R. R. THAMAN*
}

\begin{abstract}
This paper is a compilation and analysis of vascular plants that have been reported present on the eight atolls of the independent nation of Tuvalu in the Central Pacific. It is based on field inventories conducted by the author and collaborators between 1991 and 2016 plus available published and unpublished records of vascular plant collections and observations made since the late 1800s. The indigenous vegetation and flora of Tuvalu are highly disturbed and the flora is now numerically dominated by introduced exotic species. This has been the result of a long post-European contact and British colonial heritage, including over a century of planting monocultural coconut plantations; extensive habitat destruction, excavation and conversion of much of the best cultivable land from "borrow pits" to build airstrips during World War II; rapid population growth, including the migration from outer atolls to, and the expansion of, the main settlement and government center on Funafuti Atoll; and increased shipping and air services and agricultural development projects that have facilitated the introduction of new plants.

The total number of vascular plant species that have been recorded at some time on Tuvalu, including all indigenous and introduced species, is about 362 species or distinct varieties, of which only about 59 (16\%) are possibly indigenous. The remaining 303 species (83\% of the flora) are non-indigenous species that have been introduced by humans, some of which may have been at one time or another early aboriginal introductions. There are no endemic species that are unique to Tuvalu, with almost all of the indigenous plants being widespread, easily-dispersed coastal species that have the ability to cope successfully in the harsh atoll environment. The low number of indigenous species is an indication of the lack of habitat diversity on atolls compared with larger high islands, the difficulty of cross-ocean dispersal by plants, and the difficulty of long-term survival in the harsh atoll environment, which is dominated by poor soils, high salinity and physiological drought. Despite the degradation, the 362 or so plant species that still survive in Tuvalu are the only plants that the inhabitants have to satisfy many of their most important cultural, economic and environmental needs and to give them resilience against climate and global change.
\end{abstract}

\section{DEDICATION}

To the present and future generations of Tuvaluans, whose atolls and communities are clearly on the frontline in the global battle against climate, environmental and cultural change and whose first line of defense is the conservation and enrichment of their life-giving atoll plants.

* Emeritus Professor of Pacific Islands Biogeography, The University of the South Pacific (USP), Suva, Fiji Islands.Thaman_r@usp.ac.fj. 


\section{INTRODUCTION}

This publication is a compilation of information from previous studies and studies carried out by the author and additional contributors since his first visit to the island in 1991. It is hoped that the study will help preserve irreplaceable knowledge about the plants that have made and will to continue to make life liveable on Tuvalu and serve as a foundation for much of the culture on the nine atolls of Tuvalu. Particular emphasis is placed on the plants and vegetation of Funafuti Atoll, Tuvalu's capital, the most heavily populated atoll and the atoll with the most diverse flora and where most collections and observations have been made.

It is stressed that although atolls are biodiversity "cool spots” with among the most limited but highly threatened indigenous and introduced floras, and virtually no endemic species (Fosberg 1949; Thaman 2004a, 2008), it is this very limited and highly threatened flora that provide Tuvaluans and other atoll communities with cultural richness, food and productive security, and protection against climate, environmental and economic changes beyond their control. It is a rich but floristically poor inheritance that is highly threatened by increasing population, urban development, habitat change, land degradation, tsunamis, extreme weather and tidal events, and climate change. Other emerging negative impacts include alien invasive plants, animals and diseases, and the loss of traditional names and cultural knowledge about plants (Thaman et al. 2012).

It is stressed that Tuvalu and other Pacific atoll and small island nations and communities are clearly on the frontline against sea-level rise, climate change and extreme events such as tropical cyclones, droughts, king tides (the very highest spring tides, technically known as perigean spring tides, that occur a few times per year), storm waves and increasing salinity. Land shortage, invasive species and diseases, pollution and waste disposal and economic downturns are also serious concerns in atolls (Thaman 2008). As suggested above, perhaps the greatest insurance against these negative phenomena, most of which are beyond the control of atoll governments and communities, is the protection, enrichment and sustainable use of very limited plants resources.

Included in this study are (1) a brief description of previous and current studies of the vascular plants, vegetation and ethnobotany of Tuvalu; (2) introductory information on the geography, environment, people, culture, history, and economy of Tuvalu; (3) brief discussions of the flora and vegetation of Tuvalu, with particular emphasis on Funafuti, indigenous plants, and the ecological and cultural value of plants to Tuvalu; (4) a discussion of the Tuvaluan language and plant names; and (5) a selection of photos of some of the atolls and atoll islets to provide the reader with an idea of the types of environments and places where plants grow. These are followed by (1) an annotated systematic listing of vascular plants reported present in Tuvalu and (2) a bibliography of sources cited and useful references on the plants and vegetation of Tuvalu and the Pacific Islands that provided the basis for the study.

Plants included are all vascular or "higher plants"-plants that have true roots and a vascular system of tissue that conducts water, dissolved nutrients and products from photosynthesis throughout the plant. The main groups of vascular plants are (1) ferns and fern allies, (2) gymnosperms, and (3) flowering plants or angiosperms. They are listed in this order in the annotated systematic list. Non-vascular plants, such as mosses and lichens and a wide range of seaweeds (algae), of which there are a good number in Tuvalu, are not included.

Ferns and fern (Pteridophytes) allies are the most primitive vascular plants. They have no true flowers or seeds and are dispersed and reproduced by very small spores contained in small bundles on the underside of their fronds (leaves). In Tuvalu they are represented by plants such as laukatafa (Asplenium nidus), sulufe (Nephrolepis acutifolia) and maile (Microsorum grossum).

Gymnosperms (Gymnospermae) are ancient vascular plants that have true, but "naked,” seeds that do not form inside fruits and are normally formed in cone-like structures. They also do not have true flowers. They include cycads (laupama) and trees with cones, such as the tall Araucaria pines at the Vaiaku Lagi Hotel.

Angiosperms or flowering plants (Magnoliophyta) are the most diverse and advanced group of vascular plants. They include two sub-groups, Monocotyledons (monocots) and Dicotyledons (dicots), the latter being the most diverse and ancient of the two. The monocots typically have (1) only one seed leaf or 
cotyledon (the leaf that sprouts first from the seed before the real leaves grow), (2) parallel leaf veins, (3) vascular bundles scattered in their stems, rather than in concentric rings, and, (4) flower parts in threes or combinations of threes (e.g., three, six or nine). The dicots, on the other hand, have (1) two embryonic seed leaves (cotyledons), (2) mature leaves with branched, reticulate or netted veins, (3) vascular bundles in their stems forming concentric rings, and (4) flowers usually in multiples of four or five.

The monocots, which comprise about one-quarter of all flowering plants, include some of Tuvalu's and the world's most important plant families, such as the palms, bananas, pandanus, taros, grasses and lilies. The dicots, which comprise about three-quarters of all flowering plants, are by far the most diverse and include most of the larger trees and shrubs and a high percentage of the smaller soft or herbaceous plants in Tuvalu.

\section{PREVIOUS AND CURRENT STUDIES}

The main published works on the flora, vegetation and ethnobotany of Tuvalu are Hedley's (1896) “General Account of the Atoll Funafuti Atoll”; Maiden’s (1904) “The Botany of Funafuti, Ellice Group”; Woodroffe's "Vegetation of Vaitupu, Tuvalu” (1981), "Vegetation and Flora of Nui Atoll, Tuvalu” (1985), and "Vegetation of Tuvalu" (1991); Koch's The Material Culture of Tuvalu (1983), based on studies of Niutao, Nanumaga and Nukufetau in 1960-1961, and his later study "Plants for Humans - On Reef Islands in the Pacific: Niutao + Nonouti” (2002); and Chamber's (1984) "Nanumea” from Atoll Economy: Social Change in Kiribati and Tuvalu. These works focus mainly on indigenous or traditionally important cultural plants with little focus on more recently introduced food and ornamental plants. More recent works are Thaman and Whistler's "Strategies for the Protection and Planting of Trees" (1995) and A Review of Uses and Status of Trees and Forests in Land-Use Systems in Samoa, Tonga, Kiribati and Tuvalu with Recommendations for Future Action (1996); Seluka's Traditional, Current and Potential Uses of Forests, Trees \& Other Plants of Tuvalu (1997); and Thaman, Fihaki and Fong's (2013) book Plants of Tuvalu: Lākau no mouku o Tuvalu. The latter is a guide including photos that focuses on the most common or culturally important plants of Tuvalu rather than on the entire recorded flora.

The current study of the flora and vegetation of Funafuti commenced 25 years ago in September 1991 when the author visited Funafuti on a South Pacific Regional Environment Programme (SPREP)-funded trip to prepare Tuvalu: National Report for the United Nations Conference on Environment and Development (UNCED), Rio de Janeiro, Brazil, June 1992 (Thaman and Neemia 1991). Subsequent week-long visits included Thaman and Whistler's visit in September 1993 to conduct a study of the status of trees in land-use systems in Tuvalu; Thaman, Fong and Fihaki's week-long study in May 2010, during which the plant lists from 1991, 1993 and 2003 were updated, added to and verified with the local Tuvaluan coauthor and contributors to that study; and a five-day visit to Funafuti in March 2016, after which the lists were again updated, added to and verified.

During the 1991 and 1993 visits, voucher specimens were collected for new or unidentified plants and conventional photos taken of most plants and the vegetation. The voucher specimens were lodged in the South Pacific Regional Herbarium at the University of the South Pacific (USP) in Suva, Fiji. During the 2003, 2010 and 2016 visits, almost all species were photo-documented with digital photos that were subsequently numbered and annotated. The numbers have been entered, along with the numbers for the earlier voucher specimens, into the annotated species listing that follows. Species of uncertain identity were later identified, in most cases by W. A. Whistler, based on the digital photos. In 2010, an attempt was made to systematically record the local Tuvaluan names and uses for all plants for all the atolls, with particular focus on Funafuti and Nanumea as representative of the southern and northern dialects of Tuvaluan. All of these studies have contributed to this flora. 


\section{GEOGRAPHY AND ENVIRONMENT}

The atoll nation of Tuvalu (known as the Ellice Islands when it was part of the British Gilbert and Ellice Islands colony) became a fully independent nation-state in 1978 and full member of the United Nations in 2000. The nine small low-lying limestone islands or atolls ${ }^{1}$ have a total land area of only 25.9 $\mathrm{km}^{2}$ spread over an ocean area of about 1.3 million $\mathrm{km}^{2}$ between $5^{\circ} \mathrm{S}$ and $10.5^{\circ} \mathrm{S}$ latitude and $176^{\circ} \mathrm{E}$ and $179.5^{\circ} \mathrm{E}$ longitude (Carter 1984; Douglas and Douglas 1989; Goldberg 2016). The nearest neighboring island groups are Kiribati (Gilbert Islands/Tenggaru), Samoa, Fiji, Wallis and Futuna, and the isolated island of Rotuma, which is part of Fiji (Figure 1).

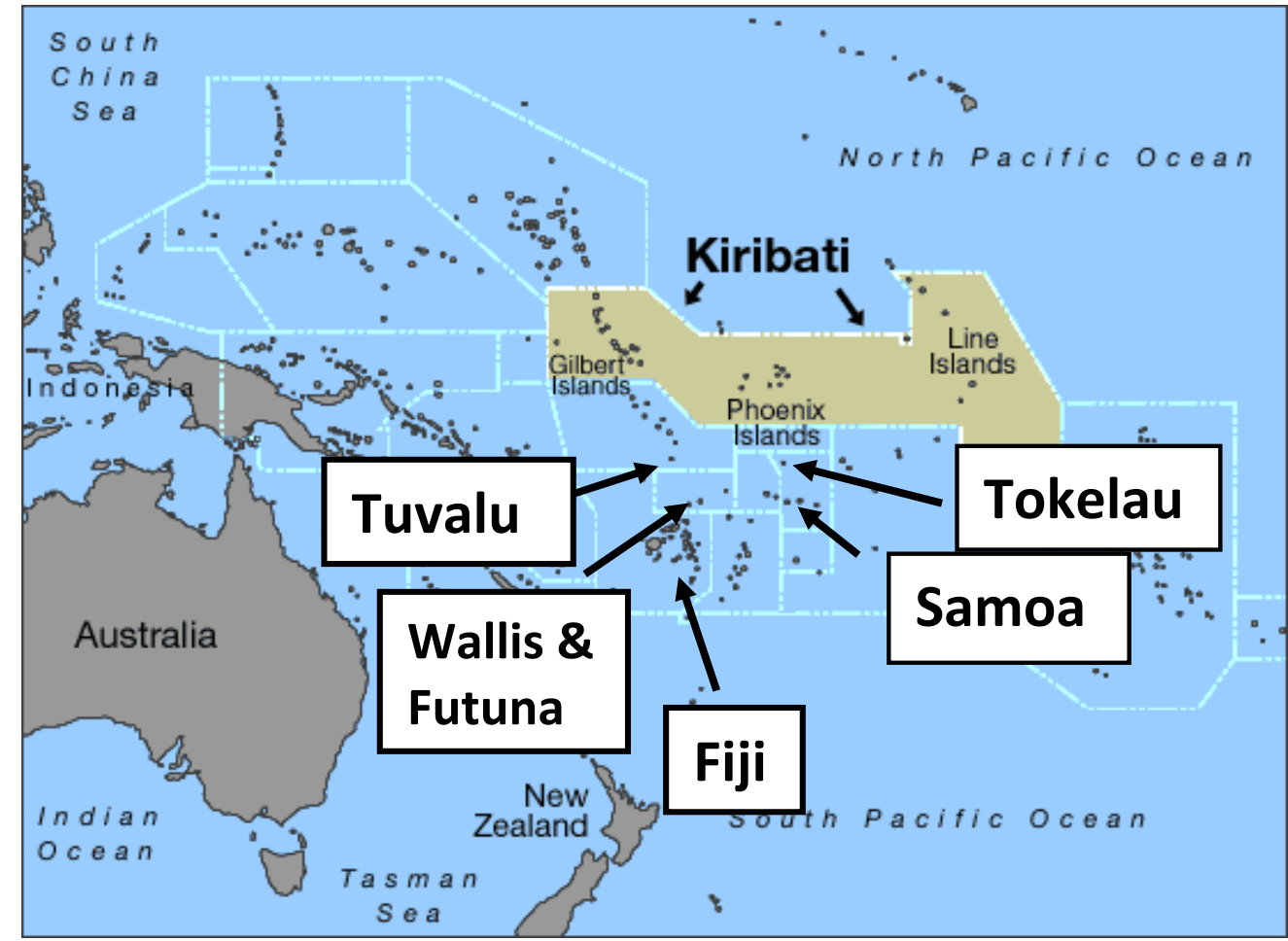

Figure 1. Map showing the location of Tuvalu in relation to the nearby island groups of Kiribati, Wallis and Futuna, Fiji, Samoa and Tokelau. (Source: Adapted from http://www.climate.gov.ki/about-kiribati/)

The nine islands, which extend over a distance of about $570 \mathrm{~km}$ from Nanumea in the northwest to Niulakita in the southeast (Figure 2), include five classic "true atolls" consisting of varying numbers of reef islets or motu surrounding or bordering a central lagoon or lagoons (Nanumea, Nui, Nukufetau, Funafuti and Nukulaelae; Figure 3); three small raised limestone islands with no central lagoon, but with

\footnotetext{
1 The common dictionary definitions of an atoll vary from a ring-like coral island enclosing a lagoon to a circular coral reef or string of coral islands surrounding a lagoon. As stressed by Wiens $(1962)$, Bryan $(1953,1972)$ and others, these definitions are far too simplistic because most groups of atolls, such as Tuvalu, consist not only of "true atolls" with lagoons, but also of other small, single, sometimes lagoon-less, low-lying limestone islands (Thaman 2008). Goldberg's (2016) revision of Bryan's (1953) checklist of the atolls of the world excludes low-lying raised limestone islands without lagoons from the true atolls. Coral islands may be formed of calcareous sand, coral, or coral-reef limestone deposits (Wiens 1962). Islets (motu in Polynesian and Tuvaluan) are smaller islands that encircle, border (on reefs) or are found within a lagoon of the main atoll island. The Tuvalu group therefore encompasses true atolls, islets (motu), and individual, separate low-lying limestone reef islands that have no lagoon or may have "secondary" or remnant "fossil" lagoons on the actual limestone island or islets (Thaman 2008).
} 
small remnant landlocked "fossil” lagoons (Niutao, Nanumaga and Niulakita); and the largest island in the group, Vaitupu, a pear-shaped limestone island with an area of $5.6 \mathrm{~km}^{2}$ and two small relatively landlocked internal lagoons (Figure 3). Most of the islands of Tuvalu have an average elevation of about $2 \mathrm{~m}$ with only limited areas rising above $3 \mathrm{~m}$ (Carter 1984; Rogers 1991; Thaman et al. 2013). Goldberg (2016) includes eight of these islands as true atolls based on the presence of a central lagoon with connection to the ocean, excluding Niulakita because its lagoon is now infilled (Goldberg 2016, table A.17). From a floristic and ecological standpoint Niulakita is included because its similar island elevation, rather than the presence of a lagoon, is the most important ecological determinant for flora.

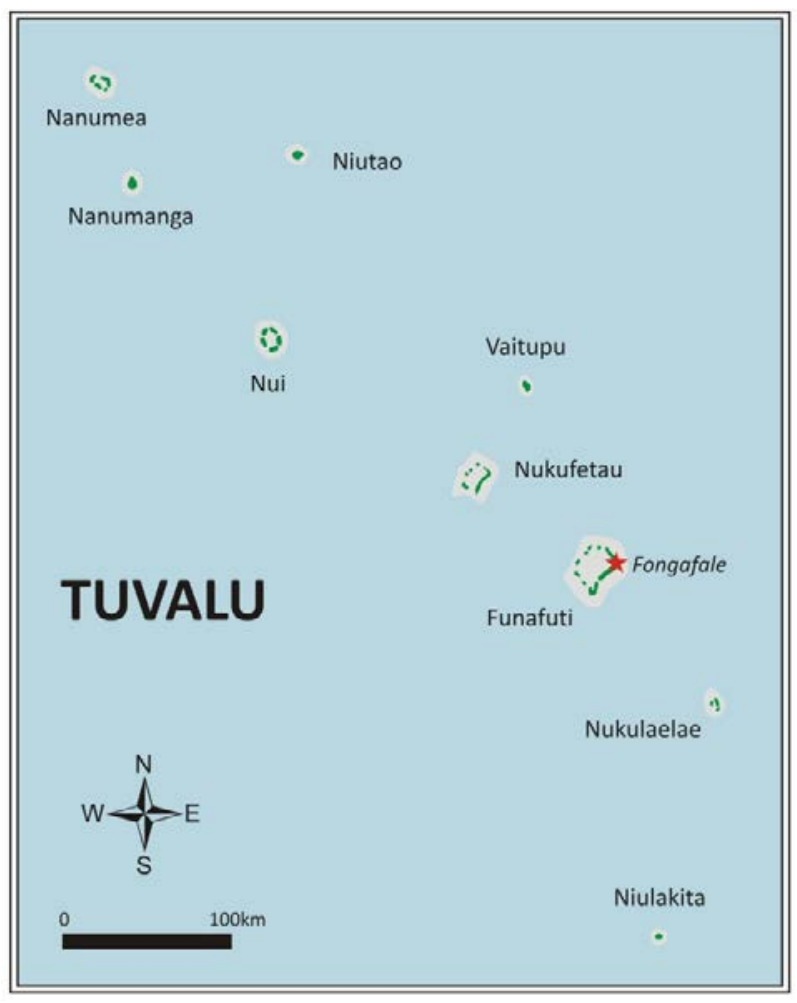

Figure 2. Map of Tuvalu showing the locations of the nine atolls from Nanumea in the northwest to Niulakita in the southeast (Source: www.nowshoptime.com)
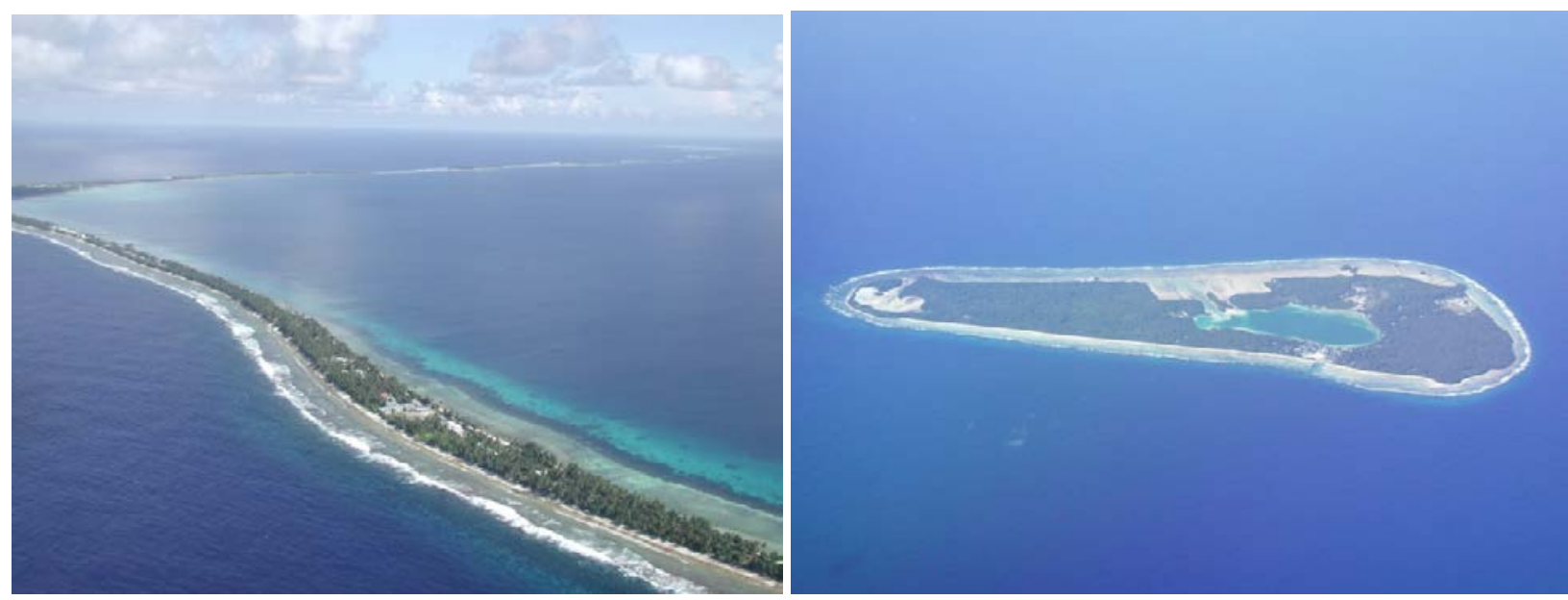

Figure 3. Aerial photos of Fogafale Islet, Funafuti Atoll (left) showing the open ocean on the left and the central lagoon on the right; and Vaitupu Atoll (right) with two small almost landlocked lagoons (far left and center right). (Photos: R. Thaman 2003) 
Funafuti, the most highly populated atoll and capital of Tuvalu has 33 islets encircling a lagoon about $23 \mathrm{~km}$ long and $18 \mathrm{~km}$ wide with a surface area of about $275 \mathrm{~km}^{2}$, by far the largest lagoon in Tuvalu (Figure 4). The total land area of Funafuti is $2.8 \mathrm{~km}^{2}$ and Fogafale, the largest and easternmost individual islet, which is about $500 \mathrm{~m}$ across at its widest point, has a land area of about $1.45 \mathrm{~km}^{2}$. Fogafale has four main villages, Fakai Fou, Senala, Alapi, and Vaiaku, the seat of the Tuvalu government, although the entire atoll of Funafuti is officially the capital. One-third of the total area of Fogafale has historically been unavailable to development until late 2015 due to the presence of the airstrip and the highly-degraded "borrow pits" from which soil, sand and aggregate were excavated to build the airstrip during World War II (Carter 1984; Douglas and Douglas 1989; Smith 1995). In 2015-2016 the borrow pits were reclaimed by infilling with marine sediments dredged from Funafuti's central lagoon. The currently most prominent structures and developments on the atoll include the Taiwan government-funded Tuvalu Government Building completed in 2004, the Vaiaku Lagi Hotel, the air terminal and runway, the new Tuvalu Sports Complex, which was developed with imported soil (and weeds) from Fiji, the Church of Tuvalu in Vaiaku, and the port and Princess Margaret Hospital to the north of the main settlement. There are also new settlements in South and North Fogafale that accommodate communities from the other atolls.

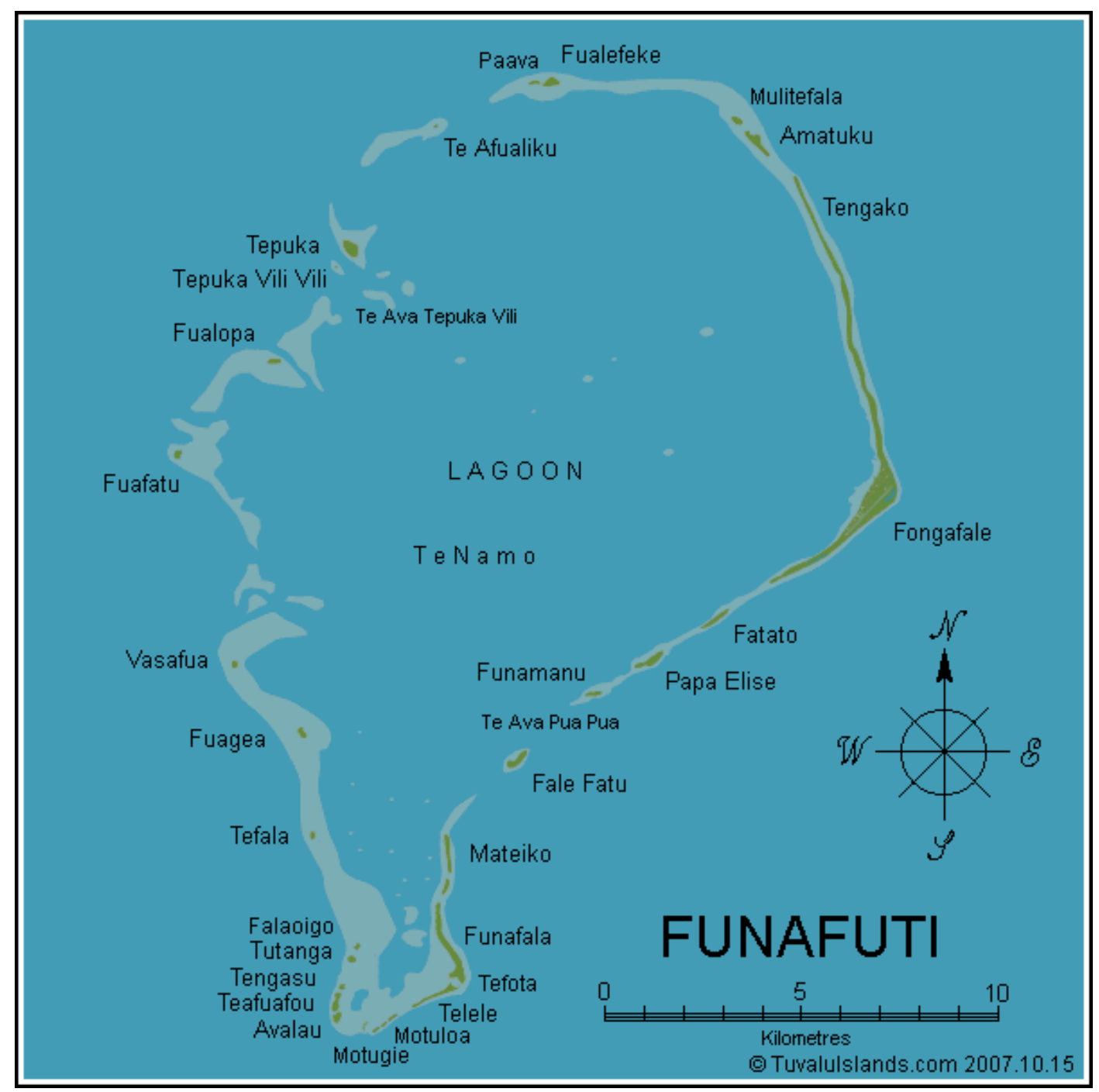

Figure 4. Map of Funafuti Atoll showing the central lagoon and the individual reef islets (motu), including Fogafale Islet, the largest and most populated islet and capitol of Tuvalu, along the eastern side of the lagoon. (Source: TuvaluIslands.com) 
The estimated population of Tuvalu in March 2016 was 10,157, down from an estimated 10,782 in 2014 due to emigration overseas. Population densities are about 425 per $\mathrm{km}^{2}$ for Tuvalu and probably over 2000 per $\mathrm{km}^{2}$ for Funafuti, where about half of the population lives, almost all of whom are on Fogafale Islet (Index Mundi 2014; Country Meters 2016). The people are predominantly Polynesians, although the people of Nui Atoll are culturally and linguistically Micronesians of I Kiribati descent and, because of the long relationship with Kiribati under the Gilbert and Ellice Islands Colony, there has been considerable intermarriage between Tuvaluans and I Kiribati and a strong Kiribati influence on Tuvaluan culture, including the use of plants.

From the ocean to the lagoon side of a typical atoll islet there is normally distinctive zonation of substrates and associated vegetation (Fosberg 1949). In the case of Funafuti, there is usually a fringing limestone reef in the wave zone on the ocean side, which may be covered by sand or beach rock (Figure 5). The beach then becomes a raised rampart or ridge of coral rubble deposited during storms. This is commonly the highest portion of the islet, normally no more than $4 \mathrm{~m}$ above mean sea level. This is the case along the east coast of Funafuti, where there is a substantial coral rubble or shingle rampart that has been thrown up by major tropical cyclones (Figure 6), the most recent of which was Tropical Cyclone Bebe in 1971 (Fitchett 1987). Inland from the rampart and extending toward the lagoon are areas of windblown sand and a thin layer of soil. In the case of Fogafale Islet, Funafuti, just inland from the rampart is a limited area with a "back-beach" basin bordered with mangroves (Figure 7). Based on a geological map made in 1896 (McLean 2014), this area formerly covered much of the interior part of Fogafale Islet before the airstrip was built in 1942 (Kayanne 2009). Toward the lagoon shore, increasingly fine deposits are of lagoonal origin. Limestone outcrops or pavements with little or no soil and low-lying swampy areas or areas that are periodically inundated are also common (Fosberg 1949; Thaman 2008).

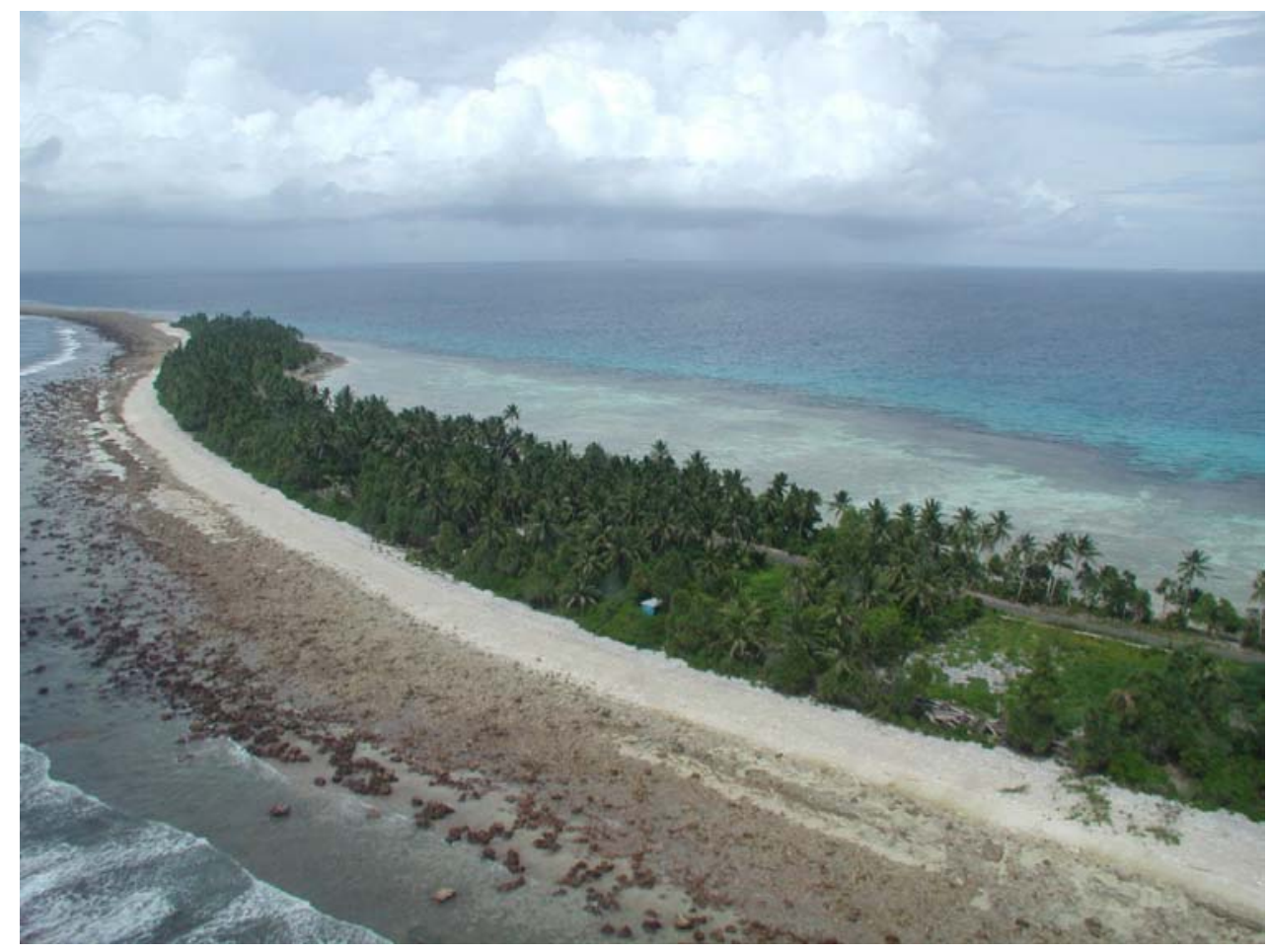

Figure 5. Aerial views looking west across south Fogafale Islet, Funafuti Atoll, showing the ocean side fringing reef encrusted with red coralline algae, the intertidal reef flat, beach and upraised coral rampart, inhabited and vegetated zone and the central lagoon. (Photo: R. Thaman 2003) 


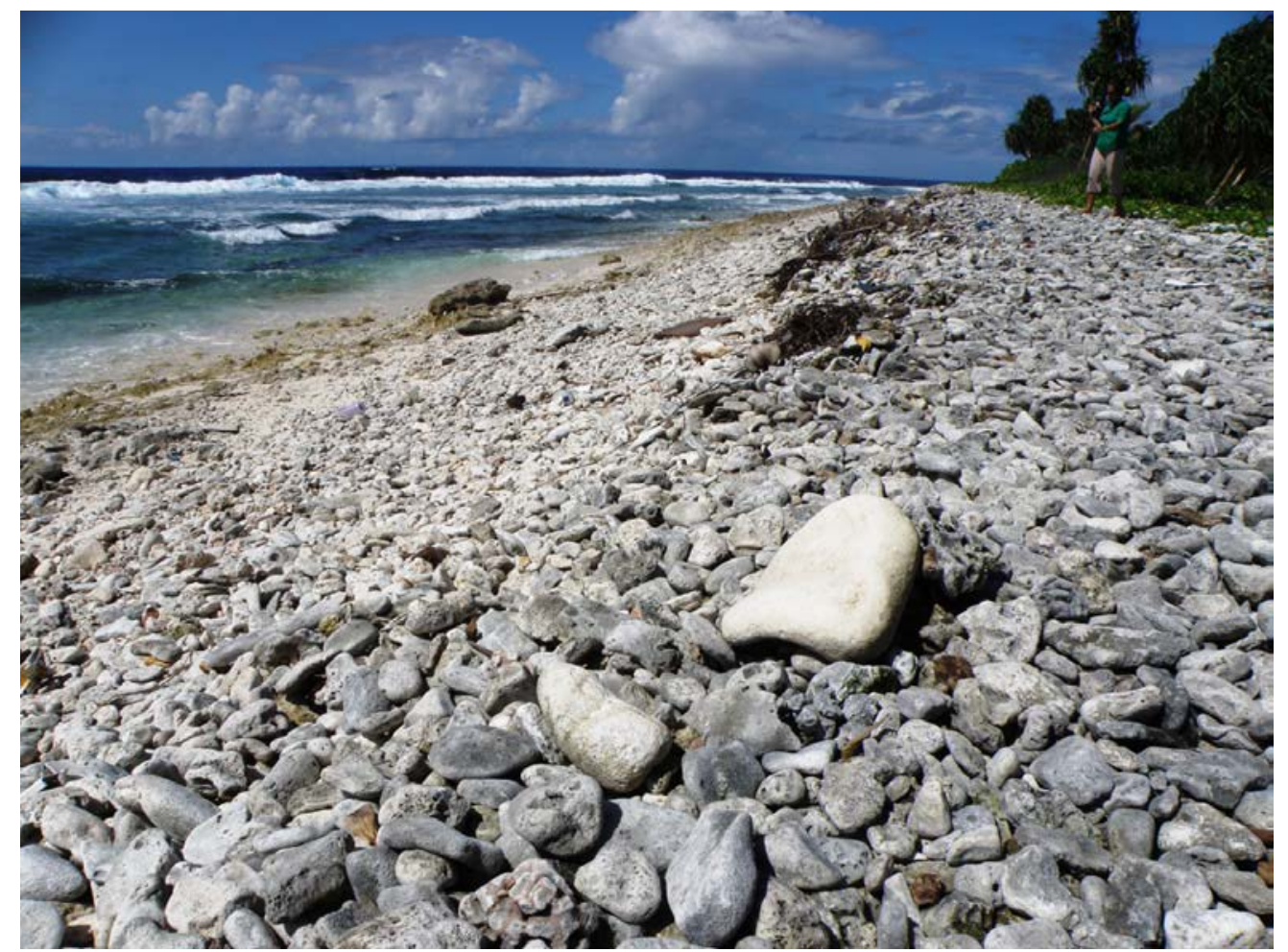

Figure 6. Coral rubble rampart transported onshore by tropical cyclone waves and storm surge, the most recent serous event being Tropical Cyclone Bebe in 1971. (Photo: R. Thaman 2010)

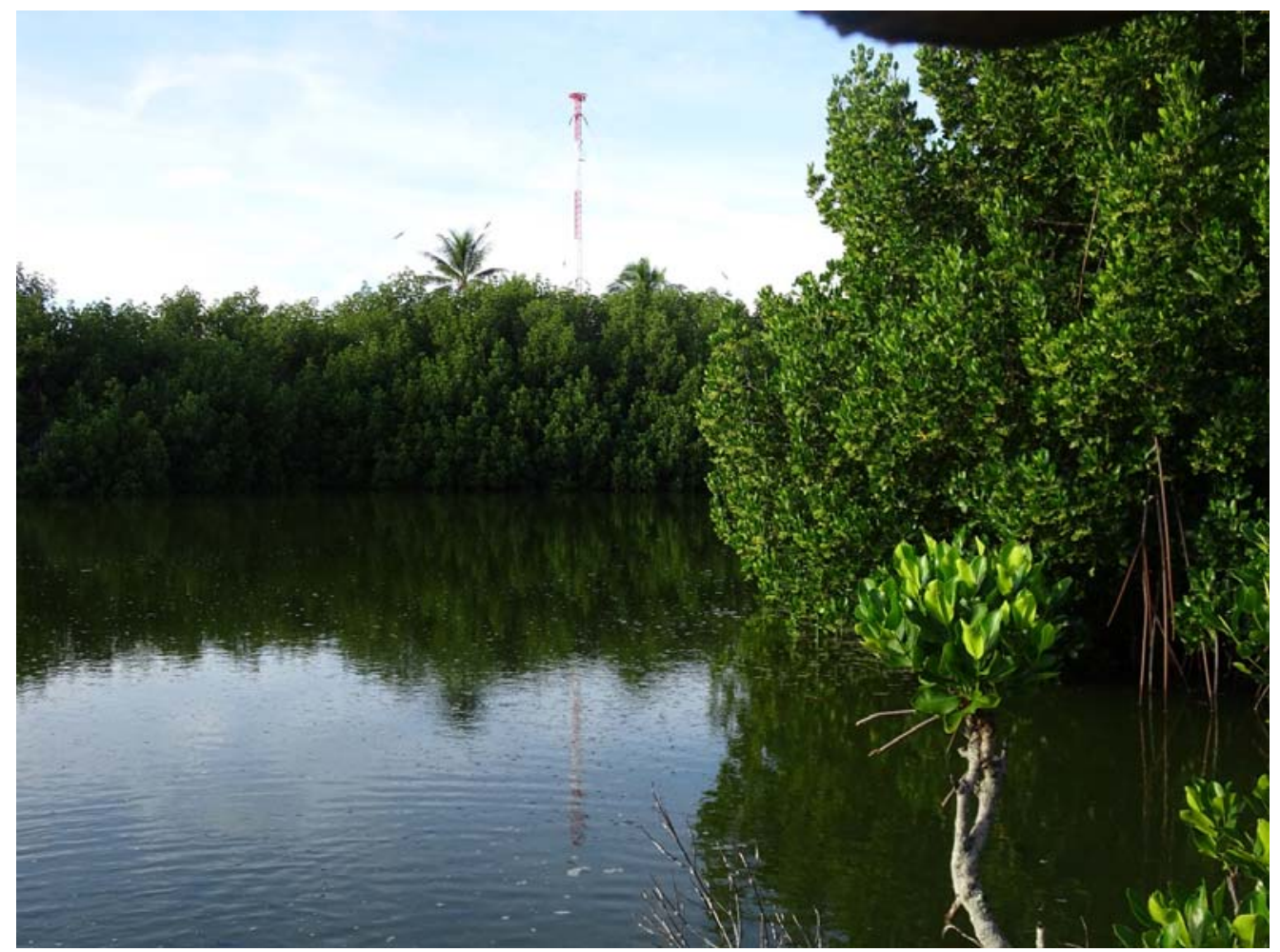

Figure 7. Back-beach basin bordered by mangroves, togo (Rhizophora stylosa), east Fogafale Islet, Funafuti. (Photo: R. Thaman 2016) 
There are no significant surface freshwater resources on the atolls. The only permanent freshwater resource is groundwater in the form of a lens of often slightly brackish freshwater hydrostatically floating on higher-density saltwater beneath it. The height of the freshwater lens above sea level and the level of salinity vary in relation to the elevation, geology, texture, shape and width of islets, the amount of salt water incursion resulting from tidal surge and the amount of water use and rainfall. Replenishment or recharge of the lens is dependent on rainfall. During high rainfall periods, especially those coinciding with king tides, pools are sometimes found in areas where the lens is close to the surface. The location and degree of development of the groundwater resource influences the nature of the vegetation, as well as the location of village wells and excavated taro pits. On Funafuti the freshwater lens is most extensive and most highly developed on the largest islet, Fogafale, where it provides the most favorable conditions on the atoll for both native and introduced plants and for the excavation of traditional taro pits (pela) to the level of the freshwater lens (SOPAC 2007).

Climatically, Tuvalu is located in the southeast tradewinds belt of the South Pacific Ocean and has a tropical maritime climate. The annual temperature range is between a daily average maximum of $31^{\circ} \mathrm{C}$ and a daily average minimum of $25^{\circ} \mathrm{C}$. Two seasons are recognized: a cooler season, between March and October, when the southeast tradewinds are strongest, and a warmer rainier season from November to February, when the winds are more westerly or northerly. Annual rainfall ranges from about $2000 \mathrm{~mm}$ in the drier northern islands of Nanumaga and Niutao to $3500 \mathrm{~mm}$ in the wetter southern atolls, such as Funafuti, with most rain coming during the warm season (Rodgers 1991). Tropical cyclones were historically uncommon, with major tropical cyclones affecting Tuvalu in 1891, 1972 (Tropical Cyclone Bebe), and 1990 (Tropical Cyclones Val and Ofa). Most recently, during Tropical Cyclone Pam in March 2015, strong winds and storm surge that coincided with a high spring ("king") tide inundated the atolls of Nui and Nukufetau, causing serious damage to agriculture and forcing more than 300 people to evacuate their homes (Malaki and North 2015). In December 2015 gale force winds and rain during Tropical Cyclone Ula destroyed homes and uprooted trees (Pacific Beat 2015).

High waves and storm surge coupled with normal spring or higher king tides affect both the ocean and lagoon coasts and often flood the interior areas of atolls. These events cause (1) coastal erosion and the loss of coastal plants and vegetation and (2) inundation of areas with saltwater, saltwater contamination (incursion) of the freshwater lens, and increased salt spray, all of which can kill or affect the growth and reproduction of non-coastal plants on atolls, and can worsen the impact of periodic droughts.

El Niño-related severe droughts periodically affect Tuvalu, especially the northern atolls (Thaman et al. 2013) and constitute a major limiting factor on the long-term survival of plants, particularly introduced non-coastal plants. The drought of 2011 was particularly serious, during which a state of emergency was declared in September 2011 due to water shortage on Funafuti (Vula 2011). During the most recent study in March 2016, Tuvalu was again experiencing drought conditions due to the 2015-2016 El Niño event.

The substrates and soils (surfaces on which plants can grow) of Tuvalu are among the poorest in the world. They include exposed limestone rock, beach rock or reef rock, sand and gravel, loamy sands, acid peat soils, swamp or hydromorphic organic soils or muds created in excavated taro pits, and artificial soils. The natural soils are normally shallow, porous, alkaline, coarse-textured, and have carbonatic mineralogy and high $\mathrm{pH}$ values of up to 8.2 to 8.9. They are usually deficient in most of the important nutrients needed for plant growth (e.g., nitrogen, potassium and micronutrients such as iron, manganese, copper and zinc; Morrison 1987; SOPAC 2007).

In late 2015, the reclamation and infilling of extensive areas of borrow pits with dredged lagoon sediments was completed on both north and south Fogafale Islet. The dredged material consists of mainly biogenic sand consisting of shallow-water benthic foraminifera along with varying proportions of calcareous algae, coral, mollusk and other marine invertebrate remains. The dredging continued in early 2016 to reclaim a large area extending some $100 \mathrm{~m}$ on the lagoon side of the Tuvalu Government Building and the Vaiaku Lagi Hotel using dredged sediments with a higher proportion of calcareous algae, mainly Halimeda spp. that make up a large proportion of sediments of Funafuti Lagoon (Figure 8; Smith 1995). 


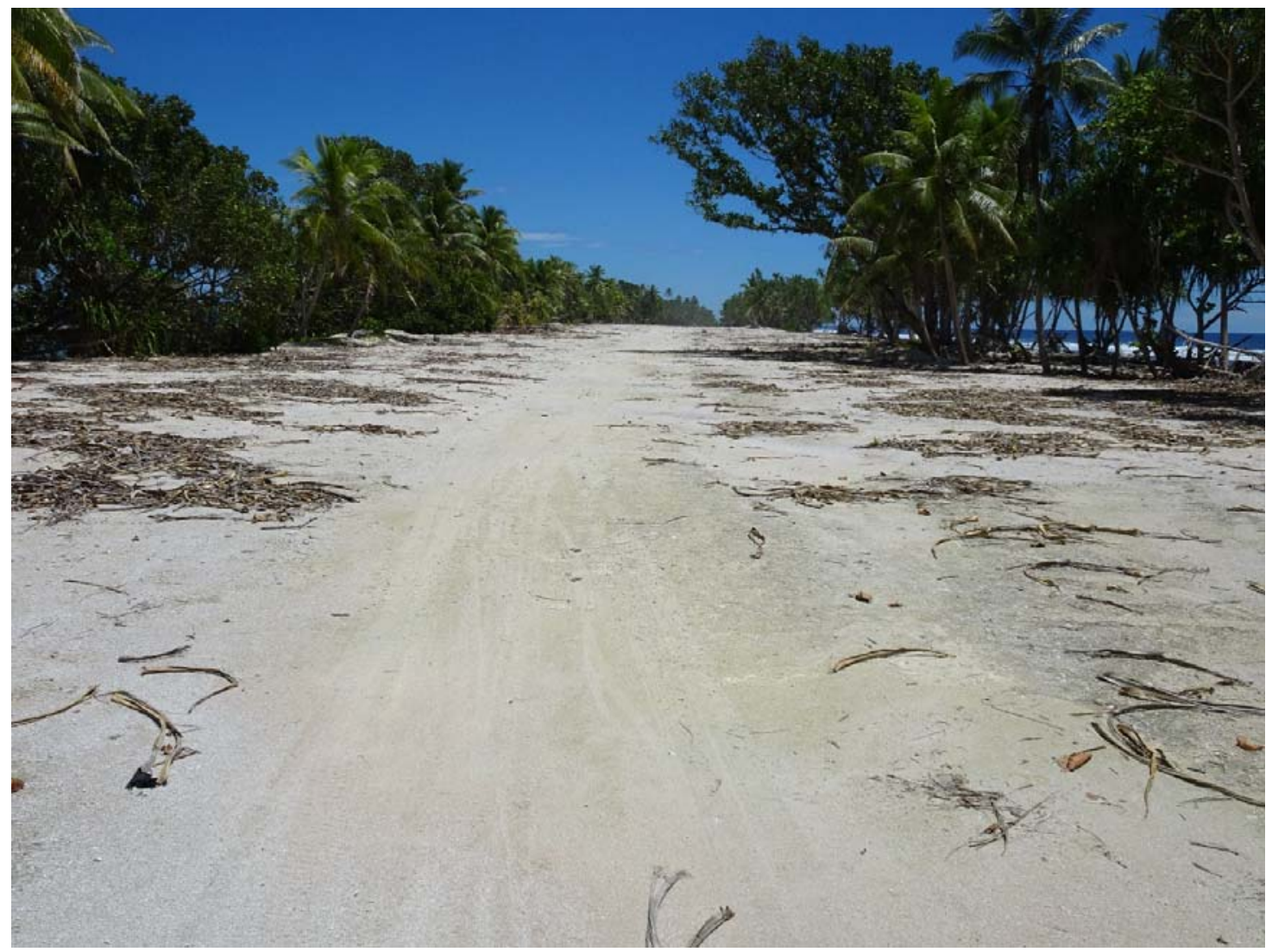

Figure 8. Former borrow pits north of the garbage dump reclaimed in 2015 and infilled with lagoon sediment dredged from Funafuti Lagoon. (Photo: R. Thaman 2016)

\section{PEOPLE, HISTORY AND ECONOMY}

Tuvalu has been settled for over 2000 years by Polynesians, who, based on linguistic affinity and oral history, were most likely from Samoa. Nui Atoll was settled by people from Kiribati. There was later contact with Tongans beginning in the mid-thirteenth century and beyond when Tuvalu fell within the sphere of influence of Tonga. This is reflected most on Nanumea and Nanumaga, where the language is closer to Tongan (Laracy 1983; Carter 1984; Bellwood 1987).

According to Carter (1984), the first recorded European contact with Tuvalu was in 1568, when Mendaña sighted Nui. The next recorded visits were not until over 150 years later, in the early 1800s. These included the visits to Funafuti and Nukufetau in 1819 by Captain Arent de Peyster, when he named the group the Ellice Islands, as well as stops at three atolls by Charles Wilkes of the U.S. Exploring Expedition in 1841. From the 1820s until about 1870 the waters of Tuvalu were visited by whalers, some of whom stayed, took local wives and/or became traders. In the 1860s, Christianity arrived, and pastors (mainly Samoan) living on a number of the atolls converted many to Christianity using the Samoan Bible and had a very strong and continuing influence on the culture. In 1863, with promises that they would be taught about Christianity, some 400 people from Funafuti and Nukulaelae were taken by "blackbirders" (slavers) to work in guano mines in Peru. None returned. Others were later recruited to work on plantations in Fiji, Samoa and Hawai'i, where some still reside (Carter 1984; Douglas and Douglas 1989).

In 1877, Tuvalu came under the British sphere of influence and was brought under the jurisdiction of the High Commissioner for the Western Pacific in Fiji. From 1892 to 1916, the Ellice Islands were administered by the UK as part of a protectorate and from 1916 to 1974 as part of the Gilbert and Ellice Islands Colony. During World War II, although no actual fighting took place in Tuvalu, several thousand troops were based there to support war efforts in Kiribati and the Marshall Islands. Americans established 
a base and built an airstrip on Funafuti in 1942 and others on Nanumea and Nukufetau. After the war, an increasing number of Tuvaluans moved to Tarawa (in Kiribati), the capital of GEIC, for schooling or employment, many marrying I Kiribati (Kiribati nationals). During this period a large number of Tuvaluans and I Kiribati also worked as contract laborers in the phosphate industries of Nauru and Banaba (Ocean Island). After a referendum in 1974, Tuvalu was legally separated from Kiribati and became formally known as Tuvalu (rather than the Ellice Islands). On October 1, 1978, it became an independent country and in 2000 it became a full member of the United Nations. During the period leading up to and since independence, regular air links have been established, linking Tuvalu, Fiji, Tarawa and, at times, Nauru and the Marshall Islands (Carter 1984).

During all periods of Tuvaluan history, including the first settlement by Tuvaluans and pre-European contact with other Pacific Islands, but possibly excluding the first European discovery and the blackbirding episode, new plants have been introduced and adopted by Tuvaluans.

Economically, most Tuvaluans practice subsistence fishing, farming and the harvest of a range of wild, mainly plant, products. Only about one-quarter of the population participates in the formal wage economy. This is especially true outside Funafuti, where people depend on fish and other sea foods, coconut, breadfruit, bananas, taro, a limited number of other crops, pigs, chickens, seabirds and some wild plants, such as the bird's nest fern (laukatafa), as their main locally produced foods. The limited number of indigenous wild plants and other plants are also the main sources of traditional medicines, fuel, construction and boatbuilding materials, handicrafts, garlands, perfumes and a wide range of other products (Thaman et al. 2013)

Until independence, the main source of cash income and foreign exchange was coconut oil and copra made from the dried flesh of coconuts. The sale of Tuvalu's stamps has historically also been a significant source of government revenue. Wage employment is almost exclusively with the government in the public sector, with a limited number of people working in a small private sector. The main sources of government revenue and foreign exchange are currently licensing fees and royalties from foreign vessels fishing within Tuvalu's 200-mile Exclusive Economic Zone (EEZ), remittances from Tuvaluan merchant seamen, fishermen and others working or living overseas, official development aid and income from the Tuvalu Trust Fund that was established at the time of independence. Substantial income has also come from the lease of Tuvalu's Internet domain name, “.tv.” There is only limited tourism, with most visitors being consultants, officials of international and regional organizations and business people (Laracy 1983; Carter 1984; Thaman et al. 2013).

\section{VEGETATION AND FLORA}

The indigenous vegetation and flora of Tuvalu are highly disturbed and the flora is now numerically dominated by introduced exotic species. This has been the result of the following periods of development:

1. Long settlement of the atolls for over two thousand years by indigenous Tuvaluans and other

Pacific Islanders who brought with them a range of culturally useful plants and possibly some associated weeds.

2. A long post-European contact and British colonial heritage, including over a century of planting monocultural coconut plantations for the export production of coconut oil and copra on most available productive land, including most uninhabited atoll islets or motu. During this period there was also significant movement of Tuvaluans as contract workers to work in the phosphate mines of Nauru and Banaba or elsewhere or as emigrants to resettle on Kioa Island and other areas in Fiji or elsewhere overseas from which new plants were introduced into the country.

3. Extensive habitat destruction and conversion of much of the best cultivable land on Funafuti and large areas on Nanumea and Nukulaelae, including the excavation of materials from "borrow pits” to build airstrips during World War II.

4. Since independence in 1979, rapid population growth, including the migration from outer atolls to, and the expansion of, the main settlement and government center on Fogafale Islet, Funafuti. During this period and continuing to this day there has been an increase in shipping and air 
services and agricultural development projects that have increased the frequency and ability of people to introduce new plants.

5. Finally, as reported above, the degraded and excavated former "borrow pits" and the extensive area along the lagoon in central Fogafale, which have recently been reclaimed and infilled with lagoon sediments, will probably be less fertile than existing soils and will require considerable rehabilitation and enrichment if vegetation is to be re-established.

Throughout all of these periods of development, there has been selective removal of indigenous species and vegetation for growth of settlements, construction, boatbuilding, firewood, medicine, tools, handicrafts and other purposes, and the deliberate and accidental introduction of a wide range of nonindigenous plants, some of which have become important cultural plants and some which are now invasive weeds (Thaman et al. 2013)

The resultant total number of terrestrial vascular plants reported present at some time in Tuvalu is about 362 species or distinct varieties, of which only about 59 (16\%) are possibly indigenous (Table 1; also see Table A.1). The remaining 303 species (84\% of the flora) are non-indigenous species that have been introduced by humans, some of which (about 12 or more) may have been at one time or another early aboriginal introductions by Pacific Islanders into some of the atolls of Tuvalu. The total recorded flora of Funafuti is about 356, with 7 additional indigenous species having been reported from the other atolls (Woodroffe 1981, 1985, 1991).

There are no endemic species that are unique to Tuvalu since all of the indigenous plants are widespread, easily dispersed pantropical or pan-Pacific coastal species that have the ability to cope successfully in environments with loose shifting sands, soilless limestone and rock outcrops, high wave action, high salinity and sea spray, periodic flooding, strong sunlight, strong winds and drought, all conditions that are common on the atolls of Tuvalu. The low number of indigenous species is an indication of the lack of habitat diversity on atolls compared with larger high islands, the low probability of cross-ocean dispersal by plants, and the difficulty of long-term establishment and survival in the harsh atoll environment that is dominated by high salinity (Fosberg 1946; Thaman 2008; Thaman et al. 2013; Goldberg 2016).

Of the 59 possibly indigenous species, 6 are widespread pantropical or paleotropical ferns or fern allies, and 53 are angiosperms or flowering plants, of which 19 are monocotyledons and 48 are dicotyledons (Table A.1). There are no indigenous gymnosperms.

Of the 303 non-indigenous or exotic species, 14 could be aboriginal introductions that were brought to Tuvalu before European-contact times by either Tuvaluans or other Pacific Islanders, such as I Kiribati, Tokelauans, Samoans or Tongans who have historical links with Tuvalu (Table A.2). Because it is hard to determine what the original flora was, some of the species considered to be indigenous could have, in fact, also been early deliberate or accidental aboriginal introductions or even early post-European contact introductions. The remaining 290 species have probably been introduced since the time of first European contact by Mendaña in the latter half of the 1500s, most of which have probably been introduced since the introduction of Christianity in the 1860s, during the establishment of American bases in Tuvalu 1942 during World War II, and, most recently after Tuvaluan independence in 1978 and the establishment of

Table 1. Number of vascular plants reported present in Tuvalu by assumed origin. Note that some species may no longer be present and are now locally extinct, there are undoubtedly some species that have not been recorded, and some species have probably been incorrectly classified because of the difficulty of determining their true origin.

\begin{tabular}{lrrrr}
\hline Plant Class & Indigenous & Aboriginal & Recent & Total \\
\hline Ferns and Fern Allies & 6 & - & 3 & 9 \\
Gymnosperms & - & - & 2 & 2 \\
Monocotyledons & 11 & 8 & 84 & 103 \\
Dicotyledons & 42 & 6 & 200 & 248 \\
Total & 59 & 14 & 289 & 362 \\
\hline
\end{tabular}


regular air and shipping links with Fiji and other Pacific Island sources of introduced plant materials. Most of these recently introduced species are weeds, ornamental plants and food plants. A relatively high number of these have either remained in very low numbers or are no longer present.

As stressed by Fosberg in his paper "Atoll Vegetation and Salinity” (1949):

Though numerous species have been tried out, both by the plant-loving natives and by residents of foreign origin, relatively few of them have survived. Still fewer can be considered successful even under the protection and cultivation of man. Those that survive, but are not especially successful, show, without exception, signs of a severe localized chlorosis (yellow coloring) of the type usually associated with excessive sodium, with resultant deficiency of assimilated potassium and a more general chlorosis possibly associated with deficiencies of other ions due, perhaps, to high $\mathrm{pH}$. Lantana camara, ordinarily a most aggressive weed, is yellow and sterile where planted in the Marshall Islands. Even some of the species, such as the papaya, which survive and reproduce themselves, are often chlorotic. Also these species are much more successful toward the center of an islet where the salinity is naturally lower. Very few of the introduced plants, excepting those which are themselves strand plants with a tolerance toward high salinity, or those which are shallow-rooted, thus living in the upper layers where the salt is to some extent leached out by rains, have succeeded in becoming naturalized.

Fosberg's statement clearly reflects the situation in Tuvalu.

\section{Vegetation}

As stressed in the introduction, despite severe habitat degradation, selective removal and harvesting of high-value trees and plants and increasing numbers of introduced species, there remains a significant amount of indigenous vegetation in various stages of disturbance, particularly in small stands of inland and coastal forest or mangroves and more extensive areas of scrub or shrub land where indigenous species remain dominant. On uninhabited reef islets and areas away from the main settlements, indigenous species are still largely the dominant species, although impoverished by selective removal of some species and the planting of coconut palms.

From the most "natural" to the most highly modified or disturbed vegetation, the main vegetation types include:

- inland broadleaf forest and woodland

- coastal littoral forest and scrub

- mangroves and wetlands

- coconut woodland and agroforest

- excavated taro gardens

- village houseyard and urban gardens

- intensive vegetable and food gardens

- disturbed ruderal vegetation

- recently reclaimed unvegetated areas infilled with lagoon sediment

The main vegetation types, of which there are many combinations and shared species, have been discussed in detail by Woodroofe in his "Vegetation of Tuvalu” (1991). They are discussed briefly below with the descriptions of dominant species discussed in more detail in the section on the flora and in the annotated systematic listing.

\section{Inland Broadleaf Forest and Woodland}

Relatively undisturbed areas of inland broadleaf atoll forest and woodland in the central portions of atolls islets are rare on Funafuti, limited in area or represented by scattered remnant trees and now mainly found in small stands or as scattered trees on uninhabited reef islets (motu). 
Dominant species in remaining inner coastal forest and woodland include puka vai (Pisonia grandis) and puka vaka (Hernandia nymphaeifolia), both of which form small stands on some atolls. Other common to uncommon species include fala (Pandanus tectorius), pua (Guettarda speciosa), kanava (Cordia subcordata), tausunu (Tournefortia argentea), fao (Ochrosia oppositifolia), fetau (Calophyllum inophyllum), milo (Thespesia populnea) and futu (Barringtonia asiatica). Smaller trees or shrubs include fou tangata (Pipturus argenteusi), ogoogo (Acalypha grandis), valovalo (Premna serratifolia), nonu (Morinda citrifolia) and gasu (Scevola taccada). Important understory species include the ferns laukatafa (Asplenium nidus), sulufe (Nephrolepis acutifolia) and maile (Microsorum grossum); the sedge mouku milimili taliga (Fimbristylis cymosa); and the grasses Lepturus repens, Stenotaphrum micranthum and Thuarea involuta, all known generally as mouku (Woodroofe 1991; Thaman et al. 2013).

\section{Coastal Littoral Forest and Scrub}

The least disturbed areas of coastal littoral forest and scrub (those plants that grow along the outer coastline) are found mainly on uninhabited islets along both exposed ocean and more protected lagoon coasts and on coastlines bordering passes between the ocean and lagoon. Dominant species include the shrubs gasu (Scaevola taccada) and gie (Pemphis acidula), the latter of which is found most commonly in coastal scrub on limestone pavements along the lagoon shore. Also present along some coasts is Surana maritima, also known as gie. The dominant tree is tausunu (Tournefortia argentea), which is often seen as a wind- and salt-effected, stunted shrub. Other important trees include kanava (Cordia subcordata), pua (Guettarda speciosa) and talie (Terminalia samoensis). Common understory, creeping or climbing herbaceous or slightly woody species found extending out onto beaches include the fern maile (Microsorum grossum), the sedge mouku milimili taliga (Fimbristylis cymosa), and the grasses Lepturus repens and Thuarea involute. Common vines include fue (Ipomoea pes-caprae), fue or fue kena (Ipomoea macrantha), legumes Vigna marina and Canavalia cathartica, both known as saketa, and fetai (Cassytha filiformis), a leafless parasitic creeping vine that commonly festoons coastal vegetation. Herbaceous or slightly woody smaller plants include tolotolo (Triumfetta procumbens), mouku toto (Chamaesyce chamissonis), kisikisi (Boerhavia tetrandra), tamatama or sisi vao (Achyranthes canescens), luna (Laportea ruderalis) and katuli (Portulaca australis) (Woodroffe 1991; Thaman et al. 2013).

\section{Mangroves and Wetlands}

Although limited in extent, mangroves and limited areas of swampy wetlands are found on all of Tuvalu's atolls except Nukulaelae, along protected intertidal lagoon flats or in back-beach basins. The only two true mangrove species present in Tuvalu are the common mangrove, togo (Rhizophora stylosa), which is found on all atolls except Nukulaelae, and the red-flowered mangrove, sagale or hagale (Lumnitzera littorea), which is currently reported present only on Nanumaga, Niutao, Nui, and Vaitupu. On Funafuti, togo (Rhizophora stylosa) is locally abundant and forms dense thickets to the northeast of the airfield where it surrounds the lagoon or the back-beach intertidal basin landward of the ocean-coast coral rubble and shingle rampart along the east coast of Fogafale Islet (see Figure 7 above). An 1896 geological map (McLean 2014 and references therein) of Fogafale Islet shows that this back-beach swamp area covered a much more extensive area of the east-central part of the islet in the past before the construction of the airstrip in 1942 and the expansion of the government settlement (Kayanne 2009). Sagale or hagale, although now only found on Niutao, Nui, Vaitupu and Nanumaga, was reportedly present on Funafuti and Nukulaelae in the past where it was known as tokotū but has long since disappeared due to land conversion and overuse of its very useful wood. The principle associated species seem to be gie (Pemphis acidula), milo (Thespesia populnea) and the grass Paspalum vaginatum (Woodroffe 1991).

\section{Coconut Woodland and Agroforest}

The most widespread vegetation type in Tuvalu is coconut-dominated agroforest or woodland, which is described in detail as coconut woodland by Woodroffe (1991). The term agroforest is here used to describe those agricultural lands dominated by deliberately planted or protected useful trees, in this case almost 
exclusively the coconut palm, niu (Cocos nucifera), although other useful indigenous trees are often protected and allowed to remain, and pandanus, breadfruit and other useful trees are occasionally planted, sometimes as small tree groves in more favorable sites, usually near villages or residences. Associated species, depending on the degree of maintenance of the former coconut plantations and the degree of regeneration of vegetation in unmaintained or abandoned plantations, include most of those species found in the inland and coastal littoral associations discussed above. The most common woody species are pua (Guettarda speciosa), gasu (Scaevola taccada) along with ogoogo (Acalypha grandis), fou tagata (Pipturus argenteus) and nonu (Morinda citrifolia). Important understory species, especially in more open sites, include the ferns laukatafa (Asplenium nidus), sulufe (Nephrolepis acutifolia) and maile (Microsorum grossum), the sedge mouku milimili taliga (Fimbristylis cymosa), and the grasses Lepturus repens, Stenotaphrum micranthum and Thuarea involute. Also present in these areas, dependent on the level of disturbance, are a range of introduced weed species that are discussed in more detail below.

\section{Excavated Taro Pits}

Excavated taro pits (pela) are unique, specialized and highly modified communal garden areas found in the central parts of the larger atoll islets, normally near the main settlements. The pits have been excavated to the level of the freshwater lens through the limestone bedrock, to depths of $1.5-2 \mathrm{~m}$. The artificial soils in these pits are fertile, swampy and rich in organic material and have been formed over many years by adding mulch or compost, known as kaiao, which is composed of leaves and other organic materials. On Funafuti, the only remaining extensive taro pit is located in Vaiaku, just north of the airport to the west of the runway. The main crop planted in the pela is giant swamp taro, pulaka (Cyrtosperma chamissonis), although common taro, talo (Colocasia esculenta), is also common on Funafuti, often planted in slightly raised beds bordering the pulaka (Figure 9). Bananas and plantains (Musa cultivars) are planted in contiguous stands bordering the pits. (The name Funafuti means the place of the futi, the general word for bananas and plantains.) Other food plants such sugarcane, tolo (Saccharum officiarum), are also seen planted along the margins of these gardens. Occasional weeds include the sedge mouku filifou (Mariscus javanicus), the grass Paspalum vaginatum, and other herbaceous or subshrubby species, mouku solo (Commelina diffusa), lakau pula sega (Ludwigia octovalvis) and lita (Rorippa sarmentosum).

\section{Village Houseyard and Urban Gardens}

Due to increasing population and urbanization, houseyard and urban gardens are one of the most widespread vegetation types, especially on Fogafale Islet and in villages and government centers on the other atolls. These include houseyard gardens around family dwellings and workplaces; landscaping at hotels, schools, and government and non-government developments; and lawns, hedges and living fencing and street trees and other roadside plantings. Houseyard and urban gardens are a mixture of a wide range of deliberately planted indigenous and non-indigenous trees, shrubs, vines and other perennials and some short-term annual plants, plus many non-planted wild or weedy species. Over the past ten years or so home gardening, including the planting of ornamentals at homes, has been promoted via competitions. The actual species planted in such areas are discussed in detail under introduced plants. 


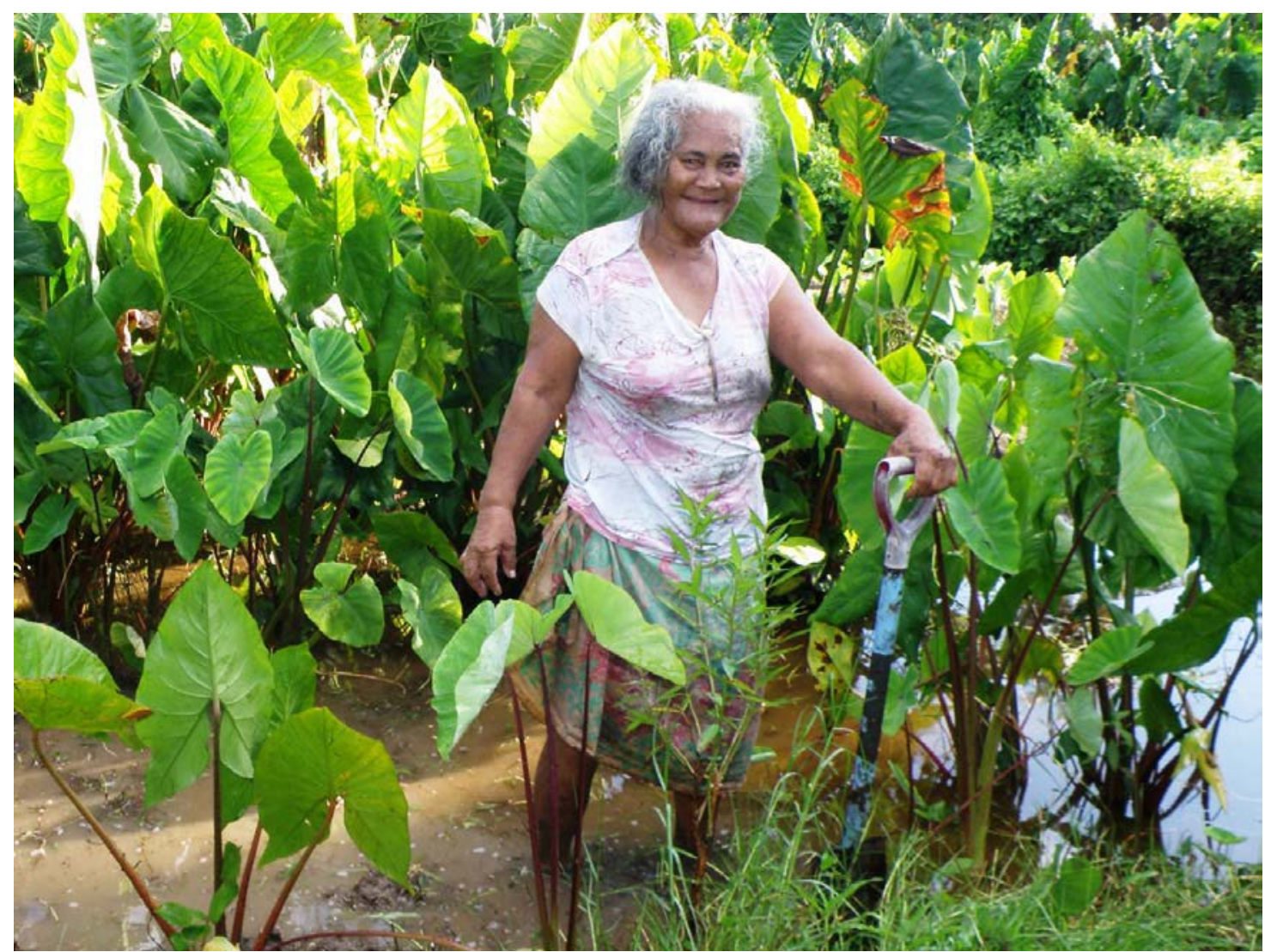

Figure 9. Excavated taro pits on Fogafale Islet with the taller giant swamp taro, pulaka (Cyrtosperma chamissonis), behind and true taro, talo (Colocasia esculenta), in front of the woman. (Photo: R. Thaman 2010)

\section{Intensive Vegetable and Food Gardens}

Intensive vegetable and food gardens, originally growing mainly non-traditional short-term seed crops and some other recently introduced perennial shrub and tree food plants, are increasingly important on Funafuti and on some other atolls, such as Vaitupu. This has been in response to a number of initiatives over the past 20 years or more to improve nutrition and increase production and consumption of vitamin-rich vegetables and fruits in an effort to reduce the dependence on nutritionally inferior, highly processed imported foods and drinks that are the main causal factor in the rapid increase in obesity, diabetes, cardiovascular and dental disease and a range of other "lifestyle diseases" in Tuvalu. These initiatives include a series of houseyard food garden initiatives, such as the UNICEF Home Garden Development Programme; the Technical Mission of Taiwan's International Cooperation and Development Fund's (ICDF) vegetable production project, which has recently expanded from Funafuti to Vaitupu; and the Pacific Regional Agricultural Project (PRAP) Atoll Farming Systems Programme in the late 1990s and early 2000s. The soils of these gardens have been enriched by adding organic materials, such as pulverized coconut husk or decaying logs, animal manure, sand or soil from more fertile sites and imported fertilizers and manures.

Most recently there are a number of initiatives promoting agriculture systems that support food security and build resilience against climate change. These include the Tuvalu Department of Agriculture Nursery for Utilising Climate Resilient Crops and a number of demonstration agroforestry plots in North and South Fogafale Islet that incorporate mainly traditional tree crops, such as coconut palms, pandanus, breadfruit, bananas and native figs (Ficus tinctoria) along with staple root crops such as cassava, sweet potato, taros or aroids (Colocasia, Cyrtosperma and Xanthosoma spp.) and yams, plus a number of other introduced plants. The main funders have been the European Union and its Global Climate Change 
Alliance (GCCA), along with the Secretariat of the Pacific Community (SPC), the Food and Agricultural Organization (FAO) of the United Nations, and the Australian Centre for Agricultural Research (ACIR).

\section{Disturbed Ruderal Vegetation}

Increasing urbanization and the development of roads, airports and other facilities have created extensive areas of continually disturbed ruderal vegetation, especially on Fogafale Islet. These include roadsides, path sides, waste places, open lots, sports grounds, limited areas of lawns and grassy areas, unpaved areas around parking lots, airports and landing strips and other areas that are continually disturbed and/or not maintained or weeded. The dominant plants in these areas are a wide range of easily-dispersed, fast-growing herbaceous weedy species (grasses, sedges and other herbs, mostly referred to as mouku, the general term for small weeds) and some weedy shrubs. Some of these weeds, such as Sphagneticola trilobata, have become extremely invasive and constitute a threat to ecologically and cultural important indigenous species throughout much of the atoll and small island Pacific (Thaman 1999, 2011). The range of species found in ruderal sites is discussed in detail below.

\section{Flora}

As discussed above, the total number of terrestrial vascular plants reported present at some time in Tuvalu, is about 362 species or distinct varieties, of which only 59 (16\%) are possibly indigenous (see Table 1). The remaining 303 species (84\% of the flora) are non-indigenous exotic species that have been introduced by humans. Below is a short discussion of the indigenous species that include the most widespread and most useful plants in Tuvalu, and a brief mention of some plants that could have been aboriginal introductions by indigenous Pacific Islanders before European contact. Most of these species plus the more important recently introduced plants, including some of the more common or potentially invasive weeds, are discussed below in the annotated systematic list of the flora.

\section{Indigenous Species}

As stressed above, of the 59 possibly indigenous species, 6 are widespread pantropical or paleotropical ferns or fern allies and 53 are angiosperms or flowering plants, of which 11 are monocotyledons and 42 are dicotyledons.

The six indigenous ferns and fern allies, all of which have been reported present on Funafuti, include psilotum or reed fern, Psilotum nudum (sai); the bird's-nest fern, Asplenium nidus (laukatafa); two sword ferns or fishtail ferns, Nephrolepis acutifolia and Nephrolepis hirsutula (both sulufe, hulufe); scented fern, Microsorum grossum (maile); and lacy fern or sword brake, Pteris tripartita (lautolo). Of these, Microsorum grossum, Nephrolepis acutifolia and Asplenium nidus are still common, especially on uninhabited reef islets, and Nephrolepis hirsutula and Pteris tripartita are occasional on Fogafale Islet.

There are only two gymnosperm species in Tuvalu, neither of which is indigenous. These are the cycad, laupama (Cycas rumphii), and Cook (named after Captain James Cook), columnar or New Caledonia pine (Araucaria columnaris), although the name pine is a misnomer as it is not a true pine in the genus Pinus.

The eleven possibly indigenous monocotyledons found on Funafuti include the coconut palm, niu (Cocos nucifera), and pandanus or screw pine, fala (Pandanus tectorius), the two most culturally useful trees in Tuvalu, both of which are abundant. Although considered indigenous, there are both wild and cultivated varieties of both species, some of the latter of which are certainly either aboriginal or recent introductions. Wild pandanus, which dominates the more exposed coral rubble ramparts of ocean-side coast of Funafuti, are known as fala vao ("bush" or "wild"), whereas the planted varieties, which have edible fruit or leaves, are known as fala kai ("edible”), fala tinakaleve, or falaketi; those cultivars used for making fine mats and other handicrafts are known as kie or by other names.

The nine remaining possibly indigenous monocotyledons (eight which are reported from Funafuti) consist of six grasses (Poaceae) and three sedges (Cyperaceae). The most common grasses include four widespread coastal grasses, Thuarea involuta (mouku solo), beach bunch grass Lepturus repens, Paspalum vaginatum and Stenotaphrum micranthum, a grass that is normally found inland in more 
protected sites. Rare or uncommon is Lepturopetium kuniense, which was collected in 1993 but not seen again since, and Ischaemum murinum, which was reported present with no location by Seluka (1997). The latter species are all referred to as mouku or sometimes mutia, general names for grasses or small weeds.

Possibly indigenous sedges include the common beach sedge Fimbristylis cymosa (mouku milimili taliga), marsh cyperus Mariscus javanicus (mouku filifou or mouku fai tika) and spike sedge Eleocharis dulcis, which has only been reported from Vaitupu and Nukulaelae. Although all widespread pantropical or subtropical species, some of these sedges could be aboriginal or more recent introductions.

Of the 48 dicotyledons considered to be possibly indigenous to Tuvalu, 43 have been reported present on Funafuti over the past century or more, although some have not been seen over the past three decades. The 48 species include 16 large or medium-sized trees, 16 small trees or shrubs, 6 vines or creepers, and 10 small herbaceous species.

Reasonably common large trees include puka vai (Pisonia grandis), one of the most common trees in relatively undisturbed inland broadleaf forest and woodland, especially on uninhabited islets, but widely removed from the main inhabited islet of Fogafale on Funafuti; puka vaka (Hernandia nymphaeifolia), an important component of some inland and coastal littoral forest along sheltered lagoon and occasional around villages; and fetau (Calophyllum inophyllum), a rare component in some inland areas, occasional in lagoon-side littoral forest, and occasionally planted in villages. Less common trees include futu (Barringtonia asiatica), which is uncommon in some protected coastal areas, inland areas and in villages, and milo (Thespesia populnea), formerly more common along protected coasts, areas bordering mangroves, such as in Vaitupu (Woodroofe 1991), and in villages, but now rare on Funafuti.

Smaller trees include tausunu (Tournefortia argentea), a common component of coastal littoral forest and some inland areas, often as a wind- and salt-effected, stunted shrub; kanava (Cordia subcordata) and pua (Guettarda speciosa), both occasional in protected coastal forests, woodlands and in villages; fao (Ochrosia oppositifolia), which is occasional in inland forest and woodland on Fogafale Islet on Funafuti and some larger islets on other atolls; valovalo (Premna serratifolia), a common small tree in woodlands, poorly maintained coconut plantations, and in village gardens; talie (Terminalia samoensis), which is occasional in sheltered coastal forests, woodlands and in some houseyard gardens; and fou fafine or fau (Hibiscus tiliaceus), which is found mainly in areas bordering the mangroves and in villages on Funafuti, but was apparently more common in the past, although some authorities believe that it might have been an aboriginal introduction (Whistler 2009).

Also important indigenous trees are the common mangrove, togo (Rhizophora stylosa), which is locally common to the northeast of the airport on Funafuti and is found on all the other atolls except Nukulaelae. The less common red-flowered black mangrove, sagale (Lumnitzera littorea), is now found only on Nanumaga, Niutao, Nui and Vaitupu, but, as stressed above, was reportedly also present in the past in the swampy areas that were cleared and infilled to build airstrips during World War II on Nukulaelae and also on Funafuti, where it was known as tokutū.

Indigenous shrubs or small trees include the ubiquitous saltbush or half-flower, gasu (Scaevola taccada), which is abundant in coastal littoral vegetation, especially on exposed ocean coasts and in scrub; pemphis, gie (Pemphis acidula), which is found in coastal scrub on limestone pavements, periodically inundated areas and bordering mangroves; ogoogo (Acalypha grandis) and fou tagata (Pipturus argenteus), both common in the understory of broadleaf and coconut woodland, in scrub and around excavated taro gardens; Indian mulberry or noni, nonu (Morinda citrifolia), a common understory species in inner coastal forest, scrub and coconut woodland and in village gardens; and native fig, felo (Ficus tinctoria), an occasional understory component in woodlands, scrub, houseyard gardens and around taro pits. Also reported present on Nui and Vaitupu, but only occasionally in houseyard gardens on Funafuti, is the beach privet, inato (Clerodendrum inerme), a common coastal plant and mangrove associate in Kiribati and throughout the Pacific.

Rare, possibly extirpated indigenous shrubs include beach sunflower, ateate (Wollastonia biflora), and akatā (Abutilon indicum), both reported present on Funafuti near the beginning of last century, but not recorded since. Other rare shrubs, not reported present in Tuvalu by Woodroffe (1991) but seen in limited populations in 2010, include silverbush (Sophora tomentosa), native soapbush, lakau sopu (Colubrina asiatica), akatā (Sida fallax), and Timonius polygamous. With the exception of Sida fallax, 
which may have been deliberately planted on Tepuka Islet, the others were seen growing naturally in coastal vegetation.

A shrub reported present by Woodroffe (1991) on Nanumea and Nui, but never from Funafuti, is talatalaamoa (Ximenia americana), a thorny shrub. Interestingly, talatalaamoa is the name also given to Caesalpinia bonduc, a thorny climbing vine that is often also found on atolls, and which one would expect to have been present at least sometime in the past in Tuvalu.

Of the six vines that have been reported from Funafuti, the most common are the beach morningglory, fue (Ipomoea pes-caprae), a spreading, creeping vine found in coastal littoral vegetation and in open inland and ruderal sites and around taro pits; moonflower or night-blooming morning-glory, fue or fue kena (Ipomoea macrantha), a climbing vine that is occasional in lagoon coastal forest, in inland forest, woodland and scrub, and occasionally in houseyard gardens; two legumes, both saketa, the beach pea (Vigna marina), a climbing and spreading vine with yellow flowers that is common in coastal strand and inland vegetation, and in ruderal sites, and Canavalia cathartica, a common climber with pink flowers in inner coastal vegetation along lagoons and in inland forests and woodlands; and beach dodder, fetai (Cassytha filiformis), a leafless parasitic vine that is commonly found climbing on coastal littoral vegetation, in scrublands and in ruderal sites. A rare, probably periodic arrival is the high-climbing sea bean, Mucuna gigantea, which was seen and photographed in 2003 on south Fogafale Islet, Funafuti, but has not been seen since.

Of the smaller indigenous herbaceous plants or slightly woody smaller plants (sub-shrubs), the most common species are the beach burr, tolotolo (Triumfetta procumbens), a succulent prostrate herb with trailing stems that is found on sandy and rocky coastal littoral vegetation, in open areas in woodlands and in ruderal sites, mainly on uninhabited reef islets; beach spurge, mouku toto (Chamaesyce chamissonis), which is locally common in coastal littoral vegetation and in open disturbed areas in woodland and coconut plantations on uninhabited reef islets; and kisikisi (Boerhavia tetrandra), a locally common spreading herb in eroded coastal sites and open areas in broadleaf woodland and scrub. Less common, rare or extirpated on Funafuti are the slightly woody herbs or sub-shrubs, both tamatama or sisi vao, Achyranthes canescens, which is reported from Nanumea and was seen in both 2003 and 2010 in the coastal vegetation of both Tepuka and Fualopa Islets, and Achyranthes aspera, a more weedy species that was reported present on a number of the other atolls and on Funafuti in the early 1900s but has not been seen since (possibly mistaken for A. canescens); luna (Laportea ruderalis), which is reported present on both Nanumaga and Vaitupu, from Funafuti in the early 1900s, and seen present on Tepuka Islet of Funafuti in openings in Pisonia woodland in 2003 and 2010; small-leaf portulaca, katuli (Portulaca australis), which has been reported from four other atolls and is seen in a couple of disturbed coastal sites on Fogafale Islet, just northeast of the airport and on the sandy beach ridge on the western side of the newly reclaimed area just north of the rubbish dump in the far north of Fogafale Islet. Herbaceous plants or sub-shrubs reported from other atolls in Tuvalu, but not from Funafuti, include Portulaca lutea (katuli) and Hedyotis romanzoffiensis, both reported from Nanumea and Nui; luna (Laportea interrupta), reported from Nui; and pigweed, mouku solo (Boerhavia repens), a somewhat weedy species that is normally found in disturbed sites, which was reported from Nukulaelae (Woodroffe 1991).

\section{Non-Indigenous Species}

Of the 303 non-indigenous or exotic species, 14 of which are possibly aboriginal introductions, 3 are ferns, 2 are gymnosperms, and 298 are flowering plants (angiosperms), 92 of which are monocotyledons and 206 dicotyledons. These are composed of almost entirely food and multipurpose plants, ornamentals and weedy species (Table 2). A relatively high number of these have either remained in very low numbers or are no longer present due to the harsh environmental conditions of the atolls. The discussion below will briefly discuss those plants that could have been aboriginal introductions. These remaining important species will be discussed in the systematic listing under each species.

Of the non-indigenous species, monocotyledons that could have been ancient pre-European contact aboriginal introductions include giant swamp taro, pulaka (Cyrtosperma chamissonis), true taro, talo (Colocasia esculenta), both important staple root crops, and possibly giant taro, tāmu or kape (Alocasia macrorrhizos); two banana cultivars, pata and kefu (both Musa ABB Group); and Polynesian arrowroot, 
vatia or niu 'a Naleau (Tacca leontopetaloides). Other monocotyledons that could have been introduced at one time or another before European contact are cordyline, ti (Cordyline fruticosa), and sugar cane, tolo or kaleve (Saccharum officinarum), both aboriginal introductions to Polynesia as far east as Hawai'i. Among the dicotyledons, breadfruit, mei (Artocarpus altilis), the Marianas breadfruit (Artocarpus mariannensis), and Tahitian gardenia or tiare Tahiti, tiale or siale (Gardenia taitensis), are all planted in houseyard gardens and could be aboriginal introductions, as could a number of weedy species, such as Asiatic pennywort (Centella asiatica) and Achyranthes aspera, the latter of which could have been introduced as a weed or deliberately as an important medicinal plant. Polynesian bamboo, kaho (Schizostachyum glaucifolium), although considered a recent introduction, could possibly have been introduced to Tuvalu from other parts of Polynesia at some time before European contact.

It is stressed, however, that it is difficult to determine exactly which crops were in fact introduced, either one or more times before European contact, but which, because of the harsh atoll conditions, did not survive and have subsequently been re-introduced, possibly from Samoa, Kiribati, Fiji or other source locations where they grow well. The case of ti (Cordyline fruticosa) is a good example that Seluka (1997) reports: it was used for embalming corpses in the past and was reported to be "very plentiful" in 1898 on Funafuti by Maiden (1904: 551), who indicated that the leaves were used for covering "native ovens" and that "the roots were formerly used much for food on Funafuti," but that "since the introduction of taro and bananas the natives have almost abandoned the cultivation of this plant because of the hard work it entails." Today, ti is well known and is increasingly common in gardens. As with some other plants it could have been introduced by Samoan missionaries in early post-European contact times.

Table 2. Number of vascular plants reported present in Tuvalu by type/use. The types indicate whether species are assumed to be native and the uses indicate whether the introduced species are food and/or multipurpose plants, ornamentals or weeds. An attempt has been made to assign all introduced species to the most appropriate category, although most of the indigenous species are culturally useful multi-purpose species, and many of the introduced food, ornamental and weedy species have multiple uses or values. Ornamentals include species that are used for leis and body ornamentation.

\begin{tabular}{|c|c|c|c|c|c|}
\hline \multirow[t]{2}{*}{ Plant Class } & \multirow[t]{2}{*}{$\begin{array}{l}\text { Indigenous } \\
\text { Species }\end{array}$} & \multicolumn{3}{|c|}{ Cultivated/Introduced Species } & \multirow[t]{2}{*}{ Total } \\
\hline & & Food/Multipurpose & Ornamentals & Weeds & \\
\hline Ferns and Fern Allies & 6 & 1 & 1 & 1 & 9 \\
\hline Gymnosperms & - & - & 2 & - & 2 \\
\hline Monocotyledons & 11 & 23 & 44 & 25 & 103 \\
\hline Dicotyledons & 42 & 75 & 76 & 55 & 248 \\
\hline Total & 59 & 99 & 123 & 81 & 362 \\
\hline
\end{tabular}

\section{ECOLOGICAL AND CULTURAL UTILITY OF TUVALU'S FLORA}

As stressed in the introduction, plants are central to the rich culture of Tuvalu and are a resource that gives Tuvaluans protection against environmental and climate change and economic uncertainties. This is particularly true for the indigenous and long-established introduced species, virtually all of which have great value within the Tuvaluan subsistence economy. Trees, for example, serve a wide range of functions and are used for many purposes. The following list of ecological and cultural services and products provided by forests, trees and associated plants, animals and micro-organisms from Pacific Island agroforestry systems shows the wide importance of trees to the people who live on atolls (adapted from Thaman and Clarke 1993; Thaman 2004; Thaman 2014). 


Ecological Services
Climate Regulation
Shade/UV Protection
Carbon Sequestration
Water Purification
Frost Protection
Water Regulation
Pollution Control/
Refuge
Cultural and Economic S
Timber (commercial)
Timber(subsistence)
Fuelwood
Boatbuilding(canoes)
Sails
Tools
Weapons/Hunting
Containers
Woodcarving
Handicrafts
Fishing Equipment
Floats
Toys
Switch/Whips/Discipline
Mats
Baskets
Cages/Roosts
Tannin
Poisons/Pesticides
Insect Repellents
Deodorants
Embalming Corpses
Lovemaking Sites
Refuges/Safe Havens
Aphrodisiacs

Erosion Control
Flood/Runoff Control
Wind Protection
Coastal Protection
Wave control/reduction
Nutrient Recycling
Soil Improvement
Bioremediation

\author{
Dispersal \\ Pollination \\ Animal/Plant Habitats \\ Spawning/Breeding Grounds \\ Nurseries/Nursing Grounds \\ Wild Animal Food \\ Weed/Pest/Disease Control
}

Prop or Nurse Plants

Staple Foods

Supplementary Foods

Wild/Snack/Emergency foods

Animal Foods/Fodder

Spices/Sauces

Teas/Coffee

Non-alcoholic Beverages

Alcoholic Beverages

Stimulants

Narcotics

Masticants/Chewing Gum

Meat Tenderizers

Preservatives

Brush/Paint Brush

Commercial/Export Products

Abortifacients Fertility Control

Rubber/Elastic

Oils

Toothbrush

Toilet Paper

Fire Making

Secret Meeting Sites

Tourism/Scenic

Table 3 shows the frequency of usage for specified purposes of 140 common coastal littoral and mangrove plant species found in the Pacific Islands. The analysis shows that there are some 75 different purpose/use categories for coastal plants, with the total frequency of usage for 140 plants being 1024, an average of 7.3 purpose/use categories per plant, with only two species having no reported use. Although the study was conducted for all Pacific Islands, from Papua New Guinea in the far west to Hawai'i, Kiribati and Easter Island in the eastern Pacific, data from Tuvalu were also included and the most useful plants in the study are used for many of the same purposes in Tuvalu. 
Table 3. Frequency of usage for specified purposes of 140 Pacific Island coastal plant species by plant type. (Source: Thaman 1992)

\begin{tabular}{|c|c|c|c|c|c|c|c|}
\hline Purpose/Use & $\begin{array}{c}\text { Ferns } \\
\text { (10 spp.) }\end{array}$ & $\begin{array}{c}\text { Herbs } \\
\text { (17 spp.) }\end{array}$ & $\begin{array}{c}\text { Grasses/ } \\
\text { Sedges } \\
\text { (11 spp.) }\end{array}$ & $\begin{array}{c}\text { Vines/ } \\
\text { Lianas } \\
\text { (14 spp.) }\end{array}$ & $\begin{array}{l}\text { Shrubs } \\
\text { (26 spp.) }\end{array}$ & $\begin{array}{c}\text { Trees } \\
\text { (62 spp.) }\end{array}$ & $\begin{array}{c}\text { Total } \\
\text { (140 spp.) }\end{array}$ \\
\hline Medicinal/Health & 6 & 15 & 7 & 11 & 23 & 51 & 113 \\
\hline General Construction & - & - & - & - & 6 & 54 & 60 \\
\hline Body Ornamentation & 6 & 8 & 3 & 7 & 12 & 26 & 62 \\
\hline Firewood/Fuel & - & - & - & - & 8 & 43 & 51 \\
\hline Ceremony/Ritual & 3 & 4 & - & 5 & 6 & 23 & 41 \\
\hline Cultivated/Ornamental & 4 & 3 & - & 2 & 10 & 20 & 39 \\
\hline Tools/Toolmaking & - & - & - & - & 4 & 33 & 37 \\
\hline Emergency/Famine Foods & 4 & 5 & 2 & 2 & 4 & 18 & 35 \\
\hline Boat/Canoe Building & - & - & 1 & - & 3 & 30 & 34 \\
\hline Dyes/Pigments & - & - & - & 2 & 4 & 24 & 30 \\
\hline Magic/Sorcery & 1 & 6 & 1 & 1 & 6 & 14 & 29 \\
\hline Fishing Equipment & - & 1 & 2 & - & 8 & 17 & 28 \\
\hline Cordage/Fiber & 2 & 2 & 2 & 6 & 3 & 10 & 25 \\
\hline Games/Toys & - & - & 1 & 4 & 4 & 16 & 25 \\
\hline Supplementary Foods & 2 & 2 & - & 2 & 3 & 14 & 23 \\
\hline Scenting Oil/Perfumery & 1 & 1 & 1 & 1 & 6 & 11 & 21 \\
\hline Fertilizer/Mulching & 1 & 2 & 2 & 1 & 4 & 11 & 21 \\
\hline Weapons/Traps & - & - & - & - & 6 & 14 & 20 \\
\hline Woodcarving & - & - & - & - & 1 & 18 & 19 \\
\hline Food Parcelization & 3 & 1 & - & 3 & 1 & 11 & 19 \\
\hline Animal Feed & 1 & 4 & - & 3 & 2 & 9 & 19 \\
\hline Legends/Mythology & - & - & - & - & 3 & 15 & 18 \\
\hline Handicrafts & 1 & 1 & 3 & 2 & 1 & 9 & 17 \\
\hline Clothing & - & 1 & 3 & - & 1 & 9 & 14 \\
\hline Musical Instruments & - & - & - & - & 1 & 13 & 14 \\
\hline Cooking Equipment & - & - & - & - & 1 & 12 & 13 \\
\hline Fish Poisons & - & - & - & 3 & 4 & 4 & 11 \\
\hline Export/Local Sale & - & 1 & - & - & 2 & 8 & 11 \\
\hline Adhesive/Caulking & - & 1 & - & 1 & - & 9 & 11 \\
\hline Fire by Friction & - & - & - & - & 1 & 8 & 9 \\
\hline Soap/Shampoo & - & 1 & - & 3 & 3 & 2 & 9 \\
\hline Containers & - & - & - & - & 1 & 7 & 8 \\
\hline Repellents/Fumigants & - & - & - & - & 2 & 6 & 8 \\
\hline Wild Animal Foods & - & - & - & - & 3 & 5 & 8 \\
\hline Tannin/Preservatives & - & - & - & - & 1 & 6 & 7 \\
\hline Antitoxins & - & 1 & - & 1 & 1 & 4 & 7 \\
\hline Living Fences/Hedges & - & 1 & - & - & 1 & 5 & 7 \\
\hline Staple Foods & - & 1 & - & - & - & 5 & 6 \\
\hline Drinks/Beverage & - & 1 & - & 2 & 1 & 1 & 5 \\
\hline Strainers/Filters & - & - & 2 & - & - & 3 & 5 \\
\hline Toilet Paper & - & - & - & - & 1 & 4 & 5 \\
\hline Land Reclamation & - & - & - & - & - & 5 & 5 \\
\hline Calendars/Clocks & - & - & - & - & - & 5 & 5 \\
\hline Contraceptives/ Abortifacients & - & - & - & - & 3 & 2 & 5 \\
\hline Thatching/Roofing & - & - & - & - & 1 & 3 & $\begin{array}{c}4 \\
\text { continued) }\end{array}$ \\
\hline
\end{tabular}


Table 3. Frequency of usage for specified purposes of 140 Pacific Island coastal plant species by plant type. (continued)

\begin{tabular}{|c|c|c|c|c|c|c|c|}
\hline Purpose/Use & $\begin{array}{c}\text { Ferns } \\
\text { (10 spp.) }\end{array}$ & $\begin{array}{c}\text { Herbs } \\
\text { (17 spp.) }\end{array}$ & $\begin{array}{c}\text { Grasses/ } \\
\text { Sedges } \\
\text { (11 spp.) }\end{array}$ & $\begin{array}{c}\text { Vines/ } \\
\text { Lianas } \\
\text { (14 spp.) }\end{array}$ & $\begin{array}{l}\text { Shrubs } \\
\text { (26 spp.) }\end{array}$ & $\begin{array}{c}\text { Trees } \\
\text { (62 spp.) }\end{array}$ & $\begin{array}{c}\text { Total } \\
\text { (140 spp.) }\end{array}$ \\
\hline Illumination & - & - & - & - & - & 4 & 4 \\
\hline Combs & - & - & - & - & - & 4 & 4 \\
\hline Animal Cages/Roosts & - & - & - & - & - & 4 & 4 \\
\hline Oils/Lubricants & - & - & - & - & - & 3 & 3 \\
\hline Brushes & - & - & - & - & - & 3 & 3 \\
\hline Fans & - & - & - & - & - & 3 & 3 \\
\hline Corks & - & - & - & - & - & 3 & 3 \\
\hline Fishing Bait & - & - & - & - & - & 3 & 3 \\
\hline Other Uses* & - & - & 2 & - & 5 & 27 & 34 \\
\hline Total Uses & 35 & 63 & 32 & 62 & 161 & 671 & 1024 \\
\hline No Uses & - & 1 & 1 & - & - & - & 2 \\
\hline
\end{tabular}

If distinct uses within categories (e.g., tools with distinct functions) are counted, the coconut palm, niu (Cocos nucifera), was found to have 125 different uses. Next in order of importance, all with 20 or more reported uses, are Hibiscus tiliaceus (fou fafine), Pandanus tectorius (fala), Calophyllum inophyllum (fetau), Cordia subcordata (kanava), Guettarda speciosa (pua), Scaevola taccada (gasu), Pemphis acidula (gie), Thespesia populnea (milo), Rhizophora spp. (togo), Tournefortia argentea (tausunu), Casuarina equisetifolia (lakau Kilisimasi), Premna serratifolia (valovalo), Morinda citrifolia (nonu), Pipturus argenteus (fou tagata), Terminalia catappa (kunikuni) and Ficus tinctoria (felo) (Table 4). All of these species are recorded present, as either native or introduced species in Tuvalu. Another 16, all of which are found on Tuvalu, have at least 7 uses each (Table 4). Moreover, the list does not include the more strictly ecological functions of coastal plants discussed above, such as shade, protection from wind, sand and salt spray, erosion and flood control, coastal reclamation and animal and plant habitats, all of which are of increasing importance to the people of Tuvalu.

With specific reference to Tuvalu, preliminary analyses of available data indicate that there is a similar range of traditional uses for the 59 indigenous species reported present in Tuvalu and wide usage for many of the introduced species, the majority of which are ornamentals or food plants. This is a clear indication of the value of both indigenous and introduced plants to the people of Tuvalu; however, many traditional uses have lapsed or been replaced by commercial products or technology, unless emergencies require them. Modern medicine, clothing, fishing lines, matches, crockery, plastic bags, soap, imported food and drinks, snack foods and emergency food rations (food aid), and imported timber, plastics and metal have, for example, replaced many traditional plant-derived products. Moreover, many of the current generation, schooled in the modern educational system and living in the cash economy, often know few of the traditional uses of plants, let alone their vernacular Tuvaluan names. This loss of knowledge has undoubtedly contributed to a loss of appreciation for, and indirectly to the degradation of, the indigenous and long-established vegetation and flora of Tuvalu.

Of particular concern, particulary in urban Funafuti, is the abandonment or reduced consumption of traditional food and beverage crops, such as the coconut palm (e.g., coconut meat, cream, juice and toddy), pandanus, breadfruit and bananas, and their replacement by highly refined imported foods such as sugar, white rice and flour, cookies, biscuits and candy, noodles, canned fish, soft drinks, alcohol, tea and coffee. In the Pacific Islands, this dietary shift has led to unprecedented levels of food dependency and some of the highest, or most rapidly increasing, incidences in the world of vitamin and mineral deficiency and nutrition-related diseases. Diseases such as iron-deficiency anaemia, vitamin-A deficiency-induced 
night blindness, diabetes, cardiovascular disease, hypertension and stroke, gout and hyperuricaemia, some forms of cancer and dental disease, which were rarely encountered in the past, are now serious causes of morbidity and mortality in the rapidly urbanizing atoll countries (Thaman 1988). As stressed above, the promotion of the planting and consumption of fresh food crops has been a major priority of many of the agriculture initiatives in Tuvalu over the past 20 years.

Table 4. Coastal plant species of particular cultural utility based on the number of different uses in Pacific Island countries, not including ecological functions and services. An asterisk (*) indicates a species is present in Tuvalu, but probably as a non-indigenous introduced species. Source: Thaman 1992.

\begin{tabular}{|c|c|c|}
\hline Scientific Name & $\begin{array}{l}\text { Tuvaluan } \\
\text { Name(s) }\end{array}$ & $\begin{array}{l}\text { Number } \\
\text { of Uses }\end{array}$ \\
\hline Cocos nucifera & niu & 125 \\
\hline Hibiscus tiliaceus & fou fafine & 57 \\
\hline Pandanus tectorius & fala & 53 \\
\hline Calophyllum inophyllum & fetau & 43 \\
\hline Cordia subcordata & kanava & 40 \\
\hline Guettarda speciosa & pua & 36 \\
\hline Scaevola taccada & gasu, gahu & 32 \\
\hline Pemphis acidula & gie & 30 \\
\hline Thespesia populnea & milo & 26 \\
\hline Rhizophora spp. & togo & 25 \\
\hline Tournefortia argentea & tausunu, tauhunu & 23 \\
\hline Casuarina equisetifolia* & lakau Kilisimasi & 22 \\
\hline Premna serratifolia & valovalo & 22 \\
\hline Morinda citrifolia & nonu & 22 \\
\hline Pipturus argenteus & fou tagata & 21 \\
\hline Terminalia catappa* & kunikuni & 21 \\
\hline Ficus tinctoria & felo & 21 \\
\hline Hernandia nymphaeifolia & puka vaka & 18 \\
\hline Lumnitzera littorea & sagale & 17 \\
\hline Pisonia grandis & puka vai & 17 \\
\hline Barringtonia asiatica & futu & 14 \\
\hline Cycas circinalis* & laupama & 13 \\
\hline Gardenia taitensis* & tiale & 12 \\
\hline Sida fallax & akatā & 11 \\
\hline Triumfetta procumbens & tolotolo & 11 \\
\hline Vitex trifolia* & $?$ & 11 \\
\hline Clerodendrum inerme & inato & 10 \\
\hline Cassytha filiformis & fetai & 10 \\
\hline Tacca leontopetaloides* & vatia & 10 \\
\hline Crinum asiaticum & tapua, talotalo & 9 \\
\hline Microsorium grossum & maile & 8 \\
\hline Ochrosia oppositifolia & fao & 8 \\
\hline Ipomoea pes-caprae & fue & 7 \\
\hline
\end{tabular}




\section{PLANT NAMES AND THE TUVALUAN LANGUAGE}

To understand Tuvalu's flora and vegetation and to record and protect the names, language and knowledge related to plants and their uses, it is necessary to understand the orthography (alphabet and its use) and the diversity of dialects and variations within Tuvaluan, the language of Tuvalu. Tuvaluan is a Western Polynesian language that is most closely related to Tokelauan (from the atolls of Tokelau to the east) and Samoan, as well as to Tongan, particularly on the northern atolls of Nanumea and Nanumaga, which had early contacts with Tonga. In the case of Nui Atoll, although the atoll is geographically and politically within the Tuvalu group, the culture and language is essentially I-Kiribati. The resultant diversity of Tuvaluan plant names clearly reflects both the diverse origins of the language itself and historical relationships that Tuvaluans have had with other Pacific Island cultures and their colonial and post-colonial partners.

The Tuvaluan alphabet has 16 letters, including five vowels-a, e, i, $\mathbf{o}$ and $\mathbf{u}$-and 11 consonants-f, $\mathbf{g}, \mathbf{h}, \mathbf{k}, \mathbf{l}, \mathbf{m}, \mathbf{n}, \mathbf{p}, \mathbf{s}, \mathbf{t}$ and $\mathbf{v}$. All vowels can be used either as a single, short vowel, or a lengthened vowel, making them sound like a double vowel, which is indicated by putting a macron over the letter, as in $\overline{\mathrm{a}}$, $\overline{\mathrm{e}}$, $\overline{1}, \bar{o}$ and $\bar{u}$. Lengthened vowels are, however, sometimes also written as double vowels, rather than using the macron, as in aa or oo instead of ā or o (Jackson 2001).

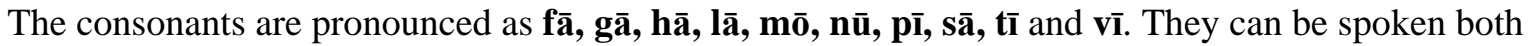
softly or stressed, although the $\mathbf{g}$ is pronounced as a soft $\mathbf{n g}$, like in the words "sing" or "singer," rather than as a hard g, like in the words "garage" or "gate." In the past ng was often used to indicate this sound, as is currently the practice in Tongan and the Kiribati language, with place names, such as Nanumaga, written as Nanumanga in the past. Today, however, Tuvalu follows the system currently used in Samoa, Tokelau and Fiji, where $\mathbf{g}$ is used instead of $\mathbf{n g}$ (Jackson 2001).

Finally, although vowels can be used alone (e.g., $\overline{\mathbf{a}}$, a fence or pen, and $\mathbf{i}$, meaning in or at), or two or more different vowels used together (e.g. kaiao for fertilizer or mulch), in all cases all vowels, whether shortened or lengthened, or when combined together, should be pronounced distinctly (i.e., the letters uai are pronounced like "oo why" in English). Consonants, however, cannot stand alone, cannot end a sentence, and must always be followed by a vowel (e.g., mouku, "weed or grass" or lakau, "tree or shrub"), except in some cases where words have been borrowed directly from Kiribati (e.g., akanta, for the plant bougainvillea) or if they are words from Nui.

In terms of linguistic diversity, there are several dialects in Tuvalu, with each island having some expressions and plant names that are unique to a given atoll or groups of atolls. The main differences are between the southern islands of Nukulaelae, Funafuti, Vaitupu and Nukufetau, and the northern islands of Nanumea, Nanumaga and Niutao (i.e., southern and northern dialects). In Nanumea and Nanumaga there is considerable Tongan affinity in the language, with plant names being more closely related to Tongan names in terms of spelling, with Nanumea using an $\mathbf{h}$ rather than an $\mathbf{s}$, and a $\mathbf{t}$ rather than an $\mathbf{s}$ in some cases. For example, in Nanumea, the plant names are gahu instead of gasu or tauhunu instead of tausunu for Scaevola taccada and Tournefortia argentea, respectively, or tiale instead of siale for Tahitian gardenia (Gardenia taitensis). There are also distinct names for different species. For example, whereas puka vai refers to Pisonia grandis in Funafuti, it refers to Hernandia nymphaeifolia on Nanumea (where it is additionally known as puka faivaka), whereas H. nymphaeifolia is known in Funafuti as puka vaka.

Also, the close historical links with Samoa, Kiribati, Nauru and Fiji during Tuvalu's colonial history, as well as increasingly regular shipping and air services from these destinations, have meant that there has been considerable influence of these languages on Tuvaluan plant names, with many names being Tuvaluanizations of names from these areas. For example, Samoa pastors (faifeau) have been placed in Tuvalu since the 1860s and along with Samoan traders reportedly introduced a number of plants, such as crinum lily (Crinum asiaticum), common hibiscus (Hibiscus rosa-sinensis), and some banana cultivars, many of which bear Samoan or Tuvaluanized Samoan names. The impact of the Kiribati language, in addition to its influence on Nui Atoll, is also considerable. For almost a century, Tuvalu was a part of the British Gilbert and Ellice Island Colony (GEIC), and particularly since World War II, many Tuvaluans worked in the GEIC government in Tarawa and intermarried with I Kiribati. And for over half a century 
Tuvaluans worked alongside I-Kiribati in the phosphate mines of Nauru and Banaba (which is part of Kiribati), from which they undoubtedly brought plants and/or plant names. Finally, the long colonial and economic ties with Fiji, and the resettlement of a large percentage of the people of Vaitupu Atoll to Kioa Island in Fiji in the 1940s, have also strengthened these links.

As a result, many plant names are Tuvaluanized versions of Kiribati, Nauruan, Fijian or other nonTuvaluan plant names. For example, Tuvaluan names borrowed directly from Kiribati include inato from te inato (Clerodendrum inerme), kaipauni from te kaibaun (Russelia equisetiformis), kaipuaka from te kai buaka for lantana (Lantana camara) and nikilailai from nei karairai for yellow bells (Tecoma stans), the last three of which are long-established plants used in garlands.

Finally, as stressed above, the language and culture of Nui Atoll are basically I Kiribati, although some names are different than the names in Kiribati or are Tuvaluanizations of the Kiribati names (e.g., the substitution of $\mathbf{I}$ for $\mathbf{r}$ in the Kiribati name for Guettarda speciosa, te uri, making it uli in Tuvalu). Although it has not been possible to record the Nui names for most plants, when available (e.g., in Woodroffe 1991), these have been listed and credited.

Although the local vernacular plant names in this study are mainly from people on Funafuti and Nanumea, the northernmost island, other names were obtained from informants on Funafuti, sometimes without knowing their exact origins, and from published accounts, including the Tuvaluan Dictionary (Jackson 2001) and Seluka's 1991 study. The sources for unique or differing names are cited along with the names in the annotated systematic list of species.

\section{CONCLUSION}

As stressed in the introduction, the vegetation and flora of the atolls of Tuvalu are among the poorest and most degraded and disturbed in world. Limited land area and habitat diversity, a long settlement history, over a century of the expansion of coconut plantations onto almost all available land, land clearance and excavation of the soil in extensive areas for bases and airstrips during World War II, rapid post-independence urbanization and a long history of plant introductions have produced one of the most highly modified floras in the world.

Despite the degradation, the 300 or so plant species that still survive in Tuvalu are the only plants that the people there have to satisfy many of their most important cultural, economic and environmental needs. Almost all plants, even weeds, have a value, often for timber (laupapa), garlands (fou, ula or sisi), scenting coconut oil or perfume (sinu or sausau), medicine (vai lakau) or for mulch (kaiao). Unfortunately, many of Tuvalu's most important indigenous plants and many important traditional medicinal plants are uncommon or rare and in need of some form of protection or re-establishment if the next generation is to learn about them, protect them, and to continue to receive their many benefits. This work attempts to record important information for the people and children of Tuvalu and other interested readers, and to better understand the vegetation and flora as perhaps the most important basis for sustainable atoll life in an uncertain future. Without plants, the atoll world of Tuvalu would be impossible to live in. Without a young generation that knows the names and value of plants, many more important plants will undoubtedly be neglected, degraded and disappear from the twenty-first century landscape of Tuvalu. It is the author's hope that this report will help people to realize that, regardless of money, education or political power, the plants of Tuvalu continue to be perhaps the most important foundation for the cultural, economic and environmental survival of present and future generations in the face of an uncertain future of climate, environmental, social and economic change. 


\section{ANNOTATED SYSTEMATIC LISTING OF THE VASCULAR PLANTS OF TUVALU}

This annotated systematic listing of the vascular flora of Tuvalu is based on past studies and updated after the most recent visit to Tuvalu by the author in March 2016. It consists of a listing of, and relevant information on, all native and introduced vascular plant species that have been reported present at some time in Tuvalu, with particular emphasis on Funafuti, the national capital and most populous and most studied of the nine atoll islands of Tuvalu. It begins with Pteridophyta (ferns and fern allies), followed by Gymnosperms and then Angiosperms. Within Angiosperms, Monocotyledons precede Dicotyledons. Under these headings individual families are listed in alphabetical order (e.g., Acanthaceae, Amaranthaceae, Anacardiaceae, etc.), with individual species within each family listed in alphabetical order by genus (e.g., Achyranthes aspera, Achyranthes canescens, Alternanthera brasiliana, etc.).

Under each species entry the types of information and order of presentation are as follows: (1) most widely accepted Latin or scientific name; (2) synonyms for the Latin or scientific names; (3) common English names or other well-known common names; (4) local vernacular Tuvaluan names; (5) origin or antiquity status of the species (i.e., whether it is indigenous, an aboriginal pre-European introduction or a recent introduction into Tuvalu), including the geographical origin or native range of the species; (6) abundance or frequency of occurrence, (i.e., its “conservation status”); (7) brief descriptions of some species, including habitat preference or reported distribution in Tuvalu including selected geographical locations and uses or cultural utility or knowledge associated with the species; (8) references to previous published records of the species and indication of the persons who have recorded, reported or collected a given species, including numbers corresponding to herbarium specimens; and (9) numbers corresponding to digital photos of the species and its vegetation associations taken by the author. This information, its organization and the symbols and conventions used under each category are explained further below.

\section{Family Names}

Family names (e.g., POLYPODIACEAE, ACANTHACEAE or RUBIACEAE) are centered in bold capitals immediately before the first species entry in each family.

\section{Latin/Scientific Names}

The first name listed in bold italics font is considered to be the currently most widely accepted published Latin binomial for a given species (usually the earliest published name or basionym), although many names have been revised or corrected and republished. All names follow the International Code of Botanical Nomenclature and most have been checked against The Plant List: A Working List of All Plant Species (2013, http://www.theplantlist.org).

The name(s) or the abbreviation of the name(s) of the authority or authorities (persons responsible for describing and publishing a given species name) are provided after each species name. For example, Allium sativum L. indicates that the species was first described and published by Linnaeus (L.), whereas

Proiphys amboinensis (L.) Herbert indicates that the species name was first published by Linnaeus (L.) but was later revised, renamed and republished by Herbert.

Additional scientific names provided include Latin binomial synonyms or older names no longer in use for the species, and, in some cases, incorrect names commonly applied to the species, which are indicated by sensu auct. non.

\section{Common Names}

English or common vernacular names for a species and other widely used names (e.g., coconut palm) are listed below the Latin name. 


\section{Tuvaluan Names}

Vernacular Tuvaluan names, when available, are provided after the common English names. In some cases literal translations of the meaning of the Tuvaluan names are provide in quotation marks. A question mark (?) designates an unverified or doubtful name.

The Tuvaluan names are based mainly on information gathered between 1993 and 2010 from local informants and from more in-depth interviews and field visits with the main informants and contributing authors. Names from Funafuti Atoll are indicated by the abbreviation (Ff), from Nanumea by (Nm), from Niutao by (Nt), from Nui by (Nui) and from Vaitupu by (Vt).

The parenthetical abbreviation (TvD) — with a capital "D" —indicates that a name was recorded with a clear indication of what species it might refer to in the Tuvaluan Dictionary (Jackson 2001). For example, the dictionary defines "gie (n.)" as a "hardwood tree that thrives in swamping inland areas [cf. gigie]," which clearly indicates that it is Pemphis acidula. Alternately, the abbreviation (Tvd) — with a lowercase "d" indicates that the name was recorded without information identifying the exact species, with most entries saying "type of plant"; few if any plant names in the dictionary include scientific names or clear descriptions of a given plant, its habitats or its uses.

Sources are cites when names are different than the names given by the main informants in the current study (e.g., those provided by Koch [2002] for Niutao or by Woodroffe [1991] for Nui and other islands), for names with unspecified island locations by Seluka (1997), and for names from any other sources.

\section{Antiquity Status}

Antiquity status indicates whether a given species is presumed to be indigenous to Tuvalu; an aboriginal introduction by Tuvaluans or other indigenous Pacific Islanders before European contact; or a post-European contact introduction. In some cases, it is suggested that a species may have been successfully introduced prior to European contact, but either not successfully established or brought to local extinction before botanical collections or observations of the flora were made. The question mark (?) indicates that the true status of a species is in doubt (i.e., whether it is really indigenous or an aboriginal or recent introduction).

Antiquity status includes a description of geographical origin. Geographical origin refers to what seems to be the original natural distribution of a given species before humans began to acts as dispersal agents for plants. In many cases it is difficult to be sure what the original pre-human or pre-European contact range of a given species was because species introduced either deliberately or accidentally by the Pacific Island colonizers of the islands have often become naturalized and integral components of what now seems to be indigenous or wild vegetation. In most cases the geographical origins of species are based on Whistler (1980, 1992, 1995, 2000a).

With respect to terminology, Malesia (sometimes confused with the country Malaysia) is a biogeographical term referring to an area encompassing the tropical islands of Indonesia, Malaysia, Philippines, the island of New Guinea and Taiwan; Indo-Malaysia refers to an area encompassing the Indian Ocean and Malesia; Indo-Pacific refers to an area extending from the Indian Ocean to the islands of the Central Pacific; Paleotropics refers to the Old World tropics including tropical Africa, Asia and the tropical Pacific Islands; pantropical indicates that a species is found throughout the Old World (Asian and African) and the New World (South and Central American) tropics; and cosmopolitan indicates that a species is found almost worldwide. In some cases (usually in the cases of easily dispersed weedy pioneer species) information is provided on both the assumed original distribution and whether a species is now more widespread (e.g., pantropical).

\section{Abundance or Frequency Occurrence (Conservation Status)}

The estimates of abundance or frequency occurrence, or whether a given species is now endangered or locally extinct, are based on in-the-field observations by the author and a combination of the knowledge of Tuvaluan informants and published accounts, most importantly Woodroffe's "Vegetation of Tuvalu” (1991). 
The categories used to indicate the abundance of a given species are:

Extirpated - Reported present in the past, but not seen during more recent surveys and now possibly extirpated (locally extinct) in Tuvalu, though still found, and in many cases abundant, on other islands of the Pacific or in other parts of the world.

Rare - Seen present in only one or two locations and possibly in danger of extirpation (local extinction) or is a rare ornamental, food plant, etc., that may be past or recent trial introductions, and not really well suited to the atoll environment.

Uncommon - Found present in only a few locations, such as in the relatively few undisturbed sites, as a remnant in settled areas or in a few houseyard gardens and experimental agricultural areas. This category could also pertain to those plants, such as annual flower or food plants, that are seasonally planted, but which were not seen or not common during the period of the survey.

Occasional - Occasionally seen in a number of places, or locally common in only a few locations.

Common - Present in a number of locations, but not really dominant, or locally common or abundant in some locations.

Abundant - Widespread in a range of habitats or dominant in a number of different habitats throughout the island.

Very abundant - Abundant in most habitats and found as a dominant in many sites or habitats.

\section{Remarks}

For some species brief descriptions are provided along with information on habitat preference. The descriptions are mainly adapted from Whistler (1980, 1992, 1995, 2000b) and based on the author's perception, and the habitat preference is based on in-the-field observation by the author.

Ethnobotanical information (including vernacular names) on uses or cultural utility of the individual plant species is based on surveys by the author between 1991 and 2016 as well as on published accounts, mainly those of Hedley (1896), Maiden (1904), Koch (1983, 2002), Thaman and Whistler (1996), Whistler (1991, 2000a, 2009), Seluka (1997) and Thaman, Fihaki and Fong (2013). There is an urgent need for ethnobotanical information to be recorded more thoroughly and systematically to ensure the remaining knowledge of older Tuvaluan people is not lost.

\section{Citations, Collectors and Herbarium Specimens}

All citations from Funafuti Atoll prior to the current study initiated by the author in 1991 and citations from other atolls are based on collections cited in Woodroffe's (1991) "Vegetation of Tuvalu." For the species included in the list, studies/collectors who recorded the presence of a species are cited using the following abbreviations:

CH 1896 — Presence supported by collections by C. Hedley (1896)

JHM 1904 — Presence supported by J.H. Maiden's (1904) citations of collections made by Halligan and Finckh in 1898 and David (1899)

KF 1987 — Presence supported by undeposited specimens of K. Fitchett (1987) in lieu of no other previous records.

PAM 1989 — Presence supported by undeposited specimens by P. A. Maddison (1989) in lieu of no other previous records.

CDW 1991 — Presence supported by C. D. Woodroffe (1991)

RRT 1991 — Presence supported by sight records or collections made by Thaman (1991), with voucher specimen numbers listed in parentheses

RRT and WAW 1993 - Presence supported by sight records by Thaman and Whistler in September 1993, with voucher specimen numbers in parentheses

SS 1997 — Species listed by Seluka in the "Vegetation and Flora" section of his work Traditional, Current and Potential Uses of Forests, Trees \& Other Plants of Tuvalu

GK 2002 — Records reported by Gerd Koch (2002) based on his studies on Niutao in 1963 
RRT 2003 - Sight records, most with supporting digital photos taken by Thaman in 2003, the numbers of which are listed for each species

T, F \& F 2010 - Sight records by R. Thaman, T. Fong and E. Fihaki in 2010, documented in almost all cases by digital photos

RRT 2016 — Sight records by R. Thaman in March 2016, again documented with digital photos

\section{Digital Photographs}

The last entries under each species are the reference numbers of the digital images/photos taken to document, validate the presence of and/or to help confirm the identity of a given species. The photos with the prefix DPTV are digital photos taken by mainly RRT during visits in 2003 and 2010, and those with the prefix DSC are recent photos taken in March 2016. A number followed by a lowercase letter, such as a, b or c, indicates the position of the given species in a photo with sometimes as many as five species pictured together. The digital photos/images have been copied onto computer files and have been lodged in the South Pacific Regional Herbarium at the University of the South Pacific, Suva, Fiji, the University of the South Pacific Campus in Funafuti, Tuvalu and the Environment Department in Funafuti, Tuvalu.

\section{PTERIDOPHYTA (FERNS AND FERN ALLIES)}

\section{ASPLENIACEAE (SPLEENWORT FERN FAMILY)}

\section{Asplenium nidus L.}

Common Name: bird's-nest fern

Tuvaluan Names: katafa, laukatafa (Ff, Nm; Tvd); laulü (name of the young leaves when cooked as a spinach) (Ff, Nm; Tvd); laukatapa? (Nui; Woodroffe 1991)

Status: Indigenous. Paleotropical.

Abundance: Common.

Remarks: Found as an epiphyte and more commonly as a terrestrial fern in abandoned or poorly maintained coconut plantations, secondary forest and inner coastal littoral forest. Rare on Fogafale Islet, but common to very abundant on the uninhabited islets of Funafuti Atoll such as Tepuka, Tefala, Fualopa and Fuakau. Occasional as a planted ornamental or pot plant. Reported present on all eight atolls in Tuvalu. Young leaves and shoots cooked as one of the few locally available green vegetables (laulū) and considered a delicacy. Leaves also used as plates for food.

Recorded: CH 1896; JHM 1904; CDW 1991; RRT 1991; RRT \& WAW 1993; SS 1997; RRT 2003; T, F \& F 2010; RRT 2016

Voucher Photographs: DPTV0717, 0719, 0720, 0721, 0750, 0755, 0765, 0796, 0798, 0822, 0851a, 0857, 0858, 1059, 1060, 1061, 1062a, 1068a, 1069, 1074, 1117, 1118, 1119, 2877, 2977, 2978, 3102, 3112, 3113, 3114b, 3116b, 3117b, 3118b, 3124a, 3126b, 3136, 3139, 3140, 3156, 3160, 3215, 3216, 3220, 3231, 3231, 3239, 3240, 3241, 3243, 3244, 3245, 3246, 3249

\section{Azollaceae (WATER FERN FAMILY)}

Azolla pinnata $\mathrm{R}$. Br.

Synonyms: Azolla imbricata (Forst.) Nakai; Azolla pinnata var. imbricata (Forst.) Bonap.

Common Names: ferny azolla, feathered waterfern

Status: Recent introduction. Paleotropics and subtropics and to Australia, New Caledonia and New

Zealand.

Abundance: Rare or now extirpated.

Remarks: Reported present on Funāfitu as Azolla sp. by Seluka (1997). Probably introduced as a natural fertilizer, because of its ability to take advantage of the nitrogen-fixing abilities of symbiotic blue- 
green algae (cyanobacteria). Could possibly have been another common species, red azolla (Azolla filiculoides Lam.).

Recorded: SS 1997

\section{NEPHROLEPIDACEAE (SWORD FERN FAMILY)}

Nephrolepis acutifolia (Desv.) Christ

Common Names: sword fern, fishtail fern

Tuvaluan Name: sulufe (Ff; Tvd); hulufe, paka (plant), laukimoa (fronds) (Nm; Tvd)

Status: Indigenous. Pantropical.

Abundance: Abundant.

Remarks: Found in colonies and dense populations as an understorey species in coconut plantations, shady inland secondary forest, and occasional in lagoon coastal vegetation; occasional as a planted ornamental. Common on the east end of Tepuka Islet. Fronds used in head garlands (fou), leis (ula) and waist garlands (titi) and as house decoration. Dried leaves used as a mulch or fertilizer. Pinnules or midribs of fronds smoked as a cigarette substitute, mainly by fishermen. Reported present by Maiden (1904) and Maddison (1989) and from all atolls in Tuvalu by Woodroffe (1991).

Recorded: JHM 1904; RRT 1991 (24318); RRT \& WAW 1993 (24174); SS 1997; RRT 2003; T, F \& F 2010; RRT 2016

Voucher Photographs: DPTV0524b, 0560, 0724, 2050, 1072, 1073, 2856, 2875, 3118a, 3119, 3120, 3121, 3124a, 3125, 3126a, 3137, 3158, 3159

Nephrolepis exaltata (L.) Schott

Common Name: Boston fern

Status: Recent introduction. Pantropical.

Abundance: Rare.

Remarks: Seen as an ornamental potplant in 1991 and 2003. Possibly still present as an ornamental. Also reported by in Maiden (1904) on Funafuti, but possibly a miss-identification of N. acutifolia.

Recorded: JHM 1904; RRT 1991; RRT 2003

Nephrolepis hirsutula (Forst. f.) Presl

Synonyms: Polypodium hirsutulum Forst. f.; Nephrodium gibbosum (Willd.) Gaud.; Aspidium gibbosum Willd.

Common Names: sword fern, fishtail fern

Tuvaluan Names: sulufe (Ff; Tvd); mutie? (Nt)

Status: Indigenous. Indo-Pacific.

Abundance: Uncommon.

Remarks: Fern in wasteplaces and houseyard gardens in Vaiaku, Fogafale Islet. Leaves used in garlands and for decoration. Reported present on Funāfuti by Seluka (1997). Also reported from Niutao in 1963 by Koch (1983) and from Vaitupu by Woodroffe $(1981,1985)$. Fronds used in leis and garlands and as house decoration. Dried leaves used as mulch or fertilizer. Often confused with Nephrolepis acutifolia or with Nephrolepis saligna Cass., which was reported present on Nui and Vaitupu by Woodroffe (1991).

Recorded: SS 1997; T, F \& F 2010; RRT 2016

Voucher Photographs: DPTV2108, 2149, 2150, 2151, 2152

\section{POLYPODIACEAe (COMMON FERn FAMILY OR POLYPODY FERN FAMILY)}

Microsorum grossum (Langsd. and Fisch.) S.B. Andrews Synonyms: Phymatosorus grossus (Langsd. \& Fisch.) Brownlie; Polypodium grossum Langsd. \& Fisch. Misapplied Names: Phymatosorus scolopendria (Burm.f.) Pichi-Serm.; Polypodium scolopendria Burm.f.; Phymatodes scolopendria (Burm.) Ching; Microsorum scolopendria (Burm.) Copel.; Polypodium phymotodes L. 
Common Names: scented fern, lawai fern

Tuvaluan Name: maile (Ff, Nm, Nt; Tvd)

Status: Indigenous. Paleotropical.

Abundance: Common.

Remarks: Terrestrial and epiphytic fern in coconut plantations, on the bases of coconut palm trunks and in the coastal strand vegetation, particularly on uninhabited islets, and occasional as a planted ornamental. Much more common in the past. An important cultural plant on all atolls in Tuvalu but becoming rare on Fogafale Islet. Fronds used in head garlands (fou) and in waste garlands (titi), or worn around the neck or arms and the chopped leaves are used to scent coconut oil (sinu). Leaves are used to wrap fish for cooking in the earthen oven. The plant is also used medicinally and in black magic and for embalming corpses in the past (Seluka 1997).

Recorded: CH 1896; JHM 1904; RRT 1991; RRT \& WAW 1993; SS 1997; RRT 2003; T, F \& F 2010; RRT 2016

Voucher Photographs: DPTV0524a, 0610, 0741, 1062b, 1068b, 2539, 2744, 2779, 2983, 3197b, 3198b, 3264

\section{Psilotaceae (Psilotum FAMily)}

Psilotum nudum (L.) Beauv.

Common Names: psilotum, reed fern, wehisk fern

Tuvaluan Names: sai (Ff); pōatua (Nt); silotau (Seluka 1997); fulukimoa (Maiden 1904)

Status: Indigenous. Tropics and subtropics.

Abundance: Rare to uncommon.

Remarks: Occasional near rotten coconut logs on lagoon side of the borrow pits on the north end of Fogafale Islet in the 1990s. Reported present by Hedley (1894) and Maiden (1904). Now rare or endangered and not seen since 1993 on Funafuti. Reported present on Nanumea, Nui, Vaitupu and Nukulaelae in Woodroffe (1991). Koch (2004) reports that the plants are used on Niutao as fans or whisks in the bush and finely chopped and put in coconut oil as a love spell; Seluka (1997) reports its use in black magic and for decoration.

Recorded: CH 1896; JHM 1904; RRT 1991 (24314); RRT \& WAW 1993 (24164); SS 1997

\section{PTERIDACEAE (BRACKEN OR BRAKE FERN FAMILY)}

Pteris tripartita Sw.

Common Names: lacy fern, giant bracken fern, sword brake

Tuvaluan Names: laukisikisi (Vt); lautolo (Seluka 1997); lakau sauga? (Maiden 1904)

Status: Indigenous. Paleotropical.

Abundance: Uncommon.

Remarks: Reported present by Maiden (1904) and seen in a number of houseyard gardens and in taro gardens on Fogafale Islet, but reportedly more common on other atolls. Also reported present on Nui and Vaitupu by Woodroffe (1991). Leaves used as mulch, fronds tied together to making garlands (ula or napenape), to cool fresh toddy while it is being collected and to catch tuna.

Recorded: JHM 1904; CDW 1991; RRT 1991; RRT \& WAW 1993; SS 1997; RRT 2003; T, F \& F 2010; RRT 2016

Voucher Photographs: DPTV0528, 0705, 1130, 1136, 2212, 2213, 2217, 3400

\section{THELYPTERIDACEAE (MARSH FERN FAMILY)}

Sphaerostephanos invisus (Forst. F.) Holtt.

Tuvaluan Names: sulufe (Ff)

Status: Recent introduction. Indo-Pacific from East Africa to Solomon Islands, Fiji and possibly other Pacific Islands. 
Abundance: Rare.

Remarks: Terrestrial fern seen as either a deliberately planted ornamental or accidental introduction with the landscaping in the front of the new Tuvalu Government Building in Vaiaku in 2010 and 2016. Could possibly escape to become invasive.

Recorded: T, F \& F 2010; RRT 2016; RRT 2016

Voucher Photographs: DPTV2508, 2509, 2510, 2511, 2512, 2513, 2514, 2515, 2516a

\section{GYMNOSPERMAE (GYMNOSPERMS)}

\section{ARAUCARIACEAE (ARAUCARIA FAMILY)}

Araucaria columnaris J.R. Forst.

Common Names: Cook pine, Cook araucaria, New Caledonia pine

Tuvaluan Name: lakau Kilisimasi ("Christmas tree”); paina (“pine tree”; Tvd)

Status: Recent introduction. New Caledonia.

Abundance: Uncommon.

Remarks: A tall, attractive, columnar, slightly leaning Christmas-tree-like tree which is commonly planted as an ornamental tree in warm temperate climates. Seen first in 2003 as two beautiful young trees planted in front of the Vaiaku Lagi Hotel on Fogafale Islet, and as more mature trees in 2010 and in 2016. A couple other mature trees are present in roadside gardens on Fogfale Islet. It is often confused with the Norfolk Island pine, Araucaria heterophylla (Salisb.) Franco which is wider spreading, normally does not lean and, when young, is hard to distinguish from A. columnaris.

Recorded: RRT 2003; T, F \& F 2010; RRT 2016

Voucher Photographs: DPTV0881, 0882, 2079a, 2079b, 2098, 2099; DSC03211

\section{CYCADACEAE (CYCAD FAMILY)}

Cycas rumphii Miq. Synonym: Cycas circinalis L.

Common Names: cycad, sago palm, king sago

Tuvaluan Name: laupama ("palm leaf”; Ff, Nm)

Status: Recent introduction. India to Guam.

Abundance: Common.

Remarks: Planted ornamental. Some very large old individuals seen near the main square between the airport and the Vaiaku Lagi Hotel and in houseyard gardens and other areas; planted in the Teone Catholic

Church front yard in north Fogafale in 2016. Fronds used for ornamentation, for making garlands and as leaves for use during Palm Sunday celebrations; smaller young leaves used in garlands by young girls.

Toxic seeds processed into flour used a famine food in other areas of the Pacific where cycads are native.

Recorded: RRT 1991; RRT \& WAW 1993; RRT 2003; T, F \& F 2010; RRT 2016

Voucher Photographs: DPTV0656, 0887, 0950, 0957, 2075, 2833, 2834; DSC03296

\section{ANGIOSPERMAE}

(ANGIOSPERMS)

\section{MONOCOTYLEDONAE}

(MONOCOTYLEDONS) 


\section{Agavaceae (Agave Family)}

Aloe vera (L.) Burm. f.

Synonymn: Aloe barbadensis Mill.

Common Name: aloe vera

Tuvaluan Name: alovela (Ff)

Status: Recent introduction. Southwest Arabia and North Africa.

Abundance: Rare.

Remarks: Planted in PRAP experimental nursery in 1991, but not seen subsequently. Occasionally planted in pots and houseyard gardens to treat burns and other skin ailments.

Recorded: RRT 1991

Cordyline fruticosa (L.) A Chev.

Synonyms: Cordyline terminalis (L.) Kunth; Taetsia fruticosa (L.) Merr.

Common Names: cordyline, ti-plant

Tuvaluan Names: ti (Ff, Nm); lauti (Ff)

Status: Aboriginal introduction? Tropical Asia and a pre-European contact introduction into Polynesia as far east as Hawai'i and possibly a pre-European contact aboriginal introduction into Tuvalu.

Abundance: Common.

Remarks: Planted ornamental in houseyard gardens. A number of red and green leaved cultivars exist. Leaves used for garlands, dancing skirts (titi), and special ornamental sashes (napenape) from Nanumea, and other body ornamentation; to wrap food for cooking in the earthen oven (umu) and, in the past, for embalming corpses. Reported to be "very plentiful" in 1898 by Maiden (1904) and that the leaves "used to be used for covering up the native ovens" and that "the roots were formerly used much for food on Funafuti", but that "since the introduction of taro and bananas the natives have almost abandoned the cultivation of this plant because of the hard work it entails." An important secondary food source, emergency food and source of "sugar" in the past throughout much of the Pacific, where the tuberous root was cooked in an earthen oven for up to three days or more (Whistler 2009).

Recorded: JHM 1904; RRT 1991; RRT \& WAW 1993; SS 1997; RRT 2003; T, F \& F 2010; RRT 2016 Voucher Photographs: DPTV0903, 2202, 2518

Dracaena angustifolia Roxburg Synonym: Pleomele angustifolia (Roxb.) N.E. Br.

Common Name: narrow-leaved dracaena

Tuvaluan Name: launiu

Status: Recent introduction. India to Australia and Melanesia.

Abundance: Occasional to common.

Remarks: Erect shrub with variegated green ribbon-like leaves with white margins. Planted ornamental in houseyard gardens. Leaves, both green and white and green variegated varieties, used in head garlands (fou) and ornamentation.

Recorded: RRT 2003; T, F \& F 2010; RRT 2016

Voucher Photographs: DPTV0900, 2053, 2652, 2653; DSC02550

Dracaena fragrans (L.) Ker-Gawl.

Synonyms: Alectris fragrans L.; Pleomele fragrans (L.) Salisb.

Common Names: dracaena, dragon flower, pleomele

Tuvaluan Name: talasina launiu (Seluka 1997)

Status: Recent introduction. Tropical Africa.

Abundance: Rare. 
Remarks: Planted ornamental and pot plant. Reported present by Seluka (1997), but not seen by the author and may have been mistaken for $D$. angustifolia. Seluka reports that the plant is used for body ornamentation and for embalming corpses (SS 1997).

Recorded: SS 1997

Dracaena sanderiana Sander ex Mast.

Common Names: ribbon dracaena, ribbon plant, lucky bamboo, Belgian evergreen

Tuvaluan Name: talasina kena (Seluka 1997)

Status: Recent introduction. Cameroon.

Abundance: Common.

Remarks: Upright shrub with ribbon-like green or variegated leaves. Planted ornamental and pot plant with green leaves that are used in head garlands (fou) and for mulching

Recorded: SS 1997; RRT 2003; T, F \& F 2010; RRT 2016

Voucher Photographs: DPTV2054, 2087, 2215, 2216, 2870, 2871

\section{Sansevieria trifasciata Prain}

Common Names: bowstring hemp, mother-in-law's tongue

Tuvaluan Name: tapua lau makaikai (Seluka 1997)

Status: Recent introduction. Tropical West Africa.

Abundance: Occasional.

Remarks: Planted ornamental and pot plant at the Vaiaku Lagi Hotel and in a number of other houseyard gardens.

Recorded: RRT 1991; RRT \& WAW 1993; SS 1997; RRT 2003; T, F \& F 2010; RRT 2016

Voucher Photographs: DPTV0653, 3370

\section{Alliaceae (ONiOn FAMily)}

\section{Allium fistulosum L.}

Common Names: green onion, spring onion, Welsh onion, Japanese bunching onion

Tuvaluan Name: aniani (Ff; Tvd)

Status: Recent introduction. East Asia.

Abundance: Uncommon.

Remarks: Planted in home food gardens in 1991and in the Taiwan ICDF Garden in 2010 and 2016. Green leaves used as a spice or garnish in cooking and, according to Seluka, fed to animals. Can be developed as a potentially important spice and health plant for use with raw fish and other foods.

Recorded: RRT 1991; SS 1997; T, F \& F 2010; RRT 2016

Voucher Photographs: DPTV2326, 2332, 2375; DSC02660

\section{Allium sativum L.}

Common Name: garlic

Status: Recent introduction. South Asia.

Abundance: Rare.

Remarks: One plant, reportedly planted from imported garlic cloves, seen in home garden by the Matron of the Hospital in 1991.

Recorded: RRT 1991

Voucher Photographs: DPTV2378

\section{Allium schoenoprasum L.}

Common Name: chives

Status: Recent introduction. Northern hemisphere.

Abundance: Uncommon. 
Remarks: Pot herb cultivated in houseyard garden in north Fogafale Islet in 2010 and in the Taiwan ICDF Garden in 2016. Tender green leaves used raw as a spice in cooking.

Recorded: T, F \& F 2010; RRT 2016

Voucher Photographs: DPTV2261; DSC02661

Allium tuberosum Rottler ex. Sprengle

Common Name: Chinese chives

Status: Recent introduction. East Asia.

Abundance: Uncommon.

Remarks: Herb cultivated in the Taiwan ICDF Garden in 2010 and 2016.

Recorded: T, F \& F 2010; RRT 2016

Voucher Photographs: DPTV2379; DSC02619

\section{AMARYLLIDACEAE (AMARYLLIS LILY FAMILY)}

\section{Crinum asiaticum L.}

Common Names: false spider lily, crinum lily, grand crinum

Tuvaluan Names: tapua (Ff; TvD); talotalo (Nm, Nt; Tvd)

Status: Recent introduction. Tropical Asia.

Abundance: Abundant.

Remarks: Planted ornamental, often along borders. Occasionally adventive along borders of excavated taro gardens (pela) and wasteplaces. Reported present as early as 1898 by Maiden (1904). Flowers used in head garlands (fou) and white inner stems sometimes used in garlands. Maiden (1904) reports that Mrs. David said: "The trader said he introduced this plant from Samoa. Its flowers are very much valued by youths and maidens, who bind the long narrow white perianth segments into wreaths.” Koch (2004) reports that women on Niutao skim off boiled coconut oil with a folded leaf; and that the leaves are used medicinally along with coconut oil to cover burns and the lower part of the stems squeezed with water and rubbed on the skin to treat rheumatism, and elsewhere in Tuvalu to treat eye disease and as a meat tenderizer.

Recorded: JHM 1904; RRT 1991; RRT \& WAW 1993; SS 1997; RRT 2003; T, F \& F 2010; RRT 2016

Voucher Photographs: DPTV0693, 0868, 0937, 2101, 2133, 2284, 3386, 3393, 3394, 3456, 3488, 3489a, 3781

Crinum augustum Roxb.

Common Names: crinum lily, Queen Emma lily

Tuvaluan Names: tapua (Ff; Tvd); talotalo (Nm; Tvd)

Status: Recent introduction. Mauritius and Seychelles.

Abundance: Uncommon.

Remarks: Planted ornamental with reddish stems and flowers. Leaves, flowers and white stems used in garlands.

Recorded: RRT 2003; T, F \& F 2010

Voucher Photographs: DPTV0867, 0937, 2082, 2083, 1138, 3557

Crinum xanthophyllum Hannibal

Common Name: yellow crinum lily

Tuvaluan Names: tapua palagi (Ff); talotalo palagi (Nm)

Status: Recent introduction. Fiji, New Caledonia.

Abundance: Occasional.

Remarks: Planted ornamental lily with yellow-green to bright yellow mature leaves. Sometimes mistaken for a C. asiaticum cultivar, which is larger and has green, rather than yellow, mature leaves. Leaves, flowers and white stems occasionally used in leis and garlands; yellow leaves often used to make a Cook Island style head garlands (fou). 
Recorded: RRT 2003; T, F \& F 2010; RRT 2016

Voucher Photographs: DPTV0869, 2530, 3531, 3532a

Crinum zeylanicum L.

Common Name: milk-and-wine lily

Tuvaluan Names: tapua (Ff; Tvd); talotalo (Nm; Tvd)

Status: Recent introduction. Southern Africa to tropical Asia.

Abundance: Uncommon.

Remarks: Planted ornamental with reddish stems and white flowers with central reddish stipes. Planted in the Vaiku Lagi Hotel garden.

Recorded: RRT 2003; T, F \& F 2010

Voucher Photographs: DPTV2044

Hippeastrum puniceum (Lam.) Urban

Synonyms: H. equestre (Ait.) Herb.; Amaryllis equestris Ait.

Common Names: Barbados lily, amaryllis

Tuvaluan Names: lili (Ff, Nm; Tvd)

Status: Recent introduction. Tropical America.

Abundance: Common.

Remarks: Planted ornamental lily with salmon-orange colored flowers in houseyard and other ornamental gardens. Flower worn over ear or in hair by women as sei and used in garlands. Possibly mistaken for Hippeastrum reginae by Seluka (1997).

Recorded: RRT 1991; RRT \& WAW 1993 (24180); SS 1997; RRT 2003; T, F \& F 2010; RRT 2016

Voucher Photographs: DPTV2091, 0872, 2231, 2277, 2947, 3518, 3549

Hymenocallis pedalis (Jacq.) Herbert

Synonyms: Often misidentified as Hymenocallis littoralis (Jacq.) Salisb. ; Pancratium littorale Jacq.

Common Name: spider lily

Tuvaluan Name: lili (Ff, Nm; Tvd)

Status: Recent introduction. Tropical America.

Abundance: Uncommon.

Remarks: Planted ornamental in new Government Building in 2010 garden and seen previously in some houseyard gardens. Flowers and leaves used in garlands; attractive dangling flowers popular for wearing over the ear or in the hair as a sei.

Recorded: RRT 1991; RRT \& WAW 1993; RRT 2003; T, F \& F 2010; RRT 2016

Voucher Photographs: DPTV2497; DSC02969

Proiphys amboinensis (L.) Herbert

Synonyms: Eurycles amboinensis (L.) Lind.; E. sylvestris Salisb.

Common Names: Amazon lily, Brisbane lily, Cardwell lily

Status: Recent introduction. Malaysia and northern Australia.

Abundance: Rare.

Remarks: Planted ornamental in household garden. Not seen since 2003.

Recorded: RRT 2003

Zephyranthes rosea (Lindl.) Green

Common Names: pink lady, pink star of Bethlehem, pink zephyr flower, rain lily

Tuvaluan Name: sūsana (Ff, Nm; Tvd)

Status: Recent introduction. Guatemala and the West Indies.

Abundance: Common.

Remarks: Small grass-like lily with pink or rose-colored flowers. Planted ornamental, often as a border, and apparently naturalized in some houseyard gardens and ruderal sites. Flowers used in head garlands (fou), 
worn over the ear or in the hair as (sei) and for house decoration, often threaded on a coconut leaflet midrib (tua niu).

Recorded: RRT 1991; RRT \& WAW 1993; SS 1997; RRT 2003; T, F \& F 2010; RRT 2016

Voucher Photographs: DPTV570b, 0572, 2030, 2085, 2162, 2163, 2832, 3528, 3666

\section{ARACEAE (ARUM OR TARo FAMILY)}

Aglaonema commutatum Schott

Common Names: Chinese evergreen, aglaonema

Status: Recent introduction. Indonesia to the Pacific Islands.

Abundance: Uncommon.

Remarks: Ornamental potplant in houseyard gardens.

Recorded: RRT 2003; T, F \& F 2010; RRT 2016

Voucher Photographs: DPTV1180a, 2494

Alocasia macrorrhizos (L.) G. Don

Synonyms: Alocasia macrorrhiza (L.) Schott; A. indica (Roxb.) Schott

Common Names: giant taro, elephant ears

Tuvaluan Names: tāmū (Ff; TvD); kape (Nm, Nt)

Status: Aboriginal or recent introduction? Tropical Asia, but an aboriginal introduction throughout most of Polynesia.

Abundance: Occasional.

Remarks: Found naturalized around giant swamp taro pits, other garden areas and under neglected coconut plantations. Occasional as a planted ornamental and pot plant, but rarely planted as a food plant today. Imported varieties from Samoa and Tonga planted at PRAP experimental nursery in the late 1990s and early 2000s. Lower stem is cooked, but only as an emergency staple. The leaves, which cause skin irritation, are not edible. Older leaves used as mulch and fertilizer. An important staple food plant in Samoa and Vava'u in northern Tonga, but seen as an emergency staple in many areas of the Pacific (Whistler 2009).

Recorded: RRT 1991; RRT \& WAW 1993; SS 1997; RRT 2003; T, F \& F 2010; RRT 2016

Voucher Photographs: DPTV0529, 0999, 1167a, 2219, 2731, 2745, 3547

Alocasia sanderiana Bull. x “Amazonica”

Synonym: Alocasia x “Amazonica”

Common Names: alocasia, kris plant

Tuvaluan Name: taliga lasi (Seluka 1997)

Status: Recent introduction. Philippines.

Abundance: Rare.

Remarks: Ornamental pot plant with dark-green variegated leaves with silver-white edges and veins.

Apparently a hybrid cross between A. sanderiana and other species. Reported present by Seluka.

Recorded: SS 1997

Caladium bicolor (Ait.) Vent.

Common Names: artist's pallet, caladium

Tuvaluan Names: talo palagi (Ff; Tvd?); taliga kula (“red ears”; Seluka 1997)

Status: Recent introduction. Brazil.

Abundance: Occasional.

Remarks: Taro-like plant with variegated green, pink and white leaves. Planted ornamental and pot plant.

Seluka reports that the leaves are used as mulch and for embalming corpses.

Recorded: RRT 1991; RRT \& WAW 1993; SS 1997; RRT 2003; T, F \& F 2010; RRT 2016

Voucher Photographs: DPTV090, 2692, 2701, 2730, 2922, 3550 


\section{Colocasia esculenta L.}

Synonyms: Colocasia antiquorem Schott; Caladium esculentum Vent.

Common Names: taro

Tuvaluan Names: talo (Ff, Nm, Nt; TvD)

Status: Aboriginal introduction. Tropical Asia.

Abundance: Occasional to locally common.

Remarks: Food plant and an important plant in excavated giant swamp taro (Cyrtosperma) pits (pela). Also seen the Agricultural Department nursery and in sustainable agriculture for climate change plots in 2016. A major staple food crop in higher islands, but less important in Tuvalu. Starchy corms cooked as a staple food and young leaves cooked as a green vegetable or spinach. Also fed to animals and leaves used in mulching. Names of taro varieties listed in the Tuvaluan dictionary include talo falani, talo kena, talo kula. talo Manua and talo palagi, the final of which is the Samoan name for Xanthosoma, taro. This, plus the name talo Manua, meaning taro from Manu'a, an island in American Samoa, possibly indicates that this taro cultivar was either an aboriginal or more recent introduction into Tuvalu from Samoa, which supports Maiden's information that talo was a later introduction which replaced ti (Cordyline fruticosa) as a supplementary staple food crop. New hybrid cultivars planted in the Agricultural Deartment nursery, the Taiwan garden and in the Global Climate Change Alliance gardens in north and south Fogafale Islet.

Recorded: JHM 1904; RRT 1991; RRT \& WAW 1993; SS 1997; RRT 2003; T, F \& F 2010; RRT 2016

Voucher Photographs: DPTV0936, 2185, 2186, 2262, 2853, 3326, 3327, 3375b, 3378b, 3389b, 3390, 3391, 3408, 3411, 3434, 3438b, 3439b, 3440, 3441, 3442b, 3443b, 3444, 3445, 3446, 3447b, 3448b, 3462, 3463, 3464, 3465, 3685a, 3686a, 3730, 3731, 3732, 3734b, 3735b, 3737; DSC02582

Cyrtosperma chamissonis (Schott) Merr.

Synonyms: Cyrtosperma edule Schott; C. merkusii (Hask.) Schott

Common Names: giant swamp taro

Tuvaluan Names: pulaka (Ff, Nm; TvD)

Status: Aboriginal introduction. New Guinea and western Pacific Islands, to Micronesia and Polynesia. Abundance: Occasional.

Remarks: Planted in excavated taro pits (pela) near the air terminal on Fogafale Islet and uncommon elsewhere on Fogafale, but more common on some of the other atolls, such as on Niutao where Koch (2002) reported pits up to $400 \mathrm{~m}$ long by $40 \mathrm{~m}$ wide. Also planted in the Agricultural Deartment nursery, the Taiwan garden and in the Global Climate Change Alliance gardens in north and south Fogafale Islet. A very important staple root crop and ceremonial food in the past, but now consumed less frequently and primarily reserved for special occasions. A number of cultivars are recognized including pulaka kula, ikalaoi, paipaitaliga and ika maua, some of which are derived from the Kiribati names. Koch (2002) reports that there are nine cultivars known on Niutao, some of which were introduced from Kiribati. The planting of pulaka is very labor intensive requiring excavation down to the coral base rock and planting in mud enriched with compost or mulch (kaiao). The peeled roots (corms) are cooked in earthen ovens, roasted or boiled. During the early stage of growth, small corms were harvested in the past for everyday use, whereas the larger older corms were used as ceremonial presentations to chiefs or traditional craftsmen or master fishers. Koch (2002) also reports that the leaves are used as compost and strips of the withered leaves and inner parts of the stem are used by the women of Veli Village on Niutao to make special skirts (titifao). Leaves are also used to wrap food and, according to Seluka, the plant is used as an insect repellent.

Recorded: JHM 1904; RRT 1991; RRT \& WAW 1993; SS 1997; RRT 2003; T, F \& F 2010; RRT 2016

Voucher Photographs: DPTV0532, 0686, 0694, 0696, 0723, 2172, 2173, 2174, 2175, 2179, 3374a, 3375a, 3376, 3389a, 3398, 3399, 3401, 3402, 3403, 3404, 3405, 3406, 3407, 3410, 3412, 3414, 3417, 3422a, 3423a, 3424a, 3425a, 3426, 3427, 3428, 3429, 3430, 3435, 3438a, 3439a, 3442a, 3443a, 3447a, 3448a, 3449, 3682, 3683, 3684, 3685b, 3686b, 3687, 3688, 3689, 3690, 3734a, 3735a, 3738, 3739, 3740, 3741, 3742; DSC02568 
Dieffenbachia maculata (Lodd.) Bunt.

Synonym: D. picta Schott

Common Name: spotted dumb cane

Status: Recent introduction. Brazil.

Abundance: Occasional.

Remarks: Ornamental potted plant in household gardens. There is confusion over the taxonomy of the genus Dieffenbachia with D. maculata sometimes being included in D. seguine (Jacq.) Schott. If there two species, then they are probably both present in Tuvalu.

Recorded: RRT 1991; RRT 2003; T, F \& F 2010; RRT 2016

Voucher Photographs: DPTV1011, 2145, 2695, 2766, 2812

Epipremnum pinnatum (L.) Engler

Synonyms: Epipremnum aureum (Lind. ex Andre) Bunt. ; Rhaphidophora aurea (Lind. ex Andre) Birds.; Scindapsus aureus (Lind. ex Andre) Engl.; Pothos aureus Lind. ex Andre; Epipremnum pinnatum cv. Aureum

Common Names: taro vine, pothos, pothos aureus

Tuvaluan Names: tuuteu, tūteu (Seluka 1997)

Status: Recent introduction. Solomon Islands.

Abundance: Occasional.

Remarks: Planted ornamental high climbing vine and pot plant with variegated green and yellow-white leaves in houseyard gardens.

Recorded: RRT 1991; RRT \& WAW 1993; SS 1997; RRT 2003; T, F \& F 2010; RRT 2016

Voucher Photographs: DPTV05013, 0516, 2038, 2247, 2275, 2276

Philodendron sp.

Common Name: philodendron

Status: Recent introduction. Tropical America.

Abundance: Rare.

Remarks: Ornamental pot plant.

Recorded: RRT 1991

Philodendron scandens C. Koch \& Sellow ssp. oxicardium (Schott) Bunt.

Synonym: P. oxycardium Schott

Common Name: philodendron

Status: Recent introduction. Tropical America.

Abundance: Rare.

Remarks: Ornamental pot plant.

Recorded: RRT 1991

Spathiphyllum cv. Clevelandii

Common Names: spathiphyllum, white sails

Status: Recent introduction.

Abundance: Rare or extirpated.

Remarks: Ornamental hybrid pot plant with bright white, sail-like flowers at Government Buildings.

Recorded: RRT 2003

\section{Syngonium podophyllum Schott}

Synonyms: Syngonium angustatum Schott sensu auct.

Common Names: arrowhead vine, syngonium

Status: Recent introduction. Mexico.

Abundance: Occasional.

Remarks: Pot plant and planted ornamental climbing plant with palmlike leaves 
Recorded: RRT 1991; RRT \& WAW 1993; RRT 2003; T, F \& F 2010; RRT 2016

Voucher Photographs: DPTV0681, 0948, 2146, 2272, 2694, 2696

Xanthosoma brasiliense (Desf.) Engler

Common Names: belembe, calalou, Tahitian spinach

Status: Recent introduction. Tropical America.

Abundance: Extirpated.

Remarks: Small taro-like plant in PRAP experimental nursery. Introduced as a potential spinach crop in the early 2000s. Not seen since 2003.

Recorded: RRT 2003

Xanthosoma sagittifolium (L.) Schott

Synonym: Arum sagittifolium L.

Common Names: tannia, yautia, cocoyam, American taro, elephant ears

Tuvaluan Names: talo ni tana (Ff, Nm); talo palagi? (Tvd)

Status: Recent introduction. West Indies.

Abundance: Uncommon.

Remarks: Probably introduced a number of times from both Samoa and Fiji, where it is a widely cultivated.

Staple food crop planted in giant swamp taro (Cyrtosperma) pits at Vaiaku in 1991 and in one houseyard garden in 2010. A similar species, purple (Xanthosoma violaceum) was planted in the PRAP

experimental nursery and one houseyard garden in 2010; also planted in the Tuvalu Agricultural

Department nursery and the EEC-funded Global Climate Change Alliance food garden plots in 2016.

The edible tubers are cooked as a staple food and the young leaves cooked as spinach.

Recorded: RRT 1991; RRT 2003; T, F \& F 2010; RRT 2016

Voucher Photographs: DPTV2886, 3535, 3536, 3537

Xanthosoma violaceum Schott

Common Name: purple cocoyam

Tuvaluan Name: talo ni tana (Ff, Nm)

Status: Recent introduction. Tropical America.

Abundance: Rare to uncommon.

Remarks: Planted in PRAP experimental nursery and one houseyard garden in 2010 and planted in the

Tuvalu Agricultural Department nursery in 2016.

Recorded: RRT 2003; T, F \& F 2010; RRT 2016

Voucher Photographs: DPTV2644, 2645; DSC02591

\section{Arecaceae or Palmae (Palm Family)}

Chrysalidocarpus lutescens $\mathrm{H}$. Wendl.

Synonyms: Dypsis lutescens (H. Wend.) Beentje \& Dransfield

Common Names: golden cane palm, golden-fruited palm

Tuvaluan Name: paama sama (Seluka 1997)

Status: Recent introduction. Madagascar.

Abundance: Uncommon.

Remarks: Ornamental bunching palm. A number of trees planted near the entrance of the new Tuvalu Government Building in 2010 and matured by 2016.

Recorded: SS 1997; T, F \& F 2010; RRT 2016

Voucher Photographs: DPTV2504, 2505, 2506, 3719, 3724

Cocos nucifera L.

Common Name: coconut palm

Tuvaluan Name: niu (Ff, Nm, Nt, Nu; TvD) 
Status: Aboriginal introduction. South Asia and Indian Ocean Islands.

Abundance: Very abundant.

Remarks: Abundant in coastal strand vegetation, in houseyard gardens, and as a roadside tree and very abundant in coconut plantations in rural Fogafale and on uninhabited islets of Funafuti. Found on all Tuvalu's atolls. The Tuvaluan "tree of life" is a major multipurpose crop and wild tree with countless uses. Its endosperm or fat-rich meat of mature nuts is an important staple food, livestock feed, and used to make coconut oil (sinu); the young "green" nuts provide a very important nutrient-rich juice and a very important source of "water"; the sap from the flower spathe is tapped to provide nutritious fresh and sour or fermented toddy (kaleve and kaleve vī ); the fiber or coir from husk of the mature nut is made into cordage (kafa) or twine used in house construction, to tie canoe parts together, make handicrafts and for a range of other purposes; the shell of the nut is used for cups and containers; the timber is used as house posts, for fencing and other purposes; the immature and mature leaves are used to make thatch, mats, baskets, fans, hats, dancing skirts and many other items, and as garden mulch; the very young tender white leaves (kau moe) are used to make head garlands (fou), neck garlands (ula), waist garlands (titi) and body or house decoration (napenape), and the mid-ribs or pinnules of the leaflets are used to make brooms and for a range of other purposes; the gauze-like fiber from the base of the fronds (kaka) is used to strain liquids; most parts are used medicinally; and the shells, wood, dried fronds and other parts constitute the most important fuel for cooking and other purposes. The plant, its leaves and its products also still have important ritual or spiritual importance in Tuvalu. There are a number of recognized varieties including, niu kafa that produces good fiber for making string and rope (kafa), niukafatea, fuausi, niukita, which produces big bunches of nuts, niu utogau that produces nuts with husks than can be chewed like sugarcane for their sweet juice (Jackson 2001), and niu Fiti, refereeing to an orange variety introduced from Fiji.

Recorded: CH 1896; JHM 1904; RRT 1991; RRT \& WAW 1993; SS 1997; RRT 2003; T, F \& F 2010; RRT 2016

Voucher Photographs: DPTV0547, 0548, 0556, ,0557a, , 0574, 0576, 0579, 0591d, 0591d, 0650, 0736, 0749, 0758, 0760, 0767, 0771b, 0779, 0787b, 0799, 0807, 0809, 0812, 0813, 0814, 0844, 0845, 0864, 0865, 0971, 0972, 0990, 0991, 0992, 0995, 1036, 1040, 1041, 1045, 1050, 1056, 1083, 1084, 1085a, 1088, 1089, 1092, 1107a, 1171, 2282, 2492, 2658, 2793, 2794, 2795, 2799, 2805, 2896, 2954, 2955, 2984, 2993, 2994, 3007, 3031, 3040c, 3041c, 3042d, 3052b, 3053, 3067b, 3073a, 3077c, 3079c, 3180, 3187, 3200, 3202, 3251, 3252, 3255, 3256, 3257, 3258, 3259, 3261, 3262, 3288, 3302c, 3302c, 3311c, 3312c, 3313c, 3314c, 3315c, 3316c, 3317c, 3325a, 3344, 3345, 3346, 3347, 3348, 3349, 3422b, 3423b, 3424b, 3425b, 3591, 3592, 3595, 3596, 3598, 3599, 3604, 3605, 3606, 3611c, 3628, 3720a, 3757, 3784

Pritchardia pacifica Seem. \& Wendl.

Synonym: Eupritchardia pacifica (Seem. \& Wendl.) O. Ktze.

Common Names: Pacific fan palm, Fiji fan palm

Tuvaluan Name: niu piu (Ff, Nm; Tvd)

Status: Recent introduction. Fiji, Tonga, and Samoa.

Abundance: Rare.

Remarks: Planted ornamental. Two mature fruiting palms planted in front of Tuvalu Government Building and matured in 2016. Reportedly planted in colonial times and much more common in the past. Fanlike leaves used for decoration and small fruit eaten by children, Small edible fruit consumed in Fiji, Tonga and elsewhere in the Pacific.

Recorded: T, F \& F 2010; RRT 2016

Voucher Photographs: DPTV3712, 3716, 3717, 3719, 3725, 3726b

Ptychosperma macarthuri (Wendl.) Nicholson

Common Names: MacArthur palm, hurricane palm

Status: Recent introduction. Cape York Peninsula, Australia to New Guinea.

Abundance: Rare. 
Remarks: A number of trees were planted in the landscaping near the entrance of Tuvalu Government Building in 2010 and had matured by 2016.

Recorded: T, F \& F 2010; RRT 2016

Voucher Photographs: DPTV2522, 2523, 2524

\section{BROMELIACEAE (PINEAPPLE FAMILY)}

Ananas comosus (L.) Merrill

Common Name: pineapple

Tuvaluan Names: fala, painapolo (Ff, Nm; TvD)

Status: Recent introduction. Brazil.

Abundance: Uncommon.

Remarks: Food plant in containers in houseyard gardens, in some cases planted from crowns of imported pineapples. Not seen in 2016.

Recorded: RRT 1991; RRT \& WAW 1993; SS 1997; RRT 2003; T, F \& F 2010

Voucher Photographs: DPTV1033, 1156, 2193, 2865

\section{CANNACEAE (CANNA FAMILY)}

\section{Canna indica L.}

Common Names: Indian shot, canna

Status: Recent introduction. West Indies.

Abundance: Rare.

Remarks: Planted ornamental with red flowers at the Blue Ocean Bar in south Fogafale.

Recorded: T, F \& F 2010

Voucher Photographs: DPTV2919, 2920, 2921, 3581

Canna x generalis L.H. Bailey

Common Names: canna, canna lily

Status: Recent introduction. West Indies.

Abundance: Rare.

Remarks: Planted ornamental hybrid.

Recorded: RRT 1991; RRT \& WAW 1993; RRT 2003

Voucher Photograph: DPTV0904

\section{COMMELINACEAE (DAYFLOWER OR SPIDERWORT FAMILY)}

Callisia fragrans (Lindl.) Woodson

Synonyms: Spironema fragans Lindl.; Rectanthera fragrans (Lindl.) Degener

Common Names: fragrant inch plant, basketplant

Status: Recent introduction. Tropical America.

Abundance: Rare.

Remarks: Single plant seen in waste place on the lagoon side of Tuvalu Government Building in 2010, possibly introduced from Fiji as part of the landscaping.

Recorded: T, F \& F 2010

Voucher Photographs: DPTV2070

Commelina diffusa Burm $\mathrm{f}$.

Synonym: Commelina pacifica Vahl.

Common Names: commelina, dayflower

Tuvaluan Names: mouku solo (Ff); mouku tolo (Nm) 
Status: Recent introduction. Tropical Asia, extending into the Pacific Islands where it is considered to be either native or an aboriginal introduction in Fiji and Tahiti. Possibly an aboriginal introduction, but probably a recent introduction into Tuvalu and most island groups in the eastern Pacific.

Abundance: Uncommon.

Remarks: Weed in excavated giant swamp taro (Cyrtosperma) pits at Vaiaku.

Recorded: RRT 1991; RRT \& WAW 1993; RRT 2003; T, F \& F 2010; RRT 2016

Voucher Photographs: DPTV0687, 0692, 3395, 3736, 3744

Tradescantia pallida (Rose) D. Hunt

Synonym: Setcreasia purpurea B. K. Boom

Common Names: purple tradescantia, purple heart

Tuvaluan Name: fatu piniki ("pink heart”; Seluka 1997)

Status: Recent introduction. Mexico.

Abundance: Occasional.

Remarks: Ornamental pot plant with dark purple leaves seen near the police station in 2003 and in houseyard gardens in 2010 and 2016.

Recorded: RRT 1991; SS 1997; RRT \& WAW 1993; RRT 2003; T, F \& F 2010; RRT 2016

Voucher Photographs: DPTV0648, 0655, 2458, 2765, 2862b, 3368, 3521, 3522, 3532b, 3533, 3534, 3539a

\section{Tradescantia spathacea Swartz}

Synonyms: Rhoeo spathacea (Sw.) Stearn; Rhoeo discolor (L'Her.) Hance.

Common Names: tradescantia, oyster plant, Moses-in-a-boat

Status: Recent introduction. Mexico and West Indies.

Abundance: Occasional.

Remarks: Pot plant and planted ornamental.

Recorded: RRT 1991; RRT \& WAW 1993; SS 1997; RRT 2003; T, F \& F 2010; RRT 2016

Voucher Photographs: DPTV0965, 2724, 2732, 2733, 2862a

Tradescantia zebrina Bosse

Synonyms: Zebrina pendula Schnizl.

Common Names: wandering Jew, silver inch plant

Status: Recent introduction. Mexico.

Abundance: Rare.

Remarks: Ornamental pot plant at Hospital Matron's garden at Vaiakufou.

Recorded: RRT 1991; RRT \& WAW 1993; RRT 2003

\section{CYPERACEAE (SEDGE FAMILY)}

\section{Cyperus compressus L.}

Common Names: compressed sedge, summer sedge

Tuvaluan Name: mouku (general term for grasses and weeds)

Status: Recent introduction? Pantropical.

Abundance: Common.

Remarks: Weed growing in rather dense populations in low ground near abandoned taro pits and poorlydrained areas near mangroves and along roadsides and in ruderal sites on South Fogafale Islet. Reported present on Nanumea and Vaitupu by Woodroffe (1991).

Recorded: CDW 1991; RRT 1991; RRT \& WAW 1993; SS 1997; RRT 2003; T, F \& F 2010; RRT 2016

Voucher Photographs: DPTV0636, 2771, 2772, 2890, 3728

Cyperus involucratus Rottb.

Synonym: Cyperus alternifolius L.

Common Names: umbrella sedge, umbrella plant 
Status: Recent introduction. Madagascar.

Abundance: Rare.

Remarks: Reported present on Funāfuti by Maddison (1989) and on Nui by Woodroffe (1985). Not seen in 1991 or subsequently. Planted ornamental in parts of the Pacific that has escaped to invade swamps and mangroves.

Recorded: CDW 1991

Cyperus odoratus L.

Synonym: Torulinium odoratum (L.) S. Hooper

Common Name: fragrant flat sedge

Tuvaluan Name: mouku (general term for grasses and weeds)

Status: Introduced? Pantropical.

Abundance: Rare.

Remarks: Weed of moist roadsides and ruderal sites seen in south Fogafale Islet in 2003. Also reported present by Seluka. Not seen subsequently.

Recorded: SS 1997; RRT 2003

\section{Cyperus rotundus L.}

Common Names: nut sedge, nut grass

Tuvaluan Names: muta (Ff, Nm; TvD)

Status: Recent introduction. Origin uncertain, but now a cosmopolitan weed.

Abundance: Abundant.

Remarks: Weed in flower and vegetable gardens, pot plants, roadsides and other ruderal sites. Tuberous roots used to scent coconut oil. The often unnoticed indigenous beach sedge (Cyperus stoloniferus), which is present in Tonga and Samoa, may also have been present at one time or another in Tuvalu, and probably also known as muta and used for the same purpose.

Recorded: RRT 1991; RRT \& WAW 1993; RRT 2003; T, F \& F 2010; RRT 2016

Voucher Photographs: DPTV2019, 2020, 1160, 1179, 2361

Eleocharis geniculata (L.) Roem. \& Schultes

Common Names: spike sedge, Canada spikerush

Status: Indigenous. Pantropical and subtropical.

Abundance: Uncommon.

Remarks: Reported present on Vaitupu and Nukulaelae by Woodroffe (1991), but not seen or reported from Funafuti.

Fimbristylis cymosa R. Br.

Synonyms: Fimbristylis spathacea Roth; F. pyncnocephala Hillebr.; F. glomerata (Retz.) Nees ex K. Schum. non (Schrad.) Nees; F. atollensis St. John; F. wightiana Nees

Common Name: beach sedge

Tuvaluan Name: mouku milimili taliga (Ff, Nm, Nt)

Status: Indigenous. Pantropical.

Abundance: Common.

Remarks: Found growing in clusters or tufts in open and semi-open places along ocean and lagoon coasts and in disturbed inland sites dominated by limestone rock, sand and debris. Reported from all atolls except Nukufetau. The flowerheads are used as ear cleaners and young girls plait the stems to make impromptu head garlands (fou). Koch (2002) reports that the roots were used on Nui to scent coconut oil and to cast spells to make a person sympathetic or to cause malfortune or death. This use, however, seems to be more characteristic of Cyperus stoloniferus, which could have been present, or Cyperus rotundus (see above).

Recorded: CDW 1991; RRT 1991; RRT \& WAW 1993; SS 1997; RRT 2003; T, F \& F 2010; RRT 2016

Voucher Photographs: DPTV0791, 0820, 0899, 2705, 2863, 3266, 3275; DSC03242 
Fimbristylis dichotoma (L.) Vahl.

Common Name: tall fringe rush

Status: Recent introduction. Pantropical.

Abundance: Uncommon.

Remarks: Found in ruderal sites at the south end of Fogafale Islet in grassy areas bordering the airstrip and in a disturbed site on Tepuka Islet. Reported present on Nui and Nukulaelae by Woodroffe (1991).

Recorded: RRT 2003; T, F \& F 2010; RRT 2016

Voucher Photographs: DPTV0862, 1139, 2532, 2535, 2925, 3793

Kyllinga brevifolia Rottb.

Synonym: Cyperus brevifolius (Rottb.) Hassk.

Common Name: shortleaved spikesedge, green kyllinga

Status: Recent introduction. Old World tropics; now pantropical.

Abundance: Rare.

Remarks: Weed of ruderal sites or found in lawns.

Recorded: RRT 2003

Voucher Photograph: DPTV1152

Kyllinga nemoralis (Forst.) Dandy ex Hutchinson and Dalziel

Synonym: Cyperus kyllinga Endl.

Common Name: white-flowered kyllinga

Tuvaluan Name: mouku (general term for grasses and weeds)

Status: Recent introduction. Paleotropical.

Abundance: Occasional.

Remarks: Weed along roadsides, wasteplaces, lawns and in moist or shady places near dwellings. First reported present in 1993.

Recorded: RRT \& WAW 1993; SS 1997; RRT 2003; T, F \& F 2010; RRT 2016

Voucher Photographs: DPTV0526, 2024, 2071, 2158, 2679, 3418

Mariscus javanicus (Houtt.) Merr.

Synonyms: Cyperus javanicus Houtt; C. canescens Vahl; C. pennatus Lam.; C. stuppeus Forst. f.; $M$. albescens Gaud.; M. pennatus (Lam.) Domin; M. stuppeus (Forst. f.) Merr.

Common Names: sedge, marsh cypress

Tuvaluan Names: mouku filifou (Ff); mouku (Nm); lakau fai tika (Ff?); sika (Seluka 1997)

Status: Indigenous? Paleotropics into the Pacific Islands.

Abundance: Occasional to locally common.

Remarks: Found growing wild in isolated clusters and tufts and in colonies in moist habitats on the coastal strip, on the inner border of coastal strand vegetation, and along borders of the airfield and other ruderal habitats. Also found in excavated Cyrtosperma taro pit areas. Long stems used as small "spears" or javelins in the traditional throwing game tika; stems occasionally used in plaiting head and waist garlands (fou and titi) and to tie up food parcels before cooking.

Recorded: RRT 1991; RRT \& WAW 1993; SS 1997; RRT 2003; T, F \& F 2010; RRT 2016

Voucher Photographs: DPTV0546, 2177, 2178, 2463, 2609, 3379

Pycreus polystachyos (Rottb.) P. Baeuv.

Synonym: Cyperus polystachyos Rottb.

Common Name: sedge

Tuvaluan Name: mouku (general term for grasses and weeds)

Status: Recent introduction. Uncertain origin, now pantropical and subtropical.

Abundance: Occasional.

Remarks: Weed of roadsides, wet places and in grassy areas along the airstrip. 
Recorded: RRT 2003; T, F \& F 2010; RRT 2016

Voucher Photographs: DPTV0625, 1141, 1177, 2573, 2574

\section{DIOSCOREACEAE (YAM FAMILY)}

\section{Dioscorea alata L.}

Common Names: yam, greater yam, winged yam

Tuvaluan Name: ufi (Ff, Nm; TvD)

Status: Recent introduction. Southeast Asia.

Abundance: Uncommon.

Remarks: Single plant growing in a front yard garden. Also planted in PRAP garden in 2003; also seen in 2016, but doing poorly in the EEC-funded Global Climate Change Alliance food garden plots and in plastic bags for distribution from the Tuvalu Agricultural Department Nursery for Utilising Climate Resilient Crops. Apparently planted using tissue culture technology.

Recorded: RRT 2003; RRT 2016

Voucher Photographs: DPTV0888; DSC0257, 03055

\section{Dioscorea nummularia Lam.}

Common Name: thorny yam

Tuvaluan Name: tivoli (Ff)

Status: Recent introduction. Southeast Asia.

Abundance: Occasional.

Remarks: Food plant with thorny stems growing on a trellis in an open houseyard garden in Vaiaku in 2003 and in at least two other gardens in 2010, one climbing high in a breadfruit tree. Almost certainly introduced from Fiji where it its known as tivoli.

Recorded: RRT 2003; T, F \& F 2010

Voucher Photographs: DPTV0508, 0509, 0510, 2937

\section{HeLiConiaceAe (HELICONIA FAMILY)}

Heliconia collinsiana R.F. Griggs

Synonym: Heliconia pendula Wawra

Common Names: hanging heliconia, fish-pole heliconia

Status: Recent introduction. Guatemala.

Abundance: Rare.

Remarks: Planted ornamental in front garden of the Office of the Prime Minister in 2003 and in another houseyard garden north of the hotel in 2010; not seen in 2016.

Recorded: RRT 1991; RRT \& WAW 1993; SS 1997; RRT 2003; T, F \& F 2010

\section{IRIDACEAE (IRIS FAMILY)}

Trimezia martinicensis (Jacq.) Herbert

Common Name: walking iris

Status: Recent introduction. Caribbean.

Abundance: Uncommon.

Remarks: Planted ornamental with yellow flowers at the Hotel and Tuvalu Government Building gardens. Not seen in 2016.

Recorded: T, F \& F 2010

Voucher Photographs: DPTV2092, 2949 


\section{LILIACEAE (LILY FAMILY)}

\section{Asparagus officinalis L.}

Common Name: asparagus

Status: Recent introduction. Southern Europe, North Africa and Western Asia.

Abundance: Rare.

Remarks: Food plant in the Taiwan ICDF Garden in 2010.

Recorded: T, F \& F 2010

Voucher Photographs: PTV2406, 2407

Chlorophytum comosum (Thunb.) Jacq.

Synonyms: Chlorophytum elatum R. Br.; Chlorophytum capense (L.) Voss

Common Names: spider plant, ribbon plant, bracket plant

Status: Recent introduction. Africa.

Abundance: Rare.

Remarks: Ornamental pot plant in Vaiaku Lagi.

Recorded: RRT 2003

\section{Gloriosa superba L.}

Synonym: Gloriosa rothschildiana O’Brien

Common Names: climbing lily, gloriosa lily, glory lily, fire lily

Tuvaluan Names: lakau laupiki (Ff); nareau (Seluka 1997)

Status: Recent introduction. Tropical Africa.

Abundance: Occasional.

Remarks: Planted ornamental and pot plant in houseyard gardens and at Vaiaku Lagi Hotel. Climbing lily with bright orange, orchid-like flowers. Flowers and shiny-green leaves with curled ends plaited in head garlands (fou) and wreaths (pale). According to Seluka the plant is used for embalming corpses.

Recorded: RRT 1991; RRT \& WAW 1993; SS 1997; RRT 2003; T, F \& F 2010; RRT 2016

Voucher Photographs: DPTV0932, 1010, 2051, 2052; DSC02535

\section{MUSACEAE (BANANA FAMILY)}

The nomenclature for the genus Musa is confused, with most of the common seedless cultivars or clones being triploid crosses of the fertile species Musa acuminata Colla and M. balbisiana Colla. The Latin binomials $M$. nana Loureiro, M. sapientum L., and M. paradisiaca L. are commonly used as follows: $M$. nana for the "dwarf Cavendish", and M. sapientum for the taller bananas, which are generally eaten ripe, but which are also cooked throughout the Pacific as starchy staples, and $M$. paradisiaca for the starchier bananas or plantains, which are usually eaten cooked as a staple starch. but occasionally eaten ripe as fruit. The nomenclature most widely used by agronomists is that developed by Simmonds, which classifies all cultivars or clones on the basis of their assumed genetic background, eg. Musa ABB Group would be a triploid cross of one M. acuminata group and two $M$. balbisiana groups. Both nomenclature systems are presented here to more precisely identify the clones that are currently present Tuvalu, all of which are generally referred to as futi.

Musa (AAA Group) Simmonds

Synonyms: M. sapientum L.; M. paradisiaca L. var. sapientum (L.) Kuntze; M. paradisiaca L. ssp. sapientum (L.) Kuntze; M. acuminata Colla cvs

Common Names: Robusta banana, poyo, Mons Marie, Veimama

Tuvaluan Name: fuamaoluga ("high fruiting"; Ff, Nm)

Status: Recent introduction. Southeast Asia.

Abundance: Occasional. 
Remarks: Food plant in houseyard gardens and banana groves and at the Agricultural Department compound. Immature fruit cooked as a staple and ripe fruit eaten as a fruit. Leaves used as trays for food and dried leaves as cigarette wrappers. This was, historically, the main export banana to New Zealand from Samoa, Tonga and Fiji.

Recorded: RRT 1991; RRT \& WAW 1993; RRT 2003; RRT 2016

Musa (AAA Group) Simmonds

Synonyms: M. sapientum L.; M. paradisiaca L. var. sapientum (L.) Kuntze; M. paradisiaca L. ssp. sapientum (L.) Kuntze; M. acuminata Colla cvs

Common Name: dwarf Cavendish banana

Tuvaluan Name: fuamaulalo ("low fruiting"; Ff, Nm)

Status: Recent introduction. Southeast Asia.

Abundance: Occasional.

Remarks: Short banana that bears fruit low to the ground. Planted in some houseyard gardens and garden areas.

Recorded: RRT 1991; RRT \& WAW 1993; RRT 2003; T, F \& F 2010; RRT 2016

Voucher Photograph: DPTV2264

Musa (AB Group) Simmonds

Synonyms: Musa x paradisiaca L. var. hort. Pisang raja (M. acuminata Colla x M. balbisiana Colla)

Common Names: lady's finger banana, pisang rajah (Indonesia)

Tuvaluan Name: tamatama ai lima (Ff); misiluki (Nm); inisi (Ff?)

Status: Recent introduction. South India.

Abundance: Common.

Remarks: Planted in houseyard gardens and in banana groves, often in boxing-in plots with leaf mulching. Immature fruit cooked as a staple and ripe fruit eaten as a fruit. A banana with resistance to most diseases and that seems to grow well in the atoll environment.

Recorded: RRT 1991; RRT \& WAW 1993; RRT 2003; T, F \& F 2010; RRT 2016

Voucher Photographs: DPTV0683, 1175, 2122, 2279, 2818, 3431, 3692

Musa (ABB Group) Simmonds

Synonyms: Musa x paradisiaca L. var. hort. Bluggoe (M. acuminata Colla x M. balbisiana Colla)

Common Names: cooking banana, plantain, bluggoe

Tuvaluan Name: pata (Ff, Nm)

Status: Aboriginal introduction? Southeast Asia and Pacific.

Abundance: Abundant.

Remarks: Banana with thick light-green skin. Important traditional supplementary staple in many areas of the Pacific, where it seems to be an aboriginally introduced cultivar and known as bata or pata in Fiji and Polynesia respectively. The most common banana cultivar on Funafuti. Planted in houseyard gardens, near taro pits and in banana groves. Immature fruit cooked as a staple and ripe fruit eaten as a fruit. Leaves used for mulching and as cigarette wrappers.

Recorded: RRT 1991; RRT \& WAW 1993; RRT 2003; T, F \& F 2010; RRT 2016

Voucher Photographs: DPTV2121, 3490, 3491

Musa (ABB Group) Simmonds

Synonyms: Musa x paradisiaca L. var. hort. "Bluggoe" (M. acuminata Colla x M. balbisiana Colla)

Common Names: cooking banana, ash plantain, blue Java

Tuvaluan Name: kefu (Ff, Nm)

Status: Aboriginal introduction? Southeast Asia and Pacific.

Abundance: Occasional.

Remarks: Banana with thick powdery greenish-blue-gray skin. Important traditional supplementary staple in many areas of the Pacific, where it seems to be an aboriginally introduced cultivar and, like pata, above, 
is also known as bata or pata in Fiji and Polynesia respectively. Planted in houseyard gardens, near taro pits. Immature fruit cooked as a staple and ripe fruit eaten as a fruit. Also an animal food.

Recorded: RRT 1991; RRT \& WAW 1993; RRT 2003; T, F \& F 2010

Voucher Photograph: DPTV0697

Musa cultivars

Tuvaluan Name: futi (general name for banana)

Status: Recent introduction. Taiwan.

Abundance: Uncommon.

Remarks: Unidentified new banana cultivars introduced from Taiwan seen in both the Agricultural

Department Nursery and the Taiwan farm in 2016.

Recorded: RRT 2016

Voucher Photograph: DSC02581

\section{ORCHIDACEAE (ORCHID FAMILY)}

Papilionanthe "Agnes Joaquim"

Synonym: Vanda "Agnes Joaquim"

Common Name: Agnes Joaquim vanda orchid

Status: Recent introduction.

Abundance: Uncommon.

Remarks: Orchid planted in two houseyard gardens and at the Prime Minister's and Governor General's residences.

Recorded: RRT 2003; T, F \&F 2010

Voucher Photographs: DPTV1008, 2049, 3551

Vanilla planifolia Jacks. Ex Andrews

Synonym: Vanilla fragrans Ames

Common Names: vanilla, flat-leaved vanilla

Tuvaluan Name: vanila (Ff; TvD)

Status: Recent introduction. Mexico.

Abundance: Extirpated.

Remarks: Plants, introduced by tissue culture at PRAP experimental nursery. Not seen since 2003.

Recorded: SS 1997; RRT 2003

\section{Pandanaceae (Pandanus Family)}

The nomenclature for the genus Pandanus is, like Musa, confused, with some taxonomists classifying many of the common cultivars and wild clones or species, both edible and non-edible, as forms or varieties of $P$. tectorius. Other taxonomists consider them distinct species, often listing numerous species or varieties for a given area. Thus, the identifications here must be considered provisional, with most named cultivars being grouped under $P$. tectorius. Other widespread forms, such as $P$. dubius Spreng., a widespread edible species, and other varieties that are widely cultivated for their leaves for use handcrafts, are also possibly present, but not listed here.

Pandanus tectorius Warb.

Synonym: Pandanus pyriformis Gaud.

Common Names: pandanus, screw pine

Tuvaluan Name: fala, fala vao ("wild pandanus”; Ff, Nm); fala tinakaleve (edible, planted; Ff, Nm); kie (Ff, $\mathrm{Nm}$ ); falaketi (edible; Ff); fala kai (edible; Nm); teou, te to (Nui; Woodroffe 1991)

Status: Indigenous and, in the case of some cultivars, probably aboriginal or recent introductions from other Pacific Islands. Pacific Islands and found throughout most of Melanesia, Polynesia and Micronesia. 
Abundance: Abundant.

Remarks: Common in coastal strand and lagoon vegetation on the main inhabited islets and uninhabited atoll islets, in rural agricultural areas, around taro pits and in houseyard gardens. One of the most dominant species on the eastern coral rubble rampart of east Fogafale Islet. Found on all atolls in Tuvalu. There are both wild varieties, known as fala vao, and cultivated edible varieties, known as fala kai, that have larger more succulent fruit, and non-edible varieties, the leaves of which are used in handicrafts. There are a number of named cultivars or varieties, some of which are probably rare, extinct or in danger of extinction. Varieties listed in the Tuvlauan dictionary include fala ikatā, fala kai, fala polosene, fala pukumakali, fala saeima, fala tinakaleve, fala tinatina, fala utogau and fala vao, some of which, as suggested above, may just be general terms for wild and cultivated pandanus. Some of the named cultivars such as tinakaleve are reportedly from Kiribati.

In the cases of the edible and handicraft varieties, both are normally planted vegetatively from cuttings because pandanus do not breed true from seed and will often revert to inferior varieties. The wild varieties often propagate naturally from seed or are spread by pigs, rats or birds that disperse the seeds. The timber and prop roots are used in the construction of traditional sleeping houses and other structures; the old leaves are used to make thatch for traditional thatched houses. There are also distinct named varieties, the young and older leaves of which are favored for making fine mats, baskets, hats, fans, balls for use in traditional games and other woven or plaited handicrafts. The ripe red-orange fruit segments or seeds (fuaga fala)(sometimes referred to as "keys") are chewed as a nutritious fruit or cooked and processed for storage and used as animal food; the ripe red-orange fuaga fala of both wild and cultivated varieties are sliced and used in head garlands (fou), necklaces (ula) and waist garlands (titi). The fragrant cream-white petals of the male flower (sigano) are used in garlands (fou) and body ornamentation and both the petals and the pollen are used to scent coconut oil (sinu). Some neck garlands, ula lau kie and ula galegale are made from pandanus leaves. The inner part of the roots of some varieties was eaten in the past, and the roots, bark and other parts are used medicinally.

Recorded: CH 1896; JHM 1904; RRT 1991; RRT \& WAW 1993; SS 1997; RRT 2003; T, F \& F 2010

Voucher Photographs: DPTV0557b, 0558, 0573, 0591c, 0591c, 0725, 0726, 0727, 0763, 0794, 0803, 0823, 0824, 0833, 0834a, 0927a, 0969b, 0973, 1017b, 1018b, 1021b, 1170, 2184, 2221, 2222, 2283, 2634b, 2640a, 2642, 2737, 2738, 2785b, 2792, 2798, 2803, 2950, 2951, 2952, 2953, 2985, 2986b, 2988, 2996, 3052a, 3064, 3073b, 3077b, 3079b, 3090, 3096, 3097, 3188, 3189, 3190, 3263c, 3271, 3272, 3328, 3329, 3532c, 3586b, 3588, 3589b, 3590, 3600, 3602, 3603, 3614, 3626a, 3721, 3745, 3746; DSC03298

\section{PoAceae OR Graminae (Grass FAMiLy)}

Axonopus compressus (Sw.) Beauv.

Common Name: carpet grass

Status: Recent introduction. Tropical America.

Abundance: Occasional.

Remarks: Grass in houseyard gardens at the Taiwan residence in north Fogafale and at the airport and hotel. First seen in 2003; now increasingly widespread.

Recorded: RRT 2003; T, F \& F 2010; RRT 2016

Voucher Photographs: DPTV0639, 2084, DPTV2086, 2268, 2755, 2756, 2763, 3477

Bothriochloa bladhii (Retz.) S.T. Blake

Synonyms: Dichanthium bladhii (Retz.) Clayton; Andropogon bladhii Retz.; Dichanthium intermedium

(R. Br.) De Wit \& Harl.; Andropogon intermedius R. Br.; Bothriochloa intermedia (R. Br.) Camus

Common Names: blue grass, Australian beardgrass

Status: Recent introduction. Tropical Africa through India to China and Australia.

Abundance: Occasional.

Remarks: Grass in open lots, roadsides and ruderal sites and in areas along the airstrip. 
Recorded: T, F \& F 2010; RRT 2016

Voucher Photographs: DPTV2447, 2448, 2536, 2537, 2550, 3756

Brachiaria subquadripara (Trin.) Hitchc.

Synonym: Panicum subquadriparum Trin.

Common Name: green summer grass, two-spiked panic, two-finger grass

Status: Recent introduction. Tropical Asia, now pantropical.

Remarks: Occasional roadside and ruderal grass.

Recorded: RRT \& WAW 1993 (24167); RRT 2003; T, F \& F 2010; RRT 2016

Cenchrus echinatus L.

Common Names: burgrass, sand bur

Tuvaluan Name: mouku talatala (Ff); mouku tapu (Nm); kateketeke (Nui?; Seluka 1997)

Status: Recent introduction. Tropical America.

Abundance: Common to locally abundant.

Remarks: Weedy grass with bur-like fruits that occurs in clusters or tufts in open and ruderal habitats and in sandy areas near the coast and along the airstrip. Also reported from Nanumea, Nui, Vaitupu and

Niulakita. Bothersome grass with burs that stick on clothing and body hair.

Recorded: RRT 1991; RRT \& WAW 1993; SS 1997; RRT 2003; T, F \& F 2010; RRT 2016

Voucher Photographs: DPTV0626, 2104, 2119, 2362, 2363, 2617, 3365

Chloris barbata (L.) Sw.

Synonym: Chloris inflata Link.

Common Names: finger grass, swollen finger grass

Tuvaluan Name: mouku (general term for grasses and small weeds)

Status: Recent introduction. Tropical America.

Abundance: Common.

Remarks: Grass with attractive pinkish-red flowers occurring locally in isolated clusters or tufts in open and ruderal places, particularly along roadsides and in the lawn at New Government Building. Attractive reddish flower clusters occasionally used in head garlands (fou) and placed in flower vases.

Recorded: RRT 1991; RRT \& WAW 1993 (24302, 24315); RRT 2003; T, F \& F 2010; RRT 2016

Voucher Photographs: DPTV0617, 2068, 2503, 2841, 3354, 3355

Cymbopogon citratus (DC. ex Nees) Staph

Common Name: lemongrass

Tuvaluan Name: moegalō $(\mathrm{Nm})$

Status: Recent introduction. East Indies.

Abundance: Rare.

Remarks: Seen in houseyard gardens and reported from Nanumea where is is known by the Samoan name, moengalō. Not seen since 2003.

Recorded: RRT 2003

Cynodon dactylon (L.) Pers.

Common Name: Bermuda grass

Tuvaluan Name: mouku (general term for grass or small weeds; Ff, Nm); mutia (name from Samoa; Ff)

Status: Recent introduction. Old World.

Abundance: Occasional.

Remarks: Found in open places forming mats or sod in some areas.

Recorded: RRT 1991; RRT \& WAW 1993; RRT 2003; T, F \& F 2010; RRT 2016

Voucher Photographs: DPTV2293, 3540? 
Dactyloctenium aegyptium (L.) Beauv.

Common Names: four-finger grass, beach wire grass, crowfoot grass

Tuvaluan Name: mouku (general term for grasses and small weeds)

Status: Recent introduction. Paleotropics.

Abundance: Common.

Remarks: Found along roadsides, in other ruderal sites and along the airfield.

Recorded: RRT \& WAW 1993; RRT 2003; T, F \& F 2010; RRT 2016

Voucher Photographs: DPTV0559, 1027b, 1142, 2067, 2069, 2093, 2774, 2775, 3527

Digitaria ciliaris (Retz.) Koel.

Synonyms: Panicum ciliare Retz; Digitaria adscendens (HBK) Henr.; Syntherisma ciliaris (Retz.) Schrader

Common Names: crab grass, large crab grass

Status: Recent introduction. Tropical Asia.

Abundance: Occasional.

Remarks: Weed in ruderal sites and along the airfield.

Recorded: RRT \& WAW 1993 (24166); RRT 2003; T, F \& F 2010

Voucher Photographs: DPTV0525, 0534, 0949, 1146, 2474, 2477

Digitaria radicosa (J.S. Presl) Miq.

Synonyms: Panicum radicosm J.S. Presl; Digitaria timorensis (Kunth) Balansa

Common Name: trailing crabgrass

Status: Recent introduction. Tropical Asia?

Abundance: Uncommon.

Remarks: Seen in the Taiwan ICDF Garden.

Recorded: T, F \& F 2010

Voucher Photographs: DPTV2328, 3260, 3372

Digitaria setigera Rot

Synonyms: Panicum pruriens Fisch. ex Trin.; Digitaria pruriens (Fisher ex Trin.) Buse (in Burgess' list 1935); D. microbachne (J. S. Presl) Henr.

Common Names: crab grass, slender crab grass

Tuvaluan Name: mouku (general term for grasses and small weeds)

Status: Recent introduction? Southeast Asia to Polynesia.

Abundance: Uncommon.

Remarks: Weed occurring in clusters or tufts in open and ruderal habitats, often near the coast. It is native or perhaps an ancient introduction into much of the Pacific, but could have been a recent introduction to Tuvalu. Presence not reconfirmed since 1993.

Recorded: RRT 1991 (24319); RRT \& WAW 1993

Voucher Photograph: DPTV0629

Echinochloa colona (L.) Link.

Synonyms: Panicum colonum L.; Oplismenus colonum (L.) HBK.

Common Name: jungle rice

Tuvaluan Name: mouku (general term for grasses and small weeds)

Status: Recent introduction. India.

Abundance: Uncommon.

Remarks: Seen in one wet site in a Vaiaku houseyard garden in a moist site and in the Taiwan ICDF Garden in 2010.

Recorded: T, F \& F 2010

Voucher Photographs: DPTV2207, 2507 
Eleusine indica (L.) Gaertn.

Common Names: wiregrass, goosegrass

Tuvaluan Name: mouku (general term for grasses, sedges and small weeds; Ff, Nm); mouku uaea ("wire grass”; Seluka 1997)

Status: Recent introduction. India, but long naturalized in Old World.

Abundance: Abundant.

Remarks: Growing in rather dense concentrations or colonies in gardens, waste places, roadsides, open lots and other ruderal habitats. Reported present from Funafuti in 1898 by Maiden (1904) and from Nanumea, Nui, Vaitupu and Nukulaelae.

Recorded: JHM 1904; RRT 1991; RRT \& WAW 1993; SS 1997; RRT 2003; T, F \& F 2010; RRT 2016

Voucher Photographs: DPTV0634, 1173, 2040, 3373, 3512b

Eragrostis tenella (L.) Beauv. ex Roem. \& Schult.

Synonym: Eragrostis amabilis (L.) Wight \& Arn. ex Hook. \& Arn.

Common Names: lovegrass, Japanese lovegrass

Tuvaluan Name: mouku (general term for grasses, sedges and small weeds; Ff, Nm)

Status: Recent introduction. Old World.

Abundance: Common.

Remarks: Weed occurring in scattered clusters around buildings, paths, roadsides, wasteplaces and other ruderal sites, and in sandy areas near the coast. Reported from Nanumea, Nui, Vaitupu and Nukulaelae. Reported by Maiden (1904) to be growing in great profusion in 1898 on Funafuti near the ruins of the house of Williams, a trader.

Recorded: JHM 1904; RRT 1991; RRT \& WAW 1993; SS 1997; RRT 2003; T, F \& F 2010; RRT 2016

Voucher Photographs: DPTV0632, 1021a, 2036, 2077, 2126, 2134, 2340, 2673, 3512a, 3652, 3653

Ischaemum murinum G. Forst.

Common Name: ribbed muraina grass

Tuvaluan Name: mouku (general term for grasses, sedges and small weeds; Ff, Nm)

Status: Indigenous. Reported from Tonga, Samoa and Niue.

Abundance: Extirpated?

Remarks: Uncommon littoral grass reported present, with no location, by Seluka (1997). Not seen by current authors and not reported present in Tuvalu by Woodroffe (1991).

Lepturopetium kuniense Morat.

Synonym: Lepturopetium marshallense Fosb. \& Sachet

Status: Indigenous. Reported from New Caledonia.

Remarks: Uncommon grass found along the airfield in 1993. Also reported present from Eniwetak in the Marshall Islands.

Recorded: RRT \& WAW 1993 (24151)

Lepturus repens (Forst. f.) R. Br.

Synonyms: Rottboellia repens Forst. f.; Monoerma repens (Forst. f.) Beauv.

Common Names: bunchgrass, beach bunchgrass

Tuvaluan Name: mouku (general term for grasses, sedges and small weeds; Ff, Nm); mouku lauliliki te titi o Kulu (Nt; Koch 2002); mutia (Seluka 1997)

Status: Indigenous. Pacific Islands.

Abundance: Abundant.

Remarks: Occurring in clusters among strand vegetation on both ocean and lagoon shores and in other sandy habitats. Occasionally found inland in open sites in coconut plantations, woodland and scrub. Reported from all atolls except Nanumaga and Nukufetau. According to Koch (2002), on Niutao, the grass once served as the skirt for the goddess Kulu and was used as a head garland and for love spells and squeezed as a medicine for tuberculosis and urinary problems. Maiden (1904) reports the presence of 
Lepturus acutiglumis Steud. on Funafuti in 1898, although Fosberg et al. (1987) consider this to be only a variety, Lepturus repens var. repens.

Recorded: JHM 1904; RRT 1991; RRT \& WAW 1993 (24320); SS 1997; RRT 2003; T, F \& F 2010; RRT 2016

Voucher Photographs: DPTV 1087, 2095, 2096, 2604, 2607, 2788a, 2807, 3028, 3051, 3091, 3098, 3103, 3104, 3191, 3192

\section{Paspalum setaceum Michx.}

Common Names: thin paspalum, sand paspalum

Status: Recent introduction. Mexico and the southeastern United States.

Abundance: Uncommon.

Remarks: Weed in lawns and disturbed sites, seen in the lawn of the new Tuvalu Government Building.

Recorded: T, F \& F 2010

Voucher Photographs: DPTV2601, 3364, 3713

\section{Paspalum vaginatum Sw.}

Synonyms: Paspalum distichum L. (some authors); P. littorale R. Br.

Common Names: knot grass, salt grass, knotweed, swamp couch grass

Tuvaluan Name: mouku (general term for grasses, sedges and small weeds; Ff, Nm)

Status: Indigenous. Tropical America, but now pantropical.

Abundance: Locally abundant.

Remarks: Grass forming dense patches near beaches, in areas near the mangroves and brackish marshy areas bordering the borrow pits. Also reported from Nui and Vaitupu by Woodroffe (1991).

Recorded: RRT 1991; RRT \& WAW 1993 (24165); RRT 2003; T, F \& F 2010; RRT 2016

Voucher Photographs: DPTV0912, 2032, 2033, 2226, 2227, 2392, 2603

\section{Saccharum officinarum L.}

Common Name: sugar cane

Tuvaluan Name: tolo (Ff; TvD); kaleve, kaleve gau (Nm; TvD)

Status: Recent or, possibly, an aboriginal introduction at some time to Tuvalu. New Guinea and Tropical Asia, but an aboriginal introduction into the Pacific as far east as Hawai'i.

Abundance: Occasional.

Remarks: Planted in houseyard gardens and in excavated Cyrtosperma taro pits (pela) areas. Stems chewed as a snack food and source of juice. A common supplementary food crop and snack food throughout the Pacific Islands.

Recorded: RRT 1991; RRT \& WAW 1993; SS 1997; RRT 2003; T, F \& F 2010; RRT 2016

Voucher Photographs: DPTV2720, 2817

Schizostachym glaucifolium (Rupr.) Munro

Common Names: Polynesian bamboo, Pacific bamboo

Tuvaluan Name: kofe (Nm); tikopia, pamipu (Ff)

Status: Probably native to Melanesia, possibly Fiji, although apparently an aboriginal introduction to all the large island archipelagos as far east as Hawai'i (Whistler 2009). Probably a more recent introduction into Tuvalu.

Abundance: Rare.

Remarks: One small stand seen in Vaiaku in 1991. Vaitupu is reportedly the only island where kofe bamboo still grows. Used for fishing poles, known as kofe, for catching small fishes, such as gatala (Epinephelus spp.), afulu (Mulloidichthys and Parupeneus spp.) and tanutanu (Lethrinus spp.). Kofe is probably the Proto-Polynesian name for this bamboo species.

Recorded: RRT 1991 
Sporobolus fertilis (Steud.) Clayton

Synonyms: Agrostis fertilis Steud.; S. elongatus sensu auct. non R.Br. = diander

Common Name: rat-tail dropseed

Tuvaluan Name: mouku (general term for grasses, sedges and small weeds; Ff, Nm)

Status: Recent introduction. Malaya and Australia to Polynesia and Micronesia.

Abundance: Occasional.

Remarks: Found on roadsides, in waste places and ruderal sites and increasingly common along the road near the airstrip. Often confused with Sporobolus diander (Retz.) P. Beauv. Reported present on Funafuti, Niutao, Nui and Vaitupu in the mid-1980s by Woodroffe (1991).

Recorded: CDW 1991; RRT \& WAW 1993 (24313); RRT 2003; T, F \& F 2010; RRT 2016

Voucher Photographs: DPTV0646, 2041, 3352, 3497, 3498, 3667, 3753

Stenotaphrum micranthum (Desv.) Hubb.

Synonyms: Ophiurinella micrantha Desv.; Stenotaphrum subulatum Trin.

Tuvaluan Name: mouku (general term for grasses, sedges and small weeds; Ff, Nm); mouku lauliliki te titi o Kulu (Nt; Koch 2002)

Status: Indigenous. Mascarene Islands in the Indian Ocean through Malesia to eastern Polynesia and the Marshall Islands in Micronesia.

Abundance: Occasional to common.

Remarks: Seen in open but protected sites in coconut plantations and sites inland from the coast. Present on the wave-cut terrace and just inland from the coast on southwest Tepuka Islet. Reported present on Funafuti by Woodroffe in the 1980s and on Nui in the 1960s by Koch (2002) who reports it has the same name and essentially the same uses and beliefs associated with the similar-looking Lepturus repens.

Recorded: CDW 1991; RRT \& WAW 1993 (24313), RRT 2003; T, F \& F 2010; RRT 2016

Voucher Photographs: DPTV0797, 0846, 2782, 2783, 2995, 3201, 3206, 3207, 3208, 3247

Thuarea involuta (Forst. f.) R. Br. ex R. \& S.

Common Names: tropical beachgrass, Kuroiwa grass, thuarea

Tuvaluan Names: mouku solo (Ff); mouku tolo (Nm); mouku fau (Seluka 1997)

Status: Indigenous. Madagascar to Eastern Polynesia and Micronesia.

Abundance: Common.

Remarks: Creeping grass found in strand vegetation and sandy areas on both ocean and lagoon coasts in large concentrations in open inland forest and occasionally in open areas in villages on sandy roadsides on Funafuti. Reported present on Nui, Vaitupu and Niulakita by Woodroffe. Seluka (1997) reports that it is used as compost.

Recorded: RRT 1991; RRT \& WAW 1993; SS 1997; RRT 2003; T, F \& F 2010; RRT 2016

Voucher Photographs: DPTV0535, 1014, 2776, 2927, 3267, 3268, 3269, 3654, 3655

\section{Zea mays L.}

Common Names: maize, corn

Tuvaluan Names: kōni (Seluka 1997); kōnu (TvD)

Status: Recent introduction. South, Central and warm North America.

Abundance: Uncommon.

Remarks: Seasonal food crop planted in the PRAP garden in 2003 and on the Taiwan Farm in 2010 and 2016. Cooked as a vegetable and remains fed to livestock or used as mulch.

Recorded: SS 1997; RRT 2003; T, F \& F 2010; RRT 2016

Voucher Photographs: DPTV1159, 2265; DSC02636 


\section{TACCACEAe (Polynesian ArRowroot Family)}

Tacca leontopetaloides (L.) O. Kuntze

Synonyms: Leontice leontopetaloides L.; Tacca pinnatifida Forst.

Common Name: Polynesian arrowroot

Tuvaluan Names: vatia (plant); masoā (flour/starch; Ff; TvD); niu 'a Naleau (Nm)

Status: Aboriginal introduction. Malay archipelago.

Abundance: Uncommon.

Remarks: Occurs spontaneously in houseyard gardens, ruderal sites and inner coastal littoral vegetation. Strangely, it was not reported in any of the surveys by Woodroffe (1991) for Tuvalu or by Koch for Niutao (2002). Potato-like tubers grated, washed and made into a starch used in the past as a supplementary staple or emergency food in most of Polynesia and Micronesia and as a paste or stiffener for tapa cloth in Tonga and Hawai'i (Whistler 2009). Maiden (1904) reports that: "The tuber makes excellent arrowroot, which is well known but seldom made in Funafuti." According to Seluka, the fibers from the flower stalk are used to make hats. Seen present on all visits up until 2010 but not in 2016, possibly because it was not in season.

Recorded: RRT 1991; RRT \& WAW 1993; SS 1997; RRT 2003; T, F \& F 2010

Voucher Photographs: DPTV0895, 2884, 2885, 2933

\section{ZINGIBERACEAE (GINGER FAMILY)}

Alpinia purpurata (Vieill.) K. Schum. Synonyms: Guillainia purpurata Vieill.; Languas purpurata (Vieill.) Kaneh.

Common Name: red ginger

Tuvaluan Name: tinitia (“ginger”; Seluka 1997)

Status: Recent introduction. Indonesia to Pacific Islands.

Abundance: Rare.

Remarks: Planted ornamental with red flowers. Not seen since 2003.

Recorded: RRT 1991; RRT \& WAW 1993; SS 1997; RRT 2003

\section{Alpinia vittata Bull}

Common Name: variegated ginger

Status: Recent introduction. Indonesia to Pacific Islands.

Abundance: Uncommon.

Remarks: Planted ornamental ginger with variegated white and green leaves in the Tuvalu Government Building garden and three other houseyard gardens. Leaves used in garlands and in flower arrangements. Recorded: T, F \& F 2010; RRT 2016

Voucher Photographs: DPTV2502; DSC03359, DSC03361

Costus malortianus H. Wend.

Common Name: stepladder plant

Status: Recent introduction. Costa Rica.

Abundance: Rare or extirpated.

Remarks: Plant seen in one houseyard garden in 2003.

Recorded: RRT 2003

Voucher Photographs: DPTV0943, 0944

Costus speciosus (Koen.) Sm.

Common Names: crepe ginger, Malay ginger, spiral flag

Status: Recent introduction. Malaysia to India.

Abundance: Rare. 
Remarks: Planted ornamental.

Recorded: RRT 1991; RRT \& WAW 1993; RRT 2003; T, F \& F 2010

\section{Costus woodsonii Maas}

Common Names: scarlet spiral flag, red button ginger

Status: Recent introduction. Southern Central America and Colombia.

Abundance: Rare or extirpated.

Remarks: Single potted plant seen in houseyard garden in north Fogafale.

Recorded: T, F \& F 2010

Voucher Photographs: DPTV2716, 2717

\section{Zingiber officinale Roscoe}

Common Names: ginger, common ginger

Status: Recent introduction. India and China.

Abundance: Rare.

Remarks: Reported present by Seluka (1997) and used as a spice and medicine. Not seen by current authors.

Recorded: SS 1997

\section{DICOTYLEDONAE \\ (DICOTYLEDONS)}

\section{ACANTHACEAE (ACANTHUS FAMILY)}

Asystasia salicifolia Craib

Common Name: willow-leaved asystasia

Status: Recent introduction. Thailand.

Abundance: Occasional.

Remarks: Single plant with purple-blue flowers seen in Siliga Kofe's residence and in two other houseyard gardens in 2010 and now seen in a number of houseyard gardens and at the Vaiaku Lagi Hotel in 2016. Widely planted in recent times in flower gardens and landscaping in Suva, Fiji. Flowers worn over ear or in hair as sei and occasionally used in garlands.

Recorded: T, F \& F 2010; RRT 2016

Voucher Photographs: DPTV2934, 3763, 3764, 3776; DSC03200, 03416

Hemigraphis alternata (Burm. f.) T. Anders.

Synonyms: Ruellia alternata Burm. f.; Hemigraphis colorata (Bl.) Hall f.; Ruellia colorata Bl.

Common Name: cemetery plant

Status: Recent introduction. Java.

Abundance: Uncommon.

Remarks: Ornamental pot plant in Hospital matron's garden in 2003; also seen in the garden in the new Government Building in 2010 and 2016 and in the flower beds at the Vaiakulagi Hotel in 2016. Purple leaves occasionally used in garlands.

Recorded: RRT 1991; RRT \& WAW 1993; RRT 2003; T, F \& F 2010; RRT 2016

Voucher Photographs: DPTV3362; DSC03401

Odontonema tubiforme (Bertol.) O. Ktze.

Synonyms: Odontonema strictum (Nees) O. Ktze.; Justicia tubaeformis Bertol.; Thrysacanthus strictus Nees

in DC; O. nitidum (Jacq.) O. Ktze.; Justicia coccinea Aubl.(?)

Common Names: odonotema, red justicia, fire spike

Status: Recent introduction. Central America. 
Abundance: Rare.

Remarks: Planted ornamental in garden outside the Police Headquarters.

Recorded: RRT 2003

Pseuderanthemum carruthersii (Seem.) Guill. var. atropurpureum (Bull) Fosb.

Synonyms: P. atropurpureum (Bull) Radlk.; Eranthemum atropurpureum Bull.; P. versicolor (Hort.) Radlk.; Eranthemum versicolor Hort.

Common Names: purple false eranthemum, false face

Tuvaluan Name: lakau 'uli (Ff); lautagitagi (Nm); suipi kula (Seluka 1997)

Status: Recent introduction. Melanesia?

Abundance: Common. Planted ornamental shrub and hedge plant with dark purplish-red or variegated leaves. Rare as an adventive in south Fogafale Islet. Colored leaves and whole flower stalks used in garlands (fou), wreaths (pale) and for ornamentation and used in wreaths (pale). Seluka reports that the leaves are used for embalming.

Recorded: RRT 1991 (24306); RRT \& WAW 1993 (24157); SS 1997; RRT 2003; T, F \& F 2010; RRT 2016

Voucher Photographs: DPTV0883, 0907, 0931, 1013, 1015, 2143, 2654, 2655, 3371, 3503, 3644, 3645, 3646, 3647, 3648

Pseuderanthemum carruthersii (Seem.) Guill. var. carruthersii

Synonyms: Eranthemum carruthersii Seem.; E. eldorado Hort.; Pseuderanthemum eldorado (Williams) Radlk.

Common Name: false eranthemum

Tuvaluan Name: lakau kena, lakau pula kena (Ff); lau tagitagi (Nm)

Status: Recent introduction. Melanesia?

Abundance: Common.

Remarks: Planted ornamental shrub and hedge or living fence plant with green leaves and attractive flower spike. Flowers and leaves used in head garlands (fou).

Recorded: RRT 1991; RRT \& WAW 1993; RRT 2003; T, F \& F 2010; RRT 2016

Voucher Photographs: DPTV2214, 3643

Pseuderanthemum carruthersii (Seem.) Guill. var. reticulatum (Bull) Fosb.

Synonym: Pseuderanthemum reticulatum (Bull) Radlk.

Common Names: yellow-veined pseuderanthemum, El Dorado

Tuvaluan Name: lakau kena (Ff); lau tagitagi (Nm)

Status: Recent introduction. Melanesia?

Abundance: Common.

Remarks: Planted ornamental shrub and hedge or living fence plant with yellowish upper leaves with a netted or reticulated pattern; also planted in the EEC-funded Global Climate Change Alliance food garden plots in 2016. Seen to be almost naturalized in areas of South Fogafale Islet. Colored leaves and whole flower stalks used in garlands (fou), flower arrangements and plaited together with other flowers in wreaths (pale). Leaves used in garlands and flower arrangements.

Recorded: RRT 1991; RRT \& WAW 1993 (24161); RRT 2003; T, F \& F 2010; RRT 2016

Voucher Photographs: DPTV0875, 2080, 3383, 350, 3505

Ruellia prostrata Poiret

Common Name: prostrate ruellia

Status: Recent introduction. Java.

Abundance: Occasional.

Remarks: Weed seen in the Taiwan ICDF Garden and in flower bed at Tuvalu Government Building in 2010 and 2016. Reported present "only on the northernmost islets" of Funafuti by Maiden (1904). Possibly a mistaken identity, as Whistler (1995) reports that was first recorded from the Pacific Islands in Hawai'i in 1944. 
Recorded: JHM 1904; T, F \& F 2010; RRT 2016

Voucher Photographs: DPTV2501, 3358

Thunbergia erecta (Benth.) T. Anders.

Synonym: Meyenia erecta Benth.

Common Name: bush thunbergia

Status: Recent introduction. Tropical West Africa.

Abundance: Occasional.

Remarks: Planted ornamental with purple-blue trumpet-shaped flowers with yellow throats. Flowers used in head garlands (fou), leis (ula) and flower arrangements and worn over the ear or in the hair as a sei.

Recorded: RRT 1991, 2003; T, F \& F 2010; RRT 2016

Voucher Photographs: DPTV0672, 0673, 2373

\section{AMARANTHACEAE (AMARANTH FAMILY)}

\section{Achyranthes aspera L.}

Common Name: prickly chaff flower

Tuvaluan Name: tamatama (Ff, Nm; Tvd); titi vau (Seluka 1997); sisi vau (Nt, Nui; Koch 2002, Woodroffe 1991)

Status: Aboriginal introduction?

Abundance: Rare or extirpated?

Remarks: Reported present by on Funafuti Islet on Funafuti by Maiden in (1904), but not seen in 1991 or thereafter on Funafuti. Reported present on Nanumea, Nui and Vaitupu by Woodroffe (1991). Known to informants as tamatama and reportedly an important component of traditional dancing garlands (titi vao) along with maile (Microsorum grossum) and sigano, the male flower of pandanus. An important medicinal plant in Tonga where it is used as an antibacterial and blood coagulant to treat wounds (Thaman and Whistler 1996).

Recorded: JHM 1904; SS 1997

Achyranthes canescens $\mathrm{R}$. Br.

Synonym: Achyranthes velutina H. \& A.

Common Name: native prickly chaff-flower

Tuvaluan Name: tamatama (Ff, Nm; Tvd); lautamatama (Seluka 1997); sisi vau, matamata? (Nt; Koch 2002)

Status: Endemic to Polynesia, where it is found in Tuvalu, Tokelau, Swains Island, the Cook, Society, Tuamotu and Austral Islands.

Abundance: Rare.

Remarks: Found in isolated populations of three to six plants under Pisonia groves on Fualopa Islet and on Tepuka Islet in 2003. Also reported present on Niutao by Koch (2002) and Nanumea by Chambers (1984). Probably used in similar ways to Achyranthes aspera. Koch (2002) reports that on Niutao women use the scented reddish flowers for garlands (fau and tiputa vao) and for love spells. Seluka (1997) reports that the plant is used for embalming corpses.

Recorded: RRT \& WAW 1993 (24154); SS 1997; RRT 2003; T, F \& F 2010

Voucher Photographs: DPTV0859, 0860, 0861, 1067, 1069b

Alternanthera brasiliana (L.) Kuntze

Common Name: purple alternanthera

Status: Recent introduction. Tropical South America.

Abundance: Uncommon.

Remarks: Ornamental with dark reddish-purple leaves planted at the TANGO headquarters and in a couple other houseyard gardens in 2010 and in the Vaiakulagi Hotel garden and other houseyard 
gardens in 2016. Dark reddish-purple leaves used in head garlands (fou) and waist garlands (titi) to add color. Has the potential to escape and become weedy on larger high islands.

Recorded: T, F \& F 2011; RRT 2016

Voucher Photographs: DPTV2459, 2693, 3782; DSC02547, 2624

Alternanthera sessilis (L.) R. Br. ex R. \& S.

Synonyms: Gomphrena sessilis L.; Alternanthera denticulata R. Br.; A. nodiflora R. Br.; A. amoena (Lem.) Voss

Common Name: joyweed

Status: Recent introduction. Pantropical.

Abundance: Occasional.

Remarks: Weed in giant swamp taro (Cyrtosperma) pits at Vaiaku and in a number of other moist disturbed sites. Reported present on Nui, Vaitupu and Nukulaelae by Woodroffe (1991).

Recorded: PAM 1989; CDW 1990; RRT 1991 (24327); RRT 2003; T, F \& F 2010; RRT 2016

Voucher Photographs: DPTV2154, 2155, 2168, 3377a

\section{Alternanthera sissoo Hort.}

Common Names: Brazilian spinach, samba spinach, sissoo spinach

Status: Recent introduction. Brazil?

Abundance: Occasional.

Remarks: Food plant found in houseyard gardens. Introduced in the late 1990s from Hawai'i into Kiribati as part of the PRAP Atoll Agriculture Programme to improve nutrition through increasing the supply of leafy vegetables. Cooked as a spinach; low levels of oxalic acid normally require cooking. Although it is referred to scientifically as Alternanthera sissoo Hort., there are no known scientific descriptions of its taxonomy.

Recorded: RRT 2003; T, F \& F 2010; RRT 2016

Voucher Photographs: DPTV0680, 1181, 2192, 2251; DSC03412

Alternanthera tenella Colla

Synonyms: Alternanthera amoena (Lemaire) Reg.; A. ficoidea L. var. bettzickiana (Reg.) Backer; Alternanthera bettzickiana (Reg.) Nichols; A. versicolor Reg.

Common Names: joyweed, alternanthera, calico plant

Status: Recent introduction. Brazil.

Abundance: Rare.

Remarks: Ornamental pot plant in hospital matron's garden in 2003.

Recorded: RRT 2003

\section{Amaranthus hypochondriacus L.}

Synonym: A. hybridus L. var. hypochondriacus (L.) Robins.

Common Name: prince's feather

Status: Recent introduction. Tropical America.

Abundance: Rare.

Remarks: Planted ornamental.

Recorded: RRT 1991

Amaranthus tricolor L.

Synonyms: A. gangeticus L; A. melancholicus L.

Common Names: Joseph's coat, Chinese spinach. amaranth, pigweed

Tuvaluan Names: mōta, moota (from moca in Fijian; Ff)

Status: Recent introduction? Tropical Asia.

Abundance: Occasional. 
Remarks: Planted in houseyard vegetable gardens, the PRAP experimental garden and the Taiwan ICDF

Garden in both 2010 and 2016. Nutritious leafy green vegetable cooked as a spinach to improve nutrition.

There are a number of cultivars, including ornamentals, the nomenclature of which is unclear. A very important spinach in Fiji known as chauraiya in Hindi and moca in Fijian.

Recorded: RRT \& WAW 1993 (24149, 24160); RRT 2003; T, F \& F 2010; RRT 2016

Voucher Photographs: DPTV0531, 0889, 2204, 2205, 2208, 2333, 2334, 2377

\section{Amaranthus viridis L.}

Synonym: Amaranthus gracilis Desf.

Common Names: slender amaranth, green amaranth, pigweed

Status: Recent introduction. Pantropical.

Abundance: Rare.

Remarks: Found growing along the runway near pig and poultry rearing areas. It is used as an emergency spinach, fed to pigs and used for mulch. Not seen since 2003 and possibly threatened by overuse and pigs.

Recorded: RRT 1991 (24317); RRT \& WAW 1993 (24150); SS 1997; RRT 2003

Celosia argentea L. var. cristata (L.) Ktze.

Synonym: C. cristata L.

Common Name: cock's comb

Status: Recent introduction. Tropical Africa.

Abundance: Rare.

Remarks: Erect annual herb with reddish-green leaves and a dense, flatly-crested, elongated, fan-shaped magenta to bright red flower head. Planted ornamental. Also planted for distribution for ornamental houseyard gardening from the Taiwan ICDF garden in 2016.

Recorded: T, F \& F 2010; RRT 2016

Voucher Photographs: DPTV2147, 2148, 2411

\section{Gomphrena globosa L.}

Common Names: globe amaranth, pearly everlasting

Status: Recent introduction. Tropical America.

Abundance: Occasional.

Remarks: Planted ornamental with rounded purple flower heads at new Vaiku Langi Hotel in 2003 and in a number of houseyard gardens and in the Taiwan ICDF Garden in 2010. Flowers used in head garlands (fou).

Recorded: RRT 2003; T, F \& F 2010

Voucher Photographs: DPTV2252, 2348, 2847, 3778c

\section{ANACARDIACEAE (CASHEW OR RHUS FAMILY)}

\section{Mangifera indica L.}

Common Name: mango

Tuvaluan Name: mago (Ff, Nm)

Status: Recent introduction. Indo-Burma.

Abundance: Rare. One immature non-bearing tree about $2.5 \mathrm{~m}$ high seen in garden at Vaiakufou, and one potted immature tree at the Agriculture Department nursery in Vaiaku in 2010. This very popular fruit tree seems to struggle in the harsh atoll environment. Fruit reportedly eaten or fed to livestock and wood used for firewood.

Recorded: RRT 1991; RRT \& WAW 1993; SS 1997; RRT 2003; T, F \& F 2010 


\section{ANNONNACEAE (CUSTARD APPLE FAMILY)}

Annona muricata L.

Common Name: soursop

Tuvaluan Name: saosopu (Seluka 1997)

Status: Recent introduction. Tropical America.

Abundance: Rare.

Remarks: Single mature tree with no fruit seen in the Agricultural Department nursery in Vaiaku. Does not seem to be adapted to the harsh atoll environment.

Recorded: RRT 1991; RRT \& WAW 1993; SS 1997; RRT 2003; T, F \& F 2010

\section{Annona squamosa L.}

Common Name: sweetsop, sugar apple

Tuvaluan Name: nameana, kasitati apolo (Seluka 1997)

Status: Recent introduction. Tropical America.

Abundance: Uncommon.

Remarks: Single seedling seen 1991 in a food garden; reportedly introduced by the Matron of the Hospital by seed from Fiji. Planted in the Taiwan ICDF Garden in 2010 and seen as a mature tree in 2016.

Recorded: RRT 1991; SS 1997; T, F \& F 2010; RRT 2016

Voucher Photographs: DPTV1028, 1029, 1161a, 2307, 2308; DSC02656

\section{APIACEAE (CELERY/CARROT FAMILY)}

\section{Apium graveolens L.}

Common Name: celery

Tuvaluan Name: silalii, silalī (Seluka 1997)

Status: Recent introduction. Eurasia.

Abundance: Rare.

Remarks: Vegetable planted in the Taiwan ICDF Garden in 2010.

Recorded: SS 1997; T, F \& F 2010

Voucher Photograph: DPTV2336

Centella asiatica (L.) Urban

Common Name: Asiatic pennywort

Status: Recent introduction? Pantropical and subtropical, but probably a recent or aboriginal introduction to Tuvalu.

Abundance: Uncommon.

Remarks: Occasional weed or protected plant in houseyard gardens, along shady roadsides and in planting boxes at the old Vaiaku Lagi Hotel lagoonside bar and in a couple of sites in north Fogafale, one where it is spreading and healthy at cemetery near the main wharf and another extensive patch in the same area along the roadside just south of the Teone Catholic Church on north Fogafale Islet. It is an important medicinal plant in Tonga, Samoa and Fiji (Whistler 1991, 2000a), although informants in 2010 and 2016 did not have a name for it.

Recorded: RRT 1991, 2003; T, F \& F 2010; RRT 2016

Voucher Photographs: DPTV1005, 1006, 2248, 2249, 2941, 2942, 2944, 2945, 2946; DSC03290, DSC03292, DSC03293

\section{Coriandrum sativum L.}

Common Names: coriander, cilantro, Chinese parsley

Status: Recent introduction. Southern Europe and the Mediterranean region.

Abundance: Uncommon. 
Remarks: Pot herb used in Chinese and Indian cooking. Planted in the Taiwan ICDF Garden in 2010. Recorded: T, F \& F 2010

\section{Daucus carota L.}

Common Name: carrot

Tuvaluan Name: keloti (Seluka 1997)

Status: Recent introduction. Europe, Asia and Africa.

Abundance: Occasional.

Remarks: Seedlings planted in PRAP experimental nursery and in the Taiwan ICDF garden. Periodically planted from seed.

Recorded: SS 1997; RRT 2003

\section{APOCYNACEAE (DOG-BANE FAMILY)}

Catharanthus roseus (L.) G. Don

Synonyms: Vinca rosea L.; Lochnera rosea (L.) Reichenb.

Common Names: periwinkle, Madagascar periwinkle

Tuvaluan Name: peteli, peteli kula (Ff, Nm; Tvd); peteli kena (Ff); peteli tea (Nm); losa, losa kula, losa piniki (Ff, Nm); losa kena (Ff); losa tea (Nm); loosi tai (Seluka 1997)

Status: Recent introduction. Madagascar.

Abundance: Common.

Remarks: Planted ornamental in houseyard and institutional gardens. A range of white, pink and red flowered cultivars exist. Flowers used in head garlands (fou) and other body and household ornamentation. Seluka reports it is used as an ingredient for embalming corpses.

Recorded: RRT 1991; RRT \& WAW 1993; SS 1997; RRT 2003; T, F \& F 2010; RRT 2016

Voucher Photographs: DPTV0570a, 0571, 0940, 2039, 2355, 2719, 2846, 3502; DSC03202

Nerium oleander L.

Common Name: oleander

Status: Recent introduction. Southern Europe to Iran.

Abundance: Uncommon.

Remarks: Ornamental shrub with white, pink or purple flowers. Planted at hotel and in a number of houseyard gardens. Flowers used in garlands and decorations. All parts of the plant are poisonous and can be cause death if ingested.

Recorded: RRT 1991; RRT \& WAW 1993; SS 1997; RRT 2003; T, F \& F 2010; RRT 2016

Voucher Photograph: DPTV0880

Ochrosia oppositifolia (Lam.) K. Schum.

Synonym: Neisosperma oppositifolium (Lam.) Fosb. \& Sachet

Tuvaluan Names: fao (Ff, Nm; Tvd); paopao, paupau (Nui; Woodroffe 1991)

Status: Indigenous. Philippines to Southeastern Polynesia and Micronesia.

Abundance: Common.

Remarks: A dominant species in inland secondary woodland on north and south Fogafale Islet and uncommon in houseyard gardens. Was reportedly uncommon on Funafuti in 1898 by Maiden (1904). Reported from all Tuvalu atolls except Niulakita. Koch (2002) reports that on Niutao the wood is used for house posts and rafters; the small almond-like edible kernels inside the fruit are eaten as a snack food and, in times of food shortage, served as a substitute for coconut. The leaves are used as manure or mulch (kaiao) in taro pits (pela) and the colorful flowers are used in head garlands (fou), other garlands and worn over the ear or in the hair as sei (Woodroffe 1991).

Recorded: CH 1896; JHM 1904; RRT 1991; RRT \& WAW 1993; SS 1997; RRT 2003; T, F \& F 2010; RRT 2016

Voucher Photographs: DPTV0561, 0967, 0968, 0969a, 0970, 2777, 2778, 2779, 2781, 2810, 2811, 3332a 


\section{Plumeria obtusa L.}

Common Names: white frangipani, plumeria

Tuvaluan Names: pua Fiti Solomona (Ff); melia Solomona ("frangipani from Solomon Islands”; Nm)

Status: Recent introduction. Tropical America.

Abundance: Common.

Remarks: Planted ornamental with large fragrant white flowers with yellow throats and dark-green evergreen leaves with rounded tips. Planted in houseyard gardens and landscaping. Flowers used in head garlands (fou), leis (ula), waist garlands (titi), flower arrangements and worn over the ear or in the hair as a sei. Flowers also used to scent coconut oil (sinu). The name means the frangipani (pua Fiti) from Solomon Islands, with the name pua Fiti, which means the fragrant flower from Fiji, being the general name for frangipani in Funafuti and the southern atolls, whereas melia is the name for frangipani in Nanumea and the northern islands, a name which is derived from the Kiribati name te meria which is probably derived from the Hawaiian name pua melia.

Recorded: RRT 1991; RRT \& WAW 1993; RRT 2003; T, F \& F 2010; RRT 2016

Voucher Photographs: DPTV0640, 0641, 1165, 2528, 2529, 2665, 2666; DSC02517, DSC02521

\section{Plumeria rubra L.}

Synonyms: Plumeria acuminata Ait. f. and P. acutifolia Poir.

Common Names: frangipani, plumeria, temple tree, graveyard tree

Tuvaluan Names: pua Fiti (“Fiji”; Ff; TvD); melia (Nm; TvD); pua Fiti Nalu (“Nauru”; Ff); melia Nalu (Nm); pua Fiti Tuvalu (Ff); pua Fiti kula (Ff); melia kula (Nm)

Status: Recent introduction. Tropical America.

Abundance: Abundant.

Remarks: Planted ornamental in houseyard gardens and landscaping. Tree with deciduous pointed grey-green leaves and a range of flowers colors from white with yellow throats to pink, orangish and dark red. Flowers used in head garlands (fou), leis (ula), waist garlands (titi), flower arrangements and worn over the ear or in the hair as a sei. Flowers also used to scent coconut oil (sinu).

Recorded: RRT 1991; RRT \& WAW 1993; SS 1997; RRT 2003; T, F \& F 2010; RRT 2016

Voucher Photographs: DPTV0876, 2055, 1166, 1176, 2124, 2139, 2140, 2354, 2496, 2525, 2526, 2527, 2659, 2760, 2761, 2762, 2768, 2769, 2829, 2940a, 3704, 3705

Tabernaemontana divaricata (L.) R. Br.

Synonyms: Nerium divaricatum L.; N. coronarium Jacq.; Tabernaemontana coronaria (Jacq.) Willd.; Ervatamia divaricata (L.) Burkill; E. coronaria (Jacq.) Stapf

Common Names: false gardenia, paper gardenia, crepe jasmine, scentless gardenia

Status: Recent introduction. India.

Abundance: Occasional.

Remarks: Large shrub with shiny green leaves and small nearly odorless gardenia-like white flowers. Planted in the Tuvalu Government Building garden; seen again as mature plants at Government Building and in a number of houseyard gardens in 2016. Planted ornamental; white flowers used in head garlands (fou), other body ornamentation and worn as sei over the ear or in the hair by females.

Recorded: T, F \& F 2010; RRT 2016

Voucher Photographs: DPTV2063, 2267, 2948, 3359, 3360; DSC02670, 2961, 2963

\section{Araliaceae (Panax Family)}

Polyscias filicifolia (C. Moore ex. Fourn.) L. H. Bailey

Synonym: Polyscias cumingiana (Presl.) Fern.-Vill.

Common Names: golden prince panax, fern-leaf aralia, angelica

Tuvaluan Name: lautagatagi? (Ff)

Status: Recent introduction. Malesia, possibly to Melanesia.

Abundance: Occasional. 
Remarks: Erect shrub with bright yellow mature upper leaves. Planted ornamental in houseyard gardens and the Vaiaku Lago Hotel garden. Leaves used in body ornamentation and decorations; the yellow-green leaves are used instead of Premna (valovalo) in head garlands (fou) because of their agreeable fragrance. Recorded: RRT 1991; RRT \& WAW 1993; RRT 2003; T, F \& F 2010; RRT 2016

Voucher Photographs: DPTV0873, 2078

Polyscias fruticosa (L.) Harms

Synonyms: Panax fruitcosum L.; Nothopanax fruticosus (L.) Miq.

Common Names: parsley panax, hedge panax

Tuvaluan Names: lautagitagi (Ff, Nm); lautagitagi laulikiliki (“very small-leaved”; Ff); kai mamara (Seluka 1997)

Status: Recent introduction. India to Western Polynesia.

Abundance: Common.

Remarks: Ornamental commonly planted as a hedge or living fence. Stems sometimes used for firewood and leaves for garlands. The leaves can be used instead of Guettarda and Premna leaves in head garlands (fou) because of their agreeable fragrance.

Recorded: RRT 1991; RRT \& WAW 1993; SS 1997; RRT 2003; T, F \& F 2010; RRT 2016

Voucher Photographs: DPTV0523, 0941, 2180, 2181, 3694, 3695

Polyscias guilfoylei (Cogn. \& March.) Bailey

Synonyms: Aralia guilfoylei Cogn. \& March.; Nothopanax guilfoylei (Cogn. \& March.) Merr.

Common Names: panax, hedge panax

Tuvaluan Name: lautagitagi (Ff, Nm)

Status: Recent introduction. Melanesia.

Abundance: Abundant.

Remarks: Ornamental shrub commonly planted as a hedge or living fence. Stems sometimes used as fuel and leaves used as mulch; leaves sometimes used in waist garlands (titi) for dancers. In the 1980s, the consumption of the young leaves was encouraged in Kiribati and Tuvalu to increase vitamin A and iron in diets of children.

Recorded: RRT 1991; RRT \& WAW 1993; SS 1997; RRT 2003; T, F \& F 2010; RRT 2016

Voucher Photographs: DPTV0884, 1169, 2649, 2650, 2651, 2815, 2816

Polyscias scutellaria (Burm. f.) Fosb.

Synonyms: Crassula scutellaria Burm. f.; Polyscias pinnata J. R. \& G. Forst.; Nothopanax scutellaria (Burm. f.) Merr.; Polyscias balfouriana (Sander ex André) L.H. Bailey

Common Names: panax, hedge panax

Tuvaluan Name: lautagitagi (Ff, Nm)

Status: Recent introduction. Southeast Asia.

Abundance: Very abundant.

Remarks: Ornamental plant in hedgerows or living fences. Leaves used in waist garlands (titi) for dancers. Young leaves occasionally used as spinach after scalding in boiling water, chopping into pieces and mixing with onions and coconut cream. An uncommon cultivar, Tricochleata, with divided, sharply toothed margins is also present.

Recorded: RRT 1991; RRT \& WAW 1993; RRT 2003; T, F \& F 2010; RRT 2016

Voucher Photographs: DPTV0631, 1131, 1134, 1167b, 2115, 2116, 2138, 2183, 3489b, 3492

\section{ASCLEPIADACEAE (MILKWEED FAMILY)}

\section{Asclepias curassavica L.}

Common Names: milkweed, butterfly weed, red cotton bush, bloodflower

Status: Recent introduction. Tropical America.

Abundance: Extirpated. 
Remarks: Planted ornamental and roadside weed seen and recorded present in 2010 but not seen since; was reportedly quite common and well-known in the 1970s and before, but now extirpated. Also common in the past in Kiribati and Nauru, where it was known as dupaimdupaim (Thaman et al. 1994). Flowers used for body ornamentation and making garlands. Reportedly poisonous to livestock.

Recorded: T, F \& F 2010

\section{ASTERACEAE (ASTER, SUNFLOWER OR DAISY FAMILY)}

Adenostemma lanceolatum Miq.

Synonym: Adenostemma lavenia sensu auct. Micr. non (L.) O. Ktze.

Common Name: adenostema

Tuvaluan Names: mili; lipilipi (Koch 2002); kisikisi? (Maiden 1904)

Status: Indigenous? Pantropical, possibly of Tropical American origin.

Abundance: Rare or extirpated on Funāfuti.

Remarks: Reported present by Maiden (1904) on Funāfuti and from Niutao by Koch (2002), where it was apparently common in the past, and on Nui by Woodroffe (1997). Reportedly used as a medicine to treat haemoptysis on Niutao by Koch (2002).

Recorded: CDW 1991

Bidens alba (L.) DC.

Synonyms: Coreopsis alba L.; C. leucanthema L.; C. leucantha L.; Bidens pilosa L. var. radiata sensu auct. non Sch.-Bip.; B. leucantha (L.) Willd.

Common Names: cobbler's peg, Spanish needle

Status: Recent introduction. Tropical America.

Abundance: Rare.

Remarks: Weed with white daisy-like flowers with yellow center florets. Found in one localized concentration to the east of the airfield next to the PRAP experimental garden. Has the potential to spread rapidly as it has on Majuro Atoll in the Marshall Islands. Flowers used in garlands.

Recorded: RRT \& WAW 1993 (24159, 24163); RRT 2003; T, F \& F 2010; RRT 2016

Voucher Photographs: DPTV2360, 2365, 2366, 2367

Cyanthillium cinereum (L.) H. Rob.

Synonym: Vernonia cinerea (L.) Less.

Common Name: iron weed, little iron weed

Tuvaluan Name: mouku fai pula (Ff, Nm)

Status: Recent introduction. Tropical Asia.

Abundance: Common.

Remarks: Weed of roadsides, waste places and ruderal sites. Reported present on most of the other atolls of Tuvalu. Plants used for compost.

Recorded: CDW 1991; RRT 1991; RRT \& WAW 1993; SS 1997; RRT 2003; T, F \& F 2010; RRT 2016

Voucher Photographs: DPTV0671, 2026, 2081, 1132, 3541b, 3754

Eclipta prostrata (L.) L.

Synonym: Eclipta alba (L.) Hassk.

Common Name: false daisy

Status: Recent introduction. Tropical Asia, now pantropical weed.

Abundance: Rare.

Remarks: Weed near base of buildings at the deepwater harbor in 1993 and in a number of other sites. Not seen in 2010 or 2016. Reported present on Nui by Woodroffe (1991).

Recorded: CDW 1991; RRT \& WAW 1993 (24159 or 24163?); RRT 2003

Voucher Photographs: DPTV0515, 0669, 0670 
Emilia fosbergii Nicholson

Common Names: red sow thistle, Fosberg's sow thistle, Fosberg's red paintbrush

Status: Recent introduction. Pantropical.

Abundance: Rare, possibly extirpated.

Remarks: Single weed population along east side of airstrip. Not seen since 1993.

Recorded: RRT 1991 (24307); RRT \& WAW 1993 (24158)

Gynura bicolor (Roxb. ex Willd.) DC

Common Names: Okinawan spinach, gynura

Status: Recent introduction. Moluccas.

Abundance: Rare, now possibly extirpated.

Remarks: Planted at PRAP experimental nursery. Food plant introduced by the PRAP Atoll Agricultural Programme as a nutritious cooked vegetable in the 1990s. Not seen in 2010 and 2016.

Recorded: RRT 2003

Lactuca sativa L. vars.

Common Name: lettuce

Tuvaluan Name: letisi (Ff)

Status: Recent introduction. Europe.

Abundance: Common. Seasonal food plant in home food gardens and uncommon in 2010, but common with a number of varieties planted in the Taiwan ICDF Garden in 2016. Sold on a weekly basis to restaurants, hotels and the public.

Recorded: RRT 1991; SS 1997; RRT 2016

Voucher Photographs: DSC02615, DSC02629, DSC02631, DSC02632, DSC02633

Mikania micrantha Kunth

Common Name: mile-a-minute, mile-a-minute vine

Tuvaluan Names: saketa lauliki (Ff); mouku Amelika (“American weed”; Nm)

Status: Recent introduction. Tropical America.

Abundance: Common, and spreading.

Remarks: Weed in open lot on fence at the Police Headquarters, in ruderal sites bordering airfield, and in excavated giant swamp taro (Cyrtosperma) pits (pela) in Vaiaku 1991. Widespread on Fogafale Islet in 2010 and in 2016. Apparently introduced by the American forces who were based on Nanumea during WWII. A serious invasive weed in Fiji and other areas of the Pacific. The crushed leaves are used medicinally in Fiji as one of the most effective anti-bacterials and blood coagulants to treat deep cuts and wounds.

Recorded: RT \& WAW 1993; RRT 2003; T, F \& F 2010; RRT 2016

Voucher Photographs: DPTV0530, 2117, 2165, 3377b, 3380, 3432, 3433, 3436

Pluchea carolinensis (Jacq.) G. Don

Synonyms: Pluchea odorata (L.) Cass; P. symphytifolia (Mill.) Gillis

Common Name: pluchea, shrubby fleabane, sourbush

Tuvaluan Names: mili; lakau Amelika (“American plant”; Seluka 1997)

Status: Recent introduction. Tropical America.

Abundance: Occasional.

Remarks: Weed of ruderal sites, wasteplaces and in excavated taro garden areas (pela); most common in areas bordering the airstrip. Fragrant leaves used to scent coconut oil (sinu).

Recorded: RRT 1991; RRT \& WAW 1993; SS 1997; RRT 2003; T, F \& F 2010

Voucher Photographs: DPTV05014, 0527, 0699, 0700, 2218, 2475, 2569, 2570, 3415, 3416

Pluchea indica (L.) Less.

Common Name: Indian pluchea 
Tuvaluan Name: mili

Status: Recent introduction. Southern Asia.

Abundance: Occasional. Weed of roadsides and waste places. Seen along the east margins of the airstrip north of the Taiwan ICDF Garden. Fragrant leaves used to scent coconut oil (sinu), sometimes by cooking it with the oil.

Recorded: RRT 1991; RRT \& WAW 1993 (24301); SS 1997; RRT 2003; T, F \& F 2010

Voucher Photographs: DPTV2389, 2390, 2391, 2456, 2457, 2710

\section{Senecio chenopodioides HBK}

Synonyms: Senecio confusus Britt.; Pseudogynoxis chenopodioides (HBK) Cabrera

Common Names: Mexican flame vine, orange-flowered senecio

Status: Recent introduction. Mexico.

Abundance: Uncommon.

Remarks: Pot plant in hospital matron's garden and at the Vaiaku Lagi Hotel and in a number of other gardens in Vaiakufou in 2003. Climbing plant with bright orange daisy-like flowers. Not seen in 2010 or 2016.

Recorded: RRT 1991 (24305); RRT \& WAW 1993; RRT 2003

Voucher Photographs: DPTV0877, 878, 0933

Sphagneticola trilobata (L. C. Rich) Pruski.

Synonyms: Silphium trilobatum L.; Wedelia trilobata (L.) Hitchc.

Common Names: Creeping daisy, wedelia, trailing daisy, water zinnia, Bay Biscayne creeping ox-eye, Singapore daisy

Tuvaluan Name: mouku solo (Ff)

Status: Recent introduction. Central America, Caribbean and northern South America.

Abundance: Abundant.

Remarks: Perennial creeping herb with bright green three-lobed, toothed leaves and bright yellow daisy-like flowers. Planted ornamental groundcover that has naturalized and become very invasive in many sites along roadsides, in coastal vegetation and near the excavated taro gardens near the airport on both north and south Fogafale Islet. Where possible, it should be removed and, if not too late, its introduction to other atoll and uninhabited islets restricted. A very serious invasive weed in most Pacific Island countries and listed as one of the world's 100 worst invasive species (Thaman 1999, 2011). Bright yellow flowers used in head and neck garlands (fou and ula) and vinelike stems woven into garlands.

Recorded: RRT 1991; RRT \& WAW 1993; RRT 2003; T, F \& F 2010; RRT 2016

Voucher Photographs: DPTV0511, 0533, 0542, 0543, 0554, 0600a, 0607, 0663, 0664, 0704, 0913, 0918, 0922, 1024, 2104, 2197, 2205, 2228, 2588, 3458, 3468, 3469, 3470, 3471, 3472, 3473, 3474, 3475, 3585, 3729

Synedrella nodiflora (L.) Gaertn.

Synonym: Verbesina nodiflora L.

Common Name: synedrella, nodeweed

Tuvaluan Name: mouku (general term for grasses and small weeds)

Status: Recent introduction. Tropical America.

Abundance: Very abundant.

Remarks: Weed of waste places, gardens, roadsides, path sides and ruderal sites. Plants used for mulching.

Recorded: RRT 1991; RRT \& WAW 1993; SS 1997; RRT 2003; T, F \& F 2010; RRT 2016

Voucher Photographs: DPTV0677, 1174, 2029, 2107, 2123, 2564, 3459, 3691

\section{Tagetes erecta L.}

Common Names: marigold, Aztec marigold, African marigold

Status: Recent introduction. Mexico.

Abundance: Occasional. 
Remarks: Planted annual ornamental. Flowers used in leis and garlands and for decoration; also planted in vegetable gardens as a natural insect repellent.

Recorded: RRT 1991; RRT 2003; T, F \& F 2010

Voucher Photographs: DPTV2422, 2423, 2850, 3778a

Tridax procumbens L.

Common Names: wild daisy, coat buttons

Tuvaluan Name: mouku fai pula (Ff, Nm)

Status: Recent introduction. Tropical America.

Abundance: Common.

Remarks: Weed on roadsides, waste areas, ruderal sites, grassy areas and lawns and occasionally near beaches.

Recorded: RRT 1991; RRT \& WAW 1993; RRT 2003; T, F \& F 2010; RRT 2016

Voucher Photographs: DPTV 1164, 0652, 2097, 2770, 3366, 3706, 3707, 3715

Wollastonia biflora (L.) DC.

Synonym: Wedelia biflora (L.) DC.

Common Name: beach sunflower

Tuvaluan Names: ateate (Seluka, 1997); lakau o galiga (Koch 2002) ; lakau manogi (lakou monogi in Maiden 1904)

Status: Indigenous. Tropical Asia to Polynesia and Micronesia.

Abundance: Rare.

Remarks: Reported present on Funafuti by Hedley (1894) and Maiden (1904). Normally found in strand and ruderal sites on ocean and lagoon shores on atolls, such as Majuro in the Marshall Islands, and although reported to be possibly present by Seluka (1997), without a specific location, it was not seen by current authors. Reported present on Niutao by Koch (2002) and on Nui by Woodroffe (1985). Koch (2002) reports that the leaves are used to scent coconut oil (sinu) on Niutao. Flowers used in garlands. It is an important medicinal plant in Tonga and Fiji, where it is known as ate and kovekove, respectively.

Recorded: CH 1896; JHM 1904; SS 1997

Zinnia elegans Jacq.

Common Name: zinnia

Status: Recent introduction. Mexico.

Occasional, but seasonal. Seasonal planted ornamental in houseyard gardens. Flowers used in garlands, especially many-flowered Cook Island style head garlands (fou). Reported by Seluka (1997) to be used for embalming corpses.

Recorded: RRT 1991; SS 1997; RRT 2003

Voucher Photographs: DPTV, 2258, 2411, 2412, 2432, 2869, 2872, 2873, 3768, 3778d

\section{BALSAMINACEAE (BALSAM FAMILY)}

\section{Impatiens balsamina L.}

Common Names: balsam, garden balsam

Status: Recent introduction. India or Africa.

Abundance: Rare.

Remarks: Planted ornamental. Not seen since 2003.

Recorded: RRT 2003 


\section{BARRINGTONIACEAE OR LECYTHIDACEAE (BRAZILNUT FAMILY)}

Barringtonia asiatica (L.) Kurz.

Synonyms: Mammea asiatica L.; Barringtonia speciosa Forst.; B. butonica Forst.

Common Names: fish-poison tree, barringtonia

Tuvaluan Names: futu (Ff, Nm; Tvd); kafutu (Ng; Tvd; Seluka 1997); kafuti (Ni; Koch 2002); ulu (Nui; Woodroffe 1991)

Status: Indigenous. Indo-Pacific.

Abundance: Occasional.

Remarks: Uncommon in lagoon coast vegetation on main and outer islets. Planted in houseyard gardens and as a roadside tree in Vaiaku along the road south of the airport. One large tree seen in lagoon coast forest on the south end of Fogafale Islet and another bordering the mangrove and lagoon area just north of the Public Works compound east of the airfield. Some trees possibly planted from drift seeds or drift seedlings. Also seen the Agricultural Department nursery in 2016. Reported present on all other atolls except for Nanumaga and Niulakita by Woodroffe (1991). Mrs. David (1899) reported that, in 1898, "There is one small grove of these trees on the main Funafuti islet." Seeds grated in the past for use as a fish poison; leaves used for mulching; and wood for paddles and house posts on Niutao. An important tree for coastal stabilization.

Recorded: JHM 1904; CDW 1991; RRT 1991; RRT \& WAW 1993; RRT 2003; T, F \& F 2010; RRT 2016

Voucher Photographs: DPTV0698, 1000, 1001b, 1002, 2291, 2789, 3509, 3510, 3511, 3514, 3583; DSC02583

\section{BASELLACEAE (BASELLA FAMILY)}

Basella rubra L.

Synonym: Basella alba L.

Common Names: Indian spinach, Ceylon spinach, Malabar nightshade

Status: Recent introduction. Tropical Asia.

Abundance: Rare.

Remarks: Creeping or climbing food plant at PRAP experimental nursery. Leaves cooked as a spinach in Fiji by Indians and Chinese.

Recorded: RRT 2003

\section{BEGONIACEAE (BEGONIA FAMILY)}

\section{Begonia sp.}

Common Name: begonia cultivar

Status: Recent introduction. Tropical America.

Abundance: Occasional.

Remarks: Planted ornamental in the University of the South Pacific center garden in 2003.

Recorded: RRT 2003

Voucher Photographs: DPTV1135

\section{BIGNONIACEAE (BIGNONIA FAMILY)}

Tecoma stans (L.) Juss. ex HBK.

Synonyms: Bignonia stans L.; Stenolobium stans (L.) D. Don

Common Names: yellow elder, yellow bells, tecoma, ginger Thomas

Tuvaluan Names: nikilailai (from Kiribati nei karairai; Ff, Nm); pele sama (Seluka 1997)

Status: Recent introduction. Tropical America.

Abundance: Occasional. 
Remarks: Planted ornamental with bright-yellow, bell-shaped flowers; occasionally planted in hedges.

Flowers used in head garlands (fou), leis (ula), waist garland (titi) and worn as sei over the ear or in the hair. Wood uncommonly used for fuel. Much less common than in the past.

Recorded: RRT 1991; RRT \& WAW 1993; SS 1997; RRT 2003; T, F \& F 2010; RRT 2016

Voucher Photographs: DPTV1003, 1004, 1007, 2936, 3670, 3671, 3672, 3673, 3674, 3675, 3676, 3677, 3678

\section{BORAGINACEAE (HELIOTROPE FAMILY)}

\section{Cordia sebestena L.}

Common Names: geiger tree, sebesten plum

Tuvaluan Name: kānava pālagi (Ff)

Status: Recent introduction. West Indies and probably the coasts of northern South America.

Abundance: Occasional.

Remarks: Planted ornamental tree near the Government Centre, the airport, the Prime Minister's residence and in a few other sites. Bright red-orange flowers used in head garlands (fou) and other ornamentation; flowers strung on coconut leaflet midribs (tuaniu); wood occasionally used for fuel.

Recorded: RRT 1991; RRT \& WAW 1993; SS 1997; RRT 2003; T, F \& F 2010; RRT 2016

Voucher Photographs: DPTV, 1183, 2495, 2837, 2838, 2839, 2840; DSC02676, 2678, 2680

\section{Cordia subcordata Lam.}

Common Names: sea trumpet, kou (Hawaii)

Tuvaluan Name: kānava (Ff, Nm, Nt, Nui; Tvd)

Status: Indigenous. Indian Ocean to Hawaii.

Abundance: Occasional.

Remarks: Uncommon in coastal strand forest and in inland woodland and disturbed areas. More common on uninhabited offshore islets and other atolls. Occasional in houseyard gardens and there are a number of large trees found in the main settlement of Vaiaku. Important tree for coastal protection, providing shade, and as habitat for seabirds. One of Tuvalu's most important cultural trees. The attractive and durable wood is used for house posts, furniture and by woodcarvers for making climbing sticks, paddles, drums or slit-gongs (lali), traditional wooden pillows or headrests (lali) and other items. The beautiful orange, lightly-scented, flowers are used in head and neck garlands (fou and ula) and often strung on coconut leaflet midribs (tuaniu). The bark and other parts of the tree are used medicinally and in traditional magic. However, in mid-2010, the trees on Nanumea Atoll in northern Tuvalu were attacked by an epidemic outbreak of kou leaf-worm, the caterpillar of an introduced moth (Ethmia nigroapicella). By mid-2011 most of the trees in the main settlement were close to death, constituting a serious national disaster (Thaman and O'Brien 2011). Extensive groves of Cordia were also devastated in Hawai'i in the 1880s by kou leaf-worm and although many have recovered the tree has been replaced in many places by the non-indigenous Cordia sebestena (Friday and Okano 2006).

Recorded: JHM 1904; RRT 1991; RRT \& WAW 1993; SS 1997; RRT 2003; T, F \& F 2010; RRT 2016

Voucher Photographs: DPTV05012, 0793, 0982, 0984, 1002a, 1078, 1107b, 1121, 1122, 2161, 2618, 2903, 3021, 3135, 3265, 3270, 3476; DSC02449, 02450

Tournefortia argentea L. f.

Synonyms: Messerschmidia argentea (L.f.) I.M. Johnst.; Argusia argentea (L.f.) Heine; Tournefortia sericea Cham.

Common Name: beach heliotrope

Tuvaluan Names: tausunu (Ff, Nt, Nui; TvD); tauhunu (Nm; TvD)

Status: Indigenous. Indian Ocean to Southeastern Polynesia.

Abundance: Common, but rare on Fogafale, the main islet of Funafuti Atoll due to overuse and land reclamation. 
Remarks: Occasional in strand forest on ocean and lagoon shores on main islets on other atolls and common on uninhabited islets (motu). Occasional around excavated taro pit areas (pela), some coconut plantations, in houseyard gardens. Reported present from all atolls in Tuvalu. Plays a very important role in stabilizing beaches and coastlines and is a very important nesting or rookery species for seabirds. The very hard wood is used for carving canoe connectives, coconut graters and other implements, and used as firewood. Its leaves are one of the most important types of mulch or compost (kaiao) for taro pit gardens (pela). An important medicinal plant with the roots, bark and other parts used medicinally, especially for women's medicine and as a deodorant. Leaves mixed with coconut milk are used by women to dye hair black and by young women to make their hair black, thicker and grow longer (Koch 2002). The flower stalks are sometimes plaited together to make head garlands (fou).

Recorded: CH 1896; JHM 1904; CDW 1991; RRT 1991; RRT \& WAW 1993; SS1997; RRT 2003; T, F \& F 2010; RRT 2016

Voucher Photographs: DPTV0593, 0665, 0666, 0740, 0761, 0772, 0832, 0839, 0993, 0994, 1046, 1109, 1110, 1111, 1112, 1114, 3017, 3018, 3022, 3040a, 3041a, 3042a, 3077a, 3078, 3079a, 3141, 3153, 3157, 3174, 3175, 3178, 3302a, 3303a, 3311b, 3312b, 3313b, 3314b, 3315b, 3316b, 3317b

\section{BRASSICACEAE OR CRUCIFERAE (CABBAGE OR MUSTARD FAMILY)}

Brassica chinensis L. var. chinensis

Synonym: Brassica chinensis Juslenius

Common Names: Chinese cabbage, Chinese white cabbage

Tuvaluan Name: kapisi Saina ("Chinese cabbage”; Ff, Nm)

Status: Recent introduction. Asia.

Abundance: Common.

Remarks: Planted in small houseyard food gardens promoted by the Family Food and Nutrition program and the Agricultural Department and planted in the Taiwan ICDF Garden in 2010 and 2016 from where it is sold to the public, restaurants and hotels on a weekly basis. Leaves cooked in soups and Chinese dishes, especially in the few local Chinese restaurants. Leftovers are fed to livestock or used as mulch.

Recorded: RRT 1991; RRT \& WAW 1993; SS 1997; RRT 2003; T, F \& F 2010; RRT 2016

Voucher Photographs: DPTV2127; DSC02610

Brassica chinensis L. var. parachinensis (Bailey) Tsen and Lee

Synonyms: Brassica parachinensis Bailey; B. chinensis var. oleifera Makino

Common Name: flowering white cabbage

Tuvaluan Name: kapisi Saina ("Chinese cabbage”; Ff, Nm)

Status: Recent introduction. Asia.

Abundance: Uncommon.

Remarks: Cultivated in the Taiwan ICDF Garden in 2010 and 2016. Same uses as Brassica chinensis var. chinensis.

Recorded: T, F \& F 2010; RRT 2016

Voucher Photograph: DPTV2430

Brassica juncea (L.) Czern.

Synonym: Sinapis juncea L.

Common Names: mustard cabbage, Indian mustard, Chinese mustard

Tuvaluan Name: kapisi Saina (“Chinese cabbage”; Ff, Nm)

Status: Recent introduction. Asia.

Abundance: Occasional.

Remarks: Planted in household vegetable gardens and in the Taiwan ICDF Garden. Same uses as Brassica chinensis.

Recorded: RRT 1991; RRT \& WAW 1993; RRT 2003; T, F \& F 2010

Voucher Photographs: DPTV2335, 2337 
Brassica oleracea L. Acephala Group

Common Name: kale

Tuvaluan Name: kapisi Palagi

Status: Recent introduction. Europe or Asia.

Abundance: Rare.

Remarks: Planted in 2010 in the Taiwan ICDF Garden.

Recorded: T, F \& F 2010; RRT 2016

Voucher Photographs: DPTV2315, 2322

Brassica oleracea L. var. botrytis L.

Common Name: cauliflower

Status: Recent introduction. Europe.

Abundance: Uncommon.

Remarks: Planted in 2010 and 2016 in the Taiwan ICDF Garden from where it is sold to the public, restaurants and hotels on a weekly basis.

Recorded: T, F \& F 2010; RRT 2016

Voucher Photographs: DPTV2352, 2395, 2426; DSC02607

Brassica oleracea L. var. capitata L.

Common Name: English cabbage

Tuvaluan Names: kapisi pukupuku (“round”; Ff, Nm); kapisis palagi (Seluka 1997)

Status: Recent introduction. Europe.

Abundance: Uncommon.

Remarks: Food plant in houseyard food gardens; one purple cabbage seen in Prison food garden in 2003; planted in 2010 and 2016 in the Taiwan ICDF Garden. Cooked in soups, Chinese dishes and made into salad, cold slaws or garnishes.

Recorded: RRT 1991; RRT \& WAW 1993; SS 1997; RRT 2003; T, F \& F 2010; RRT 2016

Voucher Photographs: DPTV2314

Brassica x hybridus "Saladeer"

Common Name: Saladeer hybrid Chinese cabbage

Tuvaluan Name: kapisi Saina (“Chinese cabbage”)

Status: Recent introduction. Asia.

Abundance: Occasional.

Remarks: Hybrid Chinese cabbage suitable for cultivation in warm climates. Food plant in houseyard food gardens; also planted in 2010 and 2016 in the Taiwan ICDF Garden from where it is sold to the public, restaurants and hotels on a weekly basis. Used in the same manner as Brassica chinensis.

Recorded: RRT 1991; RRT \& WAW 1993; RRT 2003; T, F \& F 2010; RRT 2016

Voucher Photographs: DPTV2128, 2266, 2399; DSC02608, 02616

Eruca sativa Mill.

Common Names: rocket, rocket lettuce, arugula

Status: Recent introduction. Mediterranean region.

Abundance: Rare.

Remarks: A couple of healthy mature plants seen in the Taiwan ICDF Garden in 2010. An expensive highly desired "lettuce" overseas.

Recorded: T, F \& F 2010

Voucher Photograph: DPTV2424

Rorippa sarmentosa (G. Forst. Ex DC.) Macbride

Synonyms: Cardamine sarmentosa Solander ex. Forst. f.; Nasturtium sarmentosum Schinz \& Guillaumin; Rorippa sarmentosum (DC.) Macbride 
Common Name: longrunner

Tuvaluan Names: lita (Ff); mouku (Seluka 1997); ātasi (Maiden 1904)

Status: Recent or aboriginal introduction? Solomon Islands and New Caledonia; possibly an aboriginal introduction to Fiji.

Abundance:

Remarks: Locally abundant weed in taro pits bordering the airport and rare in other moist locations. An important medicinal plant in Fiji, where it is known as rogomi, but no use reported for Tuvalu. Could have been an aboriginal or recent introduction along with taro culture. Reported present in 1898 by Maiden (1904).

Recorded: JHM 1904; RRT \& WAW 1993 (24153); SS 1997; RRT 2003; T, F \& F 2010

Voucher Photographs: DPTV3381, 3419, 3420, 3421

\section{CACTACEAE (CACTUS FAMILY)}

Hylocereus undatus (Haw.) Britt. and Rose

Common Names: night-blooming cereus, dragon fruit

Status: Recent introduction. Mexico.

Abundance: Rare.

Remarks: Large climbing, night-blooming cactus seen as an immature ornamental potplant in the 1991 and planted as fruit plant seedlings in the Taiwan ICDF Garden in 2010. White pulp of the red-pink "dragon fruit” is refreshing to eat and common in Southeast Asia.

Recorded: T, F \& F 2010

Voucher Photographs: DPTV2331, 2374, 2419, 2420

Opuntia sp.

Common Name: prickly-pear cactus

Status: Recent introduction. Tropical America.

Abundance: Uncommon.

Remarks: Ornamental pot plant at Government Buildings in 2003 and in a number of houseyard gardens in 2010 and 2016.

Recorded: RRT 2003; T, F \& F 2010; RRT 2016

Voucher Photographs: DPTV3330, 3767

\section{CAPPARIDACEAE OR CAPPARACEAE (CAPER FAMILY)}

Cleome rutidosperma DC.

Common Names: blue cleome, fringed spiderflower

Status: Recent introduction. Tropical Africa.

Abundance: Uncommon.

Remarks: Weed with blue flowers in waste places near pig-rearing area along north of the runway and in one houseyard garden in Vaiaku north of airport in 2010.

Recorded: T, F \& F 2010; RRT 2016

Voucher Photographs: DPTV2590, 2591, 2592, 2593, 2600, 2661, 2662

\section{Cleome viscosa L.}

Synonyms: Cleome icosandra L.; Polonisia icosandra (L.) W. \& A.; P. viscosa (L.) DC.

Common Name: yellow cleome

Status: Recent introduction. Tropical Asia or Old World Tropics.

Abundance: Occasional.

Remarks: Weed with yellow flowers in waste places near the Taiwan ICDF Garden in 2010. Leaves reportedly used medicinally as a blood coagulant to treat wounds. 
Recorded: T, F \& F 2010, RRT 2016

Voucher Photographs: DPTV2294, 2305

Crateva religiosa Forst. f.

Synonym: Crateva speciosa Volk.

Common Name: sacred garlic pear

Status: Recent introduction. Tropical Asia.

Abundance: Extirpated.

Remarks: Single mature fruit tree planted in the Agriculture Department nursery at Vaiaku in 1991. Not seen since. An important fruit tree in the Western Caroline Islands (Palau, Yap and Chuuk) in Micronesia.

Recorded: RRT 1991 (24324)

\section{CARicACeAe (PAPAYA FAMiLy)}

\section{Carica papaya L.}

Common Names: papaya, pawpaw

Tuvaluan Names: olesi (Ff, Nm; TvD); olesi Tuvalu, olesi pālagi (Ff)

Status: Recent introduction. Tropical America.

Abundance: Common.

Remarks: Planted fruit tree in houseyard gardens and occasionally naturalized in ruderal sites. Older varieties with smaller fruit are known as olesi Tuvalu and recently introduced large-fruited varieties as olesi pālagi ("foreign"). New cultivars planted for distribution and sale in the Taiwan Food garden. An important fruit tree, the ripe fruits of which are eaten and fed to pigs, dogs and other animals. Green fruit sometimes used as a meat or fish tenderizer. The long male flowers (pula oleti) are used in head garlands (fou).

Recorded: RRT 1991; RRT \& WAW 1993; SS 1997; RRT 2003; T, F \& F 2010; RRT 2016

Voucher Photographs: DPTV0902, 2191, 2346, 2405, 2663, 2664, 3493, 3702, 3703

\section{CASUARINACEAE (CASUARINA FAMILY)}

\section{Casuarina equisetifolia L.}

Synonym: Casuarina litorea L.

Common Names: casuarina, she oak, ironwood, beefwood

Tuvaluan Names: lakau Kilisimasi (“Christmas tree”); pulukamu (“blue gum”; Seluka 2010)

Status: Recent introduction. Indian Ocean to Polynesia and Micronesia.

Abundance: Occasional.

Remarks: Found in houseyard gardens, as a roadside tree and as planted windbreaks or hedges. A number of large trees are planted along the road on the west side of the airport south of the terminal near the Prime Minister's residence. The tree was introduced in pre-independence times as a windbreak and nitrogenfixing tree, which at the time was known in Kiribati as burukam and Tuvalu as pulukamu. Hard, heavy timber used to make cricket bats, pounders, boxes, tool handles, furniture and a range of other products.

Recorded: RRT 1991; RRT \& WAW 1993; SS 1997; RRT 2003; T, F \& F 2010; RRT 2016

Voucher Photographs: DPTV0643, 2289, 2290, 2387, 2388, 2759, 3517, 3553

\section{CLUSiaCEAe (MANGOSTEEN FAMILY)}

\section{Calophyllum inophyllum L.}

Common Names: Portia tree, Alexandrian laurel, beach mahogany, tomano (Hawaii)

Tuvaluan Names: fetau (Ff, Nm, Nt; Tvd); itai (Nui)

Status: Indigenous. Tropical Africa to Eastern Polynesia and Micronesia.

Abundance: Common. 
Remarks: Large hardwood tree in some houseyard gardens, in the Government Center and occasional along lagoonside forests on the main inhabited islets and on uninhabited outer reef islets (motu). Some large trees are found along lagoon coast on Tepuka Islet. Seedlings are occasionally found along the ocean coast of Fogafale Islet along the coral rubble rampart formed during Tropical Cyclone Bebe in 1972 and in accumulations of drift seedlings in other coastal sites. Reported present on all of Tuvalu's atolls and probably a part of the original inland forest and woodland on the larger atoll islets. According to Koch (1983), the name Nukufetau, which means island or village of Calophyllum inophyllum, was given by Tongans in ancient times because of the abundance of the tree. One of Tuvalu's most important timber trees. The strong durable wood is used for canoe hulls and other boat parts, paddles, bailers, tool handles, net handles, shovels, climbing sticks or ladders, bats, clubs, bows, pounders, dishes, mortars, plates, slitgongs and house poles. The beautiful fragrant white-and-yellow flowers are among the most commonly used flowers in garlands (fou) and for scenting special coconut oil (sinu fetau) sometimes by boiling the flowers in the oil or putting them together in the sun (lā) to make sinu fakalā.

Recorded: CH 1896; JHM 1904; RRT 1991; RRT \& WAW 1993; SS 1997; RRT 2003; T, F \& F 2010; RRT 2016

Voucher Photographs: DPTV0661, 0885, 0662, 0816, 0958, 2076, 1066b, 2285, 2286, 2287, 2288, 2587, 2689, 2751, 2790, 2791, 2891, 2892, 2893, 2897, 2898, 2913, 2914, 2957, 2975, 2979, 2982, 3070, 3277, 3278, 3279, 3325b, 3516a, 3609a, 3610a, 3611a, 3720b; DSC02586

\section{COMBRETACEAE (TERMINALIA FAMILY)}

Lumnitzera littorea (Jack) Voigt

Synonym: Lumnitzera coccinea Wight \& Arn.

Common Name: red-flowered black mangrove

Tuvaluan Names: sagale (Vt, Nt; Tvd); hagale (Nm); tokotū (Ff, Nl); tangali (Nui; Woodroffe 1991)

Status: Indigenous. Tropical Asia through Malesia into Micronesia and Polynesia to the Marshall Islands, Kiribati and Tonga and Tuvalu in Polynesia.

Abundance: Extirpated on Funafuti but still locally common on Vaitupu and some other atolls.

Remarks: A red-flowered mangrove with small dark gray-green rounded leaves. Normally found along swampy basins and intertidal lagoon flats. Although present in the past on Funāfiti and Nukulaelae, where it was reportedly known as tokotū, it has long since been brought to local extinction through overuse of its very useful wood and land clearance. It is still present on Vaitupu, Nanumaga, Nukufetau, Nui and Niutao, where it is a culturally important tree. Koch (2002) reports that on Niutao it is believed that the tree was introduced to the atoll by Sautia, a Samoan high chief (ali'i). He reports that the hard, elastic and rot-resistant wood is used on Niutao for many purposes including roof supports (kautokotoko), eave battens (talava) and thatching needles (atolau); canoe parts, such as the platform (kaupalepale), outriggers (kiato), net supports rests (naga kofe), and bonito rod rests (futie); the support pieces and frames (taetae tae sasave) of submerged nets (tata) and large bird nets (seu); fishing rods (kofe), large hooks (lou palu) for oilfish (Ruvettus); wooden clubs for beating and cleaning bundles of tanned coconut fiber (makakafa) before for making it into cordage (kafa); and spears (velo), stilts (kausaele), drumsticks (kauta), coconut graters and a range of other useful articles. The attractive red flowers are used in garlands (fou) and to scent coconut oil (sinu) and, on Niutao, woven into a head garland (kula) for the installation of the chief of the Fuatia Clan. The wood is also made into charcoal for slow roasting. Also on Niutao, women weave old, decaying, scented sagale wood into the garlands (fau) and burn dead wood in earthen ovens for smoking (fakaau) skirts (titi) to give them the desired fragrance (manogi); and men use pieces of the trunk as fuel when burning coral limestone (lase). Sagale is a tree that should be consciously protected, propagated and replanted as part of programs to rehabilitate the atolls.

Recorded: CDW 1991; SS 1997; RT, F \& F 2010

\section{Terminalia catappa L.}

Common Names: Indian almond, Malabar almond, tropical almond 
Tuvaluan Name: kunikuni (from Kiribati te kunikun; Ff, Nm)

Status: Aboriginal introduction? Tropical Asia and Australia to Western Polynesia and Micronesia, but probably an aboriginal or a post-European introduction to Tuvalu from Kiribati or elsewhere.

Abundance: Uncommon.

Remarks: Large tree present in the Government Centre in 2003, but cut down to build the new government building; one large tree seen near a pig rearing area near the Toli outer islander settlement on the inner part of the coral rubble rampart from the ocean coast in south Vaiaku in 2010 and 2016. Reported by Fitchett (1987) on Funāfuti and by Woodroffe (1991) on Vaitupu; also reported present on Nanumea and possibly other atolls. A very attractive, spreading shade tree in villages throughout the Pacific. Young growing tips used to treat sore throats and coughs in other areas of the Pacific; wood used for house posts, platforms and firewood. Almond-like seeds of ripe fruit eaten. Should be much more widely planted and protected as a useful tree with edible fruit.

Recorded: KF 1987; CDW 1991; RRT 1991; RRT \& WAW 1993; SS 1997; RRT 2003; T, F \& F 2010; RRT 2016

Voucher Photographs: DPTV0870, 0871, 2917, 3577, 3578, 3579, 3580

Terminalia samoensis Rech.

Synonyms: Terminalia litoralis sensu auct. non Seem.; Terminalia saffordii Merr.

Common Name: beach almond

Tuvaluan Names: talie (Ff, Nm, Nt ; Tvd); te ipe (Nui)

Status: Indigenous. Indonesia to Micronesia and Eastern Polynesia.

Abundance: Occasional.

Remarks: Small tree with small red, almond -like fruits seen in coastal littoral forest on the main islets and on uninhabited outer islets (motu), such as Fualopa and Tepuka Islets, and occasionally planted in houseyard gardens. Reported by Maiden on Funafuti in 1904, and reported present on all other atolls, except Nanumaga, Nukufetau and Niulakita. Wood reportedly used for various purposes including canoe masts, platforms and poles and carved into shovels, spoons and other implements. On Niutao, the red fruits, which give off a fragrance (manogi), are worn in garlands; and the bark, after soaking in water, is used medicinally to treat loss of appetite (Koch 2002). Used medicinally in Tuvalu and one of the most important medicinal plants in Kiribati and the Marshall Islands, which should be more widely planted as an ornamental and culturally useful tree and for coastal protection.

Recorded: JHM 1904; RRT 1991; RRT \& WAW 1993; SS 1997; RRT 2003; T, F \& F 2010

Voucher Photographs: DPTV0795, 0821, 1045, 1053, 1055, 2894, 2895, 2931, 2932, 3099, 3100, 3101, 3105, 3106, 3138, 3162, 3163, 3164, 3166, 3166, 3167, 3168, 3169, 3170, 3171, 3172, 3333, 3334, 3335, 3336

\section{CONVOLVULACEAE (MORNING-GLORY FAMILY)}

\section{Ipomoea aquatica Forsk.}

Synonyms: Ipomoea reptans Poir.; Convolvulus reptans L.; I. repens Roth

Common Names: water spinach, swamp cabbage, water convolvulus, cangcong

Status: Africa to tropical Asia and Australia.

Abundance: Occasional.

Remarks: Planted in PRAP experimental garden and in the Taiwan ICDF Garden in 2010 and 2016. Edible leaves cooked as a spinach. A potentially important vegetable crop that could be intercropped in taro pit gardens and planted houseyard vegetable gardens. Sold weekly to the public, hotels and restaurants.

Recorded: RRT 2003; T, F \& F 2010; RRT 2016

Voucher Photographs: DPTV2394, 2396, 2397, 2398, 3765, 3766; DSC02652, 2654

Ipomoea batatas (L.) Lam.

Common Names: sweet potato, kumara

Tuvaluan Names: kumala, pateta (Ff, Nm; TvD); pateta māgalo (Seluka 1993) 
Status: Recent introduction. Tropical America.

Abundance: Occasional.

Remarks: Food plant in houseyard gardens, promoted by Family Food gardening project and the Agricultural Department as a supplementary staple and pig food; also planted in the Tuvalu Agricultural Department nursery, Taiwan Farm and the EEC-funded Global Climate Change Alliance food garden plots in 2016. Leaves used as mulch and fed to pigs and some parts of the plant reportedly used medicinally by Seluka (1993). Important staple food crop on the larger islands of the Pacific, but does not grow as well on atolls.

Recorded: RRT 1991; RRT \& WAW 1993; SS 1997; RRT 2003; T, F \& F 2010; RRT 2016

Voucher Photographs: DPTV0935, 1151, 2187, 2421, 2428, 2660, 2680, 2681, 2729, 2858, 2861, 2926; DSC02483, 02491, 02614, 03055

Ipomoea macrantha R. \& S.

Synonyms: Convovulus tuba Schlect.; Ipomoea tuba (Schlecht.) G. Don; I. grandiflora sensu Koidz. non Lam.; I. glaberrima Boj. ex Bouton; I. alba sensu Taylor non L.; Calonyction tuba (Schlect.) Colla

Common Names: wild moon flower, night-blooming beach morning-glory

Tuvaluan Names: fue, fue kena, fue pula kena (Ff); fue, fue tolo (Nm)

Status: Indigenous. Pantropical.

Abundance: Common.

Remarks: Somewhat woody creeping or climbing vine with white, night-blooming morning-glory-like flowers. Found in coastal strand forest, inland forest and scrub on main and outer islets (motu), in neglected coconut plantations and in ruderal sites; occasionally found planted or protected in houseyard gardens. Reported present on all atolls, except Nanumaga and Nukufetau. Plants used as mulch and fertilizer in garden areas. Attractive white flowers used in garlands and as house decoration. Koch (2002) reports that pieces the length of the forearm are used in magic to cast spells. Reported by some people to be used medicinally. Flowers worn by women over the ear or in hair as a sei.

Recorded: CH 1896; JHM 1904; CDW 1991; RRT 1991; RRT \& WAW 1993; SS 1997; RRT 2003; T, F \& F 2010; RRT 2016

Voucher Photographs: DPTV0627, 0628, 2436, 2565, 2566, 2567, 2568, 3374b, 3388, 3656, 3657; DSC03312, 03313

Ipomoea pes-caprae (L.) Sweet

Common Names: beach morning-glory, goat-foot morning-glory

Tuvaluan Names: fue, fue piniki, fue pula piniki (“pink-flowered fue”; Ff, Nm)

Status: Indigenous. Pantropical.

Abundance: Occasional.

Remarks: Vigorous creeping vine in coastal vegetation on the coral rampart on the ocean coast of Fogafale Islet, Funafuti, along oceanside of the margins of mangroves to the north of the runway and occasionally along roadside, in ruderal sites and waste places on Fogafale Islet. Not seen on Tepuka or other outer islets and, although reported present on other atolls by informants, it was not reported present on any atoll apart from Funāfuti by Woodroffe (1991). Reported present on Funafuti in 1897 by Maiden (1904). Sand-binding plant of considerable importance for protecting beaches and coastal topsoil from erosion. Leaves used for mulching, compost and fed to pigs; flowers worn by women over the ear or in hair as a sei.

Recorded: JHM 1904; CDW 1991; RRT 1991; RRT \& WAW 1993; SS 1997; RRT 2003; T, F \& F 2010; RRT 2016

Voucher Photographs: DPTV0588, 0589, 0590, 0591a, 0591d, 0927b, 2101, 2198, 2575, 2576, 2625, , 2634a, 2635, 2636, 2637, 2638a, 2784, 3587a, 3635b, 3636b, 3637b, 3638b

\section{Ipomoea triloba L.}

Common Name: little bell

Tuvaluan Name: fue (general term for vines in the morning-glory family)

Status: Recent introduction. West Indies. 
Abundance: Uncommon.

Remarks: Prostrate herbaceous vine with lobed leaves and light pink to purplish funnel-form morning-glorylike flowers. Found in weedy vegetation on the east of the airstrip towards the new sports field in 2010, possibly introduced with soils and plants from Fiji, and seen again in the same location and near the northeast end of the airstrip in 2016.

Recorded: T, F \& F 2010; RRT 2016

Voucher Photographs: DPTV2541, 2542, 2543, 2544; DSC02427, 2432

\section{CUCURBITACEAE (MELON OR GOURD FAMILY)}

Benicasa hispida (Thunb.) Cogn.

Synonyms: Benicasa cerifera (Fisch.) Savi; Cucurbita hispida Thunb.; C cerifera Fisch.

Common Names: wax gourd, ash pumpkin, winter melon, white gourd, tung kwa

Status: Recent introduction. Java.

Abundance: Uncommon.

Remarks: Seen in the Taiwan ICDF Garden in 2010. Cooked melon served in Chinese restaurants in Funafuti.

Recorded: T, F \& F 2010

Citrullus lanatus (Thunb.) Matsum. and Nakai

Synonym: Citrullus vulgaris Schrad. ex Eckl. and Zeyh.

Common Name: watermelon

Tuvaluan Name: meleni (Ff, Nm; TvD)

Status: Recent introduction. South Africa.

Abundance: Occasional.

Remarks: Food plant in houseyard food gardens, in prison food garden and in the Taiwan ICDF Garden.

Recorded: RRT 1991, 2003; T, F \& F 2010; RRT 2016

Voucher Photographs: DPTV1032, 1149, 2256, 2330, 2429, 2866, 3539b, 3544

Cucumis melo L. variety

Common Name: sweet melon

Tuvaluan Name: meleni (Ff)?

Status: Recent introduction. China?

Abundance: Occasional.

Remarks: New food plant in the Taiwan ICDF Garden in 2010. Ripe fruit sold in some local stores.

Recorded: T, F \& F 2010; RRT 2016

Voucher Photographs: DPTV2298, 2327, 2404, 2683a, 2864, 2939, 3762

Cucumis melo L. var. cantalupensis Naud

Common Names: cantaloupe, rock melon

Tuvaluan Name: meleni (Ff, Nm; Tvd)

Status: Recent introduction. Southwest Asia to the Mediterranean.

Abundance: Uncommon.

Remarks: Food plant in houseyard gardens.

Recorded: RRT 1991, 2003

Voucher Photograph: DPTV0892

Cucumis melo L. var. conomon Makino

Common Names: Oriental pickling melon, ts'it kwa

Tuvaluan Name: kukampa? (Ff)

Status: Recent introduction. China.

Abundance: Occasional. 
Remarks: Food plant in houseyard food gardens and in the Taiwan ICDF Garden in 2010.

Recorded: RRT 1991; T, F \& F 2010

Cucumis sativus L.

Common Name: cucumber

Tuvaluan Name: kukama (Ff, Nm; TvD)

Status: Recent introduction. Northern India.

Abundance: Common.

Remarks: Food plant in houseyard food gardens.

Recorded: RRT 1991; RRT \& WAW 1993; SS 1997; RRT 2003; T, F \& F 2010; RRT 2016

Voucher Photographs: DPTV2343; DSC02634

Cucurbita cultivar

Common Name: squash

Tuvaluan Name: panikeni (Ff; Tvd)

Status: Recent introduction. Tropical America.

Abundance: Rare.

Remarks: Seen in the Taiwan ICDF Garden in 2010.

Recorded: T, F \& F 2010

Voucher Photographs: DPTV2371, 2372b

Cucurbita maxima Duch. variety

Common Name: zucchini squash

Status: Recent introduction. South America.

Abundance: Rare.

Remarks: Food plant in home garden.

Recorded: RRT 1991, 2003; T, F \& F 2010

Voucher Photograph: DPTV2371

Cucurbita moschata Duchesne ex Poir.

Synonym Cucurbita pepo L. var. moschata (Duchesne)

Common Name: pumpkin

Tuvaluan Names: panikeni (Ff; TvD); panikē (from Kiribati bangike; Nm)

Status: Recent introduction. Central or northern South America.

Abundance: Occasional to common.

Remarks: The pumpkins present in Tuvalu seem to be Cucurbita moschata rather than C. pepo, the species name normally given to pumpkins in the Pacific, although some could be hybrids of different Cucurbita species. Occasional. Food plant in houseyard gardens, often as an adventive in waste places and gardens; also planted in the Tuvalu Agricultural Department nursery and the EEC-funded Global Climate Change Alliance food garden plots in rural south and north Fogafale Islet. An important supplementary vegetable, with both the fruit (pumpkins) and young shoots and leaves cooked as vegetables; also fed to livestock. Leaves used for mulching; and fruit reportedly used as fishing bait (Seluka 1997).

Recorded: RRT 1991; RRT \& WAW 1993; SS 1997; RRT 2003; T, F \& F 2010; RRT 2016

Voucher Photographs: DPTV2109, 2105, 2110, 2280, 2734, 3785; DSC02478, 02638, 02641, 02642, 02644

Lagenaria siceraria L.

Common Name: bottle gourd

Status: Recent introduction. Tropical Africa.

Abundance: Occasional. 
Remarks: Food plant reported present by Seluka (1997) and widely planted in the Taiwan ICDF Garden in 2010 and 2016. Promoted as a cooked vegetable and sold weekly to the public, hotels and Chinese restaurants.

Recorded: SS 1997; T, F \& F 2010; RRT 2016

Voucher Photographs: DPTV2295, 2296, 2297, 2313e, 2372a, 2382, 2383, 2384, 2435; DSC02658

Luffa acutangula (L.) Roxb.

Synonym: Cucumis acutangulus L.

Common Name: angled loofah

Status: Recent introduction. India, Paleotropics.

Abundance: Rare.

Remarks: Plant in PRAP experimental nursery in the late 1990s and in the Taiwan ICDF Garden in 2010.

Recorded: RRT \& WAW 1993; SS 1997; RRT 2003; T, F \& F 2010

Luffa cylindrica (L.) Roem.

Common Names: smooth loofah, wild vegetable sponge, sponge gourd

Status: Recent introduction. Tropical Asia.

Abundance: Common.

Remarks: Food plant in the Taiwan ICDF Garden in 2010 and 2016 and sold to the public, hotels and restaurants. Cooked fruit eaten as a new vegetable and cooked in Chinese restaurants.

Recorded: T, F \& F 2010; RRT 2016

Voucher Photographs: DPTV2341, 2342, 2353, 2380, 2434; DSC02645, 2648

\section{Momordica charantia L.}

Common Names: bitter gourd, bitter melon, balsam pear

Status: Recent introduction. Paleotropics.

Abundance: Occasional.

Remarks: Found in dump site near north end of airfield and in the PRAP experimental garden in the early 1990s; and planted on a large scale in the Taiwan ICDF Garden in 2010. Not seen in 2016. Fruit promoted as a nutritious vegetable and served in Chinese restaurants.

Recorded: RRT \& WAW 1993 (24171); SS 1997; RRT 2003; T, F \& F 2010

Voucher Photographs: DPTV2299, 2300, 2301, 2302, 2303, 2313a, 2313c, 2381

\section{EUPHORBIACEAE (SPURGE FAMILY)}

Acalypha grandis Benth.

Synonym: Acalypha amentacea Roxb. var. grandis (Benth.) Fosb.

Common Name: acalypha

Tuvaluan Names: ogoogo (Ff; TvD); kalakalāpuhi (Nm); kalakalāpuki? (TvD); kakarapus (Nui; Woodroffe 1991)

Status: Indigenous. Malesia to Samoa, Kiribati and Tuvalu?

Abundance: Abundant.

Remarks: Dominant groundcover in scrub vegetation and in ruderal and disturbed sites in coconut plantations and roadsides; common along airfield and around taro pits and pig rearing areas. Reported present by Woodroffe (1991) on all atolls except Niulakita. Reported present on Funafuti as “ogogo” by Maiden (1904) but reportedly misidentified as Macaranga (Woodroffe 1991). Leaves fed to pigs and used to wrap food and for fertilizer, compost or mulching (kaiao) and part of the plant are used to make fishing lures, popguns and lancets (Seluka 1997).

Recorded: JHM 1904; RRT 1991; RRT \& WAW 1993 (24156); SS 1997; RRT 2003; T, F \& F 2010; RRT 2016

Voucher Photographs: DPTV0540, 0690, 0691, 0722, 0843, 0847, 2141, 2167, 2476, 2930, 3002, 3003, 3004, 3382, 3384, 3385, 3392, 3460, 3460, 3461, 3733 
Acalypha hispida Burm. f.

Common Names: cats's tail, chenille plant, red-hot poker

Tuvaluan Names: ogoogo palagi (Ff); suisui pusi (from Kiribati; Ff); ogoogo pula kula (Seluka 1997)

Status: Recent introduction. Indonesia.

Abundance: Uncommon.

Remarks: Planted ornamental with red cat-tail like hanging flowers. Flowers used in head garlands (fou), sometimes by braiding then. Leaves used medicinally and for mulching and fertilizer.

Recorded: RRT 1991; RRT \& WAW 1993; SS 1997; RRT 2003; T, F \& F 2010; RRT 2016

Voucher Photographs: DPTV0896, 0906, 2684, 2685, 2686, 3777

Acalypha wilkesiana Muell.-Arg. var. wilkesiana

Synonyms: Acalypha amentacea Roxb. ssp. wilkesiana (Muell.-Arg.) Fosb.

Common Names: Joseph's coat, copper leaf, beefsteak plant

Tuvaluan Names: ogoogo kula, lakau kula (Ff); kalakalāpuhi kula (Nm); ogoogo laukula (Seluka 1997)

Status: Recent introduction. Pacific Islands.

Abundance: Common.

Remarks: Planted ornamental and hedge plant with red to variegated red, white and green leaves. Wood reportedly used as clamps and clothes pins and to make fish traps; red leaves used in head, neck and waist garlands (fou, ula and titi) and for mulch and fertilizer.

Recorded: RRT 1991; RRT \& WAW 1993; SS 1997; RRT 2003; T, F \& F 2010; RRT 2016

Voucher Photographs: DPTV0893, 2674, 2678

Acalypha wilkesiana Roxb. f. circinata Muell.-Arg.

Synonyms: Acalypha amentacea Roxb. f. circinata (Muell.-Arg.) Fosb.; Acalypha hamiltoniana

Common Name: picottee acalypha

Status: Recent introduction. Pacific Islands.

Abundance: Occasional.

Remarks: Planted ornamental and hedge plant; not seen since 2003.

Recorded: RRT 2003

Chamaesyce atoto (Forst. f) Croizat

Synonyms: Euphorbia atoto Forst.f.; Euphorbia chamissonis (Kl. and Gke.) Boiss.

Common Name: beach spurge

Tuvaluan Names: mouku toto (Ff, Nm); eveeve (Nt; Koch 2002); pulutai (Seluka 1997)

Status: Indigenous. Tropical Pacific.

Abundance: Locally common.

Remarks: Woody herb with milky white sap. Found in coastal littoral vegetation on sand and limestone and occasionally in inland open sites on Fogafale Islet. Common on inner beaches and above and slightly inland in clearings above the wave-cut beach ridge on Tepuka Islet. Reported present on Nanumea and Funafuti by Woodroffe (1991) and on Niutao by Koch (2002). Important sand-binding species. Koch (2002) reports that, on Nui, stems and leaves are woven together as a head garland (fou) and upper arm ornaments, partly due to their cooling affect. The milky sap (toto) reportedly used by children to write on skin.

Recorded: CWD 1991; RRT 1991; RRT \& WAW 1993; SS 1997; RRT 2003; T, F \& F 2010; RRT 2016

Voucher Photographs: DPTV0789, 0790, 0805, 0837a, 0838, 0842a, 2478, 2479, 2480, 3023a, 3024, 3025, 3026, 3027, 3029, 3065, 3066, 3067a, 3067a

Chamaesyce hirta (L.) Millsp.

Synonyms: Euphorbia hirta L.; E. pilulifera L.

Common Names: garden spurge, asthma plant, hairy spurge, old blood

Tuvaluan Name: mouku toto (Ff, Nm)

Status: Recent introduction. Pantropical. 
Abundance: Abundant.

Remarks: Weed in waste places, roadsides, gardens and ruderal sites. Reddish leaves occasionally used to weave into casual informal garlands. Reported present on Vaitupu and Nukulaelae by Woodroffe (1991).

Recorded: CWD 1991; RRT 1991; RRT \& WAW 1993; RRT 2003; T, F \& F 2010; RRT 2016

Voucher Photographs: DPTV0633, 2045, 2153

Chamaesyce hypericifolia (L.) Millsp.

Synonyms: Chamaesyce glomerifera Millsp.; Euphorbia glomerifera (Millsp.) Wheeler

Common Name: graceful spurge

Tuvaluan Name: mouku toto (Ff, Nm)

Status: Recent introduction. Tropical America.

Abundance: Common.

Remarks: Garden, wasteplace and ruderal weed. Stems and leaves uncommonly used in informal garlands.

Recorded: RRT 1991; RRT \& WAW 1993; RRT 2003; T, F \& F 2010; RRT 2016

Voucher Photographs: DPTV2071, 2094, 2106, 2313c, 3649, 3650, 3651

Chamaesyce prostrata (Ait.) Small

Synonym: Euphorbia prostrata Ait.

Common Names: prostrate spurge, red caustic creeper

Status: Recent introduction. Tropical America.

Abundance: Common.

Remarks: Weed along paths, roadsides and in open waste places.

Recorded: RRT 1991; RRT \& WAW 1993; RRT 2003; T, F \& F 2010; RRT 2016

Voucher Photographs: DPTV0562, 2130

Chamaesyce thymifolia (L.) Millsp.

Synonyms: Euphorbia thymifolia L.; Euphorbia rubricunda Steud.

Common Name: thyme-leafed spurge

Tuvaluan Name: mouku (general term for grasses and small weeds; Seluka 1997)

Status: Recent introduction. India.

Abundance: Common and spreading.

Remarks: Small prostrate weed along roadsides and pathways, around buildings and ruderal sites. First reported present by Seluka (1997) with no precise location. First seen by current authors in 2003, but increasingly common in 2010 and 2016 and largely replacing C. prostrata.

Recorded: SS 1997; RRT 2003; T, F \& F 2010; RRT 2016

Voucher Photographs: DPTV0638, 2021, 2467, 2615, 2771, 3659, 3660, 3661

Cnidoscolus chayamansa McVaugh

Common Names: chaya, tree spinach

Tuvaluan Names: pele, bele (from Fijian bele; Ff, Nm); pele vao ("bush pele”; Vt); tiaia (Seluka 1997)

Status: Recent introduction. Mexico.

Abundance: Common.

Remarks: Tall shrubby food plant to about $2 \mathrm{~m}$ or higher with bright green lobed leaves. Planted in houseyard gardens. Introduced during PRAP in the early 2000s and seen in the PRAP experimental garden in 2003, but found in many gardens in 2010 and 2016 where it has partly replaced the earlier introduction, pele or bele (Abelmoschus manihot). Nutritious leafy green vegetable that should be cooked because it contains weak hydrocyanic acid. Leaves also feed to livestock and used to wrap food. One of the few recent introductions that has survived in the harsh atoll environment.

Recorded: SS 1997; RRT 2003; T, F \& F 2010; RRT 2016

Voucher Photographs: DPTV0685, 0938, 2132, 2133 
Codiaeum variegatum (L.) Bl.

Synonym: Croton variegatum L.

Common Name: croton

Tuvaluan Names: lautagitagi fou (Ff); lanu uke (Seluka 1997)

Status: Recent introduction. Malaysia to Melanesia.

Abundance: Common.

Remarks: Shrub with attractive yellow, red, green or whitish variegated leaves. Planted ornamental in houseyard gardens and occasionally planted as a hedge plant. Colorful leaves used in head garlands (fou), other body ornamentation and flower arrangements.

Recorded: RRT 1991; RRT \& WAW 1993; SS 1997; RRT 2003; T, F \& F 2010; RRT 2016

Voucher Photographs: DPTV0647, 2042, 2043, 2142, 2677, 3681; DSC02670

Euphorbia cyathophora Murr.

Synonyms: Eurphorbia heterophylla sensu auct. non L.; E. heterophylla L. var. cyathophora (Murr.) Griseb.; Poinsettia cyathophora (Murr.) Kl. \& Gke.

Common Names: Mexican fire plant, hypocrite plant, wild poinsettia, dwarf poinsettia

Status: Recent introduction. Tropical America.

Abundance: Common. Erect herb with bright-red upper leaf-like bracts. Weed of roadsides, waste places and ruderal places. Reported present on Vaitupu by Woodroffe (1991).

Recorded: RRT 1991; RRT \& WAW 1993; RRT 2003; T, F \& F 2010; RRT 2016

Voucher Photographs: DPTV0953, 2028, 2100a, 2100b, 2359, 2369, 3552

\section{Euphorbia heterophylla L.}

Synonyms: Euphorbia geniculata Ortega; Poinsettia heterophylla (L.) Klotzsch \& Garcke

Common Name: wild spurge

Status: Recent introduction. Texas, Mexico and the West Indies.

Abundance: Rare.

Remarks: Single plant seen in a Fogafale houseyard garden. Reported present from Vaitupu by Woodroffe (1991).

Recorded: RRT 2003; T, F \& F 2010

Euphorbia milii Desmoulins

Synonym: Euphorbia splendens Bojer ex. W.J. Hook.

Common Name: crown of thorns

Status: Recent introduction. Madagascar.

Abundance: Uncommon.

Remarks: Small shrub with thorny stems, milky sap and red to red-pink flower bracts. A number of plants planted in the flower boxes of the Vaiaku Lagi Hotel, Fogafale Islet in 2016.

Recorded: RRT 2016

Voucher Photographs: DSC03405

Euphorbia sp.

Common Name: cactus spurge

Status: Recent introduction. India.

Abundance: Rare.

Remarks: Cactus-like ornamental succulent with green four-angled stems, tiny leaves and small thorns. Planted ornamental and potplant in houseyard garden. Reported present by Seluka as Euphorbia pseudocactus, but possibly the more common Euphorbia lactea Haw. (mottled candlestick, mottled spurge, milkstripe euphorbia).

Recorded: SS 1997 
Jatropha integerrima Jacq.

Synonym: Jatropha hastata Jacq.

Common Name: rose-colored jatropha

Status: Recent introduction. Cuba.

Abundance: Uncommon.

Remarks: Attractive shrub or small tree, up to $4 \mathrm{~m}$ high, with palmately-divided leaves with lobes leaflets and attractive red-pink flowers. Planted ornamental in two household gardens in south and north Fogafale Islet, Funafuti seen first in 2016. An increasingly popular ornamental shrub throughout the Pacific since the late 1970s. Flowers used in garlands and flower arrangements.

Recorded: RRT 2016

Voucher Photographs: DSC03106, DSC03108

\section{Manihot esculenta Crantz}

Synonyms: Manihot utilissima Pohl; M. manihot (L.) Karst.; Jatropha manihot L.

Common Names: cassava, manioc, tapioca

Tuvaluan Name: tapioka (Ff, Nm)

Status: Recent introduction. Brazil or Tropical South America.

Abundance: Occasional.

Remarks: Food plant in houseyard gardens and successfully planted in the excavated taro pits on Fogafale Islet, Funafuti in 2010. Reportedly only grown to any extent on Vaitupu. New narrow-leaved varieties have been planted in the Agricultural Department nursery and in sustainable agriculture for climate change plots in 2016. The tubers are cooked as a staple food and the leaves sometimes cooked as a spinach. The tubers, leaves and waste are fed to pigs and the leaves used as mulch or compost. The most important staple root crop in Fiji and very important staple food crop in Tonga and other larger islands.

Recorded: RRT 1991; RRT \& WAW 1993; SS 1997; RRT 2003; T, F \& F 2010; RRT 2016

Voucher Photographs: DPTV0909,1153, 1154, 2144, 2182, 2844; DSC02599

Pedilanthus tithymaloides (L.) Poit.

Synonyms: Phyllanthus carinatus Spreng.; Euphorbia tithymaloides L.

Common Names: slipper flower, slipper spurge, zigzag plant, redbird cactus, ribbon cactus

Tuvaluan Name: lakau toto (Seluka 1997)

Status: Recent introduction. Caribbean.

Abundance: Common.

Remarks: Planted ornamental, pot plant and hedge plant with succulent green or variegated white and green leaves and small red slipper-like flowers.

Recorded: RRT 1991; RRT \& WAW 1993; SS 1997; RRT 2003; T, F \& F 2010; RRT 2016

Voucher Photographs: DPTV0874, 2057, 2136, 3538

Phyllanthus acidus (L.) Skeels

Common Name: Otahiti gooseberry

Status: Recent introduction. Madagascar and India.

Abundance: Rare.

Remarks: Planted and well-established fruit tree with small yellow-green fruits in two houseyard gardens in 2003. Not seen in 2010 and 2016, possibly lost in Tropical Cyclone Tomas in early 2010.

Recorded: RRT 1991; RRT \& WAW 1993; RRT 2003

Voucher Photographs: DPTV0537, 0538, 0539, 0947, 0959

Phyllanthus amarus Sch. \& Th.

Synonym: Phyllanthus niruri L. sensu auct. plur. non L.

Common Names: sleeping spurge, six-o’clock

Tuvaluan Name: mouku laupukupuku (Ff, Nm)

Status: Recent introduction. Tropical America (despite African type locality). 
Abundance: Abundant.

Remarks: Weed of gardens, roadsides, waste places, the airport and other ruderal sites; one of the most common weeds in Funafuti. Reported from all islands except Nanumaga and Nukufetau. No reported uses.

Recorded: CDW 1991; RRT 1991; RRT \& WAW 1993; SS 1997; RRT 2003; T, F \& F 2010; RRT 2016

Voucher Photographs: DPTV2090, 1178, 2159, 2577, 3541a

Phyllanthus debilis Klein ex Willd.

Synonym: Phyllanthus niruri L. var. debilis Klein ex Willd.

Common Name: spurge

Status: Recent introduction. India or Sri Lanka.

Abundance: Rare.

Remarks: Weed seen along road near the end of the road at the south end of Fogafale Islet.

Recorded: RRT 2003

Voucher Photographs: DPTV0606

\section{Phyllanthus urinaria L.}

Common Name: spurge

Status: Recent introduction. Tropical East Asia.

Abundance: Rare.

Remarks: Rare weed with reddish stems seen near new Vaiaku Lagi Hotel.

Recorded: RRT 2003

\section{Ricinus communis L.}

Common Names: castor bean, castor oil plant

Status: Recent introduction. Africa.

Abundance: Rare.

Remarks: Shrub seen growing in a single population in a sewage sump seaside of Tuvalu Government Building just to the south of the hotel. Possibly introduced with landscaping for the building, which was opened in 2004. Potentially an invasive weed that is invasive in Fiji and Tonga. Not seen in the area in 2016.

Recorded: T, F \& F 2010

Voucher Photographs: DPTV2064, 2073, 3353

Sauropus androgynus Merr.

Common Name: Borneo cabbage

Status: Recent introduction. Southern Asia to Malesia.

Abundance: Rare.

Remarks: Plant in PRAP experimental garden in 2003. Leaves are cooked as a nutritious edible spinach. Recorded: RRT 2003

\section{FABACEAe OR Leguminosae (BeAN, PeA OR Legume FAMily)}

Acacia farnesiana (L.) Willd.

Synonym: Mimosa farnesiana L.

Common Names: sweet acacia, West Indian blackhorn, cassie flower

Tuvaluan Name: kaipakoa (from the Kiribati te kai bakoa, "shark tree,” possibly because of the sharp thorns that resemble shark's teeth)

Status: Recent introduction. Tropical America.

Abundance: Extirpated?

Remarks: Seen in past in houseyard gardens on Funafuti in 1991 and reported from some other atolls. Reported present by Seluka (1997), but not seen since 1991 by current authors. Large shrub with thorns 
and fragrant yellow flowers that are used in head garlands (fou). Possibly introduced from Kiribati, Banaba or Nauru where it was common in the early 1980s (Thaman et al. 1994).

Recorded: RRT 1991; SS 1997

\section{Adenanthera pavonina L.}

Common Names: red-bead tree, false sandlewood

Tuvaluan Names: lopaa, lop $\bar{a}$ (from Samoan lop $\bar{a}$ )

Status: Recent introduction? Malaysia.

Abundance: Rare or extirpated.

Status: Two trees seen in houseyard gardens, one mature and one well established but not bearing in 1991.

Possibly introduced from Samoa where the bright-red seeds are an important snack food or from Nauru here is abundant and invasive (Thaman et al. 1994, 2008). Not seen since 1991.

Recorded: RRT 1991

Alysicarpus vaginalis (L.) DC.

Synonyms: Hedysarum vaginale L; Alysicarpus nummularifolius (L.) DC.

Common Names: alysicarpus, one-leaved clover

Status: Recent introduction. Paleotropics.

Abundance: Occasional.

Remarks: Creeping weed with reddish flowers along east side of airport runway, in wasteplaces and in other ruderal and grassy sites.

Recorded: RRT 1991; RRT \& WAW 1993 (24152); RRT 2003; T, F \& F 2010; RRT 2016

Voucher Photographs: DPTV0914, 2726

\section{Bauhinia sp.}

Common Names: bauhinia, orchid tree

Status: Recent introduction.

Abundance: Rare.

Status: Non-flowering mature trees seen in two houseyard gardens north of Vaiaku and one in garden south of airport 2010.

Recorded: T, F \& F 2010

Voucher Photographs: DPTV0996, 2667, 2668, 2669

Caesalpinia bonduc (L.) Roxb.

Common Names: beach nicker, gray nicker, nicker bean

Tuvaluan Name: talatalāmoa? (Tvd)

Status: Indigenous. Pantropical.

Abundance: Extirpated or ephemeral.

Remarks: Reported only from seeds collected on the shore of Funafuti in 1898 and identified by Maiden (1904). An occasional plant in coastal areas throughout the Pacific, which has probably been present at various times throughout history on Funafuti and on other islands in Tuvalu. The name talatalāmoa or a cognate is the name for the plant in Tonga and other areas in Polynesia. A serious noxious weed with sharp thorns in Nauru that should be eradicated if possible from settled areas where it exists. Beautiful grey seeds used to make expensive necklaces in Hawai'i.

Recorded: JHM 1904

Caesalpinia pulcherrima (L.) Swartz

Common Name: pride of Barbados, dwarf poinciana, Barbados flower fence

Status: Recent introduction. Tropical America.

Abundance: Rare. 
Remarks: Shrub with thorny stems, compound leaves and very attractive bright red-orange to yellow flowers with yellow margin and long red stamens. Planted ornamental shrub in a single houseyard garden on Fogafale Islet in 2016.

Recorded: RRT 2016

Voucher Photographs: DSC03207, DSC03208

Cajanus scarabaeoides (L.) Thouars.

Synonym: Atylosia scarabaeoides (L.) Benth.

Common Name: peanut grass

Status: Recent introduction. Wide spread from Asia to Australia.

Abundance: Rare.

Remarks: Climbing trifoliate herb with pubescent reddish stems. Seen only along the road south of the airport in 2003, possibly introduced from Fiji where it is well-established as a pasture legume (Thaman and Keppel 2003).

Recorded: RRT 2003

Voucher Photograph: DPTV0554

\section{Canavalia cathartica Thou.}

Synonyms: Canavalia microcarpa (DC.) Piper; C. turgida Graham (of Burges list)

Common Name: Mauna Loa bean (Hawaii)

Tuvaluan Name: saketa (Ff, Nm; Tvd)

Status: Indigenous. Pantropical.

Abundance: Common.

Remarks: Climbing vine with compound leaves three leaflets and pink pea-like flowers. Vine climbing on trees in neglected coconut plantations and in lagoon coast vegetation. Common in the interior and in coastal vegetation of Tepuka and other uninhabited islets of Funafuti. Reported present from all atolls except Niutao and Niulakita. Probably mistakenly reported present as Canavalia rosea by Seluka, which has not been reported present on any of the atolls. Leaves used as compost and leaves and other parts of the plant used medicinally.

Recorded: JHM 1904; CDW 1991; RRT 1991; RRT \& WAW 1993 (24170); SS 1997; RRT 2003; T, F \& F 2010; RRT 2016.

Voucher Photographs: DPTV0549, 0550, 0711, 0728, 0732, 0800, 0802, 1047a, 1048, 1123, 2989, 2990, 2991, 2992, 2997, 2998, 2999, 3000, 3001, 3046, 3054, 3055, 3056, 3057, 3209, 3214, 3250, 3253, 3254

\section{Clitorea ternatea L.}

Common Name: butterfly pea

Status: Recent introduction. Tropical America or Pantropical.

Abundance: Uncommon.

Remarks: Planted ornamental vine-like plant with rich blue butterfly- or pea-like flowers.

Recorded: RRT 1991, 2003

\section{Crotalaria pallida L.}

Synonym: Crotalaria. mucronata Desv.

Common Name: rattlepod

Status: Recent introduction. Old World Tropics.

Abundance: Uncommon.

Remarks: Plant with trifoliate leaves and spikes of yellow pea-like flowers. One population seen near the new sports complex, one along a roadside and in one houseyard garden in 2010 and again in 2016.

Recorded: T, F \& F 2010; RRT 2016

Voucher Photograph: DPFF2109 
Delonix regia (Bojer) Raf.

Common Name: poinciana, royal poinciana, flame tree, flamboyant

Tuvaluan Names: fuatausaga ("flowering at the beginning of the new year"; Ff); fuatauhaga (Nm)

Status: Recent introduction. Madagascar.

Abundance: Uncommon.

Remarks: Planted ornamental tree with bright red-orange and white flowers. Seedlings planted in the Agricultural Department nursery in 2016. Flowers, usually only the petals, are used in head and neck garlands (fou and ula) and flower arrangements. Tree shows good adaptability to the harsh atoll conditions.

Recorded: RRT 1991; RRT \& WAW 1993; RRT 2003; T, F \& F 2010; RRT 2016

Voucher Photographs: DPTV0649; DSC02584, 2585

Desmodium heterophyllum (Willd.) DC.

Common Name: tropical trefoil

Status: Recent introduction. Southeastern Asia to Malesia, and perhaps the Mariana Islands in Micronesia. Now naturalized on many Pacific Islands.

Abundance: Common.

Remarks: Clover-like creeping plant found in the front lawn of the new Tuvalu Government Building in 2010 and now widespread in lawn, roadsides and ruderal sites.

Recorded: T, F \& F 2010; RRT 2016

Voucher Photographs: DPTV2065, 2066, 2074, 3478, 3479, 3480, 3530

Desmodium incanum DC.

Synonym: Desmodium canum (Gmel.) Sch. \& Th.

Common Name: Spanish clover

Status: Recent introduction. West Indies.

Abundance: Occasional.

Remarks: Small herbaceous shrub with trifoliate leaves with greyish blotches along the midribs. Found along the airfield, in ruderal sites and climbing in inner coastal vegetation on Fogafale Islet.

Recorded: RRT 1991 (24309, 24310, 24316); RRT \& WAW 1993 (24177); RRT 2003; T, F \& F 2010; RRT 2016

Voucher Photographs: DPTV0654, 1012, 1140, 2364, 2368, 3367, 3369

Leucaena leucocephala (Lam.) de Wit

Synonym: Leucaena glauca (L. ex Willd.) Benth

Common Names: leucaena, koa haole (Hawaii), lead tree, wild tamarind

Tuvaluan Name: lakau fai fuaga ("plant with seeds"; Ff)

Status: Recent introduction. Tropical America.

Abundance: Locally common.

Remarks: Erect shrub with white flowers and brown seed pods and shiny dark brown seeds. Seen in houseyard gardens, sometimes as part of living fencing and occasional in ruderal sites and inner coastal vegetation, apparently naturalized in some sites on south Fogafale Islet. Introduced as a nitrogen-fixing tree. Leaves used as mulch and stems as firewood. Seeds sometimes strung into necklaces or leis (ula), often along with small shells (misa).

Recorded: RRT 1991; RRT \& WAW 1993; SS 1997; RRT 2003; T, F \& F 2010; RRT 2016

Voucher Photographs: DPTV0623, 0624, 1162, 2558, 2562, 3642

Macroptilium atropurpureum (DC.) Urb.

Synonym: Phaseolus atropurpureus DC.

Common Names: siratro, purple bushbean, phasely bean

Status: Recent introduction. Tropical America.

Abundance: Uncommon. 
Remarks: Weed with dark blackish- maroon flowers in waste areas to the east of the runway near the new Tuvalu Sports Complex. Possibly a recent introduction from Fiji with soil for new sports ground. Nitrogen-fixing plant.

Recorded: T, F \& F 2010

Voucher Photographs: DPTV2545, 2546

Macroptilium lathyroides (L.) Urb.

Synonyms: Phaseolus lathyroides L.; P. semierectus L.

Common Name: Phasey bean

Status: Recent introduction. Tropical America.

Abundance: Uncommon.

Remarks: Weed with dark maroon flowers in waste areas to the east of the runway near the new sports ground. Possibly a recent introduction from Fiji with soil for new Tuvalu Sports Complex.

Recorded: T, F \& F 2010

Voucher Photographs: DPTV2547, 2548, 2549

\section{Mimosa pudica L.}

Common Name: sensitive plant

Tuvaluan Names: mouku matiotio (Ff); kaimatuu (Seluka 1997)

Status: Recent introduction. Tropical America.

Abundance: Occasional.

Remarks: Creeping herbaceous subshrub with prickly stems, pink flowerheads and leaves that fold up when touched. Originally reported from Funafuti and Niutao (Woodroffe 1991). Common in 2010 around the new Tuvalu Government Building and in areas along the airstrip and around the new Tuvalu Sports Complex. Can becomes a bothersome weed because of its prickles.

Recorded: CDW 1991; SS 1997; T, F \& F 2010; RRT 2016

Voucher Photograph: DPTV2499

Mucuna gigantea (Willd.) DC.

Common Names: seabean, giant seabean, velvet bean

Tuvaluan Name: saketa

Status: Indigenous. Africa and Indian Ocean islands to India and China and eastward in the Pacific to the Society Islands and Hawai'i.

Abundance: Rare.

Remarks: High-climbing vine with yellow flowers. Found localized on the southern end of Fogafale Islet climbing in coastal forest along the road and along an inland path in 1993.

Recorded: RRT \& WAW 1993 (24175)

\section{Phaseolus vulgaris L.}

Common Names: string bean, French bean, haricot bean

Tuvaluan Names: piini, pini (Tvd; Seluka 1997)

Status: Recent introduction. Tropical America.

Abundance: Uncommon.

Remarks: Probably seasonally planted from imported seed. Food plant occasionally planted in houseyard gardens and in experimental farms.

Recorded: SS 1997

Samanea saman (Jacq.) Merr.

Synonyms: Albizia saman (Jacq.) F. v. Muell.; Mimosa saman Jacq.; Enterolobium saman (Jacq.) Prain ex

King; Pithecellobium saman (Jacq.) Benth.; Inga saman (Jacq.) Willd.

Common Names: rain tree, monkeypod tree

Status: Recent introduction. Tropical America. 
Abundance: Rare.

Remarks: Single planted ornamental tree in houseyard garden just south of the Government center.

Recorded: RRT 2003

Senna occidentalis (L.) Link

Synonym: Cassia occidentalis L.

Common Names: coffee senna, arsenic bean

Status: Recent introduction. Tropical America.

Abundance: Occasional.

Remarks: Shrub with yellow flowers and slender pods. Weed of waste places, roadsides, and flower gardens. Seen in a wasteplace near the new sports ground in 2010.

Recorded: RRT 1991 (24303, 24312); RRT 2003; T, F \& F 2010; RRT 2016

Voucher Photographs: DPTV0890, 0891, 0997, 2552, 2553, 2554, 2555, 2556, 2557, 2825

Senna tora (L.) Roxb.

Synonym: Cassia tora L.

Common Name: peanut weed

Status: Recent introduction. Tropical America, now pantropical.

Abundance: Uncommon.

Remarks: One plant about $80 \mathrm{~cm}$ high seen along road south of the airstrip in 2003 and a couple of plants in seen in a disturbed site near the TANGO headquarters in 2010.

Recorded: RRT 2003; T, F \& F 2010

Voucher Photographs: DPTV0551, 0552, 2461, 2462

Sesbania cannabina (Retz.) Pers.

Common Names: prickly sesban, sesbania pea, canicha

Status: Recent introduction. India and Asiatic tropics.

Abundance: Occasional.

Remarks: Healthy and spreading populations in grassy areas to the east of the runway near the TANGO headquarters and near the new sports complex in 2010. A potentially aggressive shrubby weed with small white flowers that was reportedly introduced with soil from Fiji during the construction of the new Tuvalu Sports Complex. Seen again in 2016. Should be eradicated immediately as it is spreading out of control in places along roadsides near Suva, Fiji.

Recorded: T, F \& F 2009; RRT 2016

Voucher Photographs: DPTV2450, 2451, 2452, 2453, 2454, 2455, 2533, 2571, 2572

Sesbania grandiflora (L.) Pers.

Synonym: Robinia grandiflora L.

Common Names: sesban, sesbania

Tuvaluan Name: sesipania (Seluka 1997)

Status: Recent introduction. Indo-Malesia, but now widely cultivated.

Abundance: Rare or extirpated.

Remarks: A weak-stemmed, soft-wooded tree with grey-green leaves and beautiful rich-red butterfly-like flowers. A number of trees planted in PRAP trials of nitrogen-fixing trees in the 1990s. A nitrogenfixing and multipurpose tree with edible leaves, young pods and flowers, trialled in Tonga, Samoa, Kiribati and Tuvalu.

Recorded: SS 1997

\section{Sophora tomentosa L.}

Common Name: silverbush

Status: Indigenous. Indian Ocean to eastern Polynesia and Micronesia.

Abundance: Rare to uncommon. 
Remarks: Seen in 2003 as a single individual in the coastal strand vegetation in the outpost zone on the northwest end of Tepuka Islet and again on Tepuka in 2010 as an apparently planted population about $10 \mathrm{~m}$ inland from the coast in a clearing near Calophyllum inophyllum trees. Probably an oceandispersed ephemeral species that comes and goes. Deliberately introduced to Tarawa from Onotoa Atoll as an indigenous nitrogen-fixing species in Kiribati in the 1990s.

Recorded: RRT 2003, T, F \& F 2010

Voucher Photographs: DPTV0776, 0777, 3273, 3274

Tamarindus indicus L.

Common Name: tamarind

Tuvaluan Name: tamalini (Seluka 1997)

Status: Recent introduction. Tropical Asia.

Abundance: Rare or extirpated. Single tree, over $4 \mathrm{~m}$ high, seen at PRAP experimental nursery and another in the Agricultural Department nursery in Vaiaku in 1990s and early 2000s. Not seen since.

Recorded: RRT 1991 (24328); RRT \& WAW 1993; SS 1997; RRT 2003

Voucher Photographs: DPTV1025, 1026

Vigna marina (Burm.) Merr.

Synonyms: Vigna lutea (Sw.) A. Gray; Phaseolus marinus Burm.; Dolichos luteus Sw.

Common Name: beach pea

Tuvaluan Names: saketa (Ff, Nm; Tvd); saketa sama (“yellow”; Seluka 1997)

Status: Indigenous. Pantropical.

Abundance: Abundant.

Remarks: Vine with yellow flowers found creeping and climbing over low vegetation on beaches, in coastal forest on both ocean and lagoon coasts and in waste places and ruderal sites; found as pioneer species on coral rubble rampart formed by Tropical Cyclone Bebe in 1972. Also growing in from the margins on the newly reclaimed borrow pits in both north and south Fogafale Islet in 2016. Reported from all atolls except Nanumaga, Niutao and Nukufetau. Found spreading over the margins of the recently reclaimed areas north of the rubbish dump in 2016. A nitrogen-fixing plant, used as compost and pig feed; and reportedly used medicinally in some islands and is a very important medicinal plant in Tonga and other areas of Polynesia.

Recorded: CDW 1991; RRT 1991; RRT \& WAW 1993; SS 1997; RRT 2003; T, F \& F 2010; RRT 2016

Voucher Photographs: DPTV0597, 0598, 0600b, 0773, 0786, 1085, 1163, 2112, 2485, 2976b, 3582, 3634, 3635a, 3636a, 3637a, 3638a; DSC03231

Vigna sesquipedalis (L.) Fruw.

Synonyms: Dolichos sesquipedalis L.; Vigna unguiculata (L.) Walp. ssp. sesquipedalis (L.) Verdc. Vigna sinensis (L.) Endl. ex Hassk. var. sesquipedalis (L.) Koern.

Common Names: long bean, yard-long bean, snake bean, asparagus bean

Tuvaluan Names: piini, pīni (Ff, Nm ; Tvd)

Status: Recent introduction. Tropical Africa.

Abundance: Occasional.

Remarks: Food plant in houseyard food gardens and in the Taiwan ICDF Garden in both 2010 and 2016.

Beans sold to the public, hotels and restaurants and cooked and served in Chinese restaurants on Funafuti.

Recorded: RRT 1991; RRT \& WAW 1993; SS 1997; RRT 2003; T, F \& F 2010; RRT 2016

Voucher Photographs: DPTV2311, 2312, 2323, 2329, 2437, 2438, 2439, 2443, 2683b; DSC02651

Vigna unguiculata (L.) Walp.

Synonyms: Vigna sinensis L.; Vigna unguiculata (L.) Walp. ssp. unguiculata

Common Name: cowpea

Status: Recent introduction. Tropical Africa and an early introduction to South Asia. 
Abundance: Uncommon.

Remarks: Food plant in the Taiwan ICDF farm in 2016. Beans sold to the public, hotels and restaurants and cooked and served in Chinese restaurants on Funafuti. One of the most important pulse and legume food crops throughout the semi-arid tropics.

Recorded: RRT 2016

Voucher Photograph: DSC02655

\section{GESNERIACEAE (GLOXINIA FAMILY)}

Chrysothemis pulchella (Donn ex Simms) Decaisne

Common Name: dozakie

Status: Recent introduction. Central America.

Abundance: Uncommon.

Remarks: Herbaceous plants with orange and red flowers. Seen in the Vaiaku Lagi Hotel garden, at the Blue Ocean bar and in one other houseyard garden. Distributed by the Taiwan ICDF Garden program.

Recorded: RRT 2003; T, F \& F 2010

Voucher Photographs: DPTV1009, 2813, 2923

\section{GOODENIACEAE (NAUPAKA FAMILY)}

Scaevola taccada (Gaertn.) Roxb.

Synonym: Scaevola sericea Vahl.

Common Names: half-flower, beach saltbush

Tuvaluan Names: gasu (Ff, Nt; TvD); gahu (Nm, Nui; TvD)

Status: Indigenous. Tropical Asia to Hawaii.

Abundance: Very abundant.

Remarks: Abundant in strand vegetation on both ocean and lagoon coasts and in inland vegetation on uninhabited islets and in coconut plantations and secondary vegetation; occasional in waste places and planted or protected along roads; a main pioneer species in the recolonization of the coral rubble rampart formed by Tropical Cyclone Bebe in 1972. Wood used for smaller house parts, household tools and furnishings, such as small tables or cooking stands, fish clubs and scoop net handles for fishing, and sometimes for canoe parts; leaves used for body ornamentation and, in the past, in small bundles to be worn in pierced ear lobes; leaves also used as part of sunshades (mataili) to protect eyes; leaves also used as compost (kaiao) in taro pits (pela); white flowers used in head garlands (fou) and to scent coconut oil (sinu); parts also used medicinally (Seluka 1997; Koch 2002).

Recorded: CH 1896; JHM 1904; CDW 1991; RRT 1991; RRT \& WAW 1993; RRT 2003; T, F \& F 2010; RRT 2016

Voucher Photographs: DPTV0585, 0586, 0587, 0591b, 2034, 0591b, 0712, 0770b, 0771a, 0782, 0783, 0784, 0785, 0787a, 0834b, 1017a, 1018a, 1021a, 1044, 1047b, 1086b, 2482, 2483, 2484, 2643a, 2785a, 2788b, 2796, 2797, 2976a, 3008, 3009, 3010, 3016, 3030, 3032, 3040b, 3041b, 3042c, 3048, 3058, 3059, 3076, 3263a, 3276, 3302b, 3303b, 3311a, 3312a, 3313a, 3314a, 3315a, 3316a, 3317a, 3586a, 3587b, 3589a, 3626b, 3632, 3633

\section{HERNANDIACEAE (HERNANDIA FAMILY)}

Hernandia nymphaeifolia (Presl.) Kubitzki

Synonyms: Hernandia sonora L.; H. peltata Meissn.; H. ovigera senus auct. non L.; Biasolettia nymphaeifolia Presl

Common Names: hernandia, lantern tree

Tuvaluan Names: puka (Ff, Nm, Nt, Nui; Tvd); puka vaka (Ff, Nt); puka vai, puka faivaka (Nm)

Status: Indigenous. Tropical Asia to Pacific Islands.

Abundance: Occasional. 
Remarks: Planted or protected in houseyard gardens and occasional in degraded inland coconut plantations and lagoon coast vegetation. On some of the other atolls in Tuvalu it is also found in stands on uninhabited islands, often in association with the more dominant puka vai (Pisonia grandis). Important nesting tree for some seabirds. The relatively light timber of the main trunk is favored for canoe hulls, and the timber for bow and stern covers, outrigger floats and other canoe parts and bailers and floats. Also used in construction, for flooring, for making coffins and a range of other purposes. In the past, larger travelling rafts (lualua) were made from puka logs. Wood also used for long bird net handles, for firewood and to burn coral lime (lase). Leaves used medicinally on Niutao to treat infection in pierced ears and as compost (kaiao) in taro pits (pela). Dark-brown seeds used to make necklaces (ula) and handcrafts, commonly together with small shells (misa). In the past the seeds were made into charcoal that was used as a pigment for tattooing (Maiden 1904; Koch 2002).

Recorded: CH 1896; JHM 1904; CDW 1991; RRT 1991; RRT \& WAW 1993; RRT 2003; T, F \& F 2010; RRT 2016

Voucher Photographs: DPTV0635, 0792, 1066a, 2209, 2210, 2460, 2753, 2754, 3749, 3750, 3751, 3752, 3786, 3787, 3788

\section{LAMIACEAE (MINT FAMILY)}

\section{Mentha piperita L.}

Synonym: Mentha x piperita L. (M. aquatica L. x M. spicata L.)

Common Names: mint, peppermint

Tuvaluan Name: miniti? (Seluka 1997)

Status: Recent introduction. Europe.

Abundance: Rare.

Remarks: Pot herb planted in containers; seen in three gardens over the past twenty years.

Recorded: RRT 1991; RRT \& WAW 1993; SS 1997; RRT 2003; T, F \& F 2010

\section{Ocimum basilicum L.}

Common Names: basil, sweet basil

Tuvaluan Name: mili kai (Ff, Nm)

Status: Recent introduction. Africa to the Pacific Islands (Paleotropics).

Abundance: Uncommon.

Remarks: Pot plant in two houseyard gardens. Planted in the Taiwan ICDF Garden in 2010. Leaves used in as a spice in cooking and in garlands and to scent coconut oil.

Recorded: RRT 2003; T, F \& F 2010

Voucher Photographs: DPTV2350, 2446, 2855, 2860, 3770

\section{Ocimum tenuiflorum L.}

Synonym: Ocimum sanctum L.

Common Names: sacred basil, holy basil, tulsi (Hindi)

Tuvaluan Name: mili manogi (Ff, Nm)

Status: Recent introduction. Tropical Asia, now Pantropical.

Abundance: Occasional.

Remarks: Planted ornamental and cultural plant in houseyard gardens. Fragrant flowers and leaves used in garlands and headbands (fou) and for scenting coconut oil.

Recorded: RRT 1991; RRT \& WAW 1993; RRT 2003; T, F \& F 2010; RRT 2016

Voucher Photograph: DPTV3331

Plectranthus amboinicus (Lour.) Spreng.

Synonyms: Coleus amboinicus Lour.; Coleus aromaticus Benth.

Common Names: Indian borage, Spanish thyme, Mexican oregano

Status: Recent introduction. Africa and India to Indonesia. 
Abundance: Rare.

Remarks: Pot herb with succulent, pubescent aromatic leaves in hospital matron's garden. Leaves used as a spice and for scenting coconut oil and laundry in places where it is common.

Recorded: RRT 1991; RRT \& WAW 1993; RRT 2003; T, F \& F 2010

Plectranthus scutellarioides (L.) R. Br.

Synonyms: Coleus scutellarioides (L.) Benth.; Coleus blumei Benth.; Solenostemon scutellaroides (L.) Gould

Common Names: painted nettle, variegated coleus

Tuvaluan Name: mili (Ff)

Status: Recent introduction. Malaysia.

Abundance: Uncommon.

Remarks: Ornamental pot plant with variegated, variously colored green, purple, red, white or all four-color leaves.

Recorded: RRT 1991; RRT \& WAW 1993; SS 1997; RRT 2003; T, F \& F 2010

\section{LAURACEAE (LAUREL FAMILY)}

\section{Cassytha filiformis L.}

Common Names: beach dodder, giant dodder, devil's twine

Tuvaluan Name: fetai (Ff, Nm, Nt; Tvd)

Status: Indigenous. Pantropical.

Abundance: Abundant.

Remarks: Leafless, yellow-green to yellow-orange parasitic vine. Found climbing on other plants, generally on shrubs and herbs, but also on trees, or creeping on its own in lagoon and oceanside coasts and on rocky limestone soils in scrubland. Common on uninhabited islets, such as Tepuka Islet, in coastal outpost vegetation. Reported present from all atolls in Tuvalu. Leafless stems worn as body ornamentation (napenape), often interwoven into impromptu head or neck garlands (fou and ula) or arm bands, often while on picnics or going to the bush. It is common for someone walking along the beach, around an islet or on a picnic to return with a fou fetai. Used to freshen up black clothes, mixed with water to bath babies, and used in traditional magic related to the collection of toddy on Niutao (Koch 2002). Plant also used as mulch, in medicines and to make a woman's hair long.

Recorded: JHM 1904; CDW 1991; RRT 1991; RRT \& WAW 1993; SS 1997; RRT 2003; T, F \& F 2010; RRT 2016

Voucher Photographs: DPTV0609, 0769, 0770a, 0775, 0837b, 0842b, 2473, 2489, 2490, 2538, 3019, 3020, 3042b, 3043, 3044, 3045

\section{Persea americana Mill.}

Synonyms: Laurus persea L.; Persea gratissima Gaertn. f.

Common Names: avocado, avocado pear, alligator pear

Status: Recent introduction. Mexico.

Abundance: Rare.

Remarks: Single immature plant in Bank garden in 2003. Not seen since.

Recorded: RRT 2003

\section{LYTHRACEAE (LOOSESTRIFE FAMILY)}

Pemphis acidula J.R. \& G. Forst

Common Names: pemphis, ironwood

Tuvaluan Names: gie (Ff, Nm; TvD); giegie (Nt; TvD; Koch 2002)

Status: Indigenous. Tropical East Africa to Southeast Polynesia and Micronesia.

Abundance: Common. 
Remarks: Small tree or shrub with very hard wood and small white flowers. Found on rocky, open limestone pavements and rocky soils and areas subject to periodic inundation, often on the margins of mangroves. Reported present from all atolls in Tuvalu. Although not common on most of Fogafale Islet, probably because much of it was removed during excavations of the borrow pits and the building of the airstrip during WWII or for the use of its wood, it is locally common in areas bordering some of the old, now reclaimed (infilled) borrow pits on both south and north Fogafale Islet. It is not found on Tepuka, Fualopa and the other smaller uninhabited islets of south Funafuti. According to Woodroffe (1991), it is particularly common and extends far inland from the coast on some of the islets of Nui and is common on supratidal flats bordering mangroves on the lagoon on Vaitupu. One of Tuvalu's most useful plants, the extremely hard wood being used for making a wide range of tools, fishing equipment, weapons and other useful articles. According to Koch (2002), it was especially valued in the past for making pestles, pounders or mallets for preparing pandanus leaves, fishing spears, sticks for prying open giant clams or extracting octopi from the reef, digging sticks (koso), coconut huskers, fish-hooks (especially for palu/oilfish), outrigger pegs and connectives (kiato), dowels (fausaga lakau) and nails (fao) for houses, thatching and netting, needles and drill shafts, combs, forks, scoopnet frames and handles and rat traps, fish traps and eel traps. Also considered one of the best firewoods, and on Nanumea the wood shavings were burned by women to smoke skirts (titi) to preserve them and give them a pleasant fragrance (manogi). Roots reportedly used in medicine to treat stomach ache on Niutao (Koch 2002).

Recorded: CH 1896; JHM 1904; CDW 1991; RRT 1991; RRT \& WAW 1993; SS 1997; RRT 2003; T, F \& F 2010; RRT 2016

Voucher Photographs: DPTV0978, 0979, 2225, 2697, 2698, 2699, 2704, 2706, 2707, 2708, 2899, 2901, 2902

\section{MALPIGHIACEAE (MALPHIGIA FAMILY)}

Malpighia glabra L.

Common Names: Barbados cherry, escobillo

Status: Recent introduction. West Indies and from northern South America to southern Texas in the United States.

Abundance: Rare.

Remarks: Large shrub with pink flowers and small red, cherry-like fruit. Seen in PRAP garden in 2003 and in the Taiwan ICDF Garden as a mature fruit-beraing tree in 2010 and 2016.

Recorded: RRT 2003; T, F \& F 2010; RRT 2016

Voucher Photographs: DPTV1144, 1148, 2410, 2413, 2414, 2415, 2416, 2417, 2433

\section{MALVACEAE (MALLOW FAMILY)}

Abelmoschus esculentus (L.) Moench.

Synonym: Hibiscus esculentus L.

Common Names: okra, gumbo, lady's finger, bindi (Fiji Hindi)

Tuvaluan Name: okala (Seluka 1997)

Status: Recent introduction. Asia.

Abundance: Uncommon.

Remarks: Food plant in the Taiwan ICDF Garden in 2010.

Recorded: SS 1997; T, F \& F 2010

Voucher Photographs: DPTV2400, 2401, 2402, 2425, 3778b

Abelmoschus manihot (L.) Medik.

Synonym: Hibiscus manihot L.

Common Names: bush spinach, edible hibiscus; bush hibiscus spinach, bele (Fiji)

Tuvaluan Name: pele (from the Fijian bele; Ff, Nm) 
Status: Recent introduction. Tropical Asia.

Abundance: Occasional.

Remarks: Food plant introduced a number of times over many years, most recently from Fiji and by UNICEF Family Food Production program. New narrowly-lobed cultivars grown in the Tuvalu Agricultural Department Nursery in 2016 for distribution. Occasional in houseyard gardens and sometimes grown in containers. Very nutritious leafy green vegetable, high in iron, vitamins $\mathrm{A}$ and $\mathrm{C}$ and fiber, which is one of the most important spinaches in Tonga and Melanesia.

Recorded: RRT 1991; RRT \& WAW 1993; SS 1997; RRT 2003; T, F \& F 2010; RRT 2016

Voucher Photographs: DPTV2103, 2129, 2263; DSC02572

Abutilon indicum (L.) Sweet

Common Name: Indian mallow

Tuvaluan Name: aka tā (Nm)

Status: Indigenous. Indo-Pacific.

Abundance: Rare.

Remarks: Not seen on Funāfuti in 1991 or since, but reported present by Hedley (1896) and Woodroffe (1991) on Funafuti. Could have mistaken the similar looking Sida fallax for Abutilon indicum, both of which are found in Nauru (Thaman et al. 1994).

Recorded: CH 1896; CW 1991

\section{Hibiscus rosa-sinensis L.}

Common Names: hibiscus, red hibiscus, China rose

Tuvaluan Names: ‘aute, 'aute kula (“red”; Ff, Nm; TvD); ‘aute kena (“white”; Ff); ‘aute tea (“white”; Nm); 'aute sega ("yellow”; Ff); 'aute sama (“yellow”; Nm)

Status: Recent introduction. Tropical Asia.

Abundance: Rare.

Remarks: Planted ornamental. Reportedly much more common in the past on Funafuti and other atolls where it was planted as a hedge, but seems to have suffered from a serious leaf disease which has killed most of the plants on the island. Hibiscus rosa-sinensis is reportedly relatively intolerant to marginal environments, such as atolls, in which water, nutrition, temperature, high salinity, pests and bacterial leaf diseases (Chase 1986; Wilkerson and Johnson n.d.) which, when combined, may be mutually reinforcing problems that may have accounted for the demise of $H$. rosa-sinensis in Tuvalu. One large flowering plant seen in the Vaiaku Lagi Hotel garden in 2016. Reportedly only about three plants left on Vaitupu Atoll. Flowers, favored for their bright red color, used in house decoration, head garlands (fou) and other body ornamentation; leaves also reportedly woven into garlands in the past. Reportedly also used to embalm corpses (Seluka 1997). One plant seen in 1898 by Mrs. David near the hut of a Samoan trader (Maiden 1904). Red, yellow and other colored varieties reported to have been present at various times in the past (Seluka 1997).

Recorded: JHM 1904; RRT 2003; T, F \& F 2010; RRT 2016

Voucher Photographs: DPTV1129; DSC02548, 03404

\section{Hibiscus tiliaceus L.}

Common Names: beach hibiscus, hibiscus tree

Tuvaluan Names: fou (Tvd); fou, fou fafine (Ff); fau, fau tuu (Nm; Chambers 1984); fau tuu, fau tū (Seluka 1997)

Status: Indigenous. Pantropical, but possibly an aboriginal introduction in Tuvalu.

Abundance: Occasional.

Remarks: Found in houseyard gardens, as a roadside tree, and in tree groves in garden areas. Reported present on Nanumea, Vaitupu and Nukulaelae. Possibly naturally present on the inner margins of mangroves and some coastal forest in the long-distant past. Straight branches used in construction and canoe making and for laundry pegs and other light tools; leaves occasionally used as pig feed and manure (kaiao); bast fiber (inner bark) used to make men's traditional ceremonial skirts (takai), garlands and 
other handicrafts, and for fishing line in the past. Flowers occasionally worn by females as sei over the ear or in the hair. Parts of the plant are used medicinally. In Fiji, the young leaves are used as an analgesic to treat broken bones, sprained ankles and swollen torn muscles and ligaments.

Recorded: CH 1896; JHM 1904; RRT 1991; RRT \& WAW 1993; RRT 2003; T, F \& F 2010; RRT 2016 Voucher Photographs: DPTV0911, 2594, 2595, 2596, 2597, 2598, 2599

Malvastrum coromandelianum (L.) Garcke

Synonyms: Malvastrum tricuspidatum A. Gray; Malva coromandeliana L.

Common Name: false mallow

Status: Recent introduction. Central America to the southern United States.

Abundance: Uncommon.

Remarks: Weed of roadsides and along the airfield.

Recorded: RRT 1991; RRT \& WAW 1993; RRT 2003; RTT 2016

Voucher Photographs: DPTV0675, 0676

Sida fallax Walp.

Common Names: golden mallow, ilima (Hawaii), te kaura (Kiribati)

Tuvaluan Names: akatā (Ff, Nm, Nt); kai ‘uli (Nm); kaula (Seluka 1997)

Status: Indigenous. Indo-Pacific.

Abundance: Rare on Funafuti, but reportedly common on Nanumea, Niutao and some outer atolls.

Remarks: Downy shrub with attractive small yellow-orange hibiscus-like flowers. One small, apparently deliberately planted, population was found just inland from the southwest end of Tepuka Islet, Funafuti in 2010. Reported by Koch (2002) to have occurred all over Niutao in 1963 and is reportedly locally common on Nukulaelae. The similar Abutilon indicum, also known as aktā, was reported present on Funāfuti by Hedley (1896) and Woodroffe (1991), but could have been a mistaken identity for the similar looking Sida fallax (Koch 2002) Flowers used in head garlands (fou) on Niutao, Nui and a number of other atolls. Bark used medicinally to treat children's rashes on Niutao; and the flowers are reportedly used in love magic by women on Nukulaelae, something that might have been learned from Kiribati.

Recorded: T, F \& F 2010

Voucher Photographs: DPTV3142, 3141, 3142, 3143, 3144, 3145, 3146, 3147, 3148, 3149, 3150, 3151, 3152, 3154

Sida rhombifolia L.

Common Names: broomweed, Cuba jute, Paddy's lucerne

Tuvaluan Name: akatāe, pula? (Maiden 1904)

Status: Recent introduction. Pantropical.

Abundance: Common.

Remarks: Shrub with small, hibiscus-like flowers. Weed of roadsides, path sides, waste places and ruderal sites. Fibrous stems used as a toothbrush substitute in Fiji.

Recorded: JHM 1904; CW 1991; RRT 1991; RRT \& WAW 1993; RRT 2003; T, F \& F 2010; RRT 2016

Voucher Photographs: DPTV0600, 0605, 0701, 2471, 2472, 2551, 2578, 2586

Thespesia populnea (L.) Sol. ex Correa

Common Names: Thespian's tree, milo (Hawaii, Polynesia)

Tuvaluan Name: milo (Ff, Nm; Tvd)

Status: Indigenous. Paleotropics.

Abundance: Rare.

Remarks: One tree seen near path to airfield in Vaikufou settlement to the north or the airport terminal in 1991 and 1993, a couple trees planted recently in houseyard gardens and one large tree about $7 \mathrm{~m}$ high is found along the road along the airstrip south of the airport in 2016. Apparently more common in the past and reported present by Maiden (1904) in 1898 where it was reportedly growing "along swamp near village.” Reported present on Nanumea, Nanumaga, Vaitupu, Nukufetau and Nukulaelae by Woodroffe 
(1991) and an occasional component of natural or planted vegetation, possibly bordering mangroves and Pemphis. Wood favored for carving in the past and used to makes, boxes, chairs, furniture, wooden pillows, cricket bats, fishing rods and other things. One of the most highly valued carving woods in the Pacific Islands. Bark is used medicinally for a number of purposes. Flowers reportedly used in head garlands (fou) and worn as sei by females over the ear or in the hair. Considered a threatened species on Funafuti that should be replanted.

Recorded: CH 1896; JHM 1904; CW 1991; RRT 1991; RRT \& WAW 1993; RRT 2003; T, F \& F 2010; RRT 2016

Voucher Photographs: DSC03118, 03119, 03123, 03124

\section{MELiACEAE (MAHOGANY FAMiLY)}

\section{Melia azedarach L.}

Common Names: Indian lilac, China berry, Persian lilac, pride of India

Status: Recent introduction. Tropical Asia.

Abundance: Rare.

Remarks: Single mature tree in Agricultural Department nursery at Vaiaku and one mature tree in a houseyard garden just north of the airport.

Recorded: RRT 1991; RRT \& WAW 1993; RRT 2003; T, F \& F 2010

Voucher Photographs: DPTV0667, 0951, 0952, 0960, 3481, 3482, 3483, 3484, 3485

\section{MORACEAE (MULBERRY FAMILY)}

Artocarpus altilis (Park.) Fosb.

Synonyms: Artocarpus incisus (Thunb.) L.f.; A. communis Forst.

Common Name: breadfruit

Tuvaluan Name: mei (Ff, Nm, Nt, Nui; Tvd)

Status: Aboriginal introduction? Malayo-Pacific.

Abundance: Abundant.

Remarks: Planted staple food tree in houseyard gardens and in agricultural areas near taro pits on inhabited islets. Also seen the Agricultural Department nursery and in sustainable agriculture for climate change plots in 2016. One of the most important staple food plants in Tuvalu, although Koch (2002) says that on Niutao it was thought to have been introduced following the arrival of the missionaries. Many named cultivars are recognized including māfalā, vailuā and pōkēke, the latter which is probably $A$. mariannensis (see below). The trunk is sometimes used for boat hulls. Ripe fruit cooked baked, roasted or boiled as a staple food, made into puddings, and, in the past, buried in underground fermentation pits from 1 to 3 month to make fermented breadfruit (mei pala), to preserve surplus production for times of food shortage. Sap used as an adhesive, for caulking canoes and as chewing gum. Leaves are used for wrapping food for cooking, covering earthen ovens and fermentation pits, parcelization of fresh food, and as plates. Parts used medicinally for curing ear aches made by crushing juice from the tender growing tips at the ends of branches. Dried leaves used for fertilizer (kaiao; Koch 2002). Important staple food tree throughout the Pacific Islands. One of the most important trees for protection and replanting for food security.

Recorded: JHM 1904; CDW 1991; RRT 1991; RRT \& WAW 1993; SS 1997; RRT 2003; T, F \& F 2010; RRT 2016

Voucher Photographs: DPTV0901, 0942, 1182, 2814, 2819, 2826, 2827, 2830, 3662, 3663, 3693, 3696, 3697, 3698, 3699; DSC02576

Artocarpus mariannensis Trec.

Common Name: Marianas breadfruit

Tuvaluan Names: mei (general term for all breadfruit species.); pokēkē (specific term for A. mariannensis; Ff, Nm; Tvd) 
Status: Aboriginal introduction or recent introduction from Kiribati? Micronesia.

Abundance: Occasional.

Remarks: Planted staple fruit tree in houseyard gardens and near settled areas. Same uses as for A. altilis, but fruit of A. mariannensis is eaten both raw and cooked.

Recorded: RRT 1991; RRT \& WAW 1993; RRT 2003; T, F \& F 2010; RRT 2016

Voucher Photographs: DPTV3700, 3701

Ficus carica L.

Common Name: common fig

Tuvaluan Name: felo palagi (Seluka 1997)

Status: Recent introduction. Probably originally native to Southwest Asia, but spread in ancient times to the Mediterranean area.

Abundance: Uncommon.

Remarks: Single potted seedling in the Agricultural Department nursery, Vaiaku. Planted at PRAP experimental nursery in 2003, the Taiwan ICDF Garden in 2010, and in the Agriculture Department nursery in 2016. Edible fruit.

Recorded: RRT 1991; RRT \& WAW 1993; SS 1997; RRT 2003; T, F \& F 2010; RRT 2016

Voucher Photographs: DPTV1150, 2309, 2310; DSC03062, DSC02579, DSC02591

\section{Ficus tinctoria Forst. f.}

Common Names: Dyer's fig, native fig

Tuvaluan Names: felo (Ff, Nm, Nt; Tvd); felo lasi ("large fruit”; Ff), felo fōliki ("small fruit”; Ff); felo (large fruited variety; Nm), felo Nanumaga (small fruited variety; Nm); pelo (Nui; Woodroffe 1991)

Status: Indigenous? Southeast Asia to Polynesia and Micronesia, but possibly an aboriginal introduction.

Abundance: Occasional.

Remarks: Planted food tree in houseyard gardens and uncommon in garden areas. Occasionally growing wild in inner coastal vegetation and sometimes near the coast. Found growing naturally slightly inland near a Pisonia grove on Fualopa Islet in 1993 and common on the northwest end of Tepuka Islet in 2003 and 2010. Also seen the Agricultural Department nursery and in sustainable agriculture for climate change plots in 2016. Wood occasionally used for posts for cooking huts and chicken pens, planting sticks and as firewood. Fruit cooked and made into a pudding with coconut and sugar and fed to pigs and formerly cooked and dried in the sun and stored in coconut shells as emergency food. Ripe fruits also reportedly eaten raw and a favorite fruit of birds. Fruits also strung together into necklaces (ula) by children. Leaves fed to pigs and yellowed mature leaves made into the head-dress (kula) for the inauguration of chiefs on Niutao as a symbol of the food-giving felo so that it would continue to bear. Climbing ropes formerly made from the elastic baste fiber (inner bark; Koch 2002). Parts reportedly used medicinally. Reportedly much less common than in the past, possibly from overuse for feeding to pigs.

Recorded: CH 1896; JHM 1904; CDW 1991; RRT 1991; RRT \& WAW 1993 (24155?); SS 1997; RRT 2003; T, F \& F 2010; RRT 2016

Voucher Photographs: DPTV0678, 0848, 0849, 0853, 1137, 2188, 2189, 2190, 3005, 3127, 3128, 3129, 3130, 3131, 3132, 3133, 3134; DSC02573, DSC02579

\section{MORINGACEAE (MORINGA FAMILY)}

\section{Moringa oleifera Lam.}

Synonyms: Guilandina moringa L.; Moringa (L.) Millsp.

Common Names: horseradish tree, drumstick tree

Tuvaluan Name: saitiani (from the Hindi saijan; Seluka 1997)

Status: Recent introduction. India.

Abundance: Rare.

Remarks: One healthy plant seen at the Agricultural Department nursery at Vaiaku in the early 1991 and planted in PRAP experimental nursery 1993. Two large trees seen at former Filipino doctor's garden 
where Cuban doctors lived in 2010. Planted in the improving food security through demonstrating sustainable agroforestry systems plot in south Fogafale Islet in 2016. Seems to do well in the harsh conditions in Tuvalu. Nutritious edible leaves, fruit and flowers cooked as vegetables. Introduced as a nutritious green vegetable to enrich local diets. Popular leafy green vegetable among Indians, Sri Lankans and Filipinos.

Recorded: RRT 1991; RRT \& WAW 1993; SS 1997; RRT 2003; T, F \& F 2010; RRT 2016

Voucher Photographs: DPTV0910a, 1030a, 1031, 1143, 1155, 1161b, 2670, 2671, 2672

\section{MYRTACEAE (MYRTLE FAMILY)}

\section{Eucalyptus sp.}

Common Names: eucalyptus, gum tree

Tuvaluan Name: iukalipi (Seluka 1997)

Status: Recent introduction. Australia?

Abundance: Rare or extirpated.

Remarks: Mature trees planted in agricultural plot and in front of old Government Buildings in 2003 and reported present by Seluka (1997). Not seen in 2010 after the construction of the new Tuvalu Government Building.

Recorded: SS 1997; RRT 2003

\section{Psidium guajava L.}

Common Name: guava

Tuvaluan Name: kuava (Ff, Nm)

Status: Recent introduction. Tropical America.

Abundance: Uncommon.

Remarks: Food tree. Two mature trees seen and Vaiakufou and one tree in poor health at the Agricultural Department nursery at Vaiaku in 2003; matured pruned tree seen in Taiwan farm in 2016. Ripe fruit eaten and wood used as firewood where available. Doesn't not seem to survive well and does not seem to bear fruit on atolls.

Recorded: RRT 1991; RRT \& WAW 1993; SS 1997; RRT 2003; RRT 2016

Voucher Photographs: DSC02620

Syzygium malaccense (L.) Merr. and Perry

Synonym: Eugenia malaccensis L.

Common Names: Malay apple, mountain apple

Status: Recent introduction. Southeast Asia.

Abundance: Extirpated.

Remarks: Immature seedling in the Bank of Tuvalu gardens. Common fruit tree in the high island Pacific that doesn't not seem to thrive on atolls.

Recorded: RRT 2003

\section{NYCTAGINACEAE (FOUR-O'CLOCK FAMILY)}

\section{Boerhavia repens L.}

Synonym: Boerhavia diffusa sensu auct non L.

Common Names: boerhavia, pigweed

Tuvaluan Names: mouku solo (Ff); mouku tolo (Nm); kalisi-lisi, kisi (Maiden 1904)

Status: Indigenous. Africa to Hawai’i, but possibly an aboriginal introduction.

Abundance: Rare, or extirpated.

Remarks: Reported present on Funafuti in 1898 in Maiden (1904) where it is suggested that it might have been imported. Also reported present on Niulakita by Woodroffe (1991), but not seen since 1991, and 
may have been a mistaken identification for Boerhavia tetrandra G. Forst. For which B. diffusa var. tetrandra (G. Forst) Heimeri is a synonym.

Recorded: JEM 1904; CDW 1991

Boerhavia tetrandra G. Forst.

Synonym: Boerhavia diffusa var. tetrandra (Forst.) Heimerl

Tuvaluan Names: kisikisi (Ff); kalihilihi (Nm; Chambers 1984); eveeve lauefa (Nt; Koch 2002)

Status: Indigenous. Central Pacific atolls.

Abundance: Occasional to locally common.

Remarks: Small prostrate creeping herb with rounded leaves and small pinkish flowers. Common on outer islets on the inner beach ridge and in openings in scrub and forest. Reported present by Maiden (1904), probably as B. diffusa. Found in scattered dense populations on Fualopa Islet in 1993 amongst Pisonia groves and Asplenium nidus. Common on Te Puka and other unpopulated islets in 2003 and 2010.

Reported from all atolls except Niulakita by Woodroffe (19991). Stems and leaves used in head and arm garlands and in love and death spells on Niutao (Koch 2002).

Recorded: JHM 1904; RRT \& WAW 1993 (24169); RRT 2003; T, F \& F 2010

Voucher Photographs: DPTV0730, 0731, 0735, 0742, 1070, 3092, 3093, 3094, 3095, 3110, 3111, 3114a, 3115, 3116a, 3117a, 3122, 3123, 3184, 3185, 3194, 3195, 3196, 3197a, 3198a, 3199

\section{Bougainvillea glabra Choisy}

Common Names: bougainvillea, lesser bougainvillea

Tuvaluan Names: akanita (Ff; Tvd); akanta (from Kiribati te akanta; Nm)

Status: Recent introduction. Brazil.

Abundance: Uncommon.

Remarks: Planted ornamental. Arching thorny shrub with shiny green leaves and very attractive small white flowers with purple flower-like bracts. Flowers used in garlands and decorations.

Recorded: RRT 1991; RRT \& WAW 1993; SS 1997; RRT 2003; T, F \& F 2010; RRT 2016

Bougainvillea x buttiana Holttum \& Standley

Misapplied Name: Mistakenly identified as Bougainvillea spectabilis Willd.

Common Name: hybrid bougainvillea

Tuvaluan Names: akanita (Ff; Tvd); akanta (from Kiribati te akanta; Nm)

Status: Recent introduction. Horticultural origin.

Abundance: Occasional.

Remarks: Planted ornamental in household gardens and landscaping. Arching thorny shrub with green leaves and small white flowers with very attractive red, salmon, white, pink or red flower-like bracts. According to Whistler (2000b), it is commonly misidentified as the Brazilian species, B. spectabilis Willd., and is apparently a hybrid of two other species, one of which is possibly B. spectabilis. Flowers used in head garlands (fou) and house decorations.

Recorded: RRT 1991; RRT \& WAW 1993; RRT 2003; T, F \& F 2010; RRT 2016

Voucher Photographs: DPTV2271, 2385, 2393, 3529, 3747, 3748

Mirabilis jalapa L.

Common Names: four-o'clock, marvel of Peru, false jalap

Tuvaluan Names: teao’aua (Ff, Nm); peteli? (Seluka 1997)

Status: Recent introduction. Peru.

Abundance: Occasional.

Remarks: Ornamental herb or subshrub with pink, purple, yellow or white flowers. Planted in houseyard gardens. Flowers used in head garlands (fou) and house decoration; flowers often strung on coconut leaflet midribs (tuaniu).

Recorded: RRT 1991; RRT \& WAW 1993; SS 1997; RRT 2003; T, F \& F 2010; RRT 2016

Voucher Photographs: DPTV0536, 2823, 2876 
Pisonia grandis R. Brown

Synonym: Pisonia alba Span.

Common Names: pisonia, lettuce tree, bird-catcher tree

Tuvaluan Names: puka, pukavai (Ff, Nt, Nui); puka fai kaiao (“make fertilizer”; Nm)

Status: Indigenous. Indo-Pacific.

Abundance: Occasional to locally common, but uncommon on Fogafale, the man islet of Funafuti.

Remarks: Common and dominant species in inner and coastal forest and woodland on uninhabited islets and forming stands on the west end of Tepuka Islet. A major component of indigenous inland forest and woodland before the expansion of coconut monoculture. Occasionally planted in houseyard gardens and around pig rearing areas on the main inhabited islets. A favored nesting or rookery species for sea birds. Leaves fed to pigs and used as mulch or fertilizer (kaiao) for giant swamp taro and other plants. Leaves used medicinally to treat sores and in death spells on Niutao (Koch 2002). Wood apparently used for some types of flooring (Seluka 1997).

Recorded: CDW 1991; RRT 1991; RRT \& WAW 1993; SS 1997; RRT 2003; T, F \& F 2010

Voucher Photographs: DPTV0703, 0738, 0748, 0762, 1064, 1076, 1115, 1116, 1120, 2821, 2859, 3155, 3173, 31801, 3186, 3203, 3210, 3211, 3212, 3217, 3218, 3219, 3221, 3222, 3223, 3224, 3235, 3236, 3238a, 3238b, 3313d, 3314d, 3315d, 3316d, 3317d

\section{OlacACEAE (OlaX FAMILY)}

\section{Ximenia americana L.}

Synonym: Ximenia elliptica Forst. f.

Tuvaluan Names: talatalāmoa (Tvd; Woodroffe 1991); kanana (Nui; Woodroffe 1991)

Status: Indigenous. India and Sri Lanka to Australia and into the Pacific islands to the Tuamotus and to tropical and subtropical America and Africa.

Abundance: Rare or ephemeral.

Remarks: Reported present from Nanumea and Nui, but not from Funafuti or the other Tuvalu atolls (Woodroffe 1991). Small fruit-bearing shrub with spines along the branches that probably arrives periodically as a drift seed. Seen by senior author on Tarawa atoll in Kiribati, where the fruit was reportedly eaten by local children. The name talatalāmoa or a cognate is the same name in Tonga and Niue for the more widespread, often ephemeral drift-seed dispersed, thorny shrubby vine (Caesalpinia bonduc).

Recorded: CDW 1991

\section{OLEACEAE (OLIVE FAMILY)}

Jasminum sambac (L.) Ait.

Common Names: Arabian jasmine, pikake (Hawaii)

Tuvaluan Name: pitasi (Ff, Nm)

Status: Recent introduction. India.

Abundance: Occasional.

Remarks: Planted ornamental shrub with fragrant white flowers. Highly fragrant flowers used in head and neck garlands (fou and ula) and highly valued for scenting special coconut oil (sinu) known as sinu pitasi.

Recorded: RRT 1991; RRT \& WAW 1993; RRT 2003; T, F \& F 2010; RRT 2016

Voucher Photographs: DPTV0898, 2060, 2211, 3519, 3520, 3546, 3548

\section{ONAGRACEAE (EVENINg PRIMRose FAMILY)}

Ludwigia octovalvis (Jacq.) Raven

Synonyms: Jussiaea suffruticosa L.; Oenothera octovalvis Jacq.

Common Names: swamp primrose, willow primrose, Mexican primrose-willow 
Tuvaluan Names: lakau pula sega (“yellow flower”; Ff); lakau pula (Nt; Koch 2002)

Status: Recent introduction. Pantropical with uncertain origin.

Abundance: Common.

Remarks: Erect perennial herb with narrow leaves and yellow flowers. Weed in swampy areas, drainage ditches and excavated taro pits (pela) in Vaiaku. Reported present in 1898 by Maiden (1904) and possibly introduced with "taro culture.” Reported present on all atolls except Nukufetau (Woodroffe 1991). Flowers used in head garlands (fou) and leaves used as manure or mulch (kaiao) for swamp taro.

Recorded: JHM 1904; CDW 1991; RRT 1991 (24325); SS 1997; RRT 2003; T, F \& F 2010; RRT 2016 Voucher Photographs: DPTV0674, 2169, 2170, 2171, 2579, 2580, 3396, 3397, 3743

\section{OXALIDACEAE (WOOD SORREL FAMILY)}

\section{Averrhoa carambola L.}

Common Names: carambola

Tuvaluan Name: kalampola (Ff; Seluka 1997)

Status: Recent introduction. Malesia and Southeast Asia.

Abundance: Rare.

Remarks: Planted as an experimental fruit tree at the PRAP garden in the early 1990s, but not seen since 1993.

Recorded: T \& W 1993, SS 1997

\section{Oxalis corniculata L.}

Common Name: yellow wood sorrel

Tuvaluan Name: lau kāpa? (Ff?; Seluka 1997)

Status: Recent introduction.

Abundance: Rare, possibly extirpated.

Remarks: Reported present in by Seluka (1997), but with no location; not recorded by current authors. Recorded: SS 1997

\section{PASSIFloraceae (PASSION FLOWER FAMILY)}

\section{Passiflora edulis Sims}

Common Name: passionfruit

Tuvaluan Name: pasinifuluti (Seluka 1997)

Status: Recent introduction. Brazil.

Abundance: Uncommon.

Remarks: Seen growing well and bearing fruit in one houseyard garden in north Fogafale Islet in 2010. Pulp of ripe fruit eaten and made into juice. Supplementary food plant in many parts of the Pacific and currently or formerly an important cash crop in Niue, Fiji, Samoa, Hawaii and Papua New Guinea.

Recorded: SS 1997; T, F \& F 2010

Voucher Photographs: DPTV2723, 2725, 2747, 2874

\section{Phytolacaceae (PoKeWEed Family)}

\section{Rivina humilis L.}

Common Names: coral berry, rouge plant

Status: Recent introduction. Tropical America, now widely naturalized in Indo-Malesia and the Pacific Islands.

Abundance: Common.

Remarks: Reported as “abundant; a common weed” by a Mrs. David as early as 1897 in Maiden (1904) and by Woodroffe (1991), but from no other atoll within Tuvalu. Reportedly originally cultivated as an ornamental plant and first reported present in the Pacific Islands in Hawai'i in 1871. Possibly introduced 
from Hawai'i or Fiji by boat where it is now a common weed in some coastal and inland sites. Weed of gardens, roadsides, taro gardens and ruderal sites, and occasionally on coral rubble, often in shady sites on Fogafale Islet, Funafuti and on Funafala Islet, south of Fogafale.

Recorded: JHM 1904; CDW 1991; RRT 1991; RRT \& WAW 1993; RRT 2003; T, F \& F 2010

Voucher Photographs: DPTV0518, 0519, 0688, 2031, 2116, 2120, 2166, 2486, 3455, 3486, 3487

\section{PiPERACEAE (PEPPER FAMILY)}

Peperomia pellucida (L.) HBK.

Synonyms: Peperomia pellucidum L.; P. lineata Miq. ex Yuncker

Common Name: peperomia

Status: Recent introduction. Tropical America.

Abundance: Rare.

Remarks: Small slightly succulent plant with heart-shaped leaves. Weed in garden on the north side of the Tuvalu Government Building in 2010, possibly introduced from Fiji.

Recorded: T, F \& F 2010

Voucher Photograph: DPTV3361

\section{Piper aduncum L.}

Common Name: hooked pepper bush

Status: Recent introduction.

Abundance: Rare or extirpated.

Remarks: Indigenous to the West Indies, apparently introduced into Fiji in the 1920s, but now dispersed by birds or bats and widely naturalized throughout the wet and intermediate zones of Fiji. One shrub found in new gardens of the new Tuvalu Government Building, apparently introduced accidentally with ornamental plants used in the landscaping in 2004. A potentially invasive weed that should be eradicated. Not seen in 2016 and presumed to be extirpated.

Recorded: T, F \& F 2010

Voucher Photographs: DPTV2519, 2520, 2521

\section{Polemoniaceae (Phlox Family)}

Phlox x drummondi Hook.

Common Name: phlox

Status: Recent introduction. Texas.

Abundance: Rare.

Remarks: Planted ornamental in new Vaiaku Lagi Hotel flower bed. Not seen in 2016.

Recorded: RRT 2003; T, F \& F 2010

\section{Polygonaceae (BuckWheat Family)}

Coccoloba uvifera (L.) Jacq.

Synonym: Polygonum uvifera L.

Common Name: sea grape

Status: Recent introduction. Tropical America.

Abundance: Rare or extirpated.

Remarks: Single mature tree seen next to the Provident Fund office, Vaiaku from 1991 to 2003. Not seen since.

Recorded: RRT 1991; RRT \& WAW 1993; RRT 2003 


\section{Portulacaceae (Purslane Family)}

Portulaca australis Endl.

Synonyms: Portulaca samoensis v. Poelln.; Portulaca pilosa sensu auct. non L.

Common Name: small-leaf portulaca

Tuvaluan Names: katuli (Ff, Nm; Tvd); tuli (Nt; Koch 2002)

Status: Indigenous. Pantropical?

Abundance: Occasional.

Remarks: Perennial succulent herb with small narrow rounded tubular leaves and terminal yellow flowers.

Reported present on Nanumea, Niu, Vaitupu and Nukulaelae, but not from Funafuti by Woodroffe

(1991). Seen on Funafuti in 2003 and 2010 as a weed on the back slope of the summit of the coral shingle bank near the pig rearing pens near the north end of the airstrip and near the Blue Ocean Restaurant near the south end of Fogafale Islet; seen again in 2016 growing on the lagoonside beach ridge near the reclaimed borrow pit area north of the rubbish dump in north Fogafale. Koch (2002) reports that, on Niutao, where it "grows wild, thrives all over the island, even in the village area", the leaves, roots and tubers are eaten as an emergency food during times of drought and food shortage; and the flowers are added to coconut oil used in love spells. He also reports that is eaten as a nourishing and pleasant tasting dish on some atolls in Kiribati, but not on Niutao. Plant also fed to pigs.

Recorded: RRT 2003; T, F \& F 2010; RRT 2016

Voucher Photographs: DPTV0919, 0929, 2250, 2612, 2613, 2614, 2801, 2802; DSC03248, DSC03252, DSC03259

Portulaca grandiflora Hook.

Common Names: portulaca, purslane, pigface

Status: Recent introduction. Brazil.

Abundance: Rare.

Remarks: Perennial succulent prostrate to ascending herb with small narrow pointed leaves and purple or pink, red, yellow or white flowers. Planted ornamental and pot plant seen in 2003.

Recorded: RRT 2003

Portulaca lutea Solander ex Forst. f.

Synonym: Portulaca johnii v. Poelln.

Common Name: purslane

Tuvaluan Name: katuli (Ff, Nm; Tvd)

Status: Indigenous. From New Caledonia eastward to Pitcairn Island and Hawai'i and Kiribati in Micronesia.

Abundance: Rare; probably absent or extirpated on Funafuti.

Remarks: Small succulent perennial herb with fleshy leaves and bright yellow terminal flowers. Reported present on Nanumea and Niu by Woodroffe (1991), but not from Funafuti. Also reported from Tuvalu by Seluka (1997) with no location. Normally found in open habitats on limestone, rocky or gravelly or sandy shores and in open areas in coconut plantations, often on uninhabited islets. Possibly replaced by the introduced Portulaca oleracea. Plant eaten by and fed to pigs and seeds eaten by chickens; leaves cooked and eaten in times of food scarcity.

Recorded: CDW 1991; SS 1997

Portulaca oleracea L.

Common Name: pigweed, common purslane, wild purslane

Tuvaluan Names: katuli (Ff, Nm; Tvd); poipoi? (Nm)

Status: Recent introduction. Of uncertain origin, but now cosmopolitan.

Abundance: Common.

Remarks: Small succulent perennial herb with fleshy leaves and yellow flowers and reddish stems. Weed in gardens, roadsides, near pigsties and waste places, especially in sandy soils. Plants eaten by and fed to 
pigs and reportedly cooked and eaten in times of food shortage. Reported present by Maiden (1904) from Funafala Islet, but possibly could be a mistaken identity of Portulaca lutea.

Recorded: JHM 1904; RRT 1991; RRT \& WAW 1993; SS 1997; RRT 2003; T, F \& F 2010; RRT 2016

Voucher Photographs: DPTV0563, 2025, 2156, 2157, 2431, 2608, 2800

Portulaca umbraticola Kunth subsp. umbraticola

Synonym: Portulaca oleracea L. x Horticultural varieties of some authors

Common Names: purslane, wingpod purslane

Tuvaluan Name: katuli pālagi (Ff, Nm)

Status: Recent introduction. Of horticultural origin, but possibly native to the United States.

Abundance: Common.

Remarks: Planted ornamental and potplant with succulent leaves and yellow, pink, light orange and othercolored flower forms. The taxonomy of this species is often confused, with plants with flat leaves being referred to as $P$. oleracea and those with cylindrical leaves as $P$. grandiflora, with some authorities considering it a hybrid of the two but most authorities believing that is actually a variant of $P$. umbraticola (Lennon n.d.). Colorful flowers sometimes used in head garlands (fou).

Recorded: RRT 1991; RRT \& WAW 1993; RRT 2003; T, F \& F 2001; RRT 2016

Voucher Photographs: DPTV2195, 2196, 2646, 2647, 2648, 2718, 2843, 3506, 3507, 3508, 3524, 3769, 3772

\section{RHAMNACEAE (BUCKTHORN FAMILY)}

Colubrina asiatica (L.) Brongn.

Synonyms: Ceanothus asiaticus L.; Ceanothus capsularis Forst. $\mathrm{f}$.

Common Names: soapbush, hoop withe

Tuvaluan Names: lakau sopu (Ff); lakau hopu (“soap bush”; Nm)

Status: Indigenous? Paleotropical.

Abundance: Rare or extirpated.

Remarks: Seen in 1993 and as an apparently planted ornamental in one houseyard garden in north Fogafale Islet in 2003 but not seen since. Reportedly present in the past near the Telecom Building on Funāfuti and on Nanumea and Vaitupu on some of the other atolls, although not reported from any of the atolls in Tuvalu by Woodroffe (1991) or Seluka (1997). A common coastal plant in littoral vegetation on large islands elsewhere in the Pacific and seen in small populations on the atolls of the Marshall Islands and Tikehau Atoll in the Tuamotu Archipelago in French Polynesia by the author. Leaves used with water in many areas of the Pacific to produce a cleansing, soap-like lather, thus the local Tuvaluan name, lakau sopu ("soap plant”).

Recorded: RRT \& WAW 1993 (24168); RRT 2003

Zizyphus mauritiana Lam.

Common Name: Indian jujube

Tuvaluan Name: tutupi (“jujube”; Ff; Seluka 1997)

Status: Recent introduction. Asia and Africa.

Abundance: Rare.

Remarks: Fruit tree planted as part of the PRAP project in the 1990s and in the Taiwan ICDF Garden in 2010. Ripe fruit eaten.

Recorded: SS 1997; T, F \& F 2010

Voucher Photograph: DPTV2307

\section{RHIZOPHORACEAE (MANGROVE FAMILY)}

Rhizophora stylosa Griff.

Synonyms: Rhizophora mucronata Lam. var. mucronata; R. mucronata Lam. var. stylosa Schimper 
Common Name: spotted mangrove

Tuvaluan Names: togo (Ff, Nm, Nt); te tongo (Nui); pika (term for fruit, Ff; Hedley 1896)

Status: Indigenous. Indo-Pacific Asia to Micronesia and Western Polynesia as far east as Samoa.

Abundance: Locally abundant.

Remarks: Abundant to the east of the airfield surrounding the lagoon or back-beach intertidal basin behind the ocean-coast coral rubble and shingle rampart. An 1896 geological map of Fogafale Islet shows that this back beach swamp area covered a much more extensive area of the east-central part of the islet in the past before the construction of the airstrip in 1942 and the expansion of the government settlement (Kayanne 2009). Also present on all other Tuvalu atolls except for Nukulaelae. The most extensive areas of Rhizophora mangrove in Tuvalu are found around the landlocked central lagoon of Nanumaga, the southeastern lagoon of Nui, along the northeastern shore of the south portion of the lagoon on Vaitupu (Woodroffe 1991); and surrounding the lagoon (namo) on Niutao (Koch 2002). One of Tuvalu's most useful and ecologically important trees, especially for protecting coastal areas. Mangroves are important roosting sites for seabirds and an important habitat for a number of crabs, shellfish, milkfish and other finfish and marine food species. The hard wood is use to make parts of houses and cooking huts (faletalimatagi), tool handles, planting sticks (koso talo), coconut huskers (pukukoso), mallets or beaters (kaukini makakafa) for beating and cleaning tanned coconut fiber, frames of scoopnets (taetae, taetulituli, taesasave) and bird snares (malei), long-toothed combs (kauseluselu), ear-rings for slit ears (mama), the shaft for the shark-tooth lancelet (nifo tufuga) used by traditional healers, and other useful objects. Pieces of the trunk are used as a furnace for burning coral limestone (lase) and wood occasionally used as firewood. The inner bark and stems are used by women to make dye to color strips of treated pandanus (kie) black for weaving into mats, fans, dancing skirts (titi faitele) and other plaited materials. The leaves are an important pig feed. The pre-germinated seeds (fruit) are used on Niutao in the traditional crown or head-dress (kula) worn during the inauguration of the high chief of the Fuatia clan, because the aliki ("high chief") should be strong like the mangrove; and the term kai togo ("eat togo") is reportedly a derogatory or joking term used to refer to the people of Nanumaga who reportedly used to eat the fruit of mangrove in times of food scarcity (Koch 2002).

Recorded: CH 1896; JHM 1904; CDW 1991; RRT 1991; RRT \& WAW 1993; SS 1997; RRT 2003; T, F \& F 2010; RRT 2016

Voucher Photographs: DPTV0915, 0916, 0921, 0923, 0928, 2582, 2589, 2622, 2623, 2624, 2626, 2627, 2628, 3566a; DSC03202

\section{RUBIACEAE (COFFEE FAMILY)}

Dentella repens J. \& G. Forst.

Common Name: dentella

Status: Recent introduction. Pantropical.

Abundance: Rare.

Remarks: Small-leaved prostrate creeping weed with small white flowers seen in lawn in the entrance to the Taiwan Mission residence in north Fogafale and across from Blue Ocean Bar in south Fogafale; seen again as a roadside weed in N. Fogafale in 2016.

Recorded: T, F \& F 2010; RRT 2016

Voucher Photographs: DPTV2757, 2758, 2924; DSC03300

Gardenia augusta (L.) Merr.

Synonyms: Varneria augusta L.; Gardenia florida L.; G. jasminoides Ellis; G. radicans Thunb.

Common Name: august gardenia

Tuvaluan Names: tiale Fiti ("gardenia from Fiji”; Ff)

Status: Recent introduction. China.

Abundance: Uncommon.

Remarks: Planted ornamental with fragrant white compound flowers in two houseyard gardens Vaiaku in 2010. Flowers used in garlands and flower arrangements. 
Recorded: T, F \& F 2010

Voucher Photographs: DPTV3494, 3495, 3496

\section{Gardenia taitensis DC.}

Common Names: Tahitian gardenia, tiare Tahiti (Tahiti)

Tuvaluan Names: tiale (Ff, Nm; TvD); siale (Nui; Woodroffe 1991)

Status: Possibly an aboriginal introduction to Tuvalu. Probably native to Fiji, Tonga and possibly Niue where it grows on coastal limestone cliffs and outcrops.

Abundance: Occasional to common.

Remarks: Planted ornamental in houseyard gardens, sometimes in significant numbers. Also listed as present on Nanumea, Nui, Vaitupu and Nukulaelae (Woodroffe 1991). Also seen the Agricultural Department nursery and in sustainable agriculture for climate change plots in 2016. Reported present on Funafuti in 1897 where: “The flowers are much prized for wreaths.” (Maiden 1904). One of Tuvalu's most important fragrant plants. Flowers used in leis (ula) and head garlands (fou), worn as sei over the ear or in the hair by females and for scenting coconut oil (sinu, hinu), with sinu tiale being one of the most highly regarded sinu. Wood used for carving cricket balls and other implements and tools. The tiale was reportedly considered a gift from the gods in the past (Seluka 1997).

Recorded: CH 1896; JHM 1904; RRT 1991; RRT \& WAW 1993; SS 1997; RRT 2003; T, F \& F 2010; RRT 2016

Voucher Photographs: DPTV0545, 0980, 0981, 2137, 2657; DSC02575

\section{Guettarda speciosa L.}

Common Names: beach gardenia, sea randa, zebra wood

Tuvaluan Names: pua (Ff, Nm; Tvd); pua vao (Nt; Koch 2002); uli (Nui; Woodroffe 1991)

Status: Indigenous. Tropical Asia to the Pacific Islands.

Abundance: Abundant.

Remarks: Planted in houseyard gardens and common in abandoned coconut plantations and occasional in coastal strand forest on both ocean and lagoon coasts on main islets. Occasional around excavated taro garden areas (pela). Common in forest and woodland on uninhabited islets, such as Tepuka. Reported present on all of the atolls of Tuvalu. Flowers and young leaves (mulo te pua) used in head garlands (fou), neck garlands (ula) and waist garlands (titi), worn as sei by females over the ear or in the hair, the flowers are used for scenting coconut oil to make the highly regarded perfumed oil (sinu pua), and the unopened flowers were worn in slits in the ears in the past. Leaves used as mulch or compost (kaiao) and to cover the earthen oven (umu) and young leaves worn in head garlands and as ear pendants. Relatively soft wood used for house posts, beams and other house and cooking hut parts, canoe parts, thatching needles (atolau), fishing clubs (toko), shovels (pikapika), flyingfish net handles (kautae sasave), stilts and to carve inferior bowls. Also a favored firewood. Dead pieces of the trunk used to make firesticks in the past and dead wood burned in the earth oven to smoke skirts to give them a good fragrance (Koch 2002). Bark used medicinally to treat stomach ache and other illnesses and as an abortifacient. Plant also used in black magic.

Recorded: CH 1896; JHM 1904; RRT 1991; RRT \& WAW 1993; SS 1997; RRT 2003; T, F \& F 2010; RRT 2016

Voucher Photographs: DPTV0713, 0729, 0804, 0817, 0998, 2643b, 2980, 2986a, 3006, 3011, 3012, 3013, 3014, 3015, 3015, 3071, 3072, 3075, 3263b, 3332b, 3409, 3516b, 3566b, 3658

Hedyotis romanzoffiensis (C \& S) Fosb.

Status: Indigenous. Endemic to Polynesia from Tuvalu and Tokelau east to the Line, Tuamotu and Austral Islands.

Abundance: Uncommon.

Remarks: Normally found in sunny sandy habitats of atolls. Reported present on Nanumea and Nui by Woodroffe (1991), but not from Funafuti (CDW 1991).

Recorded: CDW 1991 
Ixora casei Hance

Synonyms: Ixora duffii Baine; I. carolinensis Hosok.; I. longifolia Smith

Common Name: giant red ixora

Tuvaluan Names: kasilu (from katiru in Kiribati; Ff); lakau pula kula ("red-flowered shrub”; Ff, Nm); kula toto ("blood red"; Seluka 1997)

Status: Recent introduction. Caroline Islands.

Abundance: Common.

Remarks: Planted ornamental with bright red flowers in houseyard gardens. Flowers used in head garlands

(fou), neck garlands (ula) and worn over the ear or in the hair as a sei and used in flower arrangements.

Recorded: RRT 1991; RRT \& WAW 1993; SS 1997; RRT 2003; T, F \& F 2010; RRT 2016

Voucher Photographs: DPTV0682, 0910b, 2048, 2056, 2088, 2828, 2940b, 3554, 3555, 3556; DSC02446, 02446

Ixora chinensis Lam.

Common Name: Chinese ixora

Tuvaluan Name: kasilu (Ff)

Status: Recent introduction. China and East Indies.

Abundance: Uncommon.

Remarks: Planted ornamental with light red-orange flowers at the Office of the Prime Minister and the new

Tuvalu Government Building and elsewhere in the main center in 2010 and 2016.

Recorded: RRT 1991; RRT \& WAW 1993; RRT 2003; T, F \& F 2010; RRT 2016

Voucher Photographs: DPTV2500, 3525, 3526, 3771; DSC02968

Morinda citrifolia L.

Common Names: beach mulberry, Indian mulberry, noni (Hawai'i)

Tuvaluan Names: nonu (Ff, Nm, Nt; TvD); nonu Kilipati (variety with large fruit from Kiribati); te non (Nui)

Status: Indigenous or possibly an aboriginal introduction. Tropical Asia and Australia to southeastern Polynesia.

Abundance: Abundant.

Remarks: Occasional to common in houseyard gardens, neglected coconut plantations, around excavated taro pits (pela), and as an understorey species in secondary forest and in inner coastal forest on both ocean and lagoon coasts. A variegated cultivar seen at the Governor General's residence in 2010. Ripe fruit consumed raw, more commonly by older people in the past, as a known health-giving "elixir"; and now processed in many Pacific Island countries and exported as "noni" juice because of its reported curative and health-giving properties. Wood used to make rafters (oka, koso) for small buildings, boat parts, and stilts (kasaele). Leaves used as an important component of mulch or manure (kaiao) for taro gardens, in body ornamentation and chopped finely and added to coconut oil (sinu). Fruit and leaves sometimes fed to pigs. Leaves used medicinally by rubbing directly on the skin as a painkiller and in water to treat stomach ache. Inner roots scraped and mixed with lime to make a dark yellowish dye and the bark of the roots boiled in water to produce red dye, both of which are used to dye pandanus leaves used to weave multi-color mats, fans, balls and other handicrafts. Tree also important in black magic in the past (Seluka 1997; Koch 2002).

Remarks: CH 1896; JHM 1904; CW 1991; RRT 1991; RRT \& WAW 1993; SS 1997; RRT 2003; T, F \& F 2010; RRT 2016

Voucher Photographs: DPTV0610, 0819, 0825, 0924, 1054, 1147, 2113, 2114, 2408, 2409, 2711, 2712, 2713, 2714, 3466, 3467, 3542, 3543, 3609b, 3610b, 3611b, 3640, 3641, 3679, 3680

\section{Oldenlandia corymbosa $\mathrm{L}$.}

Synonym: Hedyotis corymbosa (L.) Lam.

Common Name: old world diamond flower

Status: Recent introduction. Pantropical.

Abundance: Occasional. 
Remarks: Small-leaved herb. Weed of lawns, wasteplaces and roadsides.

Recorded: RRT 2003; T, F \&F 2010; RRT 2016

Voucher Photographs: DPTV0630, 2022, 2023, 2035, 0983, 1133, 2131

Spermacoce assurgens R. \& P.

Synonyms: Spermacoce suffrutescens Jacq.; Borreria laevis sens

Common Name: buttonweed

Status: Recent introduction. South Asia.

Abundance: Locally abundant.

Recorded: Small erect herb with small white flowers. Weed in gardens, roadsides, waste places and ruderal sites.

Recorded: RRT 1991; RRT \& WAW 1993; SS 1997; RRT 2003; T, F \& F 2010; RRT 2016

Voucher Photographs: DPTV0939, 2058, 2059, 3545

Timonius polygamus (Forst. f.) Robinson

Status: Indigenous. Rennell Island in the Solomon Islands east to the Tuamotu Archipelago and most groups in between, except Samoa.

Abundance: Rare.

Remarks: Small flowering plant with four-petalled white flowers seen on Fualopa Islet in 2003. Not previously reported from Tuvalu.

Recorded: RRT 2003

Voucher Photographs: DPTV01071

\section{RUTACEAE (RUE FAMILY)}

Citrus aurantifolia (Christm.) Swingle

Synonym: Limonia aurantifolia Christm.

Common Name: lime

Tuvaluan Names: laim (Ff, Nm); laimi (Ff; Seluka 1997)

Status: Recent introduction. Malesia.

Abundance: Uncommon.

Remarks: Planted fruit tree in houseyard gardens. Reportedly much more common in the past and the citrus species that seems to grow best on atolls. Fruit used to make drinks and marinate raw fish. Juice reportedly used as a disinfectant and wood used occasionally for firewood.

Recorded: RRT 1991; RRT \& WAW 1993; SS 1997; RRT 2003; T, F \& F 2010; RRT 2016

Citrus limon (L.) Burm. f.

Synonyms: Citrus medica var. limon L.; C. limonum Risso; C. limonia Osbeck

Common Names: rough lemon, lemon

Tuvaluan Names: moli (Ff; Tvd); lemoni (Nm)

Status: Recent introduction. East Asia.

Abundance: Occasional.

Remarks: Planted fruit tree in houseyard gardens; the most common citrus on Funafuti, whereas the lime seems to be the most common on other atolls, such as in Kiribati and the Marshall Islands. Probably the species referred to by Seluka (1997) as Citrus hystrix. Juice used to make drinks, to squeeze on food, especially fish, and to marinate raw fish. Leaves boiled to make lemon-leaf tea.

Recorded: RRT 1991; RRT \& WAW 1993; SS 1997; RRT 2003; T, F \& F 2010; RRT 2016

Voucher Photographs: DPTV0954, 0955, 0956, 3708, 3709

Citrus mitis Blanco

Common Names: calamondin orange, musk lime, calamansi

Tuvaluan Name: laimi (Ff; Seluka 1997) 
Status: Recent introduction. East Asia.

Abundance: Rare.

Remarks: Planted fruit tree in the PRAP Nursery in the early 1990s and reported present by Seluka (1993). According to some authorities, Citrus mitis is a hybrid cross between a true citrus and the kumquat (Fortunella japonica), which is sometimes referred to as x Citrofortunella. An increasingly common citrus tree in Fiji and elsewhere in the Pacific Islands, where the juice is made into drinks, used to marinate fish and squeeze on food.

Recorded: RRT \& WAW 1993; SS 1997

Murray koenigii (L.) Spreng.

Common Names: curry leaf, Indian bay leaf, karipilai

Status: Recent introduction. India and Southeastern Asia.

Abundance: Rare.

Remarks: Seen planted in two houseyard gardens in 2016. Reportedly introduced from Fiji where it is commonly cultivated by Indian families. Pungent spicy young leaves used as a spice in curries and dahl (lentil) soups.

Recorded: RRT 2016

Voucher Photograph: DSC03414

\section{SANTALACEAE (SANDALWOOD FAMILY)}

Santalum yasi Seem x S. album L.

Common Name: hybrid sandalwood

Status: Recent introduction.

Abundance: Rare.

Remarks: The seedlings appear to be a hybrid cultivar between the Pacific indigenous Santalum yasi, which is indigenous from Vanuatu to Fiji and probably an aboriginal introduction to Tonga, and possibly Niue, and Indian sandalwood (S. album), which is indigenous to dry areas of the Indian subcontinent. A number of small seedlings planted for distribution were seen in 2016 in the Tuvalu Agricultural Department Nursery for utilizing climate resilient crops. The heartwood is used to scent coconut oil of the finest quality. The bark is burned as incense and mosquito repellent, and the plant has medicinal uses. The heartwood was a major export during the nineteenth century and is still exported from Fiji, Tonga, and Vanuatu, as well as being used for woodcarving for the tourist industry. Sandalwood is currently the focus of agroforestry programs in Vanuatu, Fiji and Tonga as a very high value export crop. It remains to be seen if sandalwood can withstand the harsh conditions of the atoll environment in Tuvalu.

Recorded: RRT 2016

Voucher Photographs: DSC02595, 02597

\section{SCROPHULARIACEAE (SNAPDRAGON FAMILY)}

Russelia equisetiformis Schlect. and Cham.

Common Names: firecracker flower, firecracker plant, fountain bush

Tuvaluan Name: kaipauni (from Kiribati te kaibaun; Ff, Nm)

Status: Recent introduction. Mexico.

Abundance: Uncommon.

Remarks: Shrub with drooping branches, very small leaves and small fire-cracker-like red flowers. Planted ornamental in houseyard gardens just south of Tuvalu Government Buildings. Reported from Nanumea, Vaitupu and Nukulaelae, but not from Funafuti, by Woodroffe (1991). Flowers used in head garlands

(fou) and slender stems occasionally used as fly whisks (Seluka 1997).

Recorded: CDW 1991; RRT 1991; RRT \& WAW 1993; SS 1997; RRT 2003; T, F \& F 2010

Voucher Photographs: DPTV0651, 2879, 2880, 2888 


\section{SIMAROUBACEAE (QUASSIA FAMILY)}

Soulamea amara Lam.

Common Names: soulamea, bitter tree

Tuvaluan Name: lakau kona (Seluka 1997)

Status: Recent introduction.

Abundance: Rare.

Remarks: Indo-Pacific as far east as Solomon Islands and Vanuatu in Melanesia and to the Caroline and Marshall Islands in Micronesia, where it is reported present on 13 atolls. Reported present in Tuvalu, without a location by Seluka (1997). May have been a recent introduction during the PRAP project, which had been documented by Seluka, although it is possible that it could have been present at some time in the past.

Recorded: SS 1997

\section{SOLANACEAE (NIGHTSHADE FAMILY)}

\section{Capsicum annuum L. vars.}

Synonym: Capsicum chinense Jacq.

Common Names: annual chili pepper, red pepper, habanero

Tuvaluan Names: tili, polo feū (Ff, Nm; Tvd); polo feū lasi ("large”; Ff)

Status: Recent introduction. Tropical America.

Abundance: Uncommon.

Remarks: Food plant in houseyard garden and at Vaikulagi Hotel; and seedlings in seed trays at the Agricultural Department nursery, Vaiaku and in the Taiwan ICDF Garden in 2010 and 2016. The saclike bright red chili known as the "bongo chili" in Fiji and the habanero elsewhere, is known by some authors as Capsicum chinense, even though it is originally from tropical America. Fruit is used to spice food and leaves to treat boils.

Recorded: RRT 1991; RRT \& WAW 1993; SS 1997; RRT 2003; T, F \& F 2010; RRT 2016

Voucher Photographs: DPTV2253, 2848

Capsicum annuum L. var. grossum (L.) Sendtn.

Synonym: Capsicum grossum L.; C. dulce Hort. ex Dun.

Common Names: bell pepper, sweet pepper, sweet capsicum, paprika

Tuvaluan Names: pepa (Ff, Nm ; TvD); pepa magalo (Seluka 1997)

Status: Recent introduction. Tropical America.

Abundance: Common.

Remarks: Food plant in houseyard gardens. One of the most commonly grown green vegetables as part of the UNICEF Family Food Production Programme in 2010 and in the Taiwan Farm in 2016. Fruit eaten raw in salads and cooked in stews and chop suey. Fruit and leaves also used to feed pigs and chickens. Sold weekly by the Taiwan farm to the public, hotels and restaurants.

Recorded: RRT 1991; RRT \& WAW 1993; SS 1997; RRT 2003; T, F \& F 2010; RRT 2016

Voucher Photographs: DPTV2370, 2403, 2822, 2851; DSC02612

\section{Capsicum frutescens L.}

Synonym: Capsicum minimum Roxb.

Common Names: tabasco, bird chilli, perennial chili

Tuvaluan Names: tili, polo feū, polo feū fōliki (“small”; Ff, Nm; Tvd)

Status: Recent introduction. Tropical America.

Abundance: Occasional.

Remarks: Spice plant in houseyard food gardens; in some cases, possibly naturalized. Fruit used to spice food, especially marinated raw fish. Fruits gound up and mixed with water and used as an insect 
repellent; leaves used medicinally as a poultice to treat boils; branches used as fly whisks; and the plant also reportedly used in black magic (Seluka 1997).

Recorded: RRT 1991; RRT \& WAW 1993; SS 1997; RRT 2003; T, F \& F 2010

Voucher Photograph: DPTV0934

Cestrum nocturnum L.

Common Names: night-blooming cestrum, night-blooming jasmine, queen of the night

Tuvaluan Names: fafine o te po ("lady of the night”; Ff); pula po ("night flower”; Seluka 1997)

Status: Recent introduction. West Indies.

Abundance: Uncommon.

Remarks: Planted ornamental with fragrant small white, tubular night-blooming flowers. Flowers occasionally used in head garlands (fou).

Recorded: RRT 1991; RRT \& WAW 1993; SS 1997; RRT 2003; T, F \& F 2010

Voucher Photograph: DPTV0897

Petunia hybrida Vilm.

Common Name: petunia

Status: Recent introduction. Argentina.

Abundance: Uncommon.

Remarks: Ornamental plant and pot plant in houseyard garden at the Filomena Guest House and in some houseyard gardens in 2010.

Recorded: T, F \& F 2010

Voucher Photographs: DPTV227, 2274, 2849

Physalis angulata L.

Common Names: cape gooseberry, bladderberry, ground cherry

Tuvaluan Names: pini (“bean”; Ff, Nm); matuu (Seluka 1997)

Status: Recent introduction. Tropical America.

Abundance: Common.

Remarks: Weed of gardens, wasteplaces, borders of the airstrip and ruderal sites. Reported present on Nanumea, Nui, Nukulaelae and Funafuti in the late 1980s (Woodroffe 1991). Probably listed as Physalis minima by Seluka (1997). Ripe fruit eaten, mainly by children.

Recorded: JHM 1904; RRT 1991; RRT \& WAW 1993; SS 1997; RRT 2003; T, F \& F 2010; RRT 2016

Voucher Photographs: DPTV0520, 521, 522, 2072, 2546, 2728, 3437

\section{Solanum lycopersicum L.}

Synonym: Lycopersicon esculentum Mill.

Common Name: tomato

Tuvaluan Name: tomato (Ff, Nm; TvD)

Status: Recent introduction. Tropical America.

Abundance: Occasional.

Remarks: Food plant in houseyard gardens and in the Taiwan ICDF Garden in 2010 and 2016. Ripe fruit eaten raw and cooked and sold by the Taiwan farm to the public, hotels and restaurants.

Recorded: RRT 1991; RRT \& WAW 1993; SS 1997; RRT 2003; T, F \& F 2010; RRT 2016

Voucher Photographs: DPTV2125, 2259, 2317, 2344

\section{Solanum melongena L.}

Common Names: eggplant, aubergine, brinjal

Tuvaluan Name: paigani (from the Fijian baigani, which comes from the Hindi baigan; Ff)

Status: Recent introduction. South Asia.

Abundance: Uncommon. 
Remarks: Food plant in a number of houseyard gardens on Funāfuti and in the Taiwan ICDF Garden in 2010 and 2016. Reportedly a new plant on Nanumea. Ripe fruit cooked as a vegetable. A very important vegetable among the Indian community in Fiji.

Recorded: RRT 1991; RRT \& WAW 1993; SS 1997; RRT 2003; T, F \& F 2010; RRT 2016

Voucher Photographs: DPTV2257, 2324, 2347, 2372a, 2440, 2441

\section{STERCULIACEAE (COCOA FAMILY)}

Waltheria indica L.

Synonyms: W. americana L.; W. elliptica Cav.

Common Name: waltheria

Status: Recent introduction. Tropical America, and possibly the Pacific, at least Hawai'i.

Abundance: Rare.

Remarks: Scarcely branched erect shrub with grey-green velvety toothed leaves and dense clusters of flowers with small yellow petals. Single plant seen in a Vaiaku houseyard garden in 2003. Seen by the author as an occasional weed in South Tarawa, Kiribati. Not seen in 2010.

Recorded: RRT 2003

Voucher Photograph: DPTV0553

\section{SURIANACEAE (SURIANA FAMILY)}

\section{Suriana maritima L.}

Common Name: bay cedar

Tuvaluan Names: gie, gie cool? (Woodroffe 1991); ngie (Nui; Woodroffe 1991)

Status: Indigenous. Pantropical.

Abundance: Rare?

Remarks: Erect shrub with small leaves crowded at branch ends and yellow flowers. Superficially resembles Pemphis acidula, which is known as gie, but has yellow, rather than white flowers, and a more erect, ascending appearance. Reported present by Maiden (1904) on Funafuti and on Nui, Vaitupu and Nukulaelae by Woodroffe (1991). Common plant of upper beaches and sandy areas on many Pacific atolls. Possibly still present on sandy areas some of the small uninhabited islets of Funafuti but not seen by current author.

Recorded: JHM 1904; CDW 1991

\section{TILIACEAE (LINDEN FAMILY)}

Triumfetta procumbens Forst. $\mathrm{f}$.

Common Name: beach burr

Tuvaluan Names: tolotolo (Ff, Nm; TvD); kiaou (Nui)

Status: Indigenous. Paleotropics.

Abundance: Abundant.

Remarks: Prostrate shrub with trailing stems, fleshy toothed leaves and yellow flowers. Dominant groundcover in open sandy ruderal sites and common in sandy and rocky areas on both ocean and lagoon coasts and in open areas in woodlands on uninhabited islets; a pioneer on some areas of the coral rubble rampart formed by Tropical Cyclone Bebe in 1972. Stems with leaves and flowers used in garlands worn around the head, neck, arms or wrists as body ornamentation (napenape) on Niutao for special occasions, such as canoe construction or house building, and considered by many to be the best napenape in Niutao and Vaitupu. The leaves are used to scent coconut oil (sinu), which is one of the most highly regarded perfumed oils known as sinu tolotolo that is used to make women's hair long, straight and black. Plant used as manure (kaiao) in taro pit gardens and other gardens (Koch 2002). Leaves and stems also important medicinally, especially for women, perhaps learned from the I Kiribati. Plant also used in black magic (Seluka 1997). 
Recorded: CH 1896; JHM 1904; RRT 1991; RRT \& WAW 1993; SS 1997; RRT 2003; T, F \& F 2010; RRT 2016

Voucher Photographs: DPTV0612, 0801, 2160, 2727, 2854, 2887, 3088, 3089, 3106, 3161

\section{TURNERACEAE (TURNERA FAMILY)}

\section{Turnera ulmifolia L.}

Common Names: yellow alder, sage rose, Marilopez, West Indian holly

Tuvaluan Name: lakau pula sega (“yellow-flowered plant”; Ff)

Status: Recent introduction. Mexico and the Caribbean to northern South America.

Abundance: Occasional.

Remarks: Planted ornamental with bright yellow flowers in houseyard gardens. First seen in 2003. A recent introduction, probably in the late 1990s, possibly from Nauru or Kiribati, where it has become somewhat naturalized since the early 2000s. Flowers used in head garlands (fou) and by females as sei worn over the ear or in the hair.

Recorded: RRT 2003; T, F \& F 2010; RRT 2016

Voucher Photographs: DPTV0642, 0961, 0962, 0963, 0964, 1180b, 2102, 2358, 2386, 3499, 3500, 3501

\section{URTICACEAE (NETTLE FAMILY)}

Laportea interrupta (L.) Chew

Synonyms: Urtica interrupta L.; Fleurya spicata Gaud.; Fleurya interrupta Wight

Common Name: Hawai'i woodnettle

Tuvaluan Names: aluna (Nm; Chambers 1984); luna (Nui; Woodroffe 1991)

Status: Indigenous.

Abundance: Rare or extirpated.

Remarks: Probably native to Southeast Asia but now widespread from Africa to China, Japan and Queensland and into the Pacific Islands as far east as Hawai'i and probably an aboriginal introduction within most of its Pacific range. Reported present on Nui by Woodroffe (1991) but not reported from the other atolls.

Recorded: CDW 1991

Laportea ruderalis (Forst. f.) Chew

Synonyms: Urtica ruderalis Forst. f.; Fleurya ruderalis (Forst. f.) Gaud. ex Wedd.

Common Name: weedy woodnettle

Tuvaluan Names: luna (Ff, Nm, Nt; Tvd); luna lanu lau niu ("green”; Ff, Nm); luna lanu kula ("red”; Ff, Nm); aluna (Nm; Chambers 1984; Seluka 1997); pakisikisi

Status: Indigenous. Malayo-Pacific.

Abundance: Occasional.

Remarks: Erect herb with toothed, green to reddish-green leaves. Locally common in shady and moist disturbed sites on rocky limestone soils and in coconut woodland. Locally common in inland sites on Fualopa Islets and on the west end of Tepuka Islet near a te puka (Pisonia grandis) grove in association with Asplenium nidus. Reported present on Funafuti in 1898 by Maiden (1904) and from Nanumea and Vaitupu (Woodroffe 1991) and Niutao (Koch 2002). Used medicinally to treat stomach ache and mouth and tooth infections (Koch 2002) and as mulch or compost.

Recorded: JHM 1904; CDW 1991; RRT 1991 (24311); RRT \& WAW 1993 (24162); SS 1997; RRT 2003; T, F \& F 2010

Voucher Photographs: DPTV0744, 0745, 3226, 3227, 3228, 3229, 3230, 3237, 3242

Pilea microphylla (L.) Liebm.

Synonyms: Parietaria microphylla L.; Pilea muscosa Lindl.

Common Name: artillery plant 
Tuvaluan Names: mouku vao (Ff); lakau paula (Seluka 1997)

Status: Recent introduction. Tropical America.

Abundance: Common.

Remarks: Weed in pot plants, under planted ornamentals and on cement steps, walls and coral blocks in moist, shady sites. Reported present from Funafuti, Nanumea, Nui, Vaitupu and Nukulaelae in Woodroffe (1991). Seluka (1997) reports that the plant is used medicinally for undisclosed purposes.

Recorded: CDW 1991; RRT 1991; SS 1997; RRT \& WAW 1993; RRT 2003; T, F \& F 2010; RRT 2016

Voucher Photographs: DPTV0886, 2046, 2047, 2118

Pipturus argenteus (Forst. f.) Wedd. var. argenteus

Common Names: false stinger, white nettle, native mulberry, white mulberry

Tuvaluan Names: fou tagata (Ff); fau vau (Nm); te pau (Nui; Woodroffe 1991); fau (Nm; Chambers 1984); lafau (Nt; Koch 2002); fau pa (Nt; Koch 2002)

Status: Indigenous. Malaysia to Polynesia and Micronesia.

Abundance: Locally common.

Remarks: Shrub or small tree in neglected coconut plantations and in roadside vegetation on most of the south end of Fogafale Islet; occasional near giant swamp taro (pulaka) pits and elsewhere in disturbed sites. Common in inland sites on Tepuka and Fualopa Islets. Reported by present on all atolls in Tuvalu except Niutao and Nukulaelae, but probably also present and formerly abundant on Niutao but mistakenly identified by Koch (2002) as Ochrosia parviflorus. Leaves used as fertilizer (kaiao) in taro and banana gardens. Koch (2002) reports that in former times lafau grew all over Niutao until most were felled to obtain green manure for pulaka (Cyrtosperma) gardens. Before the introduction of rope, the strong inner bark or bast fiber was scraped using seashells or coconut shell, washed in sea water, dried and braided into cord to make the strongest fishing lines (uka), fish-hook lines (lavasi) and fish nets and to tie shafts onto tool heads and to tie-up bundles of sweet smelling flowers and leaves (manogi) used for ear ornamentation. The leaves, after singing them over fire, are woven into waist garlands (titi) on Nanumea. The fiber was probably also used in the past for loin cloths and other clothing. Also reportedly used for undisclosed medicinal purposes. Small seeds eaten when ripe as a tasty snack food (Koch 2002).

Recorded: JHM 1904; RRT 1991; RRT \& WAW 1993; RRT 2003; T, F \& F 2010; RRT 2016

Voucher Photographs: DPTV0695, 0756, 0757, 0850, 2881, 2928, 2929, 3233

Procris pedunculata (Forst.) Wedd.

Common Name: procris

Tuvaluan Name: vauvau (Nkl; Woodroffe 1991)

Status: Indigenous. Malesia, and possibly tropical Asia, to the Marquesas and Tuamotus in Eastern Polynesia.

Abundance: Rare.

Remarks: Small succulent subshrub, often found on limestone. Reported from Nukulaelae by Woodroffe (1991) but from no other atolls in Tuvalu.

Recorded: CDW 1991

\section{VERBENACEAE (VERBENA FAMILY)}

\section{Clerodendrum inerme L.}

Common Name: beach privet

Tuvaluan Name: inato (from the Kiribati te inato; Ff, Nm, Nui; TvD)

Status: Indigenous. Indomalaysia, Australia and the Pacific Islands, but possibly introduced to, or extirpated on Funafuti where it is no longer found growing wild.

Abundance: Occasional.

Remarks: A scandent or arching shrub with small white flowers. Planted ornamental or hedge plant in houseyard gardens and occasional near excavated taro pit gardens (pela) on Funafuti. Reported present 
on Nanumaga, Nui, Vaitupu and Niulakita, but not from Funafuti, in Woodroffe (1991). Rare in undisturbed vegetation, but probably more common in the past. The flowers are used in garlands and the young leaves used to scent coconut oil known as sinu inato (Seluka 1997). The plant is also used medicinally, especially to treat children's cuts and wounds. In Kiribati the leaves are boiled to produce a brown dye to color pandanus and coconut leaves and the pliable wood and stems are used to make frames for nets, shark rattles and sieves (Koch 2002).

Recorded: RRT 1991; RRT \& WAW 1993; SS 1997; RRT 2003; T, F \& F 2010; RRT 2016

Voucher Photographs: DPTV0945, 0946, 2203, 2675, 2676, 3450, 3451, 3452, 3453, 3454

\section{Duranta erecta L.}

Synonym: Duranta repens L.

Common Names: golden dewdrops, golden eardrops

Status: Recent introduction. Tropical America.

Abundance: Occasional.

Remarks: Erect shrub with yellowish-green leaves, light blue flowers and small hanging orange fruits that are said to be lightly poisonous. Planted ornamental in the Tuvalu Government Building garden and in some houseyard gardens. One of the fastest spreading ornamental and hedge plants in the Pacific Islands, which is replacing traditional ornamentals and other useful plants in many areas.

Recorded: T, F \& F 2010; RRT 2016

Voucher Photographs: DPTV2498, 2842, 3710, 3711, 3726a

\section{Lantana camara L.}

Common Name: lantana

Tuvaluan Name: kaipuaka (from the Kiribati te kai buaka; Ff, Nm)

Status: Recent introduction. Tropical America.

Abundance: Occasional.

Remarks: Planted ornamental in houseyard gardens and landscaping. Possibly an introduction via Kiribati, from either Banaba or Nauru. Not reported present by Woodroffe (1991). Planted ornamental, sometimes as a component of hedges. Flowers used in head garlands (fou) or worn by females as sei over the ear or in the hair, often by young girls. Reported to be an insect repellent by Seluka (1997).

Recorded: RRT 1991; RRT \& WAW 1993; SS 1997; RRT 2003; T, F \& F 2010; RRT 2016

Voucher Photographs: DPTV0645, 0879, 2061, 2062, 3515, 3664, 3665

\section{Premna serratifolia L.}

Synonyms: Premna obtusifolia R. Br.; P. gaudichaudii Schauer; P. integrifolia L.; P. taitensis Schauer; $P$. corymbosa (Burm. f.) Rottl. \& Willd.; P. alba Lam.

Common Names: false elderberry, headache tree

Tuvaluan Names: valovalo (Ff; Tvd); aloalo (Nm, Vt; TvD); te ango (Nui)

Status: Indigenous. Indopacific.

Abundance: Common.

Remarks: Occasional tree or shrub in coastal vegetation; a common pioneer in abandoned coconut plantations and secondary vegetation and occasional in houseyard gardens, often as a component of hedges. Strong wood used to make house posts (pou), drums (pate), cooking stands, fishing rods (velo), breadfruitpicking poles (lou) and clamps and clothes pins. Greenish-white flowers and young leaves used in head and waist garlands (fou and titi). The leaves and roots are used medicinally to treat headaches; leaves used for scenting coconut oil; and the wood favored for making fire by friction in the past. One of the Pacific's more widely used medicinal plants.

Recorded: CH 1896; JHM 1904; CDW 1991; RRT 1991; RRT \& WAW 1993; SS 1997; RRT 2003; T, F \& F 2010; RRT 2016

Voucher Photographs: DPTV0608, 0925, 1172, 2709 
Stachytarpheta cayennensis (Ruioz \& Pavon) Vahl

Synonyms: Stachytarpheta urticaefolia Sims; Cymburus urticaefolius Salisb.

Common Names: blue rat's tail, false verbena

Tuvaluan Name: lakau pakēkē (Ff)

Status: Recent introduction. Tropical America.

Abundance: Rare.

Remarks: Branching subshrub with toothed, bright-green leaves and terminal flower spikes with blue flowers. Weed or protected ornamental seen along the roadside in Vaiakufou, South Fogafale Islet in 2003, but not seen in 2010 or 2016.

Recorded: RRT 1991; RRT \& WAW 1993; RRT 2003

Voucher Photographs: DPTV0614, 0615, 0616, 0621a, 0622a

Stachytarpheta jamaicensis (L.) Vahl

Synonyms: Verbena jamaicensis L.; Stachytarpheta indica (L.) Vahl

Common Name: Jamaica vervain

Tuvaluan Name: lakau pakēkē (Ff)

Status: Recent introduction. Tropical America.

Abundance: Common.

Remarks: Erect, but low or procumbent subshrub with toothed shiny green leaves and terminal flower spikes with pale-blue flowers. Weed of roadsides, waste places, the borders of the airfield and other ruderal sites. Similar in appearance to $S$. cayennensis, but lower growing and with more fleshy, somewhat shiny or metallic looking leaves.

Recorded: RRT 1991; RRT \& WAW 1993; RRT 2003; T, F \& F 2010; RRT 2016

Voucher Photographs: DPTV0619, 0620, 0621b, 0622b,1157, 2292, 2464, 2465, 2466, 2487, 2534, 2918

Vitex trifolia L. var. bicolor (Lam) Mold.

Synonym: Vitex negundo L. var. bicolor (Willd.) H. J. Lam

Common Name: blue vitex

Tuvaluan Names: lakau tā namu ("plant that kills mosquitos"; Ff); kanamunamu (from the Marshallese wut kanamunam; Ff)

Status: Recent introduction. East Africa to the Pacific Islands east to all of the major archipelagos of Micronesia and to the Marquesas.

Abundance: Uncommon.

Remarks: Although possibly present in the long distant past, maybe in association with mangroves, it is probably a deliberate introduction from either Nauru, Banaba or the Marshall Islands, the latter where it is planted as a mosquito-repellent hedge. Seen in a couple of houseyard gardens in Fogafale and in one salt-damaged stand on the inner summit of the coral rubble rampart on the coast near small rubbish dump near the pig rearing area to the northeast of the airstrip in 2010 and on the margins of the infilled reclaimed borrow pits in 2016. Not listed as present from any of the atolls of Tuvalu in Woodroffe (1991). Planted as a hedge because of its mosquito repellent properties. Leaves also reportedly burned to repel mosquitoes. An important medicinal plant in Samoa and Tonga and Fiji.

Recorded: RRT 2003; T, F \& F 2010; RRT 2016

Voucher Photographs: DPTV0679, 1145, 2199, 2200, 2418, 2620, 2630, 2632, 2633, 2634, 2638b, 3567, 3568, 3569, 3570, 3571, 3572

\section{VITACEAE (GRAPE FAMILY)}

Vitis sp.

Common Name: grape

Tuvaluan Names: vine, vine mata (TvD)

Status: Recent introduction. Europe or North America.

Abundance: Uncommon. 
Remarks: Single plants in bank garden and in PRAP experimental garden in 2003. Two plants seen in the Taiwan ICDF Garden in 2010.

Recorded: RRT 2003; T, F \& F 2010

Voucher Photographs: DPTV1030b, 1158, 2427

\section{ACKNOWLEDGMENTS}

Over the past 25 years many people have assisted in this work and shared their friendship, hospitality and knowledge of Tuvalu's plants. These include the main informants in Tuvalu, Ioasa Tilaima, Vevea Tepou, Kamuta Latasi, Ela Sam Panapa and Make Pita, as well as Eliala Fihaki, Teddy Fong and Semese Alefaio, who have assisted with this study and have coauthored with me books on plants and fishes of Tuvalu. Special thanks are owed to Art Whistler, the Pacific Islands' foremost botanist and ethnobotanist, who carried out fieldwork with me in Tuvalu in 1992 as a basis for a book on trees in agricultural systems in Tonga, Samoa, Tuvalu and Kiribati.

Others who have shared their knowledge and hospitality and facilitated the study of Tuvalu's plants over the years have included former Prime Ministers and their wives, Kamuta and Naama Latasi, Bikenibeu and Foketi Paeniu and Saufatu and Filifau Sopoaga, as well as Siliga Kofe, Mataio Tekenene, Enate Evi, Lotoala and Penieli Metia, Sam Finekaso, Eti Esela, Paani Laupepa and Feleti Teo. Thanks also to the organizations that have supported this work over the years. They include the University of the South Pacific (USP), the Secretariat of the Pacific Regional Environment Programme (SPREP), the Forest and Trees Programme of the Secretariat of the Pacific Community (SPC) and the Food and Agricultural Organization (FAO) of the United Nations.

To others who helped in any way I also give thanks and sincerely apologize for failing to mention you by name. I also apologize for any inaccuracies or omissions.

Finally, I wish to express my heartfelt thanks to the people of Tuvalu, whose warmth and hospitality have made working in their beautiful but damaged and vulnerable atoll nation so enjoyable and worthwhile.

To all of you, fakafetai lasi

Randy Thaman

Suva, Fiji

April 2016 


\section{APPENDIX: \\ CHECKLISTS OF INDIGENOUS AND ABORIGINAL PLANTS OF TUVALU}

Table A1. Indigenous or possibly indigenous plants of Tuvalu. A question mark (?) indicates uncertainty: for species, the status could be indigenous either now or originally at some time in the past but has become locally extinct/extirpated, or the status could be an aboriginal introduction from another Pacific island where it is indigenous; for names, based on the current study, the name of the plant is doubtful.

\begin{tabular}{|c|c|c|}
\hline Species & Common Name(s) & Tuvaluan Name(s) \\
\hline \multicolumn{3}{|c|}{ PTERIDOPHYTA (FERNS AND FERN ALLIES) } \\
\hline \multicolumn{3}{|c|}{ ASPLENIACEAE (SPLEENWORT FERN FAMILY) } \\
\hline Asplenium nidus L. & bird's-nest fern & katafa, laukatafa, laulū \\
\hline \multicolumn{3}{|c|}{ NEPHROLEPIDACEAE (SWORD FERN FAMILY) } \\
\hline $\begin{array}{l}\text { Nephrolepis acutifolia (Desv.) } \\
\text { Christ }\end{array}$ & sword fern, fishtail fern & sulufe, hulufe, paka, laukimoa \\
\hline $\begin{array}{l}\text { Nephrolepis hirsutula (Forst. f.) } \\
\text { Presl }\end{array}$ & sword fern, fishtail fern & sulufe \\
\hline \multicolumn{3}{|c|}{ POLYPODIACEAE (COMMON OR POLYPODY FERN FAMILY) } \\
\hline $\begin{array}{l}\text { Microsorum grossum (Langsd. \& } \\
\text { Fisch.) S.B. Andrews } \\
\end{array}$ & scented fern, lawai fern & maile \\
\hline \multicolumn{3}{|c|}{ Psilotaceae (Psilotum FAMily) } \\
\hline Psilotum nudum (L.) Beauv. & psilotum, reed fern & sai, pōatua, silotau, fulukimoa \\
\hline
\end{tabular}

PTERIDACEAE (BRACKEN OR BRAKE FERN FAMILY)

Pteris tripartita Sw. $\quad$ lacy fern, giant bracken fern, lautolo, lakau sauga? sword brake

ANGIOSPERMAE (ANGIOSPERMS)

MONOCOTYLEDONAE (MONOCOTYLEDONS)

Arecaceae (Palmae) (Palm Family)

Cocos nucifera L. ?

coconut palm

niu, niu Fiti

CYPERACEAE (SEDGE FAMILY)

Eleocharis geniculata (L.) Roem. sedge

none reported

$\&$ Schultes?

Fimbristylis cymosa R. Br.

sedge, beach sedge

mouku milimili taliga

Mariscus javanicus (Houtt.) Merr. $\quad$ sedge, marsh cypress

mouku filifou, mouku, lakau fai tika

PANDANACEAE (PANDANUS FAMILY)

Pandanus tectorius Warb. pandanus, screw pine

fala, fala vao, fala tinakaleve, kie, falaketi, fala kai

POACEAE OR GRAMinaE (GRASS FAMILy)

Ischaemum murinum G. Forst.

ribbed muraina grass

mouku

Lepturopetium kuniense Morat.

none reported

mouku

(continued) 
Table A1. Indigenous or possibly indigenous plants of Tuvalu. (continued)

\begin{tabular}{|c|c|c|}
\hline Species & Common Name(s) & Tuvaluan Name(s) \\
\hline \multicolumn{3}{|c|}{ POACEAE OR GRAMINAE (GRASS FAMILY) (continued) } \\
\hline Lepturus repens (Forst. f.) R. Br. & bunchgrass, beach bunchgrass & $\begin{array}{l}\text { mouku, mouku lauliliki te titi o } \\
\text { Kulu, mutia }\end{array}$ \\
\hline Paspalum vaginatum Sw. & $\begin{array}{l}\text { knot grass, salt grass, } \\
\text { knotweed, swamp couch grass }\end{array}$ & mouku \\
\hline $\begin{array}{l}\text { Stenotaphrum micranthum (Desv.) } \\
\text { Hubb. }\end{array}$ & none reported & $\begin{array}{l}\text { mouku, mouku lauliliki te titi o } \\
\text { Kulu }\end{array}$ \\
\hline $\begin{array}{l}\text { Thuarea involuta (Forst. f.) R. Br. } \\
\text { ex R. \& S. }\end{array}$ & $\begin{array}{l}\text { Tropical beachgrass, Kuroiwa } \\
\text { grass }\end{array}$ & $\begin{array}{l}\text { mouku solo, mouku tolo, } \\
\text { mouku fau }\end{array}$ \\
\hline
\end{tabular}

\section{DICOTYLEDONAE (DICOTYLEDONS)}

AMARANTHACEAE (AMARANTH FAMILY)

Achyranthes canescens R. Br. native prickly chaff-flower tamatama, lautamatama, sisi vau

APOCYNACEAE (DOG-BANE FAMILY)

Neisosperma oppositifolium (Lam.) none reported fao, paopao, paupau

Fosb. \& Sachet

ASTERACEAE (ASTER, SUNFLOWER OR COMPOSITE FAMILY)

\begin{tabular}{|c|c|c|}
\hline $\begin{array}{l}\text { Adenostemma lanceolatum Miq.? } \\
\text { Wollastonia biflora (L.) DC. }\end{array}$ & $\begin{array}{l}\text { Adenostema } \\
\text { beach sunflower }\end{array}$ & $\begin{array}{l}\text { mili, lipilipi, kisikisi? } \\
\text { ateate, lakau o galiga, lakau }\end{array}$ \\
\hline
\end{tabular}

BARRINGTONIACEAE OR LECYTHIDACEAE (BRAZILNUT FAMILY)

Barringtonia asiatica (L.) Kurz. $\quad$ fish-poison tree, barringtonia futu, kafutu, kafuti, ulu

BORAGINACEAE (HELIOTROPE FAMILY)

Cordia subcordata Lam.

Tournefortia argentea L. f. beach heliotrope tausunu, tauhunu

ClUSIACEAE OR GUTTIFERAE (MANGOSTEEN FAMILY)

Calophyllum inophyllum L. $\quad$ Portia tree, Alexandrian laurel, fetau, itati beach mahogany, tomano

(Hawaii)

\section{COMBRETACEAE (TERMINALIA FAMILY)}

$\begin{array}{lll}\text { Lumnitzera littorea (Jack) Voigt } & \begin{array}{l}\text { red-flowered black mangrove } \\ \text { berminalia samoensis Rech. }\end{array} & \begin{array}{l}\text { tokotū, sagale, hagale, tangali } \\ \text { talie, te ipe }\end{array}\end{array}$

CONVOLVUlaCEAE (MORNING-GLORY FAMILY)

Ipomoea macrantha R. \& S. $\quad$ wild moon flower, night- $\quad$ fue, fue kena, fue pula kena, blooming beach morning-glory fue, fue tolo

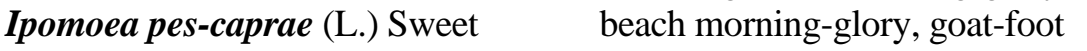
morning-glory

EUPHORBIACEAE (SPURGE FAMILY)

Acalypha grandis Benth. $\quad$ Acalypha

Chamaesyce atoto (Forst. f) Croizat beach spurge fue, fue piniki, fue pula piniki

ogoogo, kalakalāpuhi, kalakalāpuki?, kakarapus mouku toto, eveeve, pulutai

(continued) 
Table A1. Indigenous or possibly indigenous plants of Tuvalu. (continued)

\begin{tabular}{|c|c|c|}
\hline Species & Common Name(s) & Tuvaluan Name(s) \\
\hline \multicolumn{3}{|c|}{ FABACEAE OR LEGUMINOSAE (BEAN, PEA OR LEGUME FAMILY) } \\
\hline Caesalpinia bonduc Roxb. & $\begin{array}{l}\text { beach nicker, gray nicker, } \\
\text { nicker bean }\end{array}$ & talatalāmoa? \\
\hline Canavalia cathartica Thou. & Mauna Loa bean (Hawaii) & saketa \\
\hline$\overline{\text { Mucuna gigantea (Willd.) DC. }}$ & $\begin{array}{l}\text { seabean, giant seabean, velvet } \\
\text { bean }\end{array}$ & saketa \\
\hline Sophora tomentosa L. & Silverbush & none reported \\
\hline Vigna marina (Burm.) Merr. & beach pea & saketa, saketa sama \\
\hline \multicolumn{3}{|c|}{ GOODENIACEAE (NAUPAKA FAMILY) } \\
\hline Scaevola taccada (Gaertn.) Roxb. & half-flower, beach saltbush & gasu, gahu \\
\hline \multicolumn{3}{|c|}{ HERNANDIACEAE (HERNANDIA FAMILY) } \\
\hline $\begin{array}{l}\text { Hernandia nymphaeifolia (Presl.) } \\
\text { Kubitzki }\end{array}$ & hernandia, lantern tree & $\begin{array}{l}\text { puka, puka vaka, puka vai, puka } \\
\text { faivaka }\end{array}$ \\
\hline \multicolumn{3}{|c|}{ LAURACEAE (LAUREL FAMILY) } \\
\hline Cassytha filiformis L. & $\begin{array}{l}\text { beach dodder, giant dodder, } \\
\text { devil's twine }\end{array}$ & fetai \\
\hline \multicolumn{3}{|c|}{ LYTHRACEAE (LOOSESTRIFE FAMILY) } \\
\hline Pemphis acidula J.R. \& G. Forst & pemphis, ironwood & gie, giegie \\
\hline \multicolumn{3}{|c|}{$\begin{array}{l}\text { MALVACEAE (MALLOW FAMILY) } \\
\text { MAL }\end{array}$} \\
\hline Abutilon indicum (L.) Sweet & Indian mallow & aka tā \\
\hline$\overline{\text { Hibiscus tiliaceus L. }}$ & beach hibiscus, hibiscus tree & $\begin{array}{l}\text { fou, fou, fou fafine, fau, fau tuu, } \\
\text { fau tuu, fau tū }\end{array}$ \\
\hline Sida fallax Walp. & $\begin{array}{l}\text { golden mallow, ilima (Hawaii), } \\
\text { te kaura (Kiribati) }\end{array}$ & akatā, kai ‘uli, kaula \\
\hline $\begin{array}{l}\text { Thespesia populnea (L.) Sol. ex } \\
\text { Correa }\end{array}$ & $\begin{array}{l}\text { Thespian’s tree, milo (Hawaii, } \\
\text { Polynesia) }\end{array}$ & milo \\
\hline \multicolumn{3}{|c|}{ MORACEAE (MULBERRY FAMILY) } \\
\hline Ficus tinctoria Forst. f. & Dyer's fig, native fig & $\begin{array}{l}\text { felo, felo lasi, felo fōliki, felo, } \\
\text { felo Nanumaga, pelo }\end{array}$ \\
\hline \multicolumn{3}{|c|}{ NYCTAGINACEAE (FOUR-O'CLOCK FAMILY) } \\
\hline Boerhavia repens L. ? & boerhavia, pigweed & $\begin{array}{l}\text { mouku solo, mouku tolo, kalisi- } \\
\text { lisi, kisi }\end{array}$ \\
\hline Boerhavia tetrandra Forst. f. & none reported & $\begin{array}{l}\text { kisikisi, kalihilihi, eveeve } \\
\text { lauefa }\end{array}$ \\
\hline Pisonia grandis R. Brown & $\begin{array}{l}\text { pisonia, lettuce tree, bird- } \\
\text { catcher tree }\end{array}$ & puka, pukavai, puka fai kaiao \\
\hline \multicolumn{3}{|c|}{ OLACACEAE (OLAX FAMILY) } \\
\hline Ximenia americana L. & none reported & talatalāmoa, kanana \\
\hline \multicolumn{3}{|c|}{ Portulacaceae (PURSLANe Family) } \\
\hline Portulaca australis Endl. & small-leaf portulaca & katuli, tuli \\
\hline Portulaca lutea Solander ex Forst. f. & Purslane & katuli \\
\hline \multicolumn{3}{|c|}{ RHAMNACEAE (BUCKTHORN FAMILY) } \\
\hline Colubrina asiatica (L.) Brongn. & soapbush, hoop with/hoop-withe & lakau sopu, lakau hopu \\
\hline
\end{tabular}

(continued) 
Table A1. Indigenous or possibly indigenous plants of Tuvalu. (continued)

\begin{tabular}{|c|c|c|}
\hline Species & Common Name(s) & Tuvaluan Name(s) \\
\hline \multicolumn{3}{|c|}{ RHIZOPHORACEAE (MANGROVE FAMILY) } \\
\hline Rhizophora stylosa Griff. & spotted mangrove & togo, te tongo, pika \\
\hline \multicolumn{3}{|c|}{ RUBIACEAE (COFFEE FAMILY) } \\
\hline Guettarda speciosa L. & $\begin{array}{l}\text { beach gardenia, sea randa, zebra } \\
\text { wood }\end{array}$ & pua, pua vao, uli \\
\hline $\begin{array}{l}\text { Hedyotis romanzoffiensis (C \& S) } \\
\text { Fosb. }\end{array}$ & none reported & none reported \\
\hline$\overline{\text { Morinda citrifolia } \mathrm{L} .}$ & $\begin{array}{l}\text { beach mulberry, Indian } \\
\text { mulberry, noni (Hawaii) }\end{array}$ & nonu, nonu Kilipati, te non \\
\hline $\begin{array}{l}\text { Timonius polygamus (Forst. f.) } \\
\text { Robinson }\end{array}$ & none reported & none reported \\
\hline \multicolumn{3}{|c|}{ SURIANACEAE (QUASSIA FAMILY) } \\
\hline Suriana maritima L. & bay cedar & gie, gie cool?, ngie \\
\hline & ILIACEAE (LINDEN FAMILY) & \\
\hline Triumfetta procumbens Forst. f. & beach burr & tolotolo, kiaou \\
\hline \multicolumn{3}{|c|}{ URTICACEAE (NETTLE FAMILY) } \\
\hline $\begin{array}{l}\text { Laportea interrupta (L.) Chew } \\
\text { Laportea ruderalis (Forst. f.) Chew }\end{array}$ & $\begin{array}{l}\text { Hawaii woodnettle } \\
\text { weedy woodnettle }\end{array}$ & $\begin{array}{l}\text { aluna, luna } \\
\text { luna, luna lanu lau niu, luna } \\
\text { lanu kula, aluna, pakisikisi }\end{array}$ \\
\hline $\begin{array}{l}\text { Pipturus argenteus (Forst. f.) Wedd. } \\
\text { var. argenteus }\end{array}$ & $\begin{array}{l}\text { false stinger, white nettle, } \\
\text { native mulberry, white }\end{array}$ & $\begin{array}{l}\text { fou tagata, fau vau, te pau, fau, } \\
\text { la fau, fau pa, pau pau }\end{array}$ \\
\hline Procris pedunculata (Forst.) Wedd. & Procris & vauvau \\
\hline \multicolumn{3}{|c|}{ VERBENACEAE (VERBENA FAMILY) } \\
\hline $\begin{array}{l}\text { Clerodendrum inerme L. } \\
\text { Premna serratifolia L. }\end{array}$ & $\begin{array}{l}\text { beach privet } \\
\text { false elderberry, headache tree }\end{array}$ & $\begin{array}{l}\text { inato } \\
\text { valovalo, aloalo, te ango }\end{array}$ \\
\hline
\end{tabular}


Table A.2. Plants of possible aboriginal origin found in Tuvalu (i.e., non-indigenous plants assumed to have been introduced into Tuvalu by Tuvaluans or other Pacific Islanders sometime before European contact). A question mark (?) indicates uncertainty: for species, the status could be either an aboriginal introduction that is now rare or extirpated, or a recent introduction; for names, based on the current study, the name of the plant is doubtful. An asterisk $\left(^{*}\right)$ indicates a species that could also be indigenous and is listed in Table A.1 above but is also represented by varieties or cultivars introduced by Tuvaluans or Marshallese or other Pacific Islanders. There are undoubtedly other aboriginally introduced weeds that may now be considered to be indigenous or classified as post-European contact introductions.

\begin{tabular}{|c|c|c|}
\hline Species & Common Name(s) & Tuvaluan Name(s) \\
\hline \multicolumn{3}{|c|}{ ANGIOSPERMAE (ANGIOSPERMS) } \\
\hline \multicolumn{3}{|c|}{ MONOCOTYLEDONAE (MONOCOTYLEDONS) } \\
\hline $\begin{array}{l}\text { Alocasia macrorrhiza (L.) Schott } \\
\text { Colocasia esculenta L. } \\
\text { Cyrtosperma chamissonis (Schott) } \\
\text { Merr. }\end{array}$ & $\begin{array}{l}\text { ARACEAE (ARUM FAMILY) } \\
\text { giant taro, elephant ears } \\
\text { Taro } \\
\text { giant swamp taro }\end{array}$ & $\begin{array}{l}\text { tāmū, kape } \\
\text { talo } \\
\text { pulaka }\end{array}$ \\
\hline \multicolumn{3}{|c|}{ ARECACEAE (PALMAE) (PALM FAMILY) } \\
\hline Cocos nucifera L.* & coconut palm & niu, niu Fiti \\
\hline \multicolumn{3}{|c|}{ MUSACEAE (BANANA FAMILY) } \\
\hline Musa (ABB Group) Simmonds & $\begin{array}{l}\text { cooking banana, plantain, } \\
\text { bluggoe }\end{array}$ & pata \\
\hline Musa (ABB Group) Simmonds & $\begin{array}{l}\text { cooking banana, plantain, blue } \\
\text { Java }\end{array}$ & kefu \\
\hline \multicolumn{3}{|c|}{ PANDANACEAE (PANDANUS FAMILY) } \\
\hline Pandanus tectorius Warb.* & pandanus, screw pine & $\begin{array}{l}\text { fala, fala vao, fala tinakaleve, } \\
\text { kie, falaketi, fala kai, teou, te to }\end{array}$ \\
\hline \multicolumn{3}{|c|}{ TACCACEAE (Polynesian ARRoWroot FAMILY) } \\
\hline $\begin{array}{l}\text { Tacca leontopetaloides (L.) O. } \\
\text { Kuntze } \\
\end{array}$ & Polynesian arrowroot & vatia, masoā, niu ‘a Naleau \\
\hline \multicolumn{3}{|c|}{ DICOTYLEDONAE (DICOTYLEDONS) } \\
\hline \multicolumn{3}{|c|}{ AMARANTHACEAE (AMARANTH FAMILY) } \\
\hline Achyranthes aspera L. & prickly chaff flower & tamatama, titi vau, sisi vau \\
\hline \multicolumn{3}{|c|}{ APIACEAE (PARSLEY FAMILY) } \\
\hline Centella asiatica (L.) Urban ? & Asiatic pennywort & none reported \\
\hline \multicolumn{3}{|c|}{$\begin{array}{ll}\text { COMBRETACEAE (TERMINALIA FAMILY) } \\
\text { COMR }\end{array}$} \\
\hline Terminalia catappa L. ? & $\begin{array}{l}\text { Indian almond, Malabar } \\
\text { almond, tropical almond }\end{array}$ & kunikuni \\
\hline \multicolumn{3}{|c|}{ MORACEAE (MULBERRY FAMILY) } \\
\hline Artocarpus altilis (Park.) Fosb. & breadfruit & mei \\
\hline Artocarpus mariannensis Trec. & Marianas breadfruit & mei, pokēkē, matua mei? \\
\hline \multicolumn{3}{|c|}{ RUBIACEAE (COFFEE FAMILY) } \\
\hline Gardenia taitensis DC. ? & $\begin{array}{l}\text { Tahitian gardenia, tiare Tahiti } \\
\text { (Tahiti) }\end{array}$ & tiale, siale \\
\hline
\end{tabular}




\section{REFERENCES}

Bellwood, P. 1987. The Polynesians: Prehistory of an Island People. New York: Thames and Hudson. Bryan, E. H., Jr. 1953. Check List of Atolls. Atoll Research Bulletin, 19:1-38.

- 1972. Life in the Marshall Islands. Honolulu: Pacific Science Information Center, Bernice P. Bishop Museum, Honolulu.

Carter, J., ed. 1984. Pacific Islands Yearbook. 15th edition. Sydney: Pacific Publications.

Chambers, A. 1984. "Nanumea.” Atoll Economy: Social Change in Kiribati and Tuvalu, no. 6. Canberra: Australian National University.

Chase, A. R. 1986. Comparisons of Three Bacterial Leaf Spots of Hibiscus rosa-sinensis. Plant Disease, 70(4):334-336.

Country Meters. 2016. “Tuvalu population.” http://countrymeters.info/en/Tuvalu (accessed March 30, 2016).

David, E., Mrs. 1899. Funafuti or Three Months on a Coral Atoll: An Unscientific Account of a Scientific Expedition. London: John Murray.

Douglas, N., and N. Douglas, eds. 1989. Pacific Islands Yearbook. 16th ed. Sydney: Angus and Robertson Publishers.

Fosberg, F. R. 1949. Atoll Vegetation and Salinity. Pacific Science, 3:89-92.

Friday, J. B., and D. Okano. 2006. “Cordia subcordata (kou): Boraginaceae (Borage Family).” In Traditional Trees of Pacific Islands: Their Culture, Environment, and Use, ed. C. R. Elevitch, pp. 303-310. Holualoa, Hawai'i: Permanent Agriculture Resources.

Fitchett, K. 1987. Physical Effects of Hurricane Bebe upon Funafuti Atoll, Tuvalu. Australian Geographer, 18:1-7.

Goldberg, W. 2016 Atolls of the World: Revisiting the Original Checklist. Atoll Research Bulletin, 610:1-47.

Hedley, C. 1896. General Account of the Atoll of Funafuti. Memoirs of the Australian Museum, 3:1-71.

Index Mundi. 2014. Tuvalu demographics profile 2014. http://countrymeters.info/en/Tuvalu (accessed March 30, 2016).

Jackson, G. W. 2001. Tuvaluan Dictionary: Tuvaluan-English, English-Tuvaluan. Suva, Fiji: Oceania Printers.

Kayanne, H. 2009. “Eco-Technological Management of Tuvalu against Sea Level Rise.” Poster on University of Tokyo FORAM Sand Project, presented at the 2009 Climate Change Conference, Copenhagen, 7-18 December 2009.

Koch, G. [1961] 1983. The Material Culture of Tuvalu. Suva, Fiji: Institute of Pacific Studies, University of the South Pacific. Originally published as Die materielle culture der Ellice-Inselm (Berlin: Museum für Völkerkund).

—. 2002. "Plants for Humans - On Reef Islands in the Pacific: Niutao + Nonouti." Unpublished manuscript held by the Institute of Pacific Studies, University of the South Pacific, Suva.

Laracy, H., ed. 1983. Tuvalu: A History. Suva, Fiji and Funafuti, Tuvalu: Institute of Pacific Studies, University of the South Pacific and Ministry of Social Services, Government of Tuvalu.

Lennon, L. n.d. "Purslane - Portulacea umbraticola L.” ASLA Texas. http://c.ymcdn.com/sites/www.texasasla.org/resource/resmgr/docs/purslane.pdf (accessed March 30, 2016).

Maddison, P. A. 1989. UNDP/FAO-SPEC Survey of Agricultural Pests and Diseases in the South Pacific. Technical report, vol. 1. Auckland: Department of Scientific and Industrial Research.

Maiden, J. H. 1904. The Botany of Funafuti, Ellice Group. Proceedings of the Linnaean Society, 29:539-556.

Malaki, S., and R. North. 2015. "Tuvalu: Working Together to Recover in the Wake of Cyclone Pam.” International Federation of Red and Red Crescent Cross Societies. http://www.ifrc.org/en/news-andmedia/news-stories/asia-pacific/tuvalu/tuvalu-working-together-to-recover-in-the-wake-of-cyclonepam--68346/ (accessed March 30, 2016).

McLean, R. F. 2014. Recovery of Missing Explanatory Notes of the First Geological map of Funafuti Atoll, 1904. Atoll Research Bulletin, 603:1-11. 
Morrison, R. J. 1987. Chemistry and Classification of Pacific Low Atoll Soils. Alafua Agricultural Bulletin, 12(3):25-30.

Pacific Beat. 2015. “Tuvalu Battered by Heavy Rains, Strong Winds as Pacific Island Nations Brace for Cyclone Ula.” Australian Broadcasting Corporation Network. http://www.abc.net.au/news/2015-1231/pacific-island-nations-battered-by-heavy-rains-and-strong-winds/7061982 (accessed March 30, 2016).

The Plant List. 2013. Version 1.1. http://www.theplantlist.org/ (accessed October 13, 2016).

Rogers, K. A. 1991. A Brief History of Tuvalu’s Natural History. South Pacific Journal of Natural Science, 11:1-14.

Seluka, S. 1997. Traditional, Current and Potential Uses of Forests, Trees \& Other Plants of Tuvalu. Working Paper No. 9 (RAS/92/361). Suva, Fiji: South Pacific Forestry Development Programme.

Smith, R. 1995. Assessment of Lagoon Sand and Aggregate Resources, Funafuti Atoll, Tuvalu. SOPAC Technical Report 212. Suva, Fiji: Secretariat of the South Pacific Applied Geoscience Commission.

SOPAC. 2007. National Integrated Water Resource Management Diagnostic Report: Tuvalu. Draft SOPAC Miscellaneous Report 647. Suva, Fiji: South Pacific Applied Geoscience Commission. http://www.pacificwater.org/userfiles/file/GEF\%20IWRM\%20Final\%20Docs/sopac\%20Diagnostic\% 20Report\%20Tuvalu\%2022_10_07.pdf (accessed April 14, 2016).

Thaman, R. R. 1988. Health and Nutrition in the Pacific Islands: Development or Underdevelopment. GeoJournal, 16(2):211-227.

- 1992. Batiri kei Baravi: The Ethnobotany of Pacific Island Coastal Plants. Atoll Research Bulletin, 361:1-62.

- 1999. Wedelia trilobata—Daisy Invader of the Pacific Islands. IAS Technical Report 99/2. Suva, Fiji: Institute of Applied Science, University of the South Pacific.

. 2004. "Cool Spots under Threat: The Conservation Status of Atoll Biodiversity and EthnoBiodiversity in the Pacific Islands.” In Changing Islands - Changing Worlds: Proceedings of Islands of the World VIII, ed. K. J. Lee and H.-M. Tsai, pp. 60-64. Taipei: International Small Islands Studies Association (ISISA), National Taiwan Normal University.

— 2008. Atolls - The "Biodiversity Cool Spots" vs "Hot Spots": A Critical New Focus for Research and Conservation. Micronesica, 40(1/2):33-61.

- 2011. "Wedelia - Daisy Invader of Melanesia: The Worst Weed in the Pacific?” Melanesian Geo Magazine, May-August, pp. 6-12.

- 2014. Agrodeforestation and the Loss of Agrobiodiversity in the Pacific Islands: A Call for Conservation. In "Biodiversity Conservation in the Pacific Islands of Oceania," ed. S. Jupiter and R. Kingsford. Special issue, Pacific Conservation Biology, 20(2):188-192.

Thaman, R. R., and W. C. Clarke. 1993. "Pacific Island Agroforestry: Functional and Utilitarian Diversity.” In Pacific Island Agroforestry: Systems for Sustainability, ed. W. C. Clarke and R. R. Thaman, pp. 1733. Tokyo: United Nations University Press.

Thaman, R. R., E. Fihaki, and T. Fong. 2013. Plants of Tuvalu: Lākau mo mouku o Tuvalu. Suva, Fiji: University of the South Pacific Press.

Thaman, R. R., F. R. Fosberg, H. I. Manner, and D. C. Hassall. 1994. The Flora of Nauru. Atoll Research Bulletin, 392:1-223.

Thaman, R. R., D. C. Hassall, and S. Takeda. 2008. The Vegetation and Flora of Nauru: Current Status, Cultural Importance and Suggestions for Conservation, Restoration, Rehabilitation, Agroforestry and Food, Health and Economic Security. Suva, Fiji: Secretariat of the Pacific Community, Forests and Trees Programme.

Thaman, R. R., and G. Keppel. 2003. Vascular Plants and Vegetation of the Turtle Company Property, Wailoaloa, Nadi Bay, Ba Province, Viti Levu, Fiji Islands: A Preliminary Assessment. Botanical survey report prepared for Turtle Company. Suva, Fiji: South Pacific Regional Herbarium, University of the South Pacific.

Thaman, R. R., and U. Neemia. 1991. Tuvalu: National Report for the United Nations Conference on Environment and Development (UNCED), Rio de Janeiro, Brazil, June 1992. Noumea, New Caledonia: Office of the Prime Minister, Vaiaku, Funafuti, Tuvalu and South Pacific Regional Environment Programme (SPREP). 
Thaman, R. R., and K. O’Brien. 2011. Caterpillar Devastates kanava and Undermines Resilience to Climate Change in Tuvalu. Mai Life, 50(July):56-57.

Thaman, R. R., and W. A. Whistler. 1995. "Strategies for the Protection and Planting of Trees: A Preliminary Report of a Study of Uses, Husbandry and Performance of Trees in Forestry and Agroforestry Systems in Samoa, Tonga, Kiribati and Tuvalu.” In What Value Forests and Trees: Proceedings of Heads of Forestry Meeting 1993, 20-24 September, Nadi, Fiji, ed. H. T. Tang, L. S. Finiasi, and K. Enevoldsen, pp. 170-178. Field Document No. 6 (RAS/92/361). Suva, Fiji: South Pacific Forestry Development Programme.

-1996. A Review of Uses and Status of Trees and Forests in Land-Use Systems in Samoa, Tonga, Kiribati and Tuvalu with Recommendations for Future Action. Working Paper 5 (RAS/92/361). Suva, Fiji: South Pacific Forestry Development Programme.

Vula, T. 2011. "Serious on Tuvalu." Fiji Times, October 6, 2.

Whistler, W. A. 1980. Coastal Flowers of the Tropical Pacific. Lawai, Kauai, Hawaii: The Pacific Tropical Botanical Garden.

- 1991. Ethnobotany of Tonga: The Plants, Their Tongan Names, and Their Uses. Bishop Museum Bulletin in Botany 2. Honolulu: Bishop Museum Press.

-1992. Flowers of the Pacific Island Seashore: A Guide to the Littoral Plants of Hawaii, Tahiti, Samoa, Tonga, Cook Islands, Fiji and Micronesia. Honolulu: Isle Botanica.

- 1995. Wayside Plants of the Islands: A Guide to the Lowland Flora of the Pacific Islands

Including Hawai'i, Samoa, Tonga, Tahiti, Fiji, Guam and Belau. Honolulu: Isle Botanica.

- 2000a. Plants in Samoan Culture: The Ethnobotany of Samoa. Honolulu: Isle Botanica. . 2000b. Tropical Ornamentals: A Guide. Portland, Ore.: Timber Press.

- 2009. Plants of the Canoe People: An Ethnobotanical Voyage through Polynesia. Lawai, Kauai, Hawaii: National Tropical Botanical Garden.

Wiens, H. J. 1962. Atoll Environment and Ecology. Yale University Press, New Haven.

Wilkerson, D. C., and W. M. Johnson. n.d. "Tropical Hibiscus (Hibiscus rosa-sinensis) for Galveston County and the Texas Upper Gulf Coast.” AgriLife Gardening, Texas A\&M System. http://aggiehorticulture.tamu.edu/galveston/educ programs/Tropical-Hibiscus.pdf (accessed April 24, 2016).

Woodroffe, C. D. 1981. “Vegetation of Vaitupu, Tuvalu.” Tuvalu Land Resources Survey work-in-progress. Report 2. Unpublished.

- 1985. Vegetation and Flora of Nui Atoll, Tuvalu. Atoll Research Bulletin, 283:1-18.

- 1991. Vegetation of Tuvalu. South Pacific Journal of Natural Science, 11:82-128. 